Francisco José Alves

\title{
PRODUÇÃO E FORNECIMENTO DE VAPOR DE ETANOL PARA MOTOR DE COMBUSTÃO INTERNA OPERANDO COM COMBUSTÍVEL PRÉ-VAPORIZADO
}

Dissertação apresentada à Escola de Engenharia de São Carlos, da Universidade de São Paulo, como parte dos requisitos para obtenção do título de Mestre em Engenharia Mecânica.

Área de concentração: Engenharia Mecânica

Orientador: Prof. Dr. Josmar Dawilson Pagliuso

São Carlos

2007 



\section{Agradecimentos*}

A Deus, pela vida e pela sáude.

A meus pais, pela dedicação na criação e pelo investimento na oportunidade de estudo.

Ao Prof. Josmar pela disposição para me orientar.

Aos demais professores do Núcleo de Engenharia Térmica e Fluidos e ao Prof. Paulo Greco (Aeronáutica) pelos esclarecimentos eventualmente prestados.

Aos colegas de trabalho pelo companheirismo. Em especial a Sandro e Hélio pelo apoio técnico sem o qual não seria possível realizar o trabalho.

À Oficina Mecânica Auto Modelo e às indústrias KGM e Netgás, fornecedoras de kits para conversão para gás natural, pelas informações e assistência técnica prestadas.

Ao Grupo Virgolino Oliveira S/A Açúcar e Álcool, pelo combustível gentilmente doado.

Ao Laboratório de Desenvolvimento da Química do Aguardente (LDQA) do IQSC-USP, pela análise de espectroscopia de absorção de massa.

À oficina do Insituto de Física de São Carlos (IFSC-USP) pelo uso do jato de areia e pela confecção das janelas de vidro.

Aos desenvolvedores dos softwares livres (Linux, GIMP, Inkscape, OpenOffice, LTEX, Window Maker) que foram usados na realização do presente estudo.

\footnotetext{
*Este trabalho teve suporte financeiro da CAPES.
} 



\section{Sumário}

$\begin{array}{lc}\text { Lista de Figuras } & 8\end{array}$

Lista de Tabelas 9

Resumo 13

$\begin{array}{ll}\text { Abstract } & 14\end{array}$

1 Introdução 17

2 Revisão Bibliográfica $\quad 21$

2.1 Preocupação com a poluição do ar . . . . . . . . . . . . . . . . . . . 21

2.2 Desenvolvimento do motor movido a etanol hidratado . . . . . . . . . . . . . 25

2.3 Vantagens físicas da queima de combustíveis gasosos . . . . . . . . . . 31

2.4 Ebulição em superfícies externas ou pool boiling . . . . . . . . . . . . 33

3 Materiais e métodos 37

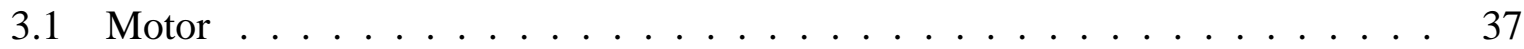

3.2 Produção de vapor . . . . . . . . . . . . . . . . . . . . 37

3.2 .1 Cálculo da área de troca térmica . . . . . . . . . . . . . . 39

3.2 .2 Perdas de carga . . . . . . . . . . . . . . . 42

3.3 Injeção de combustível . . . . . . . . . . . . . . . . . . . . . . 43

3.3 .1 Outros acessórios . . . . . . . . . . . . . . . . 44

3.3.2 Adaptações na válvula gaveta . . . . . . . . . . . . . . . . . 47

3.3.3 Dispositivo de sucção ou Venturi . . . . . . . . . . . . . . . . . . . . . 48

3.3.4 Resposta do sistema a variações na demanda de combustível . . . . . . 50

3.3.5 Controle da pressão de vapor . . . . . . . . . . . . . . 53

3.4 Outros aparatos experimentais $\ldots \ldots \ldots \ldots \ldots$

3.5 Configuração da bancada . . . . . . . . . . . . . . . . . . 55 
4 Resultados experimentais $\quad 59$

4.1 Sistema original de injeção . . . . . . . . . . . . . . . . . . . . . 59

4.2 Álcool vaporizado . . . . . . . . . . . . . . . . . . . . . . . . . . 59

4.3 Discussão . . . . . . . . . . . . . . . . . . . . . 66

4.3 .1 Marcha lenta . . . . . . . . . . . . . . . . 66

4.3.2 Regimes intermediários . . . . . . . . . . . . . . 67

4.3.3 Regimes de máxima potência . . . . . . . . . . . . . . 80

4.4 Aquecimento transiente . . . . . . . . . . . . . . . . . 81

5 Conclusões $\quad 87$

6 Sugestões para trabalhos futuros $\quad 89$

$\begin{array}{ll}\text { Referências } & 97\end{array}$

$\begin{array}{lll}\text { A Glossário } & 99\end{array}$

$\begin{array}{lll}\text { B Fórmulas utilizadas } & 101\end{array}$

B.1 Polinômio interpolador . . . . . . . . . . . . . . . . . . . . 101

B.2 Cálculo dos demais parâmetros . . . . . . . . . . . . . . 103

$\begin{array}{lll}\text { C Dados coletados } & 107\end{array}$

C.1 Aquecimento do motor . . . . . . . . . . . . . . . . . . . 107

C.2 Ensaios dinamométricos . . . . . . . . . . . . . . 111

D Desenhos técnicos 119 


\section{Lista de Figuras}

2.1 Ciclo Otto com diferentes tempos de combustão e refrigeração do cilindro durante a fase de compressão. . . . . . . . . . . . . . . . . 28

2.2 Simulação numérica do rendimento termodinâmico em função do avanço da centelha e do tempo de combustão. . . . . . . . . . . . . . . . . . . 29

2.3 Atraso de ignição para diversos combustíveis. . . . . . . . . . . . . . . . 32

2.4 Influência da pressão e da temperatura na flamabilidade . . . . . . . . . . . 33

2.5 Ebulição de água a 1 atm em superfície externa lisa Ni-Cr. . . . . . . . . . . 34

2.6 Calor transmitido na ebulição de diversos fluidos em função do superaquecimento. 36

3.1 Diagrama elétrico do retardador de sinal utilizado. . . . . . . . . . . . . . 47

3.2 Relação entre pressão, entalpia, entropia, volume específico e temperatura de saturação para etanol. . . . . . . . . . . . . . . . . 52

3.3 Diagrama elétrico do regulador de velocidade da ventoinha. . . . . . . . . . 54

3.4 Diagrama elétrico do ignorador de sinal. . . . . . . . . . . . . . 56

3.5 Disposição dos equipamentos. . . . . . . . . . . . . . 58

4.1 Emissões -2000 rpm e $23 \% \ldots \ldots \ldots \ldots \ldots$

4.2 Torque -2000 rpm e $23 \% \ldots \ldots \ldots \ldots \ldots$

4.3 Emissões específicas -2000rpm e $23 \% \ldots \ldots \ldots \ldots$. . . . . . . . 71

4.4 Emissões $-2000 \mathrm{rpm}$ e $453 \% \ldots \ldots \ldots \ldots \ldots \ldots$

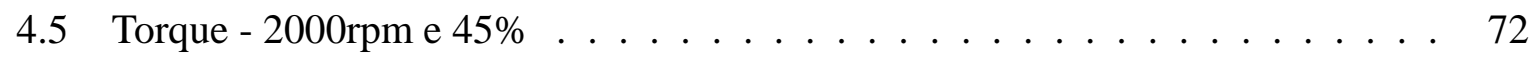

4.6 Emissões específicas - 2000rpm e 45\% . . . . . . . . . . . . . 72

4.7 Emissões $-3000 \mathrm{rpm}$ e $23 \% \ldots \ldots \ldots \ldots \ldots$

4.8 Torque -3000 rpm e $23 \% \ldots \ldots \ldots \ldots \ldots$

4.9 Emissões específicas - 3000rpm e 23\% . . . . . . . . . . . . . . 74

4.10 Emissões -3000 rpm e $45 \% \ldots \ldots \ldots \ldots$. . . . . . . . . . . . . . . .

4.11 Torque -3000 rpm e $45 \% \ldots \ldots \ldots \ldots$

4.12 Emissões específicas - 3000rpm e 45\% . . . . . . . . . . . 75

4.13 Emissões -4000 rpm e $23 \% \ldots \ldots \ldots \ldots$ 
4.14 Torque -4000 rpm e $23 \% \ldots \ldots \ldots \ldots$

4.15 Emissões específicas - 4000rpm e $23 \% \ldots \ldots$. . . . . . . . . 77

4.16 Emissões $-4000 \mathrm{rpm}$ e $45 \% \ldots \ldots \ldots 77$

4.17 Torque -4000 rpm e $45 \% \ldots \ldots \ldots \ldots \ldots$

4.18 Emissões específicas - 4000rpm e 45\% . . . . . . . . . . . . 78

4.19 Aquecimento da água e do óleo lubrificante, com a válvula termostática instalada. 84

4.20 Aquecimento da água e do óleo lubrificante, sem a válvula termostática instalada. 84

4.21 Evolução da pressão do etanol na caldeira, com e sem válvula termostática. . 85

B.1 Planilha eletrônica usada para interpolação de propriedades do etanol saturado. 102 


\section{Lista de Tabelas}

2.1 Emissões médias em veículos leves novos desde 1980. . . . . . . . . . . . . . 22

2.2 Limite de emissão de poluentes para veículos leves de passeio . . . . . . . . . 23

2.3 Limites estabelecidos para motocicletas pelo Promot . . . . . . . . . . . . 23

2.4 Calor latente e poder calorífico de alguns combustíveis . . . . . . . . . . 30

4.1 Produtos de combustão em base seca, com sistema de injeção original. . . . . . . 60

4.2 Produção/consumo específico com alimentação original . . . . . . . . . . . . . 60

4.3 Demais parâmetros calculados, referentes ao funcionamento do motor com ECU original. ............................... 61

4.4 Grandezas mecânicas e hidráulicas para os regimes operados com sistema de injeção de vapor de etanol. . . . . . . . . . . . . . . . . . . . . . . . . . 62

4.5 Emissões para etanol vaporizado. . . . . . . . . . . . . . . . . . . . . . . 64

4.6 Medidas de desempenho a 2000rpm e WOT com diversas combinações de razão ar-combustível e alimentação.

4.7 Medidas de desempenho a 3000rpm e WOT com diversas combinações de razão ar-combustível e alimentação.

B.1 Pressão de vapor do etanol em função da temperatura. . . . . . . . . . . . . 103

C.1 Ensaios de aquecimento transiente. . . . . . . . . . . . . . . . . . 107

C.2 Dados colhidos em ECU original (exceto consumo). . . . . . . . . . . . . . . 112

C.3 Consumo de combustível com ECU original. . . . . . . . . . . . . . . . . . 113

C.4 Medidas de pressão, consumo de combustível e de ar em diversos regimes de operação com combustível vaporizado. . . . . . . . . . . . . . . . . . . . . 114

C.5 Medidas de temperatura e emissões para diversos regimes, operando com etanol vaporizado. . . . . . . . . . . . . . . . . . 116

C.6 Ensaios adicionais com ECU original, para comparação de combinações torquerotação. . . . . . . . . . . . . . . . . . . . . . . 118 



\section{Lista de Símbolos}

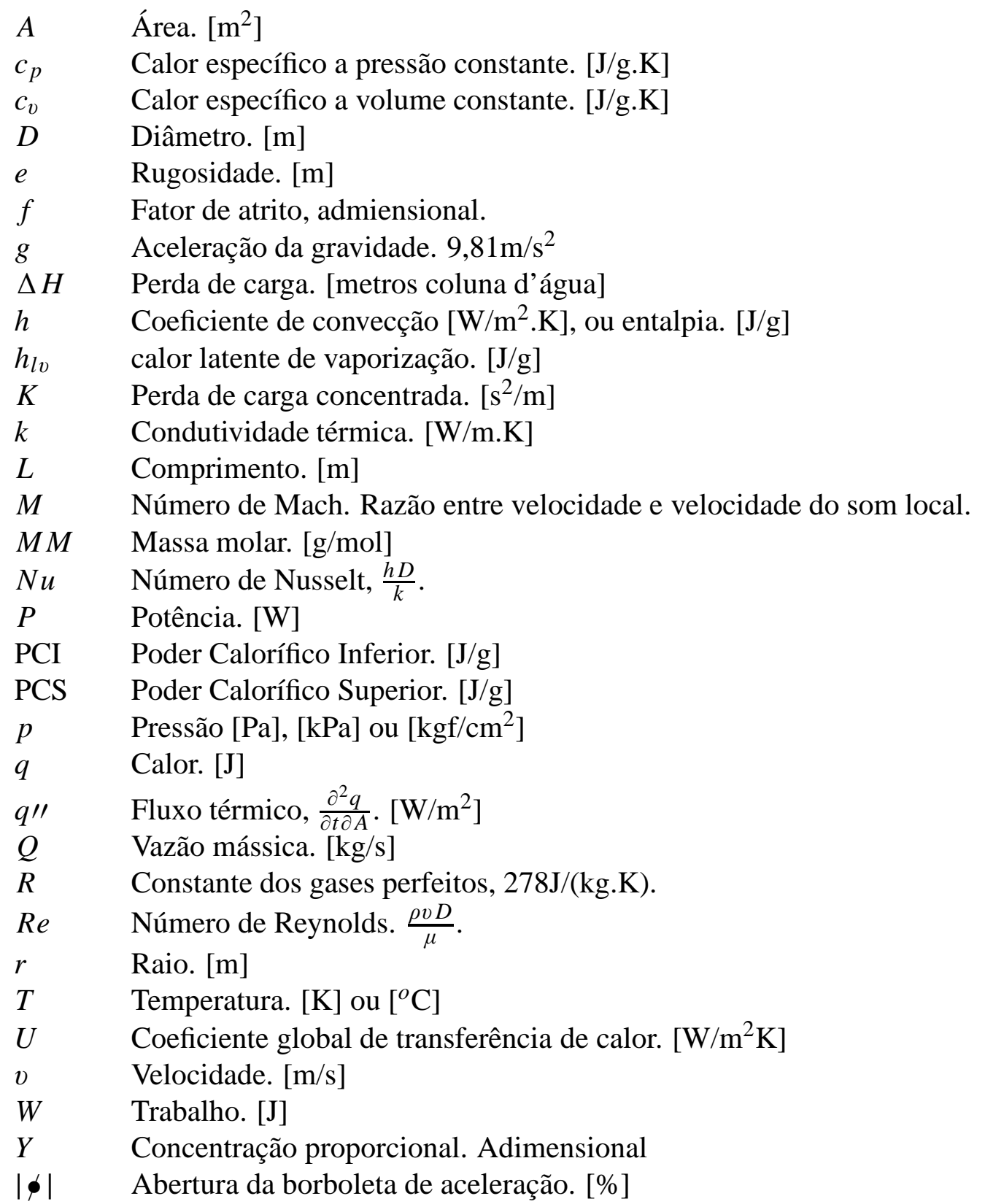




\section{Letras gregas}

$\gamma \quad$ Constante politrópica do ar. Razão entre calores específicos a pressão constante e a volume constante.

$\epsilon \quad$ Rugosidade adimensional. $\left[\frac{e}{D}\right]$

$\eta \quad$ Rendimento, adimensional.

$\Lambda \quad$ Razão mássica ar-combustível.

$\lambda \quad$ Razão ar-combustível em massa dividida pela razão estequiométrica. $\frac{\Lambda}{\Lambda_{\text {esteq }}}$

$\mu \quad$ Viscosidade. [N.s $\left./ \mathrm{m}^{2}\right]$

$\rho \quad$ Densidade. $\left[\mathrm{kg} / \mathrm{m}^{3}\right]$

$\tau \quad$ Torque $[\mathrm{Nm}]$

r Taxa de compressão, adimensional.

$\Omega \quad$ Resistência térmica, $\frac{\Delta T}{q^{\prime \prime}}$. $\left[\mathrm{K} /\left(\mathrm{m}^{2} \mathrm{~W}\right)\right]$ 


\section{Resumo}

ALVES, F.J. (2007) Produção e fornecimento de vapor de etanol para motor de combustão interna operando com combustível pré-vaporizado. Dissertação (Mestrado). Escola de Engenharia de São Carlos, Universidade de São Paulo, São Carlos-SP.

O motor a Álcool pré-vaporizado tem potencial para ser uma alternativa mais eficiente e menos poluente aos motores a álcool convencionais. Nele, o combustível é vaporizado com calor rejeitado pelo próprio motor e admitido na fase gasosa, aproveitando-se das vantagens dos motores com combustíveis nessa fase sem alguns dos seus inconvenientes. O projeto foi aperfeiçoado buscando viabilidade técnica e econômica para sua instalação em veículos automotores. Água do sistema de arrefecimento cede calor para a ebulição do combustível. As novas tecnologias para injeção de combustíveis gasosos contribuem para esse objetivo, bem como o desenvolvimento de um sistema sustentável e auto-ajustável de geração de vapor de etanol que usa a água do sistema de arrefecimento. Conseguiu-se maior eficiência em quase todos os regimes de funcionamento estudados, bem como meios de reduzir as principais emissões automotivas indesejáveis.

Palavras-chave: Combustíveis gasosos, energia renovável, injeção de combustível. 



\section{Abstract}

ALVES, F.J. (2007) Ethanol vapor production and feeding for an internal combustion engine operating with pre-vaporized fuel. Thesis (M. Sc.). São Carlos Engineering School, São Paulo University, São Carlos-SP.

Pre-vaporized ethanol engine (PVEE) has potential to be more efficient and less pollutant than conventional ethanol-powered engines. In it, fuel is vaporized with heat rejected by engine itself and intook in gaseous form, taking advantage of this kind of fuel but without some of its inconveniences. The PVEE project was polished looking for economical and technical liability to future use in automotive vehicles. New gaseous fuel injection technologies contribute to this goal, together the development of a sustainable and self-adjustable ethanol vapor generating system who uses water from engine's cooling system. Better efficiency was achieved in almost all investigated regimes, as well as were found ways to reduce the main undesirable automotive emissions.

Keywords: Gaseous fuels, renewable energy, fuel injection. 



\section{Capítulo 1}

\section{Introdução}

Após um período difícil para o Proálcool, que compreendeu o fim da década de 1980 e quase toda a década de 1990, o consumo desse combustível tem subido no País e volta a ser considerado seriamente como alternativa energética para os motores de combustão interna (MCI) ciclo Otto. Outras nações também cogitam incentivos ao uso do etanol em suas frotas, puro ou misturado à gasolina [1]. De acordo com relatório anual da Anfavea (Associação Nacional dos Fabricantes de Veículos Automotores) [2], a venda de veículos novos movidos a etanol foi multiplicada por 40 ente 1998 ("fundo do poço" para o Proálcool, quando chegou-se a comercializar kits de conversão para gasolina) e 2002. Os principais fatores que contribuiram para a elevação de seu prestígio são:

- Necessidade de adequação a acordos de redução de emissão de gases poluentes e/ou causadores de efeito estufa (ex. Protocolo de Kyoto). O uso de etanol, mesmo que parcial, diminui a responsabilidade dos participantes no aumento da concentração de gás carbônico na atmosfera, pois sendo o etanol uma fonte renovável de energia o gás emitido na sua combustão é reabsorvido durante o crescimento da cana. A preocupação com o efeito estufa intensificou-nos últimos anos, com o anúncio de graves alterações no clima do planeta e derretimento de calotas polares que causariam aumento no nível do mar e inundação de cidades litorâneas.

- Instabilidades políticas nas principais regiões fornecedores de petróleo, que aliada ao crescimento na sua demanda tem ajudado a elevar o preço desse insumo. Em movembro/2007 o preço do barril ultrapassou a marca de US\$100, forçando alta nos preços dos combustíveis fósseis em todo o mundo. Apesar das oscilações sazonais de preço devido ao seu ciclo de produção (safra), o preço do etanol mantém-se vantajoso economicamente ao longo do ano em relação à gasolina em várias regiões do País. Um aumento do preço desse último pode tornar essa vantagem mais flagrante. 
- Investimentos em infra-estrutura e logística para melhorar o transporte e a distribuição de etanol carburante tanto no mercado interno quanto para o exterior [3]. Portos, ampliação de hidrovias, terminais modais dedicados e até mesmo alcooldutos estão nos planos de empresas estatais e privadas para os próximos anos.

- Em fevereiro de 2007 o IPCC (Intergovernamental Panel on Climate Change, ou Painel Intergovernamental de Mudança Climática) publicou seu Quarto Relatório de Avaliação [4], mostrando resultados de estudos que dão confiabilidade à hipótese de que as alterações climáticas devem-se a interferências humanas, que elevaram a concentração de determinados gases na atmosfera, descartando a possibilidade de atribuí-las a causas naturais. Esse documento teve ampla divulgação e discussão na mídia em nível mundial; levando muitas pessoas, empresas e governos a refletir no assunto e buscar alternativas energéticas renováveis, entre elas o etanol combustível.

- Os acordos firmados com nações interessadas em comprar etanol brasileiro incentivam o compromisso por parte dos produtores em manter o fornecimento desse combustível estável e regular. Crises de abastecimento como a ocorrida em 1989 prejudicariam a imagem do Brasil e dos nosos produtores no exterior, bem como impediria a celebração de novos contratos comerciais envolvendo essa commodity.

- No Brasil o lançamento dos veículos flex fuel em 2003 permitiu que o consumidor passasse a ter a chance de escolher qual combustível usar sem precisar fazer alterações no motor. Apesar de não ser a alternativa mais eficiente do ponto de vista energético, tal configuração dá conforto psicológico ao proprietário do veículo, já que o povo brasileiro está de certa forma traumatizado com as falhas no suprimento de etanol em passado recente.

- Novas tecnologias que facilitam a partida a frio, impulsionadas pelo desenvolvimento das injeções eletrônicas. Já se pensa em sistemas totalmente independentes de reservatório de gasolina ou outro combustível, com foco na segurança (menor quantidade de reservatórios de combustível) e redução do custo de adaptações e novos projetos, já que a instalação de novos recipientes de combustível em um veículo exige que os fabricantes inutilizem muitos deles em crash tests.

- O petróleo não é renovável, o que significa que um dia não teremos mais essa fonte de energia e insumos para a indústria química. Estimativas prevêem duração entre 40 e 50 anos para as reservas mundiais de petróleo desde que sejam mantidos os padrões de crescimento do PIB e da população mundial [5]. Aparece, portanto, a preocupação em 
obter-se outra fonte de energia para os MCI-Otto que permita sua operação em condições semelhantes ou até melhores em relação à gasolina.

- Carvalho [6] aponta para um cenário em que a produção de etanol gera cerca de 150 vezes o número de empregos por quantidade de combustível produzido, em relação à gasolina.

Apesar da disseminação do uso de etanol misturado à gasolina, seja em quantia pré fixada (veículos brasileiros e num futuro próximo, de outros países) ou variável (flex-fuel); um motor que opere exclusivamente com álcool permite que o combustível seja admitido na forma vaporizada. Sendo substânica pura, sua ebulição acontece a temperatura constante, que depende da pressão, sem deixar resíduos. A gasolina, que é formada por dezenas de hidrocarbonetos, não permite isso; apenas evaporação parcial das suas frações mais leves.

O fato de ser substância pura, sem frações leves ou pesadas, também confere ao etanol vantagens como menores perdas evaporativas de combustível, que também são consideradas como poluição do ar, e a não formação de borras na câmara de combustão ou nos carburadores/injetores. A ausência no etanol de compostos aromáticos e de outros hidrocarbonetos característicos da gasolina também são favoráveis no sentido de emitir na atmosfera substâncias menos perigosas à saúde.

Um MCI-Otto operando com etanol pré-vaporizado pode obter vantagens em relação ao seu similar movido a etanol líquido; como menor emissão de poluentes e melhor rendimento termodinâmico. Há também, vantagens em se armazenar o combustível na forma líquida, vaporizá-lo na hora adequada e injetá-lo como vapor. Tais vantagens estão mais detalhadas no próximo capítulo.

Outro combustível renovável que surge como alternativa viável para alimentar MCIs é o 2,5dimetilfurano(2,5-DMF). Román-Leshkov et al. [7] descrevem uma rota de produção de 2,5DMF a partir da isomerização de biomassa, que pode tornar viável para os próximos anos a sua produção em larga escala a partir de outras matérias-primas vegetais. Há vantagens e desvantagens desse combustível em relação ao etanol. O 2,5-DMF tem poder calorífico e calor latente de vaporização semelhantes ao da gasolina, e por ser passível de síntese a partir de biomassa em geral pode vir a apresentar boa produtividade em relação à área agriculturável usada para obter suas matérias-primas; porém evapora-se a temperaturas mais altas que aquelas observadas para o etanol, para uma dada pressão. Não é solúvel em água, portanto não absorve umidade da atmosfera. O formato de sua molécula (um anel com um átomo de oxigênio e quatro de carbono, com grupo metil em dois deles) leva à suposição de que sua octanagem, ou resistência à auto-ignição, seja alta o suficiente para permitir uma taxa de compressão tão ou mais alta que aquela usada em um motor a gasolina. Em compensação o 2,5-DMF é tóxico e causaria 
maiores danos à saúde humana e ao meio ambiente em caso de vazamento, inalação ou ingestão acidentais.

Deve ficar claro que a adaptação para combustível vaporizado só é possível em motores flex fuel se os combustíveis ficarem em tanques separados; pois não pode haver gasolina misturada no circuito de produção de vapor em nenhuma hipótese. Os desnaturantes adicionados ao etanol carburante devem ter pressão de vapor maior que a do combustível em toda a faixa de temperatura em que ele trabalha, para evitar o acúmulo de substâncias menos voláteis nos componentes do sistema de geração de vapor. 


\section{Capítulo 2}

\section{Revisão Bibliográfica}

\subsection{Preocupação com a poluição do ar}

No passado, quando surgiram os motores de combustão interna, as pesquisas eram voltadas quase que exclusivamente para o aumento da potência. Após os choques do petróleo da década de 1970 a preocupação passou para o consumo de combustível. Atualmente o principal objetivo é controlar as emissões de gases poluentes dentro de níveis aceitáveis que não comprometam a qualidade de vida, especialmente em grandes metrópoles com muitos veículos automotores em circulação.

No Brasil, o Ibama (Instituto Brasileiro do Meio Ambiente e dos Recursos Naturais Renováveis) criou, em 1986, o Proconve (Programa para Controle das Emissões Veiculares), visando amenizar o impacto causado pelas emissões automotivas nas cidades brasileiras. Resultados significativos já foram alcançados desde sua implantação em 1986, como ilustra a tabela 2.1.

Os limites atuais e futuros para emissões estão na tabela 2.2. Nota-se que há restrições específicas para os veículos movidos a GNV, devido à importância que esse combustível conquistou no cenário nacional.

Outra categoria que ganhou muito espaço é a das motocicletas. De acrodo com a Abraciclo (Associação Brasileira dos Fabricantes de Motocicletas, Ciclomotores, Motonetas, Bicicletas e Similares) [9], a produção desse tipo de veículo no Brasil subiu de 83.458 unidades em 1993 para 1.057.333 em 2004, um aumento de $1167 \%$, o que significa que elas ganharam muita importância e participação na frota brasileira. O uso de misturas mais ricas e carburação na alimentação de seus motores, aliados à ausência de conversor catalítico na exaustão e ao crescimento vergtiginoso da frota são fatores que preocupam as autoridades ambientais. Para contornar o problema o Ibama criou em 2002 o Promot (Programa de Controle da Poluição do Ar por Motociclos, Ciclomotores e Similares) para estabelecer limites para as emissões desses veículos. Os limites atuais e previstos para entrar em vigor em 2009 estão detalhados na tabela 2.3. Para atender às exigências do Proconve os automóveis são dotados de conversores 
Tabela 2.1: Emissões médias em veículos leves novos desde 1980.

\begin{tabular}{|c|c|c|c|c|c|c|}
\hline Ano/modelo & Combustível & $\begin{array}{c}\mathrm{CO} \\
(\mathrm{g} / \mathrm{km})\end{array}$ & $\begin{array}{c}\text { THC } \\
(\mathrm{g} / \mathrm{km})\end{array}$ & $\begin{array}{c}\mathrm{NO}_{x} \\
(\mathrm{~g} / \mathrm{km})\end{array}$ & $\begin{array}{c}\text { Aldeídos } \\
(\mathrm{g} / \mathrm{km})\end{array}$ & $\begin{array}{c}\text { Emissões } \\
\text { evaporativas } \\
\text { (g/teste) }\end{array}$ \\
\hline Pré-1980 & Gasolina & 54 & 4,7 & 1,2 & 0,050 & $\mathrm{ND}^{\dagger}$ \\
\hline \multirow[t]{2}{*}{$1980-83$} & E22 & 33 & 3,0 & 1,4 & 0,050 & ND \\
\hline & Etanol & 18 & 1,6 & 1,0 & 0,160 & ND \\
\hline \multirow[t]{2}{*}{ 1984-85 } & E22 & 28,0 & 2,4 & 1,0 & 0,050 & 23,0 \\
\hline & Etanol & 16,9 & 1,6 & 1,6 & 0,180 & 10,0 \\
\hline \multirow[t]{2}{*}{$1986-87$} & E22 & 22,0 & 2,0 & 1,9 & 0,040 & 23,0 \\
\hline & Etanol & 16,0 & 1,6 & 1,8 & 0,110 & 10,0 \\
\hline \multirow[t]{2}{*}{1988} & E22 & 18,5 & 1,7 & 1,8 & 0,040 & 23,0 \\
\hline & Etanol & 13,3 & 1,7 & 1,4 & 0,110 & 10,0 \\
\hline \multirow[t]{2}{*}{1989} & E22 & $15,2(46 \%)^{\diamond}$ & $1,6(33 \%)$ & $1,6(0 \%)$ & $0,040(20 \%)$ & $23,0(0 \%)$ \\
\hline & Etanol & $12,8(24 \%)$ & $1,6(0 \%)$ & $1,1(8 \%)$ & $0,110(39 \%)$ & $10,0(0 \%)$ \\
\hline \multirow[t]{2}{*}{1990} & E22 & $13,3(53 \%)$ & $1,4(42 \%)$ & $1,4(13 \%)$ & $0,040(20 \%)$ & $2,7(88 \%)$ \\
\hline & Etanol & $10,8(36 \%)$ & $1,3(19 \%)$ & $1,2(0 \%)$ & $0,110(39 \%)$ & $1,8(82 \%)$ \\
\hline \multirow[t]{2}{*}{1991} & E22 & $11,5(59 \%)$ & $1,3(46 \%)$ & $1,3(19 \%)$ & $0,040(20 \%)$ & $2,7(88 \%)$ \\
\hline & Etanol & $8,4(50 \%)$ & $1,1(31 \%)$ & $1,0(17 \%)$ & $0,110(39 \%)$ & $1,8(82 \%)$ \\
\hline \multirow[t]{2}{*}{1992} & E22 & $6,2(78 \%)$ & $0,6(75 \%)$ & $0,6(63 \%)$ & $0,013(74 \%)$ & $2,0(91 \%)$ \\
\hline & Etanol & $3,6(79 \%)$ & $0,6(63 \%)$ & $0,5(58 \%)$ & $0,035(81 \%)$ & $0,9(91 \%)$ \\
\hline \multirow[t]{2}{*}{1993} & E22 & $6,3(77 \%)$ & $0,6(75 \%)$ & $0,8(50 \%)$ & $0,022(56 \%)$ & $1,7(03 \%)$ \\
\hline & Etanol & $4,2(75 \%)$ & $0,7(56 \%)$ & $0,6(50 \%)$ & $0,040(78 \%)$ & $1,1(89 \%)$ \\
\hline \multirow[t]{2}{*}{1994} & E22 & $6,0(79 \%)$ & $0,6(75 \%)$ & $0,7(56 \%)$ & $0,036(28 \%)$ & $1,6(93 \%)$ \\
\hline & Etanol & $4,6(73 \%)$ & $0,7(56 \%)$ & $0,7(42 \%)$ & $0,042(77 \%)$ & $0,9(91 \%)$ \\
\hline \multirow[t]{2}{*}{1995} & E22 & $4,7(83 \%)$ & $0,6(75 \%)$ & $0,6(62 \%)$ & $0,025(50 \%)$ & $1,6(93 \%)$ \\
\hline & Etanol & $4,6(73 \%)$ & $0,7(56 \%)$ & $0,7(42 \%)$ & $0,042(77 \%)$ & $0,9(91 \%)$ \\
\hline \multirow[t]{2}{*}{1996} & E22 & $3,8(86 \%)$ & $0,4(83 \%)$ & $0,5(69 \%)$ & $0,019(62 \%)$ & $1,2(95 \%)$ \\
\hline & Etanol & $3,9(77 \%)$ & $0,6(63 \%)$ & $0,7(42 \%)$ & $0,040(78 \%)$ & $0,8(92 \%)$ \\
\hline \multirow[t]{2}{*}{1997} & E22 & $1,2(96 \%)$ & $0,2(92 \%)$ & $0,3(81 \%)$ & $0,007(86 \%)$ & $1,0(96 \%)$ \\
\hline & Etanol & $0,9(95 \%)$ & $0,3(84 \%)$ & $0,3(75 \%)$ & $0,012(93 \%)$ & $1,1(89 \%)$ \\
\hline \multirow[t]{2}{*}{1998} & E22 & $0,8(97 \%)$ & $0,1(96 \%)$ & $0,2(88 \%)$ & $0,004(92 \%)$ & $0,8(97 \%)$ \\
\hline & Etanol & $0,7(96 \%)$ & $0,2(88 \%)$ & $0,2(83 \%)$ & $0,014(92 \%)$ & $1,3(87 \%)$ \\
\hline \multirow[t]{2}{*}{1999} & E22 & $0,7(98 \%)$ & $0,1(96 \%)$ & $0,2(88 \%)$ & $0,004(92 \%)$ & $0,8(97 \%)$ \\
\hline & Etanol & $0,6(96 \%)$ & $0,2(88 \%)$ & $0,2(83 \%)$ & $0,013(93 \%)$ & $1,6(84 \%)$ \\
\hline \multirow[t]{2}{*}{2000} & E22 & $0,73(97 \%)$ & $0,13(95 \%)$ & $0,21(87 \%)$ & $0,004(92 \%)$ & $0,73(97 \%)$ \\
\hline & Etanol & $0,63(96 \%)$ & $0,18(89 \%)$ & $0,21(83 \%)$ & $0,014(92 \%)$ & $1,35(87 \%)$ \\
\hline \multirow[t]{2}{*}{2001} & E22 & $0,48(98 \%)$ & $0,11(95 \%)$ & $0,14(91 \%)$ & $0,004(92 \%)$ & $0,68(97 \%)$ \\
\hline & Etanol & $0,66(96 \%)$ & $0,15(56 \%)$ & $0,08(93 \%)$ & $0,017(91 \%)$ & $1,31(87 \%)$ \\
\hline \multirow[t]{2}{*}{2002} & E22 & $0,43(98 \%)$ & $0,11(95 \%)$ & $0,12(95 \%)$ & $0,004(92 \%)$ & $0,61(97 \%)$ \\
\hline & Etanol & $0,74(96 \%)$ & $0,16(90 \%)$ & $0,08(93 \%)$ & $0,017(77 \%)$ & ND \\
\hline \multirow[t]{4}{*}{2003} & E22 & $0,4(98 \%)$ & $0,11(95 \%)$ & $0,12(93 \%)$ & $0,004(92 \%)$ & $0,75(97 \%)$ \\
\hline & Etanol & $0,77(95 \%)$ & $0,16(90 \%)$ & $0,09(93 \%)$ & $0,019(89 \%)$ & ND \\
\hline & Flex-E22 & $0,5(98 \%)$ & $0,05(98 \%)$ & $0,04(98 \%)$ & $0,004(92 \%)$ & ND \\
\hline & Flex-Etanol & $0,51(88 \%)$ & $0,15(90 \%)$ & $0,14(93 \%)$ & $0,020(89 \%)$ & ND \\
\hline
\end{tabular}


Conclusão

\begin{tabular}{|c|c|c|c|c|c|c|}
\hline 2004 & E22 & $0,35(99 \%)$ & $0,11(95 \%)$ & $0,09(94 \%)$ & $0,004(92 \%)$ & $0,69(97 \%)$ \\
& Etanol & $0,82(95 \%)$ & $0,17(89 \%)$ & $0,08(94 \%)$ & $0,016(91 \%)$ & ND \\
& Flex-E22 & $0,39(99 \%)$ & $0,08(97 \%)$ & $0,05(97 \%)$ & $0,003(94 \%)$ & ND \\
& Flex-Etanol & $0,46(97 \%)$ & $0,14(91 \%)$ & $0,14(91 \%)$ & $0,014(92 \%)$ & ND \\
\hline
\end{tabular}

$\dagger \mathrm{ND}=$ Não disponível

\$ E22=Mistura com $22 \%$ de etanol e $78 \%$ de gasolina.

$\diamond$ Redução de emissões em relação ao período pré-proconviano.

Fonte: Ibama [8].

Tabela 2.2: Limite de emissão de poluentes para veículos leves de passeio

\begin{tabular}{|l|c|c|c|}
\hline Poluentes: Limite máximo & $\begin{array}{c}\text { até } \\
31 / 12 / 2006\end{array}$ & $\begin{array}{c}\text { desde } \\
01 / 01 / 2005 \dagger\end{array}$ & $\begin{array}{c}\text { a partir de } \\
01 / 01 / 2009\end{array}$ \\
\hline Monóxido de carbono (CO, em g/Km) & 2,00 & 2,00 & 2,00 \\
\hline Hidrocarbonetos (HC, em g/Km) & 0,30 & $0,30^{\ddagger}$ & $0,30^{\ddagger}$ \\
\hline $\begin{array}{l}\text { Hidrocarbonetos exceto metano } \\
(\mathrm{NMHC}, \text { em g/Km) }\end{array}$ & $\mathrm{NE}^{\diamond}$ & 0,16 & 0,05 \\
\hline Óxidos de nitrogênio $\left(\mathrm{NO}_{x}, \mathrm{em} \mathrm{g/Km)}\right.$ & 0,60 & $0,25^{\S}$ ou $0,60^{\mathbb{q}}$ & $0,12^{\S}$ ou $0,25^{\mathbb{T}}$ \\
\hline Material particulado (MP, em g/Km) & 0,05 & 0,05 & 0,05 \\
\hline Aldeídos $(\mathrm{CHO}$, em g/Km) & 0,03 & 0,03 & 0,02 \\
\hline Emissões evaporativas (g/teste) & 2,00 & 2,00 & 2,00 \\
\hline Emissões pelo cárter & nula & nula & nula \\
\hline
\end{tabular}

$\dagger$ Exigência para 40\% dos veículos comercializados em 2005, 70\% em 2006 e 100\% em 2007.

\$ Apenas para veículos movidos a GNV.

$\S$ Veículos movidos a gasolina ou etanol.

II Veículos movidos a Diesel.

$\diamond$ Não exigível.

Fonte: Ibama [8].

Tabela 2.3: Limites estabelecidos para motocicletas pelo Promot

\begin{tabular}{|l|c|c|c|}
\hline & Motocicletas & Similares & Marcha lenta \\
\hline A partir de & $\mathrm{CO}: 6,0 \mathrm{~g} / \mathrm{km}$ & $\mathrm{CO}: 13,0 \mathrm{~g} / \mathrm{km}$ & $6,0 \% \mathrm{CO}$ vol. \\
& $\mathrm{HC}^{\mathrm{N}} \mathrm{NO}_{x}: 3,0 \mathrm{~g} / \mathrm{km}$ & $\mathrm{HC}: 3,00 \mathrm{~g} / \mathrm{km}$ & $\mathrm{cc}$ \\
& & $\mathrm{NO}_{x}: 0,3 \mathrm{~g} / \mathrm{km}$ & $\begin{array}{c}4,5 \% \mathrm{CO} \text { vol. } \\
\text { acima de } 250 \mathrm{cc}\end{array}$ \\
\hline Fabricado ou & $\mathrm{CO}: 5,5 \mathrm{~g} / \mathrm{km}$ & $\mathrm{CO}: 7,0 \mathrm{~g} / \mathrm{km}$ & idem \\
reconfigurado & $\mathrm{HC}: 1,2 \mathrm{~g} / \mathrm{km}$ & $\mathrm{HC}: 1,5 \mathrm{~g} / \mathrm{km}$ & \\
após & $1,0 \mathrm{~g} / \mathrm{km} \geq 150 \mathrm{cc}$ & $\mathrm{NO}_{x}: 0,4 \mathrm{~g} / \mathrm{km}$ & \\
$01 / 01 / 2005$ & $\mathrm{NO}_{x}: 0,3 \mathrm{~g} / \mathrm{km}$ & & \\
\hline \hline A partir de & Até $150 \mathrm{cc}$ & $\mathrm{Acima} \mathbf{d e} \mathbf{1 5 0 c c}$ & idem \\
$01 / 01 / 2009$ & $\mathrm{CO}: 2,0 \mathrm{~g} / \mathrm{km}$ & $\mathrm{CO}: 2,0 \mathrm{~g} / \mathrm{km}$ & \\
& $\mathrm{HC}: 0,8 \mathrm{~g} / \mathrm{km}$ & $\mathrm{HC}: 0,3 \mathrm{~g} / \mathrm{km}$ & \\
& $\mathrm{NO}_{x}: 0,15 \mathrm{~g} / \mathrm{m}$ & $\mathrm{NO}_{x}: 0,15 \mathrm{~g} / \mathrm{km}$ & \\
\hline
\end{tabular}

Fonte: Resoluções do $\operatorname{Ibama~}^{o}$ 297, (26/02/2002) e n ${ }^{o} 342$, (25/09/2003) [10, 11]. 
catalíticos (conhecidos simplesmente como catalisadores), que são dispositivos que agilizam algumas reações químicas que transformam os principais poluentes em substâncias menos perigosas. Os catalisadores, porém, apresentam alguns inconvenientes:

- Funcionam bem após um período de aquecimento. Durante essa fase a maioria das viagens curtas é realizada pelos motoristas e a mistura é geralmente rica para facilitar o funcionamento com o motor frio. Isso implica em baixa eficiência de conversão justamente quando ele é mais necessário. Há alternativas para contornar esse problema como o uso de peneiras moleculares que retêm oxigênio excedente quando a mistura for ligeiramente pobre ou ainda catalisadores isolados termicamente para armazenar o calor até o uso do veículo no dia seguinte. Brandt et al. [12] desenvolveram um modelo para estudar o comportamento transiente de catalisadores de três vias durante seu aquecimento e considerando o mecanismo de armazenagem de oxigênio possibilitado pelo óxido de cério, que corrige o efeito prejudicial de ligeiras variações na relação ar-combustível.

- O catalisador pode ser desativado ao longo de sua vida útil por razões térmicas ou químicas. A contaminação química é causada principalmente por enxofre e fósforo existentes na gasolina. A desativação térmica pode acontecer devido a funcionamento irregular que fornece ao catalisador temperaturas acima das admitidas pela sua estrutura. E tal dispositivo não é substituído quando é quebrado ou desativado devido ao seu alto preço.

- Os pequenos canais por onde passam os gases eliminados pelo motor causam perdas de carga que exigem mais energia para forçar sua passagem. De acordo com Martins [13] a perda de potência em um motor médio (em seus experimentos foi usado um motor de 2 litros de cilindrada) pode chegar a $24 \%$.

Há a expectativa de atender as exigências do Proconve com um MCI alimentado com etanol pré-vaporizado, operando sem catalisador. No MAPV há outra alternativa para controlar as emissões de poluentes regulamentadas pela lei brasileira: operar com misturas mais pobres. Os catalisadores de três vias utilizados atualmente precisam de uma relação ar-combustível muito próxima da estequiométrica para funcionar corretamente. Entende-se como funcionamento correto a oxidação dos combustíveis parcialmente queimados (CO e $\mathrm{HC}$ ) aliada à redução dos óxidos de nitrogênio $\left(\mathrm{NO}_{x}\right)$ formados.

Nos Estados Unidos a EPA (Environmental Protection Agency, ou Agência de Proteção Ambiental) recomenda o uso de combustíveis oxigenados, isto é, com um ou mais átomos de oxigênio em suas moléculas, misturados à gasolina para amenizar principalmente as emissões de CO. Os principais aditivos são o MTBE, etanol e metanol. O teor exigido na mistura é maior no inverno (mínimo de 2,7\% de oxigênio em peso), quando o efeito das emissões de CO na exaustão 
tornam-se mais graves. Tal recomendação baseia-se na lei estadunidense de poluição do ar, chamada Clean Air Act [14, 15].

Poulopoulos et al. [16] e Pau [17] estudaram a influência da mistura de etanol à gasolina nas emissões. Observa-se sensível redução nas emissões de CO e HC, lembrando que o maior calor latente do etanol atrasa sua evaporação em relação à gasolina, diminuindo os efeitos da presença de oxigênio sobre essas emissões e causando emissão de etanol não queimado e aldeídos.

A principal causa da emissão de CO é a queima incompleta de combustível, e aumenta rapidamente com enriquecimento de mistura carburante, conforme relatado por Hochgreb [18]. Combustíveis oxigenados como metanol e etanol facilitam o encontro com os átomos de oxigênio, facilitando conseqüentemente a oxidação.

\subsection{Desenvolvimento do motor movido a etanol hidratado}

O Laboratório de Motores da Escola de Engenharia de São Carlos contribui para o desenvolvimento do Motor a Álcool, pré-vaporizado ou não, desde os primórdios do Proálcool, na década de 1970.

Em estudos pioneiros de Celere [19] e Venanzi [20] já foi visto que uso de etanol vaporizado tem potencial para tornar o funcionamento de um MCI-Otto mais eficiente. Bergman [21] adaptou um motor originalmente designado para o ciclo Diesel, admitindo etanol vaporizado em conjunto com o Diesel da alimentação original. Obteve aumentos significativos no torque a baixas rotações, bem como diminuição nas emissões de poluentes em relação aos motores Diesel originais. Celere e Venanzi usaram resistências elétricas para evaporar o combustível, enquanto nos trabalhos de Bergman e D’Ávila [22, 23] já houve preocupação com o fornecimento auto-suficiente de energia para vaporização do combustível, através da água do sistema de arrefecimento ou dos gases de escape.

As principais vantagens possíveis de alcançar com o MAPV referem-se ao consumo específico e emissão de poluentes. A melhor tolerância desse combustível à operação com misturas pobres em relação aos combustíveis líquidos (menor relação combustvel-ar em relação à condição estequiométrica), aliada à presença de um átomo de oxigênio na sua molécula que diminui seu poder calorífico porém permite que se obtenha baixas emissões de monóxido de carbono $(\mathrm{CO})$ e hidrocarbonetos totais (THC) não queimados. Há em diversos países interesse em adicionar à gasolina combustíveis oxigenados como etanol, metanol ou Metil Terciário Butil Éter (MTBE) visando melhoras nas emissões de THC, CO e queda nas emissões evaporativas, que ficam em níveis comparáveis às de THC após combustão em veícuos antigos. O etanol tem a vantagem de não ser tóxico como os outros aditivos, exigindo menores cuidados em seu manuseio. 
As emissões evaporativas são perdas de combustível ocorridas antes que ele possa ser queimado, ainda no tanque de combustível e podem chegar a 50 gramas por dia por veículo em dias quentes, devido à oscilação na temperatura ao longo de um dia que faz com que ar entre e saia dos tanques, além da pressão de vapor das frações mais leves da gasolina [24]. Os veículos dotados de sistemas atuais de injeção eletrônica já contam com bocais de combustível herméticos e dispositivos que armazenam esses vapores em peças de carvão ativado (canister) para liberação posterior no coletor de admissão, levando-os à combustão.

Os óxidos de nitrogênio $\left(\mathrm{NO}_{x}\right)$ também podem ser controlados de acordo com a relação arcombustível, que tem efeito na temperatura máxima de chama, intimamente ligada às emissões desses compostos [18]. Há outros mecanismos formadores de $\mathrm{NO}_{x}$ não relacionados com a temperatura de chama, com menor participação nessas emissões [25].

Os combustíveis gasosos, como o gás natural veicular (GNV) ou gás liquefeito de petróleo (GLP) também oferecem a posibilidade de controle da temperatura de chama via relação arcombustível, mas têm inconvenientes de exigir tanques pesados, volumosos e equipamentos especiais de segurança.

A influência da relação ar-combustível nas emissões de poluentes em motores a gasolina foi investigada por Harrington e Shishu [26] apud [18]. Nota-se que misturas mais pobres favorecem o encontro das moléculas de combustível e comburente, diminuindo emissões de $\mathrm{CO}$ e $\mathrm{HC}$ até determinado ponto, apartir do qual a chama não propaga-se com a mesma estabilidade, causando falhas na combustão com conseqüente emissão de combustível parcialmente queimado. Misturas ligeiramente pobres, na faixa de $\lambda=1,1$ costumam atingir as máximas temperaturas, o que ajuda no rendimento termodinâmico porém é um inconveniente para o meio ambiente e a saúde pública devido às emissões de $\mathrm{NO}_{x}$. Misturas um pouco mais pobres, possíveis com combustíveis gasosos, diminuem a temperatura de chama e as emissões dessa categoria de poluente.

O etanol tem menor afinidade com o óleo lubrificante que os combustíveis formados por hidrocarbonetos, como a gasolina e o diesel. Isso diminui a contaminação do lubrificante, aumentando sua vida útil. Injetando-se álcool vaporizado o contato com o óleo lubrificante é ainda menor, pois evita-se o contato das gotas de combustível com a película de óleo existente nas paredes do cilindro.

Frestas nas câmaras de combustão e nas sedes dos anéis de pistão são grandes responsáveis por acúmulo de depósitos sólidos de combustível não queimado, de acordo com Hochgreb [18]. Tal fenônemo acontece principalmente devido à extinção de chama nessas regiões de difícil acesso e maior área de contato com as paredes que favorece transferência de calor. Motores a gasolina tendem a apresentar mais depósitos devido às frações mais pesadas em sua composição, en- 
quanto com etanol a densidade (e conseqüentemente a quantidade) do combustível localizado ali é menor, diminuindo as perdas de combustível e mantendo a câmara de combustão limpa. De acordo com Ferguson [27] os depósitos de combustível não queimado inicialmente formados nos motores a gasolina aumentam a área de contato entre superfície e gás dentro da câmara devido à sua porosidade, intensificando o fenômeno da extinção de chama e favorecendo a emissão de combustível não queimado (HC).

Em motores carburados ou mesmo com injeção indireta o uso de combustível gasoso pode trazer vantagens em regime transiente (aceleração). O transporte de combustível misturado ao ar é mais rápido do que se for feito através de arraste pelas paredes do coletor de admissão e/ou válvulas. A segunda modalidade é bem mais lenta, o que atrasa a chegada desse aos cilindros. Hohsho et al. [28] estudaram o comportamento de um motor carburado de 1,3 litros de cilindrada sob condições transientes de aceleração. Mudanças bruscas na abertura da borboleta de aceleração levaram a flutuações de torque e na rotação da árvore de manivelas, com uma ligeira queda após o início da aceleração. O responsável por isso é o atraso na chegada de combustível causado pela sua menor velocidade em relação à do ar. Hohsho et al. também realizaram ensaios no mesmo motor com aquecedores elétricos na parte inferior do coletor de admissão, onde verificou-se maior quantidade de combustível líquido arrastada pela corrente de ar. Conseguiuse menor flutuação no torque e eliminou-se a queda inicial na velocidade do virabrequim.

Pode-se ainda adotar uma mistura ligeiramente rica para compensar o empobrecimento dos momentos transientes de aceleração, com os inconvenientes de aumentar o consumo e a poluição decorrentes de operar um MCI nessas condições, conforme verificado por Ferguson [27], Sher [24], Cooper [29] e no caso do motor a álcool por da Silva [30].

A motocicleta Honda CB 500, fabricada no Brasil até meados de 2004, conta com um sistema de vaporização parcial de gasolina através de tubulações que circulam parte da água do sistema de arrefecimento nas cubas dos seus carburadores. Tal dispositivo confere ao veículo uma melhor resposta em acelerações e retomadas que concorrentes diretas suas na mesma faixa de potência e cilindrada, conforme averiguado pela revista Duas Rodas [31]. Nota-se que mesmo em motores de motocicletas, que costumam ter coletores de admissão curtos, qualquer vantagem visando um fluxo de combustível mais rápido através dele é bem vinda. Motores com injeção eletrônica indireta de combustível, mesmo que multiponto, também podem alcançar tais vantagens com combustíveis gasosos.

Uma consequência positiva de uma queima mais rápida é um ligeiro aumento no rendimento térmico. Num ciclo Otto ideal, o processo de adição de calor (queima da mistura) ocorre a volume constante. No ciclo real, o tempo de combustão é finito, durante o qual o pistão movimenta-se. Observando-se a figura 2.1 percebe-se que uma combustão mais demorada que 


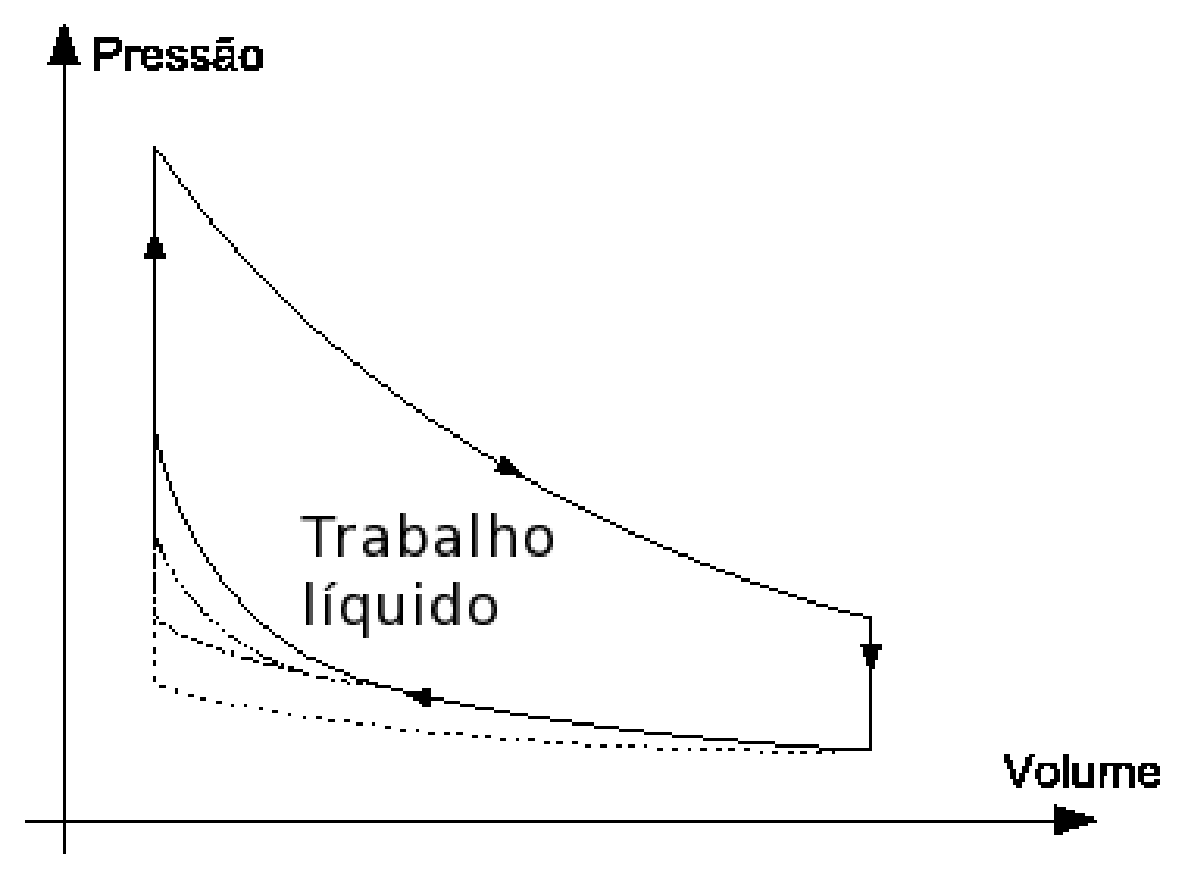

Figura 2.1: Ciclo Otto com diferentes tempos de combustão e refrigeração do cilindro durante a fase de compressão.

inicia mais cedo aumenta a pressão no cilindro durante a fase de compressão da mistura, o que aumenta o trabalho de compressão. Realizando a mesma quantidade de trabalho durante a expansão o trabalho líquido diminui, de acordo com as simulações realizadas por Ferguson [27]. Na figura, o estágio de compressão da mistura compreende quatro possibilidades diferentes: na linha superior, contínua, compressão da mistura em condições normais; a linha tracejada representa uma combustão mais rápida com atraso na centelha; a linha traço-e-ponto define uma combustão ideal com tempo tendendo a zero e portanto a volume constante. A linha inferior, pontilhada, representa uma combustão a volume constante com refrigeração prévia da mistura devido ao calor latente retirado do combustível durante sua evaporação dentro do cilindro. Nas três alternativas há uma redução do trabalho de compressão da mistura, implicando em melhor rendimento termodinâmico. A simulação feita por Ferguson [27] relacionando rendimento termodinâmico, tempo de combustão e atraso de ignição, cujo resultado está na figura 2.2, mostra as duas principais condições para que o máximo rendimento seja obtido: término da combustão exatamente quando o pistão encontra-se no ponto morto superior e menor tempo de combustão possível. Câmaras com mais de uma vela agilizam o processo, bem como sua disposição de forma adequada para que as frentes de chama percorram a câmara no menor intervalo possível. No caso a câmara de combustão hemisférica com vela no seu centro é a configuração mais favorável. O estudo de Souza [32] sobre os formatos de câmaras de combustão desde o surgimento dos MCI-Otto indica essa alternativa e completa dizendo que o uso 


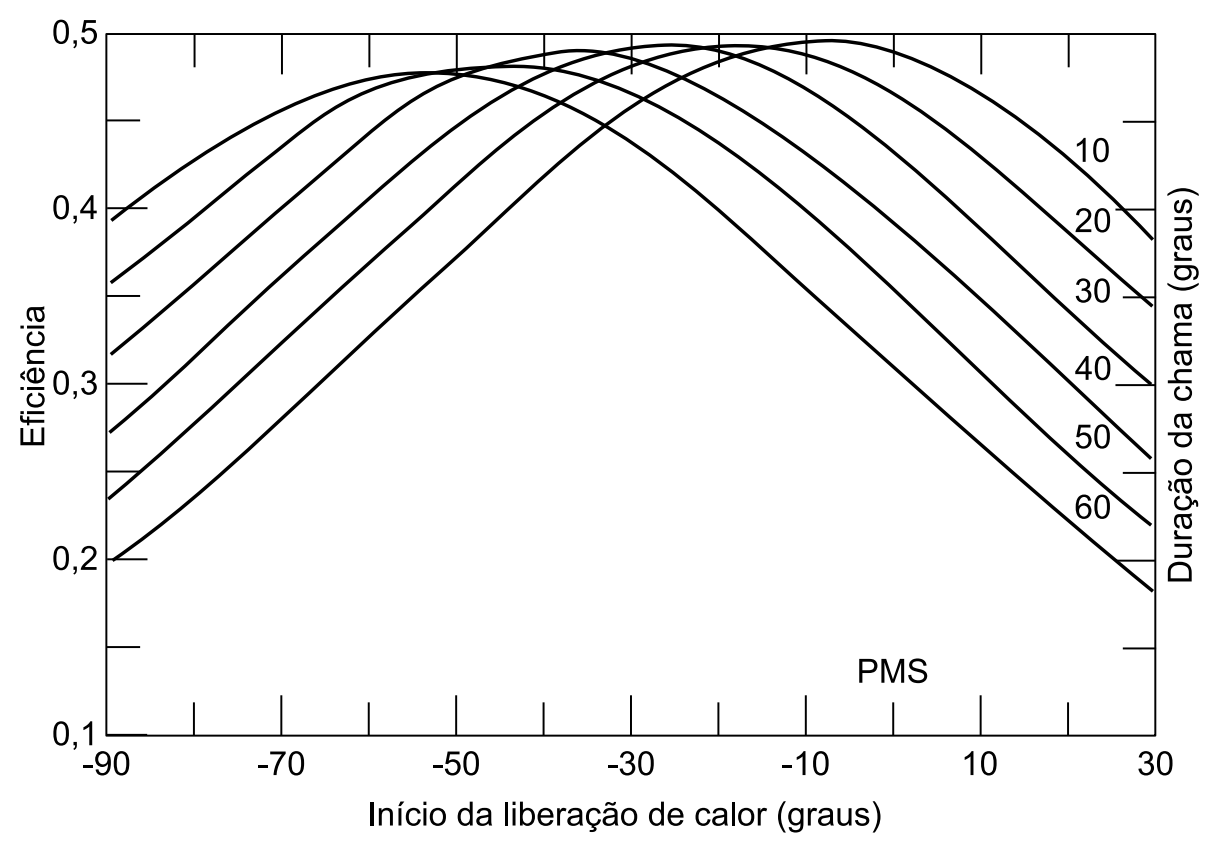

Figura 2.2: Simulação numérica do rendimento termodinâmico em função do avanço da centelha e do tempo de combustão.

Fonte: Ferguson [27].

de etanol pré-vaporizado dispensaria o uso de artefatos dentro ou fora da câmara de combustão que visem mistura e atomização do combustível, permitindo concentrar esforços na confecção de câmaras que evitem detonação, perda de calor e extinção de chama indesejáveis. Na prática, em motores convencionais o desempenho é um pouco sacrificado em favor da durabilidade com um ligeiro atraso na centelha, que diminui a pressão máxima na câmara.

Uma vantagem da injeção de combustíveis líquidos, especialmente álcoois como etanol e metanol, é a capacidade de retirar calor do ambiente durante sua evaporação, devido ao seus altos calores latentes. O calor necessário à evaporação desses combustíveis é retirado do ar no coletor de admissão e mesmo dentro do cilindro, aumentando sua densidade (melhorando o rendimento volumétrico) e diminuindo o trabalho necessário durante a fase de comppressão da mistura (figura 2.1). Tal fenômeno e sua influência no rendimento do motor foram estudados mais profundamente por Feitosa [33]. Sato et al. [34] estudaram a injeção de etanol e metanol em motores a jato ATREX (Air Turbo Ram-jet Engine Expander-cycle), visando refrigerar determinadas regiões. Esses combustíveis não são adequados para motores de propulsão devido aos seus poderes caloríficos baixos em relação ao dos combustíveis atualmente utilizados, como querosene ou hidrogênio. A vantagem consiste em injetar álcool em quantidades baixas em relação ao combustível principal (apoximadamente 3\%), para refrigerar o ar admitido antes de sua compressão, melhorando a eficiência do ciclo termodinâmico Brayton no qual opera a turbina. Tal método é mais barato e prático que resfriar o ar através de um trocador de calor, 
Tabela 2.4: Calor latente e poder calorífico de alguns combustíveis

\begin{tabular}{|l|c|c|c|c|c|}
\hline & $\begin{array}{c}\text { Metanol } \\
\left(\mathrm{CH}_{4} \mathrm{O}\right)\end{array}$ & $\begin{array}{c}\text { Etanol } \\
\left(\mathrm{C}_{2} \mathrm{H}_{6} \mathrm{O}\right)\end{array}$ & $\begin{array}{c}\text { Heptano } \\
\left(\mathrm{C}_{7} \mathrm{H}_{16}\right)\end{array}$ & $\begin{array}{c}2,2,4-\text { trimetilpentano } \\
\left(\mathrm{C}_{8} \mathrm{H}_{18}\right)\end{array}$ & $\begin{array}{c}\text { Metano } \\
\left(\mathrm{CH}_{4}\right)\end{array}$ \\
\hline $\mathrm{h}_{l v}(\mathrm{~J} / \mathrm{g})$ & 1180 & 1020 & 317,8 & 297,5 & - \\
\hline $\mathrm{PCS}(\mathrm{J} / \mathrm{g})$ & 21100 & 27710 & 44444 & 44350 & 56375 \\
\hline
\end{tabular}

Fonte: Gutheil [35] apud Feitosa [33] e Wikipedia [36].

que exige manutenção e forma gelo em sua superfície.

Souza [32], porém, adverte para a retirada indesejada de calor das paredes da câmara de combustão, que diminui suas temperaturas e favorece a extinção de chama e resfriamento indesejado da mistura logo após. No Brasil o uso de etanol é economicamente vantajoso em relação à gasolina. Essa tem maior poder calorífico inferior (PCI) que o etanol por unidade de massa: 40019J/g contra 26838J/g, de acordo com Taylor [37]. Usa-se o PCI na compração de poder energético devido ao fato dos gases deixarem a câmara de combustão a temperatura superior à de orvalho da água, impossibilitando a entrega de calor latente de condensação. Suas densidades são, respectivamente, $746 \mathrm{~kg} / \mathrm{m}^{3}$ e $735 \mathrm{~kg} / \mathrm{m}^{3}$, conforme [38]. É importante incluir a densidade no cálculo pois os combustíveis são vendidos por unidade de volume, não de massa. No caso, um litro de etanol tem mais massa que um litro de gasolina, influindo na quantidade de energia disponível.

Para definir o limite acima do qual o preço do etanol fica desvantajoso resta definir a eficiência termodinâmica teórica de um MCI-Otto de acordo com a taxa de compressão e fluido utilizado.

$$
\eta=1-\frac{1}{\mathbf{r}^{(\gamma-1)}}
$$

Pode-se assumir valores típicos de taxa de compressão (r) de 9:1 para motores a gasolina e 12:1 para os movidos a etanol hidratado. A razão de calores específicos para a mistura estequiométrica ar-etanol $(\gamma)$ vale 1,34 e para a mistura ar-isooctano vale 1,355 [37]. O rendimento teórico $(\eta)$ para cada configuração é:

$$
\begin{gathered}
\eta_{\text {etanol }}=1-\frac{1}{12^{(0,34)}}=0,5734 \\
\eta_{\text {gasolina }}=1-\frac{1}{9^{(0,355)}}=0,5416
\end{gathered}
$$

Com esses dados (PCI, densidade e rendimento teórico) o limite máximo da razão entre preços por litro que tornaria o uso de etanol inviável economicamente é:

$$
\frac{26838}{40019} \times \frac{0,5734}{0,5416} \times \frac{735}{746}=0,6995
$$

Ou seja, enquanto o preço do litro de etanol ficar abaixo de 69,95\% do preço do litro da gasolina ele é economicamente vantajoso nessas condições. 
A maior taxa de compressão é possível com etanol pois trata-se de um combustível mais resistente à detonação que a gasolina. Tal fenômeno é causado pela compressão dos gases não queimados pela expansão do gás já queimado dentro da câmara de combustão, que leva-os a temperaturas suficientemente altas para causar ignição espontânea antes da chegada da chama, com consequiências indesejáveis para o funcionamento do motor ciclo Otto. Com a detonação surgem picos de pressão que danificam o pistão e a câmara, causando ondas de choque com som característico. Moléculas mais curtas e ramificadas como a do etanol caracterizam combustíveis com maior resistência à ignição espontânea [25].

As ondas de choque criadas na detonação chegam a velocidades supersônicas (acima de $340 \mathrm{~m} / \mathrm{s}$ ), enquanto a velocidade de chama nos MCI-Otto é da ordem de dezenas de metros por segundo. De acordo com Souza [32], mesmo com combustíveis gasosos a velocidade de chama não chega a valores críticos (próximos à velocidade do som), não havendo risco de detonação. A maior velocidade de chama da mistura ar-etanol contribui para a chegada de chama aos locais mais distantes da vela antes que a mistura ali localizada atinja condições para auto-ignição. Warnatz et al. [25] descrevem mecanismos dependentes ou não da temperatura para auto-ignição a altas (da ordem de 1200K) e baixas (800-900K) temperaturas. Na queima combustíveis há um fenômeno chamado atraso de ignição (ignition delay) que durante determinado intervalo de tempo mantém reações que liberam pouco calor e consomem relatiavemente poucos radicais químicos. A partir de determinado instante a concentração desses radicais é suficiente para iniciar uma reação mais rápida, que leva a uma explosão/detonação. O tempo de atraso de ignição espontânea também depende da temperatura da mistura, como mostra a figura 2.3. Para determinada temperatura, nota-se que o etanol resiste à ignição espontânea por mais tempo que o n-heptano, e que esse resiste a determinado tempo de ignição a temperaturas mais baixas que as suportadas para o etanol nas mesmas condições.

\subsection{Vantagens físicas da queima de combustíveis gasosos}

A tolerância dos combustíveis gasosos a operação em uma faixa mais ampla de razão arcombustível talves possa permitir que o motor funcione com a borboleta totalmente aberta em algumas faixas de operação, passando a controlar o regime de funcionamento apenas com o fornecimento de combustível, semelhante aos motores Diesel, porém mantendo a ignição por centelha. Sem a necessidade de controlar a quantidade de ar admitido via borboleta ganharse-ia eficiência e rendimento volumétrico, já que há um obstáculo a menos para estrangular a passagem de ar. Esse objetivo foi buscado nos trabalhos anteriores envolvendo o MAPV [19, 21, 22, 23]. De acrodo com Strahle [39], misturas inflamáveis previamente homoge- 


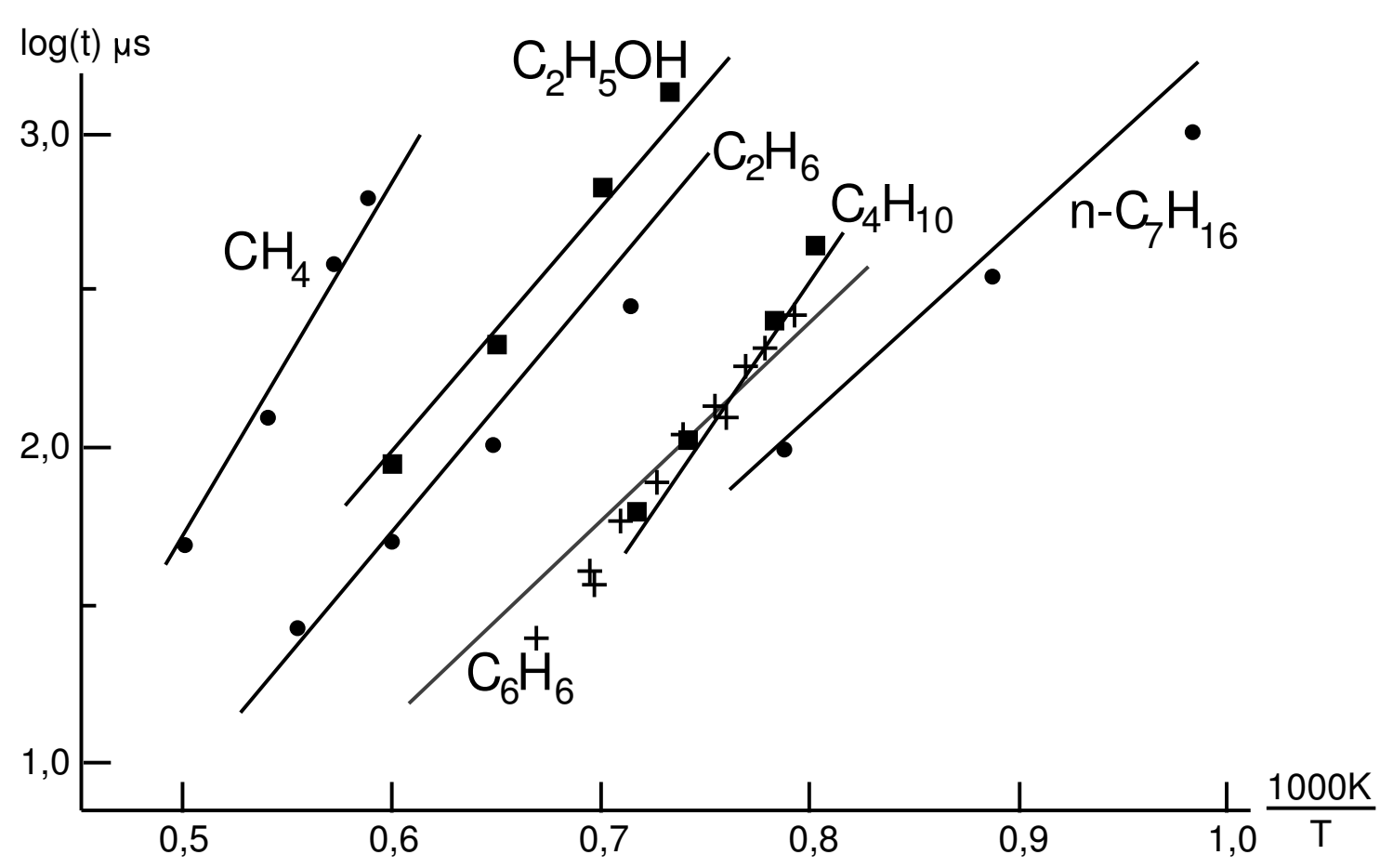

Figura 2.3: Atraso de ignição para diversos combustíveis.

Fonte: Warnatz et al. [25].

neizadas são capazes de manter uma chama estável para $\lambda$ entre 0,3 e 2,0 muma primeira aproximação, que pode mudar de acordo com o combustível. Os limites de flamabilidade dependem também da pressão e da temperatura em que a mistura se encontram no momento da ingnição, sendo favorecidos pelo aumento de qualquer um desses valores, conforme aponta Kanury [40]. Deve-se entretanto atentar para o fato de que a queima de mistura com $\lambda$ na cada de 1,1 causa altas temperaturas de chama, com reflexos nas emissões de óxidos de nitrogênio; nem em misturas pobres demais que comprometam a estabilidade da chama, causando altas emissões de combustível não queimado ou ainda menores velocidades de chama.

Misturas mais homogêneas queimam de forma mais rápida e completa. Admitindo-se combustível líquido que não entra na câmara totalmente vaporizado a chama precisa de mais tempo para consumi-lo todo, pois é necessário penetrar nas gotas, fornecer calor e vaporizá-las. De acordo com Warnatz et al. [25], esses fenômenos causam atrasos de ignição, que retardam o início da combustão de cada gota. A velocidade imprimida às gotas em relação ao ar na injeção de combustível contribui parcialmente para sua evaporação, pois favorece a conveção de calor e de massa; diminuindo seu diâmetro e diminuindo os inconvenientes das gotas maiores.

Experiências realizadas em ambiente de microgravidade na Estação Espacial Inernacional (ISS) por Kazakov et al. [41] aliadas a simulações computacionais também mostram que gotas de menor diâmetro queimam mais rapidamente que as de maior diâmetro, pois há a necessidade de 

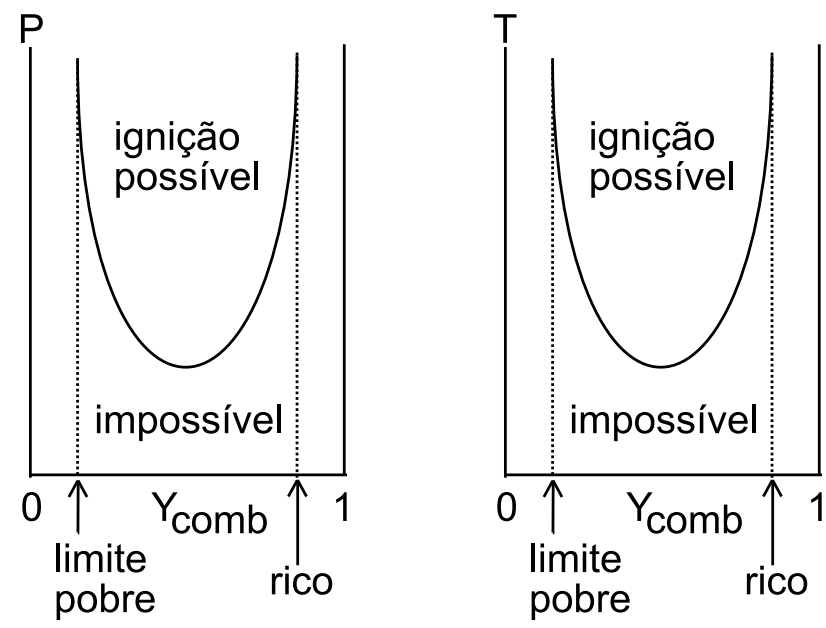

Figura 2.4: Influência da pressão e da temperatura da mistura fresca nos limites de flamabilidade, em função da concentração adimensional.

Fonte: Kanury [40].

aquecer a bolha de combustível e difundir o vapor do mesmo no ambiente com uma relação área/volume mais favorável no caso das bolhas menores.

Nesse tipo de experimento notou-se ainda a influência da umidade do ar no processo de transferência de calor e massa, graças à solubilidade do etanol em água. De acordo com Feitosa [33] e Kazakov et al. [41], a transferência de calor sensível e latente, após a chegada do vapor d'água ao ponto de orvalho, fornece calor que ajuda na evaporação do etanol. Porém em algumas condições onde a queima da mistura inflamável começa antes da total vaporização das gotas de combustível a concentração de água na periferia da gota pode dificultar a queima completa do etanol nela existente.

\subsection{Ebulição em superfícies externas ou pool boiling}

A transferência de calor com mudança de fase obedece a regras diferentes da transferência sem mudança de fase. A temperatura da superfície que transfere calor ao líquido em ebulição fica ligeiramente acima da temperatura de saturação do líquido, fornecendo um importante parâmetro chamado superaquecimento de parede. Outras propriedades como tensão superficial das bolhas, densidades do líquido e do vapor, calor latente, viscosidade, ângulo de contato líquido-sólido e acabamento da superfície determinam as condições em que se dá a transferência de calor no regime de mudança de fase $[42,43,44]$.

A figura 2.5 mostra os regimes de ebulição de água em superfície externa lisa (arame) de níquelcromo, de acordo com os experimentos de Nukiyama [45] apud Incropera [42]. A=início da 


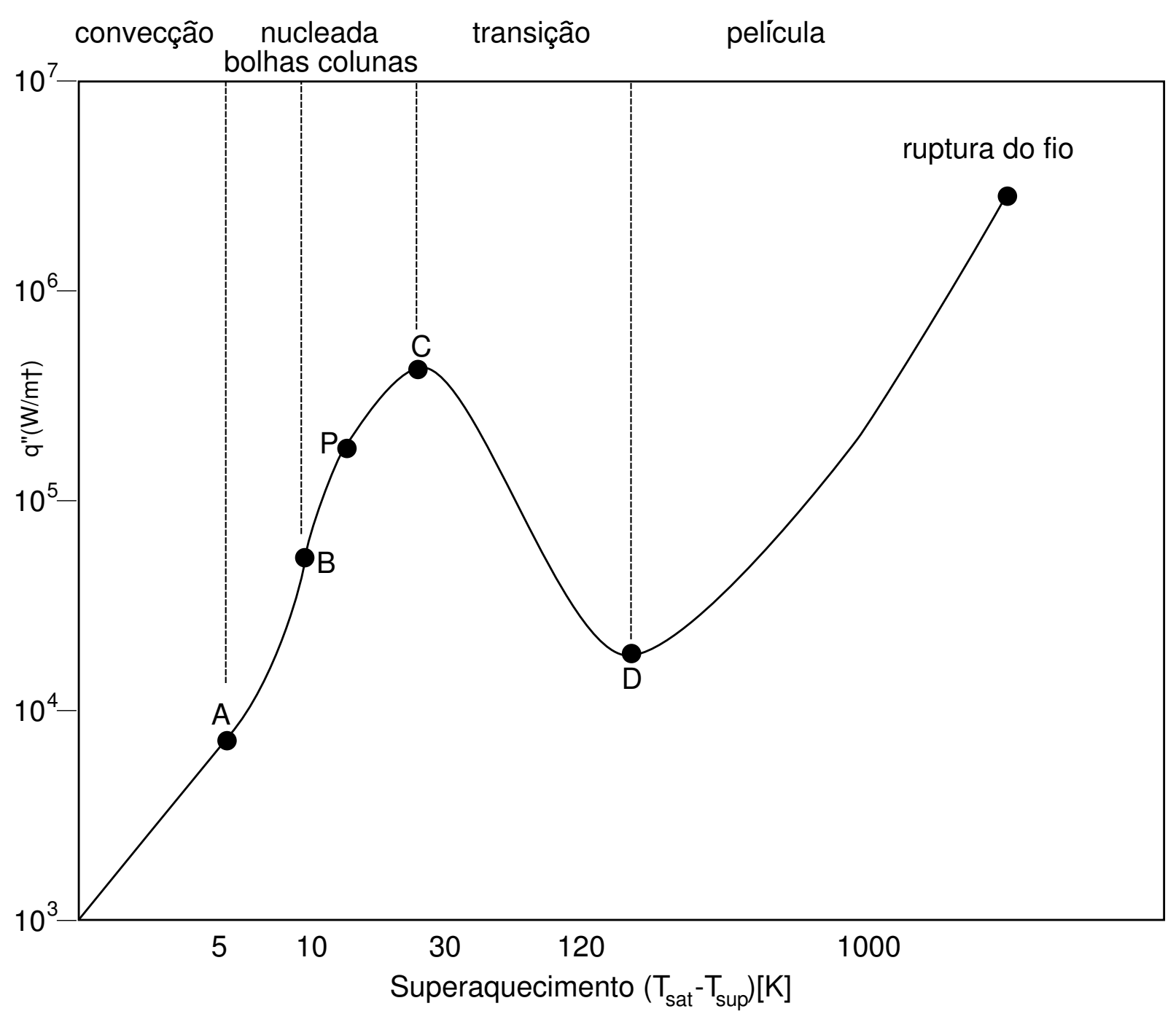

Figura 2.5: Ebulição de água a 1 atm em superfície externa lisa Ni-Cr.

Fonte: Nukiyama [45] apud Incropera [42].

ebulição; $\mathrm{B}=$ ausência de bolhas isoladas; $\mathrm{P}=$ máximo coeficiente de convecção $\left(h=\frac{\partial q^{\prime \prime}}{\partial \Delta T}\right)$; $\mathrm{C}=$ máximo fluxo de calor; $\mathrm{D}=$ mínimo fluxo, ponto de Leidenfrost.

Na ebulição da água, à medida em que aumenta-se o superaquecimento, o fluxo de calor começa como puramente convectivo. Após atingir-se determinada temperatura a ebulição inicia com bolhas isoladas. O desprendimento das bolhas movimenta o líquido nas adjacências, melhorando o coeficiene de transferência de calor. Acima do fluxo máximo de calor permitido (ponto P), passa-se para o regime de ebulição com película estável, onde uma camada de vapor envolve a superfície permanentemente, dificultando a troca térmica. Se o superaquecimento for controlado ao invés do fluxo de calor, há uma queda na fluxo (entre pontos P e D) marcando a transição para o regime de película estável. Aumentando o fluxo térmico ou o superaquecimento no regime de película estável atinge-se a temperatura de fusão do material, rompendo o fio no caso do experimento de Nukiyama [45] apud Incropera [42]. 
Existem tratamentos de superfície destinados a favorecer a transferência de calor com mudança de fase, diminuindo o superaquecimento requerido e/ou aumentando os coeficinentes de transferência de calor. Tratamentos de jato de areia, oxidação, microaletas, sinterização e microusinagem são utilizados. As pesquisas sobre superfícies especiais para ebulição privilegiam, entretanto, fluidos usados em sistemas frigoríficos, alguns hidrocarbonetos, oxigênio líquido, amônia e água. Há poucos estudos sobre evaporação de etanol, provavelmente porque há poucos processos onde precise-se de etanol na forma de vapor. Os estudos de Thome [44] ilustram a influência o fluxo de calor latente causada por parâmetros como material da superfície, tratamento de superfície, superaquecimento na parede e fluido utilizado. Também são discutidos o desenvolvimento dos vários tratamentos de superfície existentes e o superaquecimento mínimo para iniciar a ebulição.

Basicamente, as superfícies de ebulição podem ser alteradas de maneira macroscópica (aletadas) ou microscópica (abrasão, sinterização, oxidação). Nas superfícies microscopicamente estendidas há favorecimento na formação de bolhas devido à transmissão de calor a pequenas quantidades de líquido por superfícies relativamente maiores. Depois de iniciada a bolha tem mais facilidade para desenvolver-se até desprender-se da superfície. Para ebulição de etanol em superfícies externas, uma das relações existentes está na figura 2.6. Thome também determinou valores mínimos de superaquecimento para passar da condução de calor meramente convectiva para iniciar ebulição de etanol. Em superfícies lisas metálicas o superaquecimento necessário pode variar entre 6K e 23K. Superfícies "High Flux" (nome comercial para determinado tratamento de superfície de ebulição) garantem ebulição com 6K de superaquecimento. 


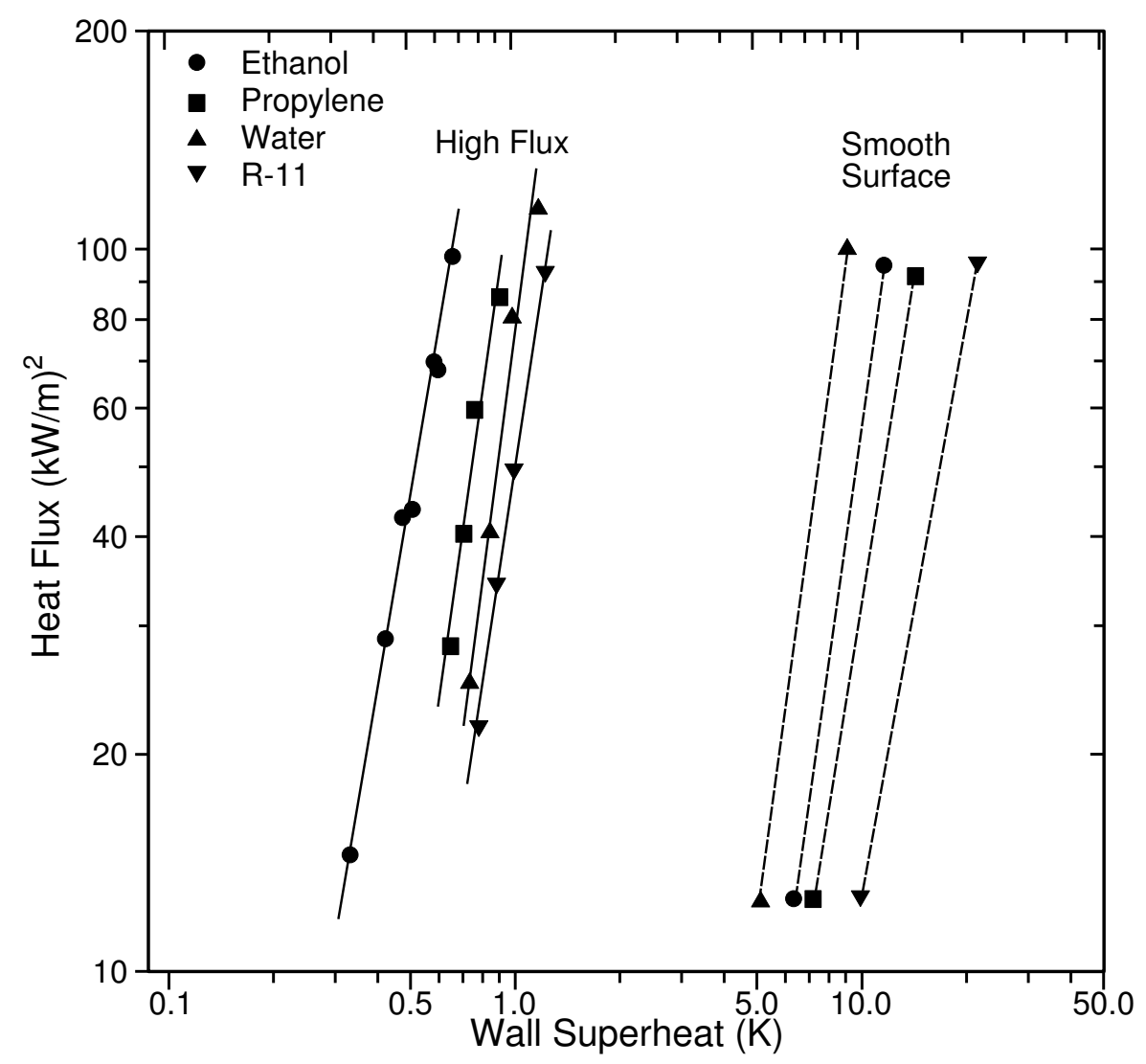

Figura 2.6: Calor transmitido na ebulição de diversos fluidos em função do superaquecimento. Fonte: Thome [44]. 


\section{Capítulo 3}

\section{Materiais e métodos}

\subsection{Motor}

Motor: Volkswagen AP, ciclo Otto, quatro cilindros em linha, refrigerado a água com circulação forçada, ano de fabricação 2001.

Diâmatero/curso: $67,1 \mathrm{~mm} / 70,6 \mathrm{~mm}$

Cilindrada: $999 \mathrm{~cm}^{3}$

Taxa de compressão original: 14,1:1[46]

Alimentação original: Etanol hidratado. Injeção indireta multipoint com gerenciamento eletrônico Bosch. As alterações no sistema de injeção estão descrita na seção 3.3.

Durante os ensaios o motor não estava equipado com filtro de ar nem conversor catalítico.

Diferenças de pressão atmosférica, umidade do ar e outras devidas às adaptações realizadas podem levar a diferentes índices de consumo, torque e emissões. Portanto não é apropriado comparar os resultados dos presentes ensaios com aqueles apresentados no manual do proprietário fornecido pelo fabricante do motor[46].

\subsection{Produção de vapor}

Há três alternativas para fornecer calor necessário à vaporização prévia de combustível num MCI: água do sistema de arrefecimento, gás de escape e óleo lubrificante. No trabalho de D’Ávila [23] foi usado o gás expelido pelo motor, aproveitando as altas temperaturas alcançadas para facilitar a transferência de calor. Esbarrou-se, porém, nos problemas da variação na temperatura e vazão desse gás que causaram instabilidades no fornecimento de vapor ao motor. Dependendo da configuração do trocador de calor, outro inconveniente possível é a vaporização repentina de grandes quantidades de combustível caso entre em contato com uma superfície que está a temperatura próxima à da exaustão dos gases queimados.

No presente estudo optou-se por usar a água do sistema de arrefecimento por operar em tem- 
peraturas mais baixas e sofrer menores variações. A menor temperatura de trabalho de água (oscilando próxima de um valor predeterminado) oferece uma diferença de temperatura mais estreita em relação ao combustível em ebulição, que é em parte compensada pelo seu maior calor específico em relação ao do ar. A vazão mássica de água é difícil de ser medida, e não há dados do fabricante da bomba d'água (Dana Corporation) a respeito.

Para projetar o trocador de calor, entretanto, admitiu-se que aproximadamente $1 / 3$ da energia contida no combustível é desperdiçada no sistema de arrefecimento. Também foi assumida uma queda de temperatura $(\Delta \mathrm{T})$ através do radiador de $10^{\circ} \mathrm{C}$. O poder calorífico inferior (PCI) do etanol vale aproximadamente $27700 \mathrm{~J} / \mathrm{g}$ A vazão de água $(\dot{q})$ no sistema de arrefecimento é dada por:

$$
\begin{gathered}
\dot{q}=\dot{Q}_{\text {agua }} c_{p} \Delta T_{\text {radiador }} \cong \frac{\dot{Q}_{\text {comb }} \times P C I}{3}=45690 \mathrm{~W} \\
\dot{Q}_{\text {agua }} \cong \frac{\dot{q}}{c_{p} \Delta T_{\text {radiador }}}=970 \mathrm{~g} / \mathrm{s}
\end{gathered}
$$

Onde $\dot{q}$ é a taxa de calor que a água do arrefecimento deve fornecer e $c_{p}$ é o calor específico da água ou do combustível em aquecimento. A área de troca de calor deve ser suficiente para fornecer a energia necessária à elevação da temperatura do combustível (calor sensível) e à ebulição (calor latente). Nos ensaios realizdos por D’Ávila no mesmo motor [23] o máximo consumo de combustível foi de 5,2g/s. Partindo o etanol de uma temperatura ambiente de $10^{\circ} \mathrm{C}$ até a ebulição a $82^{\circ} \mathrm{C}$ (correspondente à pressão de $120 \mathrm{kPa}$ ), a potência necessária é

$$
\dot{Q}\left[c_{p}\left(T_{e b}-T_{\text {entrada }}\right)+h_{l v}\right] \cong 5700 W
$$

Onde $h_{l v}$ representa o calor latente de vaporização do combustível. Dentro de determinados limites que não comprometam o funcionamento do motor nem o estado da água do arrefecimento, sua temperatura pode ser controlada regulando-se o termostato, também conhecido como "cebolão”. Admite-se para efeito de cálculo água na saída do motor a $96^{\circ} \mathrm{C}$ e combustível a até 82 extdegree $\mathrm{C}$, gerando uma diferença de temperatura de $14^{\circ} \mathrm{C}$. A temperatura da água deve variar pouco durante sua passagem pelo trocador em relação ao resfriamento obtido no radiador, já que o calor necessário à evaporação do etanol na situação de máxima potência e máximo consumo é de aproximadamente 1/8 do calor retirado via radiador. Tal variação na temperatura da água não prejudica a ebulição do combustível, como será visto postriormente.

Vários modelos de construção foram avaliados para o gerador de vapor. Os critérios principais foram: Possibilidade de colocá-lo no compartimento do motor de um veículo da mesma faixa de cilindrada; segurança; capacidade de atender rapidamente a alterações na demanda de combustível; facilidade de fabricação/manutenção e; evitar golpes de ariete no sistema de injeção. Mediu-se o espaço existente no compartimento do motor para alojar o gerador de vapor num 
automóvel que usa o mesmo motor utilizado, pensando em futuros testes de dirigibilidade, em condições mais próximas à realidade dos veículos de passeio.

O trocador de calor foi construído no modelo casco-tubo, com a água no lado interno e etanol na carcaça. Evaporar o combustível dentro dos tubos envolvidos pela água seria mais seguro e diminuiria agitações no combustível causadas por forças longitudinais e centrífugas que o veículo sofre durante seu movimento. Porém optou-se pela sua circulação pelo lado de fora dos tubos pela maior facilidade em aplicar-se o jato de areia e a lixação em superfícies externas, uma vez que esses tratamentos superficiais são importantes para a evaporação do combustível. O equipamento opera na posição vertical.

De acordo com as relações existentes para ebulição de etanol apresentadas do capítulo 2, a temperatura mínima de superaquecimento que permite ebulição de etanol em superfícies metálicas lisas pode variar de $6^{\circ} \mathrm{C}$ a $23^{\circ} \mathrm{C}$. Em superfícies com tratamento "High Flux" a ebulição já acontece com superaquecimento de $6^{\circ} \mathrm{C}$ [44]. No mesmo trabalho observa-se que a aplicação de jato de areia em superfície de cromo, técnica relativamente simples e barata, pode aumentar o coeficiente de transferência de calor em aproximadamente $25 \%$, e dobrá-lo com oxidação seguida de jato de areia. Nota-se que na figura 2.6 há poucos pontos de medição para a o fluxo de calor em função do superaquecimento, o que obriga a realizar um dimensionamento mais conservador. A superfície de ebulição do gerador de vapor usado neste trabalho foi lixada com lixa de granulometria "160", oxidada durante a soldagem do feixe de tubos com oxiacetileno, seguida de limpeza da camada de óxido em jato de areia. Tal tratamento seria mais difícil de realizar no lado interno dos tubos, daí a escolha pela ebulição do combustível pelo lado externo.

O espaço disponível para a instalação do gerador de vapor impõe uma distância entre a saída de vapor e sua admissão no Venturi. Para evitar risco de condensação foi confeccionado um tubo encamisado, ou seja, um tubo que conduz vapor protegido por outro tubo de maior diâmetro com água quente do sistema de arrefecimento. Esse tubo é ainda protegido poruma camada de espuma de poliuretano de aproximadamente $15 \mathrm{~mm}$ de espessura. Parte da água que circula pelo motor é destinada a essa tarefa e a de manter também o Venturi aquecido.

\subsubsection{Cálculo da área de troca térmica}

Para determinar um valor adequado de área de ebulição é necessário determinar os coeficientes de troca de calor em ambos os lados, no caso lado interno e exteno dos tubos, além do coeficiente de condução nos tubos. Não havendo mudança de fase é necessário também conhecer as vazões e os calores específicos dos fluidos em ambos os lados, para determinar a mudança de temperatura à medida em que eles avançam trocador adentro. No caso do gerador de vapor de etanol há mudança de fase (ebulição) em um dos lados e no outro há ligeira variação de tem- 
peratura que não será considerada. A temperatura da água do radiador sofre outras variações durante o funcionamento do motor e nesse caso o importante é ter uma estimativa conservadora da mínima diferença de temperatura alcançada e determinar se a superfície em contato com o combustível em ebulição (no caso a exterior) atinge o valor mínimo necessário em relação à temperatura de saturação (superaquecimento) que permita a sua evaporação.

O feixe foi confeccionado em cobre, com 48 tubos de diâmetro externo de 4,8mm (3/16"), diâmetro interno de $3,2 \mathrm{~mm}(1 / 8$ ”) e comprimento de $235 \mathrm{~mm}$. A área de troca térmica no lado externo, portanto, é de:

$$
0,00254 \times \frac{3}{16} \times 48 \times 2 \pi \times 0,235=0,3375 m^{2}
$$

Onde o fator 0,00254 converte polegada para metro. No lado interno, por onde passa a água do arrefecimento:

$$
0,00254 \times \frac{1}{8} \times 48 \times 2 \pi \times 0,235=0,2250 m^{2}
$$

A área da seção transversal por onde passa a água que fornece calor para a evaporação vale, para o feixe de 48 tubos com diâmetro interno de 1/8":

$$
A=48 \pi r^{2}=48 \pi\left(1,6.10^{3} m\right)^{2}=3,86.10^{-4} \mathrm{~m}^{2}
$$

Para o lado interno, sujeito a condução de calor com fluido a temperatura constante, o coeficiente de convecção, através dos números de Reynolds(Re) e Nusselt( $\mathrm{Nu})$, é calculado pela relação:

$$
\begin{gathered}
v=\frac{Q}{A \rho}=\frac{0,97}{3,86.10^{-4} \times 0,9615}=2,65 \mathrm{~m} / \mathrm{s} \\
\operatorname{Re}=\frac{\rho v D}{\mu}=\frac{961,5 \times 2,65 \times 3,175.10^{-3}}{2,89.10^{-4}}=27992 \\
N u=\frac{h D}{k}=0,023 \operatorname{Re}^{0,8} \operatorname{Pr}^{0,3}=0,023 \times 27992^{0,8} \times 1,80^{0,3}=99,07 \\
h=\frac{N u \cdot k}{D}=\frac{99,07 \times 0,679}{3,1785.10^{-3}}=21185 \mathrm{~W} / \mathrm{m}^{2} \mathrm{~K}
\end{gathered}
$$

Onde $v$ é a velocidade do fluido, A representa a área de troca térmica. $\rho$, a densidade; $k$, a condutividade térmica; $\mathrm{D}$, o diâmetro e as propriedades da água a $370 \mathrm{~K}\left(96,85^{\circ} \mathrm{C}\right)$ são utilizadas. A resistência térmica dos tubos de cobre $\left(\Omega_{C u}\right.$ vale:

$$
\Omega_{C u}=\frac{\ln \left(r_{2} / r_{1}\right)}{2 \pi k_{C u} L}=\frac{\ln (0,0047625 / 0,0031785)}{6,2832 \times 397 \times 0,235}=6,917.10^{-4} \mathrm{~m}^{2} \mathrm{~K} / \mathrm{W}
$$

Faltando determinar o coeficiente de troca térmica no lado externo dos tubos, onde há ebulição. Para um trocador de calor, o coeficiente global de transmissão de calor (U) vale:

$$
U=\frac{1}{\frac{D_{i}}{D_{e}} \frac{1}{h_{i n t}}+\Omega_{C u}+\frac{1}{h_{e x t}}}
$$


No trocador em questão, no regime de máxima potência do motor exige-se uma transmissão de calor a taxa de 5700W. Sendo sua área de troca igual a $0,3376 \mathrm{~m}^{2}$, o fluxo máximo de calor é:

$$
q^{\prime \prime}=\frac{5700 W}{0,3376 m^{2}}=16886 \frac{W}{m^{2}}
$$

Com uma diferença de temperatura entre os fluidos estimada em 14K, o coeficiente mínimo de troca térmica deve ser de:

$$
U_{\min }=\frac{q^{\prime \prime}}{\Delta T}=1206 \frac{W}{m^{2} K}
$$

Para que esse valor seja atingido $h_{\text {ext }}$ deve ter um valor mínimo, calculado com as seguintes condições:

$$
\begin{gathered}
1206=\frac{1}{\frac{D_{i}}{D_{e}} \frac{1}{21185}+1,441.10^{-5}+\frac{1}{h_{\text {ext }}}} \\
1206\left(4,5879.10^{-5}+\frac{1}{h_{\text {ext }}}\right)=1 \\
5,5221.10^{-2}+\frac{1206}{h_{\text {ext }}}=1 \\
\frac{1206}{h_{\text {ext }}}=0,944779 \\
h_{\text {ext }, \text { min }}=\frac{1206}{0,944779}=1276,5 \frac{\mathrm{W}}{\mathrm{m}^{2} \mathrm{~K}}
\end{gathered}
$$

Pela proximidade entre os valores do coeficiente mínimo de conveção no lado externo e o coeficiente global mínimo exigido percebe-se que as resistências térmicas da parede dos tubos e do lado interno têm pouca importância. Havendo o coeficiente mínimo necessário na superfície externa, a diferença de temperatura entre o fluido e a parede (superaquecimento) vale:

$$
\frac{q^{\prime \prime}}{h_{\text {ext }}}=\frac{16886 \mathrm{~W} / \mathrm{m}^{2}}{1276,5 \mathrm{~W} / \mathrm{m}^{2} \mathrm{~K}}=13,07 \mathrm{~K}
$$

Valor suficiente para promover a ebulição, de acordo com a figura 2.6. Usando-se método de tentativa e erro, o coeficiente de convecção e o superaquecimento convergirão de forma a adequar-se às relações determinadas pelo tratamento de superfície e ao fluido em ebulição.

A vibração no veículo causada pelo motor favorece a ebulição por ajudar no desprendimento das bolhas liberando a superfície aquecida para transmitir calor para novas porções de líquido, com maior coeficiente de convecção. Lee et al. [47] estudaram a influência de vibrações na troca de calor com mudança de fase, chegando a sugerir métodos para calcular múmeros de Reynolds e Nusselt vibracionais em função da frequiência e amplitude das vibrações. Esses parâmetros não foram calculados por exigir medidas de vibrações na carroceria do veículo ou na bancada, mas fica registrado que há uma influência positiva na evaporação do combustível. 


\subsubsection{Perdas de carga}

A curva de operação da bomba d'água não é conhecida, tampouco o comportamento hidráulico das cavidades do motor por onde ela passa. Foi estimada apenas a perda de carga nas mangueiras e principalmente no gerador de vapor, para avaliar o impacto de sua instalação no sistema. Os cálculos referem-se à estimativa de vazão máxima (cerca de $1 \mathrm{~kg} / \mathrm{s}$ ), podendo admitir-se perda de carga porporcional ao quadrado da vazão.

Com número de Reynolds estimado anteriormente em 27992, acabamento superficial de tubos de cobre extrudido (rugosidade adimensional $\epsilon=\frac{e}{D} \cong 2,410^{-4}$ ), que leva a um fator de atrito (f) de 0,023 ; a perda de carga $(\Delta \mathrm{H})$ neles vale, de acordo com o comprimento L de cada tubo:

$$
\Delta H_{\text {feixe }}=f \frac{L}{D} \frac{v^{2}}{2}=0,023 \frac{2,3510^{-1}}{3,210^{-3}} \frac{2,59^{2}}{2}=5,665 \mathrm{mca}
$$

Nas expansões de entrada e saída do evaporador, onde os diâmetros são, respectivamente 31,75$\mathrm{mm}(1,25$ ”), $28 \mathrm{~mm}$ e $108 \mathrm{~mm}$ na entrada e têm a ordem inversa na saída. Os coeficientes de perda localizada (K) são, de 0,06 na redução $31,75 \mathrm{~mm}-28 \mathrm{~mm}$ e na expansão $28 \mathrm{~mm}-31,75 \mathrm{~mm}$. A redução de diâmero de $108 \mathrm{~mm}$ para $28 \mathrm{~mm}$ tem coeficiente de aproximadamente 0,46 e a expansão recíprocra, 0,86. Tais dados foram coletados em [48].

$$
\begin{gathered}
\Delta H_{1,25^{\prime \prime}-28}=K_{1,25^{\prime \prime}-28} \frac{v^{2}}{2}=0,2 m c a \\
\Delta H_{28-1,25^{\prime \prime}}=K_{28-1,25^{\prime \prime}} \frac{v^{2}}{2}=0,2 m c a \\
\Delta H_{108-28}=K_{108-28} \frac{v^{2}}{2}=2,88 m c a \\
\Delta H_{28-108}=K_{28-108} \frac{v^{2}}{2}=1,54 m c a
\end{gathered}
$$

Uma conexão com $28 \mathrm{~mm}$ de diâmetro interno liga duas seções da mangueira entre a saída do gerador e o radiador:

$$
\Delta H_{\text {conexão }}=2 K \frac{v^{2}}{2}=2 \times 0,06 \times \frac{1,62^{2}}{2}=0,15 m c a
$$

E finalmente a perda de carga causada pela entrada de água nos tubos de 3,2mm de diâmetro a partir da câmara com 128mm de diâmetro, considerada um reservatório infinito. Para saída de água a perda de carga é semelhante.

$$
K=0,5 \longrightarrow \Delta H_{\text {ent } / \text { sai }}=0,5 \frac{2,59^{2}}{2}=1,67 m c a
$$

A perda de carga total, desconsiderando as perdas distribuídas ao longo das conexões, é dada por:

$$
\Delta H=\sum_{i} \Delta H_{i} \frac{v^{2}}{2}=(0,06+0,86+0,46+0,06+2.0,5+2.0,06) \frac{1.62^{2}}{2}
$$




$$
\Delta H=3,22 m c a
$$

Somando-se às perdas distribuídas do feixe de tubos totalizam 8,88mca. Para uma vazão de $1 \mathrm{~kg} / \mathrm{s}$ essa perda de carga exige uma potência adicional de bombeamento estimada em

$$
P_{\text {bomb }}=\Delta H \rho g Q=8,88 m \times 10^{3} \frac{\mathrm{kg}}{\mathrm{m}^{3}} \times 9,81 \frac{\mathrm{m}}{\mathrm{s}^{2}} \times 10^{-3} \frac{\mathrm{m}^{3}}{\mathrm{~s}}=87 \mathrm{~W}
$$

que é proporcional ao cubo da vazão.

\subsection{Injeção de combustível}

O sistema original de injeção de combustível foi substituído pela injeção eletrônica programável em tempo real marca Fueltech, modelo RacePRO-1Fi. Com ela pode-se alterar parâmetros como tempo de abertura dos bicos injetores e ângulo de ignição com o motor em funcionamento. Dessa forma é possível alterar o momento de disparo da centelha sem a necessidade de rodar a carcaça do distribuidor e ler os dados fornecidos pela pistola estroboscópica ao mesmo tempo. O controle do tempo de ignição também foi usado para operar o motor em condições próximas às definidas no seu módulo original para permitir comparações entre o etanol líquido e o vaporizado.

Também foram usadas partes do kit de conversão para gás natural Netgás/KGM GMS-7 versão 5.0. O cilindro para armazenar gás e o redutor de pressão não são necessários no presente estudo.

A admissão de combustível vaporizado foi feita com um sistema semelhante à carburação a gás usada nos trabalhos anteriores de D'Ávila [22, 23] e Celere [19]. A principal diferença fica por conta de avanços tecnológicos no equipamento utilizado.

A frota de veículos movidos a GNV no Brasil tem aumentado muito nos últimos anos, devido à competitividade dessa fonte energética que permite uma redução de custo de até $50 \%$ por distância percorrida em relação à gasolina. A disseminação de kits para conversão para GNV sem cuidados com o consumo e principalmente as emissões de poluentes forçou o Conama (Conselho Nacional de Meio Ambiente) a estipular limites a partir de 2002 [49]. As emissões de metano, etanal (acetaldeído) e metanal (formaldeído) são as principais nos veículos que operam com esse combustível.

Os kits mais antigos contam com uma válvula entre o redutor de pressão e o dispositivo de sucção (também conhecido como Venturi), regulada no final da instalação apenas com a experiência do profissional da oficina mecânica, método conhecido popularmente como regulagem "de ouvido". O ajuste dessa válvula é feito com o motor em ponto morto a aproximadamente 3000rpm, caso o veículo não conte com um tacômetro (conta-giros) tal valor também 
deveria ser presumido de acordo com a experiência do instalador.

O kit parcialmente adquirido, fornecido pelas empresas KGM e Netgás, conta com uma válvula gaveta com motor de passo que possibilita ajustes finos na sua abertura (coeficiente de descarga) com o veículo em operação. Seu curso de $8 \mathrm{~mm}$ está dividido em 250 passos. Uma segunda Unidade Eletrônica Central (ECU ou centralina) adquire dados da ECU original, da sonda Lambda e de outros sensores que compõem o sistema de injeção eletrônica do veículo. Tal equipamento confere mais economia e emissão menos nociva de poluentes na atmosfera.

Um joystick para controlar a abertura da válvula gaveta de forma diferente da programada também foi fornecido. Isso permite que se faça ajustes na relação ar-combustível durante o funcionamento do motor ignorando, por exemplo, o sinal da sonda Lambda e de outros sensores que forcem uma condição próxima à estequiométrica à mistura (ajustes on-the-fly). Os ajustes pretendidos são no sentido de aumentar a relação ar-combustível (empobrecer a mistura), buscando melhoras no rendimento termodinâmico e diminuindo o estrangulamento na passagem de ar causada pela borboleta de aceleração. Esse controlador contém dois botões que ordenam à válvula gaveta que essa dê um passo no sentido de restringir ou liberar a passagem de combustível, além de LEDs vermelho e verde que indicam respectivamente o estado de enriquecimento/empobrecimento da mistura.

O kit adquirido conta também com uma chave comutadora entre os sistemas de combustível líquido e gasoso. Nos veículos de passeio adaptados atualmente para o GNV existe a necessidade de dar a partida no motor e funcioná-lo por alguns segundos com combustível líquido antes de passar a usar o combustível gasoso. Apesar da maior facilidade de queimar misturas gasosas, especialmente em baixas temperaturas (partida a frio), motores que não são projetados originalmente para GNV exigem essa condição.

No caso do MAPV há ainda a necessidade de operar o motor com combustível líquido até que a água do sistema de arrefecimento atinja condições de produzir vapor à taxa e pressão necessários. Notou-se que em aproximadamente 10 minutos de funcionamento o sistema já é capaz de fornecer vapor de forma adequada, desde que seja retirada a válvula termostática que permite a circulação de água pelo radiador apenas quando ela atinge determinada temperatura.

\subsubsection{Outros acessórios}

O trocador de calor conta com uma torneira de bóia para controlar a entrada de combustível e mantê-lo num nível adequado para manter os tubos imersos sem transbordar nem permitir que etanol líquido entre no sistema de injeção. Uma bóia de poliamida (nylon), descrita em detalhes no Apêndice D, com 117,3 g de massa e volume útil estimado em 239,3 $\mathrm{cm}^{3}$ fica alojada na câmara auxiliar (tubo de 2") do gerador de vapor, abaixo da tampa por onde entra o com- 
bustível. Com todo o volume útil submerso no etanol, cuja densidade à temperatura de $360 \mathrm{~K}$ $\left(87^{\circ} \mathrm{C}\right.$ ) vale $728,3 \mathrm{~kg} / \mathrm{m}^{3}$ [50], haveria um empuxo líquido (descontado do peso da bóia) de 57,0 gramas-força, mais que suficiente para manter fechada a válvula agulha instalada na tampa de entrada de combustível. Tal válvula tem um orifício de diâmetro de $2,2 \mathrm{~mm}$ na sua entrada de combustível, o que exige uma força de $\left(1,1^{2} \times \pi \times \Delta P\right) \mathrm{mm}^{2}$ para mantê-la fechada, onde $\Delta P$ significa a diferença de pressão. O dosador Racing Parts modelo HPi foi regulado para fornecer à mangueira de alimentação do trocador de calor uma pressão aproximadamente $0,35 \mathrm{kgf} / \mathrm{cm}^{2}$ maior que aquela existente dentro dele. Isso é feito através de uma mangueira ligada na parte inferior do tubo transparente que mostra o nível do combustível dentro do trocador. Ajustando-se o dosador para uma diferença de pressão maior o nível do combustível estabiliza-se mais acima, assim um volume maior de líquido produz um empuxo conseqüentemente maior sobre a bóia que será capaz de fechar a válvula agulha sujeita a maior pressão. Dessa forma pode-se ajustar o nível pretendido dentro do trocador. Observou-se que durante a ebulição do combustível as bolhas levantavam-se até cerca de 30mm acima no nível do líquido, o que levou a um ajuste desse nível entre $30 \mathrm{~mm}$ e $40 \mathrm{~mm}$ abaixo do topo da câmara de evaporação. Neste caso um empuxo líquido de 13,3 gramas-força foi suficiente para fechar a válvula agulha no nível adequado.

Como foi feita uma estimativa conservadora para o cálculo da área de troca térmica e para a diferença de temperatura o trocador foi capaz de fornecer quantidades satisfatórias de vapor em todos os regimes.

Na saída de vapor há uma válvula esfera 3/8" de acionamento manual. Desta forma a mudança da alimentação líquida para a gasosa poderia ser feita de forma gradual ou e uma só vez. A válvula solenóide do kit original não permitia vazões de etanol vaporizado acima de 2,2g/s nas condições dadas. Considerando os dados da tabela 2.4, a pressão de trabalho do evaporador de $0,8 \mathrm{kgf} / \mathrm{cm}^{2}$ acima da pressão barométrica local em torno de $690 \mathrm{mmHg}$; a densidade do vapor de etanol vale aproximadamente $2,80 \mathrm{~kg} / \mathrm{m}^{3}$ (calculada com ajuda do polinômio interpolador do Apêndice B.1), enquanto o metano com peso molecular de $16 \mathrm{~g} / \mathrm{mol}$ e poder calorífico de $56375 \mathrm{~J} / \mathrm{g}$ teria uma relação poder calorífico-volume de

$$
56375 \mathrm{~kJ} / \mathrm{kg} \times 0,714 \mathrm{~kg} / \mathrm{m}^{3}=40251 \mathrm{~kJ} / \mathrm{m}^{3}
$$

Enquanto o vapor de etanol saturado a $172 \mathrm{kPa}$ tem uma quantidade de poder calorífico por volume equivalente a

$$
27710 \mathrm{~kJ} / \mathrm{kg} \times 2,797 \mathrm{~kg} / \mathrm{m}^{3}=77505 \mathrm{~kJ} / \mathrm{m}^{3}
$$

O que indica que a mesma quantidade de volume de etanol gasoso tem uma quantidade consideravelmente maior de energia disponível que o mesmo volume de GNV a temperatura de $0^{\circ} \mathrm{C}$, 
que é a referência para o Normal metro cúbico $\left(\mathrm{Nm}^{3}\right)$. Para uma temperatua de $25^{\circ} \mathrm{C}(297 \mathrm{~K})$ um metro cúbico de GNV à pressão de 1 atmosfera teria:

$$
40251 \frac{273}{297}=36998 \mathrm{~kJ} / \mathrm{m}^{3}
$$

De qualquer forma a quantidade de energia é maior com o mesmo volume de etanol vaporizado. Isso indica que a insuficiência no fornecimento de vapor de etanol deve-se provavelmente à corrosão que esse combustível deve ter causado nos componentes de alumínio. A viscosidade dos gases praticamente não é influenciada pela pressão se essa não estiver próxima de valores críticos [51], e aumenta com a temperatura. Para $100^{\circ} \mathrm{C}$ vale $1,040.10^{-4}$ poise para o vapor de etanol e $1,331.10^{-4}$ para o metano[52].

$\mathrm{Na}$ mudança gradual a válvula esfera era aberta e à medida em que a taxa de produção de vapor aumentava diminuia-se a injeção de combustível líquido através de ajuste no módulo Fueltech (descrito em detalhes adiante). Esse equipamento permite ajustes de mapas de injeção e ignição e também uma modalidade de ajuste rápido onde pode-se aumentar ou diminuir a quantidade de combustível injetado em todo o mapa, bem como adiantar ou atrasar todo o mapa de ignição instantaneamente. Dessa forma os bicos injetores lentamente saíam de cena até que a alimentação estivesse toda por conta do vapor.

Com essa condição alcançada era feita a comutação para gás de forma a permitir o controle da quantidade de vapor admitido por conta do módulo KGM/Netgás. Um simulador de bico, parte integrante do kit GNV, manda sinais para a centralina para que ela continue se comportando como se os bicos injetores estivessem funcionando. Assim, o motor esté pronto para os testes com etanol vaporizado e a centralina Fueltech é usada para controlar o ângulo de ignição e obter medidas mais precisas de MAP.

Foi necessário manter a válvula sonelóide ligada à parte elétrica do sistema, pois a comutação não era realizada se o módulo KGM/Netgás não detectasse sua presença ou outro dispositivo estivesse presente. Válvulas maiores somente podem ser acionadas com uso de relês de estado sólido (que consomem quantidades desprezíveis de corrente elétrica) com a parte equivalente à bobina em paralelo com a válvula original.

Após passar pela válvula esfera e pela válvula gaveta, o vapor de etanol segue por um tubo encamisado (envolvido) por outro pelo qual passa parte da água do sistema de arrefecimento. Dessa forma o combustível é transportado até o bocal de admissão sem o risco de condensação. O bocal, confeccionado em latão, também tem furos por onde passa água quente para a mesma finalidade. Entre o tubo e a entrada de combustível no bocal há aprozimadamente $20 \mathrm{~mm}$ de mangueira transparente para garantir que não há escoamento de líquido através do sistema. A parte não transparente foi isolada com espuma expansível de poliuretano, enquanto as válvulas que precisaram de muitas desmontagens foram isoladas termicamente com lã de vidro. As 
mangueiras que levam água saída do bloco do motor em direção ao evaporador também foram isoladas.

O mesmo sinal de 12 Volts é bifurcado entre o solenóide e o simulador de bico. Portanto podese presumir que esse último é ligado apenas quando o motor passa a operar com combustível gasoso. Devido à distância existente entre geração e admissão de vapor (aproximadamente $700 \mathrm{~mm}$ ) foi instalado um retardador de sinal (figura 3.3.1) para que houvesse um intervalo entre o início do funcionamento do sistema de alimentação gasosa e o corte na injeção de combustível líquido. O retardador é regulável para aguardar entre $0,5 \mathrm{~s}$ e $5,5 \mathrm{~s}$, mantendo a tensão de $12 \mathrm{~V}$ na alimentação do simulador de bico.

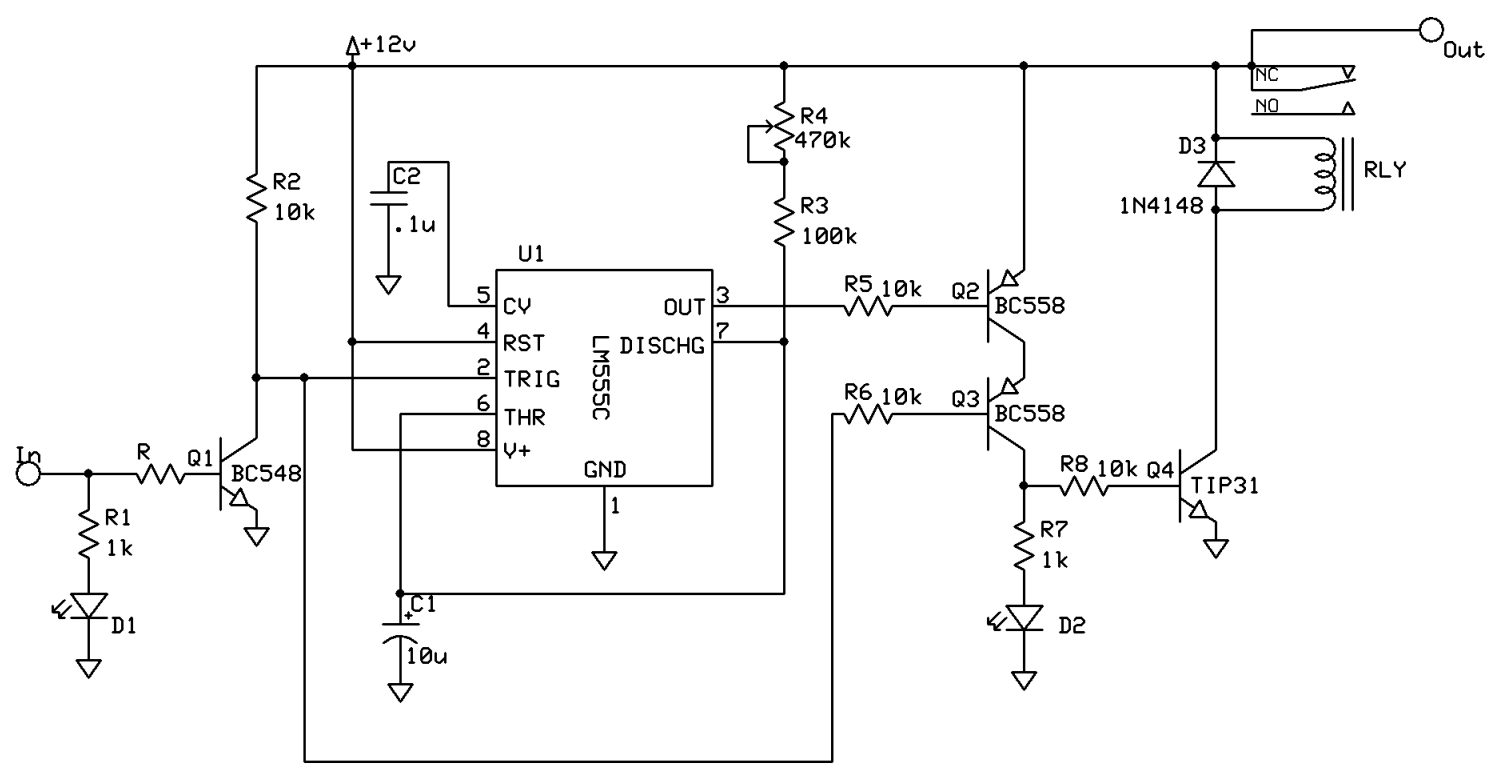

Figura 3.1: Diagrama elétrico do retardador de sinal utilizado.

\subsubsection{Adaptações na válvula gaveta}

Inicialmente tentou-se operar o MAPV com a válvula gaveta original, que foi danificada pelo combustível a alta temperatura e pelos golpes de ariete causados por condensações e imperfeições no funcionamento do gerador de vapor. Suas bobinas tiveram o verniz removido e entraram em curto-circuito. Foi confeccionada uma adaptação para a nova válvula, do mesmo modelo, de forma a protegê-la do calor excessivo e do combustível. A ponta esférica da válvula original foi substituída por um pino que desloca-se dentro de uma bucha com furo calibrado, de forma a controlar uma janela com área menor que a original. Isso foi necessário pelo fato de não se usar redutor de pressão, que exigiria uma válvula gaveta com baixo coeficiente de descarga e que permitisse passagem de gás de acordo comuma relação quase linear com a área da janela. $\mathrm{O}$ 
método usado foi o de reduzir-se a pressão do trocador de calor para um valor próximo daquele existente na admissão através de uma passagem mais restritiva. Tais adaptações estão descritas no Apêndice D.

\subsubsection{Dispositivo de sucção ou Venturi}

O Venturi fornecido também não mostrou-se adequado para o uso no MAPV, exigindo o projeto de um novo. Os principais motivos foram:

- Distribuição não uniforme de combustível devido à entrada do mesmo acontecer de forma perpendicular à passagem de ar. Como o eixo da borboleta não é paralelo ao da árvore de manivelas uma concentração desigual de combustível em determinado local é indesejável, pois pode levar a alguns cilindros mistura mais rica do que em outros. O novo Venturi admite o vapor de etanol de forma tangencial, em uma câmara toroidal (formato semelhante ao de um biscoito de polvilho), para daí ser sugado pelo ar.

- Necessidade de manter o dispositivo aquecido para evitar condensação de vapor em seu interior, purgas periódicas e golpes de ariete. Para isso o Venturi foi construído em latão, bom condutor de calor, e dotado de canais pelos quais passam água do sistema de arrefecimento que mantém a peça aquecida a temperatura maior que a de condensação do etanol.

- Fixação adequada ao corpo de borboleta. O Venturi original foi concebido para ficar preso ao corpo de borboleta com ajuda da fixação desse ao filtro de ar.

- Vedação. Pelo mesmo motivo do item anteiror há O'rings ou outros dispositivos para evitar o vazamento de combustível na maneira em que ele foi fixado.

- Minimizar as perdas de carga, produzindo uma peça com melhor acabamento superficial, aumentando o diâmetro mínimo de passagem de ar, eliminando ângulos e arestas indesejáveis.

O lado interno do Venturi foi isolado com borracha de silicone não-acético, havendo canais previstos para alojá-la. Isso é necessário para evitar transmissão de calor ao ar admitido, que pode diminuir sua densidade causando prejuízos ao rendimento volumétrico. O que já é um problema com injeção indireta de combustiel gasoso.

A pressão em diferentes seções do Venturi foi calculada no regime de máxima potência (máxima vazão de ar) com base nas equações que definem o estado do ar em um escoamento compressível 
através de bocal convergente-divergente [53]. Houve a preocupação de determinar-se a pressão absoluta na menor seção do Venturi, onde acontece a sucção de combustível.

O consumo de ar com o mesmo motor foi medido anteriormente por D'Ávila [23]. A plena carga, a 5000rpm, o motor usado consome $29,56 \mathrm{~g} / \mathrm{s}$ com etanol vaporizado a temperatua ambiente de $32,5^{\circ} \mathrm{C}$ e pressão de $696 \mathrm{mmHg}$ (92793Pa). Pressão e velocidade do ar foram calculados na mangueira de 2" que liga o plenum ao corpo de borboleta e na menor seção do Venturi, com diâmetro de $35 \mathrm{~mm}$.

$$
\begin{gathered}
\rho_{0}=\frac{p}{R T}=1,092 \mathrm{Kg} / \mathrm{m}^{3} \\
\frac{Q}{A}=p_{0} \sqrt{\frac{\gamma}{R T_{0}}} M\left[1+0,5(\gamma-1) M^{2}\right]^{0,5-\frac{\gamma}{\gamma-1}} \\
\frac{Q}{A}=14,585 \mathrm{~kg} / \mathrm{m}^{2} \mathrm{~s} \longrightarrow M_{1}=0,03869(13,2 \mathrm{~m} / \mathrm{s}) \\
\frac{A_{1}}{A_{2}}=\frac{M_{2}}{M_{1}}\left[\frac{1+0,5(\gamma-1) M_{2}^{2}}{1+0,5(\gamma-1) M_{1}^{2}}\right]^{0,5-\frac{\gamma}{\gamma-1}} \\
\frac{p_{1}}{p_{2}}=\left[\frac{1+0,5(\gamma-1) M_{2}^{2}}{1+0,5(\gamma-1) M_{1}^{2}}\right]^{0,5-\frac{1}{\gamma-1}} \\
M_{2}=0,1463(49,81 \mathrm{~m} / \mathrm{s}) \quad M_{3}=0,0818(27,85 \mathrm{~m} / \mathrm{s}) \\
\frac{p_{1}}{p_{0}}=0,9989 \quad \frac{p_{2}}{p_{0}}=0,9852 \quad \frac{p_{3}}{p_{0}}=0,9953
\end{gathered}
$$

As seções 0, 1, 2 e 3 referem-se, respectivamente, ao plenum onde o ar encontra-se nas propriedades de estagnação; a mangueira de 2" já descrita; à seção de $29 \mathrm{~mm}$ de diâmetro do Venturi adquirido no kit de conversão para GNV e; à seção de 35mm de diâmetro do Venturi construído separadamente. $\mathrm{M}$ representa o número de Mach, $\mathrm{T}$ a temperatura, $\mathrm{R}$ a constante universal dos gases e $p$ a pressão absoluta.

Os valores calculados para velocidade do ar são muito pequenos em relação à velocidade do som para as condições dadas, o que torna o escoamento praticamente imcompressível. Os valores de queda de pressão também são baixos em relação à pressão atmosférica, levando a menores variações na diferença de pressão em relação à pressão de vapor produzido, facilitando o controle da vazão de combustível através da válvula de passo. O diâmetro de $35 \mathrm{~mm}$ para a sucção só foi necessário para comportar a câmara toroidal onde o vapor circula antes de ser admitido e para forçar um aumento na velocidade do ar visando ajudar na homogenização da mistura inflamável. 


\subsubsection{Resposta do sistema a variações na demanda de combustível}

Um preocupação importante no projeto do sistema de alimentação para um MAPV é com o fornecimento de vapor ao motor de acordo com sua necessidade instantânea (fornecimento on demand). Também é necessário atender prontamente a alternações no consumo de combustível, fornecendo a quantidade correspondente ao regime de operação pretendido pelo condutor. Como o combustível não é transportado já na forma gasosa, caso do GNV, do GLP e de alguns MCI's movidos a hidrogênio; é importante produzir vapor a uma taxa o mais próximo possível da necessária. Aproximando-se produção e consumo de vapor evita-se grandes acúmulos ou diminuições da quantidade de vapor no sistema. A quantidade ideal de combustível armazenado é um compromisso entre a segurança (menor quantidade de combustível saturado) e a capacidade de atender a variações na demanda.

A entrada de combustível líquido é controlada por uma bóia, por um princípio semelhante ao das bóias usadas em cubas de carburadores. À medida em que o combustível entra no trocador, seu nível aumenta o empuxo da bóia, até atingir valor suficiente para tapar o furo de $2 \mathrm{~mm}$ de diâmetro porporcionando força para resistir à pressão do sistema de alimentação. Com a saída de combustível do equipamento, na forma gasosa, o nível do combustível abaixa novamente, permitindo sua entrada para reposição.

Na superfície de troca de calor a taxa de ebulição não é exatamente proporcional à diferença de temperatura entre fluido e parede. Há ainda uma temperatura mínima para iniciar a ebulição. De qualquer forma, à medida que a temperatura do fluido sob ebulição aproxima-se da temperatura do fluido que fornece calor (no caso a água do sistema de arrefecimento) há uma diminuição da produção de vapor, até chegar a zero quando a diferença de temperatura cai abaixo de determinado valor. Dessa forma, quando a demanda por combustível for menor, o vapor produzido fica acumulado no trocador, aumentando sua pressão. À medida que a pressão aumenta, aumenta também a temperatura de saturação para o etanol, o que permite que o combustível atinja temperaturas maiores antes de começar a evaporar-se. A aproximação com a temperatura da água diminui a taxa de evaporação, adequando-a à demanda.

No caso contrário, quando a demanda por combustível aumenta repentinamente, por exemplo quando o morotista exige mais potência para uma ultrapassagem, a saída de gás do trocador faz a pressão cair, com imediato decréscimo da temperatura, semelhante à queda de temperatura observada em sistemas frigoríficos quando o fluido refrigerante sofre queda brusca de pressão. Nesse caso a diferença de temperatura entre os fluidos aumenta. Enquanto a produção de vapor não atinge a taxa desejada, parte do combustível líquido saturado evapora-se sem receber necessariamente mais calor da superfície de troca térmica. Isso acontece simplesmente pelo fato de o título aumentar com a expansão não resistida do fluido. É a geração de vapor flash, comum 
em sistemas frigoríficos e instalações de vapor d'água. Enquanto a produção de vapor não se adequa, o vapor flash atende a exigência do motor.

Dessa forma o sistema ajusta-se automaticamente às variações no consumo de combustível, comuns aos MCIs não-estacionários. 


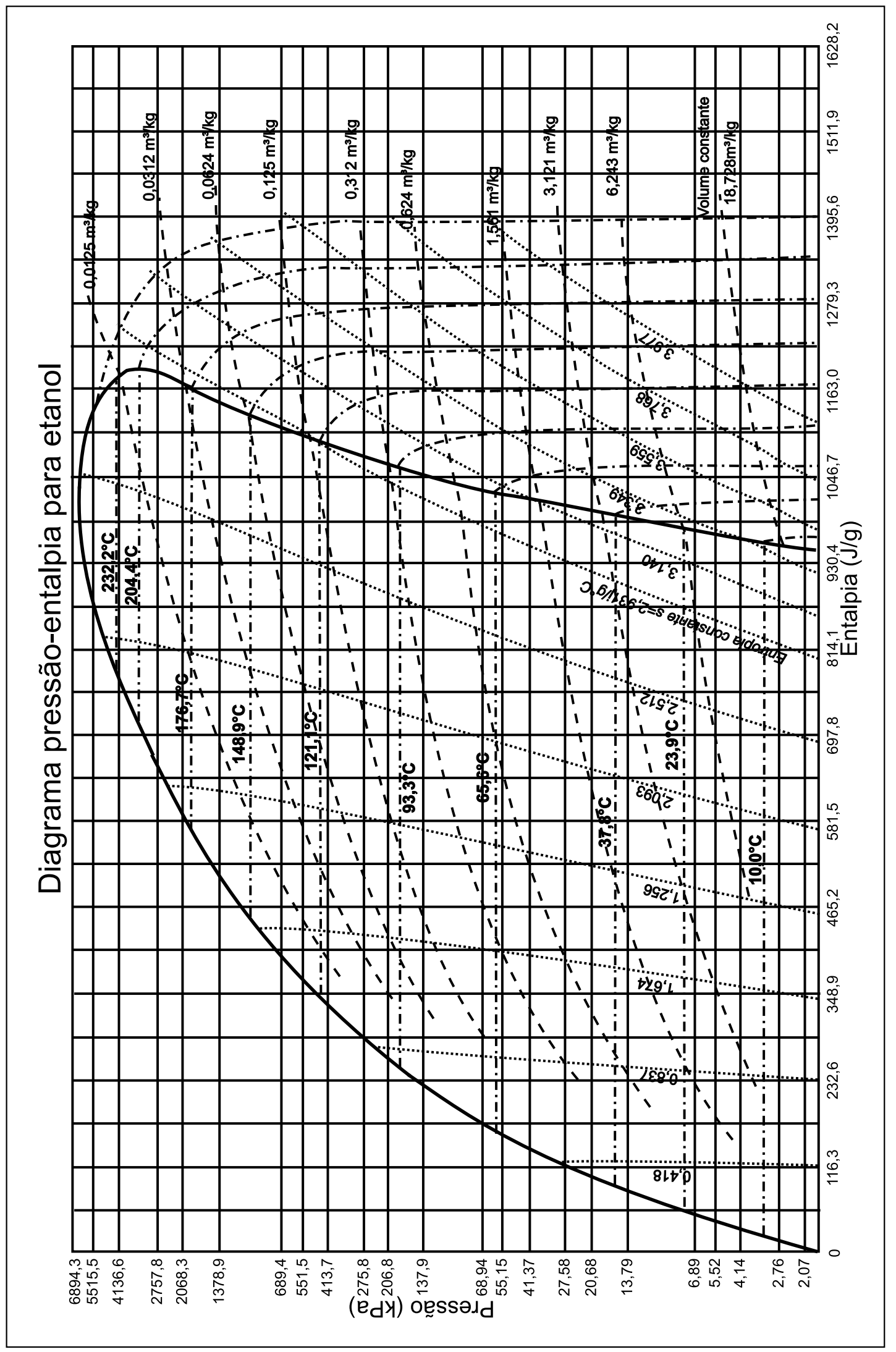

Figura 3.2: Relação entre pressão, entalpia, entropia, volume específico e temperatura de saturação para etanol.

Adaptado e convertido para unidades SI a partir de [54]. 
A figura 3.2 mostra um diagrama pressão-entalpia para etanol. Nele estão relações entre propriedades físicas e termodinâmicas para essa substância.

\subsubsection{Controle da pressão de vapor}

Como a temperatura da água de arrefecimento não é constante durante a operação de um MCI não estacionário, a diferença entre ela e a do etanol em satuação pode variar também. Conforme descrito anteiriormente variações no consumo também alteram a pressão no gerador de vapor. Numa primeira tentativa foi instalada uma válvula reguladora de pressão usada para controlar a vazão de GLP em fogões domésticos, com vazão nominal de $1 \mathrm{~kg} / \mathrm{h}$. Dessa forma a pressão no trocador poderia variar mas na saída dessa válvula a pressão seria sempre de alguns kPa acima da pressão atmosférica, de forma que uma válvula gaveta semelhante à original pudesse ser usada. Nessa etapa o motor de passo já estava protegido de altas temperaturas e da contaminação por etanol. A outra diferença em relação à válvula original foi a substituição da ponta esférica de alumínio por outra cônica, de PTFE (Politetrafluoretileno) acompanhada de um furo cônico com dimensões compatíveis na caracaça da válvula gaveta. A válvula reguladora de pressão também contava com um encamisamento com água do arrefecimento para evitar condensação. Essa solução não se mostrou adequada porque essa válvula não é capaz de fornecer gás na vazão necessária. Válvulas com maior vazão nominal, porém, podem ser usadas seguindo o mesmo princípio. A experiência mostrou que a vazão nominal de vapor de etanol é de aproximadamente metade daquela indicada para gases como GLP ou gás natural. A maior viscosidade do vapor de etanol provavelmente é a principal responsável por essa diferença.

Com a vávlula gaveta usando a bucha de latão, furo e pino calibrados, descartou-se o regulador de pressão e passou a admitir-se diretamente a pressão do trocador nessa válvula, de modo que a menor área de passagem de gás causasse a perda de pressão necessária, conforme explicado anteriormente. O inconveniente que surgiu foi a variação da temperatura da água do arrefecimento de acordo com os ciclos de operação da ventoinha do radiador. A válvula termostática ("cebolão") original fecha o contato permitindo a passagem de corrente elétrica quando a água atinge $95^{\circ} \mathrm{C}$ e abre seu contato elétrico quando a água atinge $87^{\circ} \mathrm{C}$. Esse "cebolão" foi trocado por outro que fecha contato a $100^{\circ} \mathrm{C}$ e abre a $95^{\circ} \mathrm{C}$. Notou-se uma variação na pressão do trocador entre $1,0 \mathrm{kgf} / \mathrm{cm}^{2}$ e $0,7 \mathrm{kgf} / \mathrm{cm}^{2}$ nesse caso. Tal variação de pressão é prejudicial ao funcionamento estável do motor. Em regime constante de rotação e TPS a mistura passava de rica ou estequiométrica para pobre, impedindo que medidas adequadas fossem feitas.

Ao ligar-se a ventoinha durante todo o tempo a temperatura da água de arrefecimento caiu para abaixo de $80^{\circ} \mathrm{C}$, e quando a diferença entre essa e o álcool em saturação caiu para abaixo de $6^{\circ} \mathrm{C}$ a produção de vapor cessou imediatamente e o motor ficou sem fornecimento de combustível 
gasoso, confirmando a teoria apresentada por Thome [44].

Uma solução que se mostrou adequada foi instalar um dispositivo que controlasse a velocidade da ventoinha, de forma que ficasse em um valor que resultasse em uma temperatura constante da água.

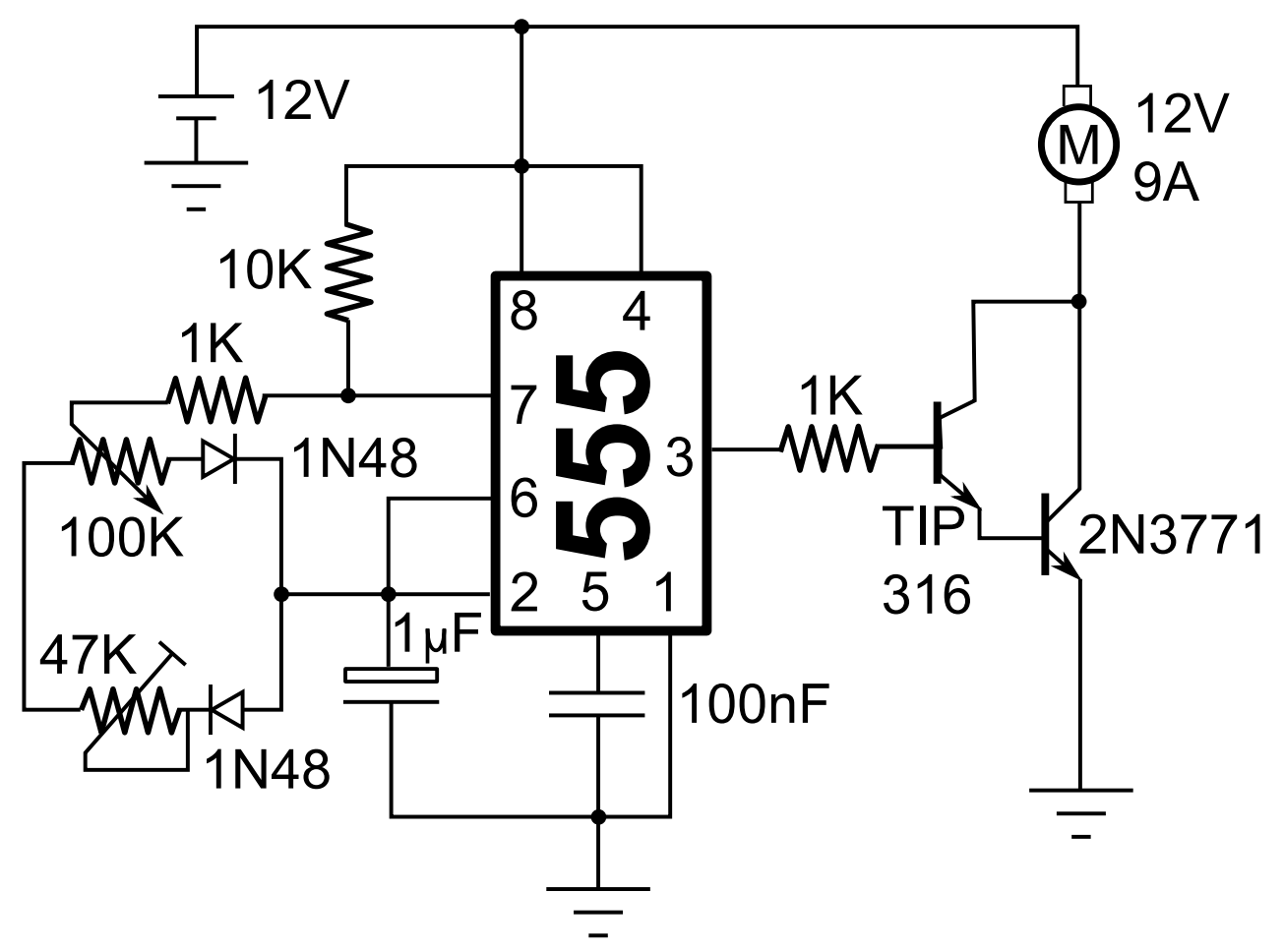

Figura 3.3: Diagrama elétrico do regulador de velocidade da ventoinha.

\subsection{Outros aparatos experimentais}

Dinamômetro de corrente de Foucault marca Schenck, modelo W70.

Célula de carga Alfa Instrumentos modelo IC331/0

Scanner de injeção eletrônica Tecnomotor Rasther TM 131.

Sistema de aquisição de temperatura Strawberry Tree ACPC analógico com 8 canais e termopares cromel-alumel. As temperaturas medidas foram: Bocal de admissão, coletor de admissão, coletor de escape, vapor de etanolna saída do trocador, óleo lubrificante, água do arrefecimento na entrada e na saída do gerador de vapor.

Radiador marca Bongotti, modelo desconhecido, sabe-se que equipa o motor do Ford Corcel 2. Balança Hobart Dayton modelo CB15 com capacidade para $15 \mathrm{~kg}$ e resolução de $10 \mathrm{~g}$, cronômetro Alfa Instrumentos TCC11 e sensores ópticos para medições de consumo de combustível. 
Medidor de vazão de ar Bosch modelo 0280218053.

Manômetro Classe B ABNT de 0 a $3 \mathrm{kgf} / \mathrm{cm}^{2}$ para monitorar o gerador de vapor. Manômetro marca Emfase de $600 \mathrm{mmHg}$ (vácuo) até $0,5 \mathrm{kgf} / \mathrm{cm}^{2}$ para medidas de MAP. Analisador de gases Tecnomotor TM131.

\subsection{Configuração da bancada}

Os equipamentos comunicam-se e estão dispostos de acordo com a figura 3.5. Os dispositivos eletrônicos construídos estão detalhadamente apresentados nas figuras anteriores. A balança conta com sensores ópticos ligados a um cronômetro (38) para determinar o tempo que o motor demora para consumir determinada quantidade de combustível, enquanto a abertura da válvula 21 reabastece o tanque secundário (18) apoiado sobre a balança (16) para uma nova medida de consumo. O ignorador de sinal (37) envia o sinal da primeira passagem do ponteiro da balança pelo sensor óptico ao cronômetro, ignora o sinal da segunda interrupção durante seu retorno, transmite o terceiro sinal ao cronômetro para que encerre a contagem e na quarta passagem (segundo retorno) zera o cronômetro para iniciar uma nova medida. Após a primeira passagem do ponteiro um peso de $100 \mathrm{~g}$ era adicionado ao prato da balança, de formaque na terceira passagem a balança suportava exatamene o mesmo peso, tendo os $100 \mathrm{~g}$ de etanol substituídos por 100 gramas do peso externo. Dessa forma era medido o tempo necessário para que o motor consumisse 100 gramas de combustível, tanto na operação com combustível líquido quanto com combustível vaporizado. Para cada modo há um retorno de combustível distinto, sendo que o retorno do circuito de vaporização estava ligado ao tanque através do retorno do dosador. Em qualquer caso, a quantidade medida era a diferença entre o que foi sugado pela bomba de combustível e o que foi devolvido via retorno.

A ECU secundária adquirida do kit GNV corta o fornceimento de combustível líquido quando solicitado o uso de combustível gasoso, interrompendo o sinal dos bicos injetores, porém mantendo a bomba de combustível em funcionamento e a pressão na flauta. Em compensação a válvula (25) é aberta permitindo a passagem de combustível gasoso. O manômetro (29) indica se há condições para isso, presões próximas a $0,7 \mathrm{kgf} / \mathrm{cm}^{2}$ indicam que já se pode começar a operar o motor com combustível vaporizado. A comutação líquido-gás é feita manualmente no kit GNV e com a abetura da válvula esfera (31). O manômetro (30) informa a pressão com a qual o trocador de calor é alimentado, sendo que dentro dele há uma bóia ligada a uma válvula agulha usada em crburadores. O dosador HP adquirido da empresa Racing Parts (20) permite determinar a diferença de pressão entre a alimentação e a pressão no trocador de calor, que é informada a esse dispositivo através da mangueira (28). Foi ajustada uma diferença de pressão 


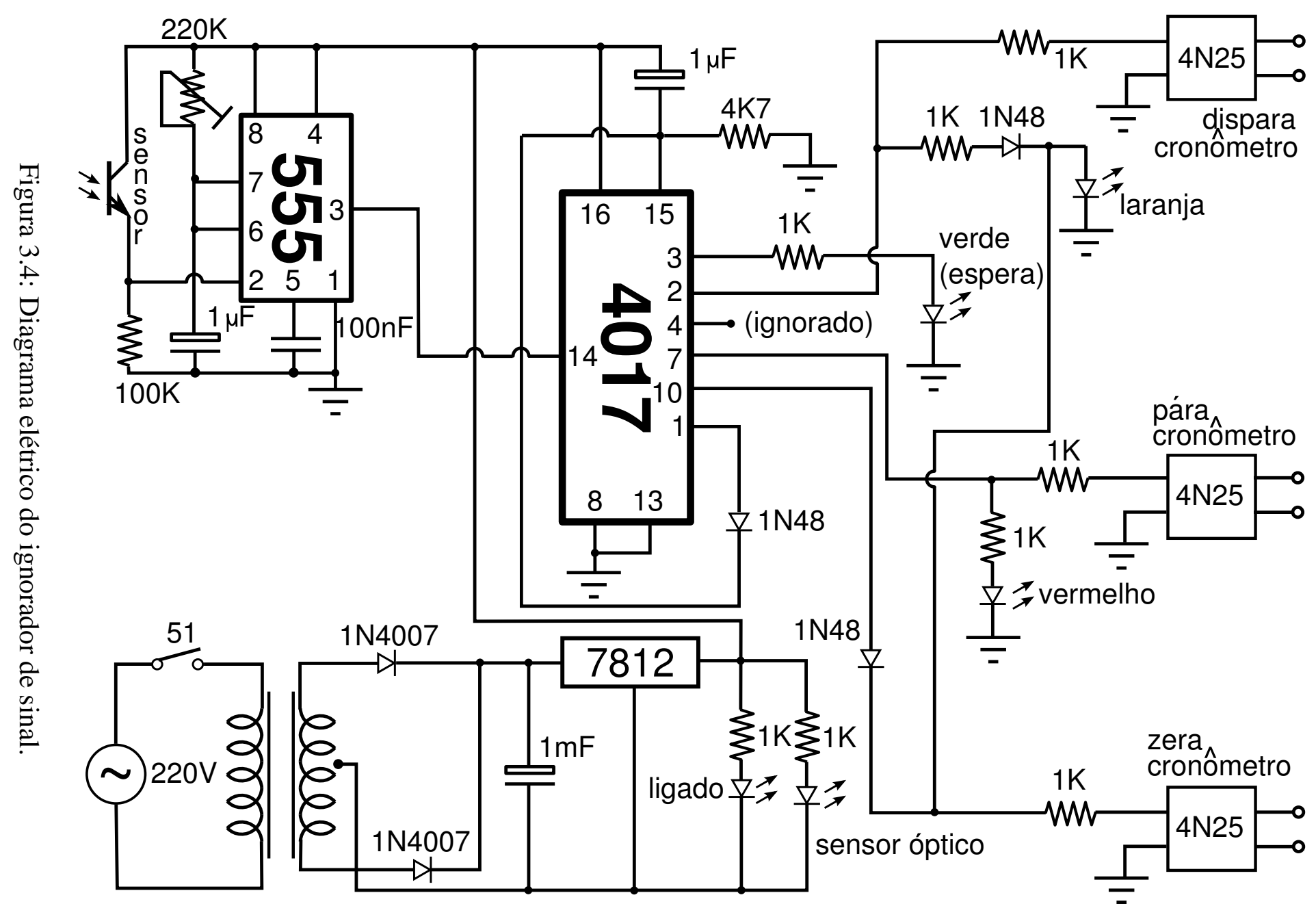


de $0,22 \mathrm{kgf} / \mathrm{cm}^{2}$ para que o nível do combustível ficasse adequado dentro do gerador. O abastecimento do gerador é feito aproveitando-se o funcionamento da bomba de combustível original, com o regulador de pressão original fechado, já que trabalha-se numa pressão menor que a que provocaria sua abertura.

Os gases de escape passam por resfriamento antes de seguir para o analisador a fim de retirar vapor d'água que pode danificar tal equipamento. A água do arrefecimento passa pelo gerador de vapor (22) antes de seguir para o radiador (23), tendo parte desviada pela linha (27) para manter aquecidos o Venturi e o tubo encamisado (26), evitando condensação de vapor desde seu local de produção até o coletor de admissão.

Descrição: 1-Tomada de ar com medidor de vazão; 2-Plenum; 3-Mangueira; 4-Venturi oco; 5-Corpo de borboleta; 6-Coletor de admissão; 7-Flauta; 8-Motor; 9-Coletor de escape; 10 Condensador; 11-Analisador de gases; 12-Volante e eixo cardan; 13-Dinamômetro de célula de carga; 14-Acelerador; 15-Leitura do dinamômetro; 16-Balança; 17-Tanque de combustível; 18-Tanque auxiliar; 19-Bomba de combustível; 20-Dosador; 21-Válvula do tanque auxiliar; 22-Gerador de vapor; 23-Radiador; 24-Válvula co motor de passo (controle fino da vazão de vapor); 25-Válvula solenóide do sitema de vapor; 26-Tubo encamisado; 27-linha de água aquecedora do Venturi e do tubo encamisado; 28-Infomração de pressão para o dosador; 29-Pressão no gerador de vapor; 30-Pressão de alimentação do gerador; 31-Válvula esfera (alimentação); 32-Manômetro MAP; 33-ECU Netgás com simulador de bico; 33-ECU Fueltech; 35-Joystick Netgás; 36-Distribuidor e velas; 37-Ignorador de sinal; 38-Cronômetro; 39-Retardador de sinal; 40-Controlador de velocidade da ventoinha; 41-redutor de pressão do sistema de injeção original. 


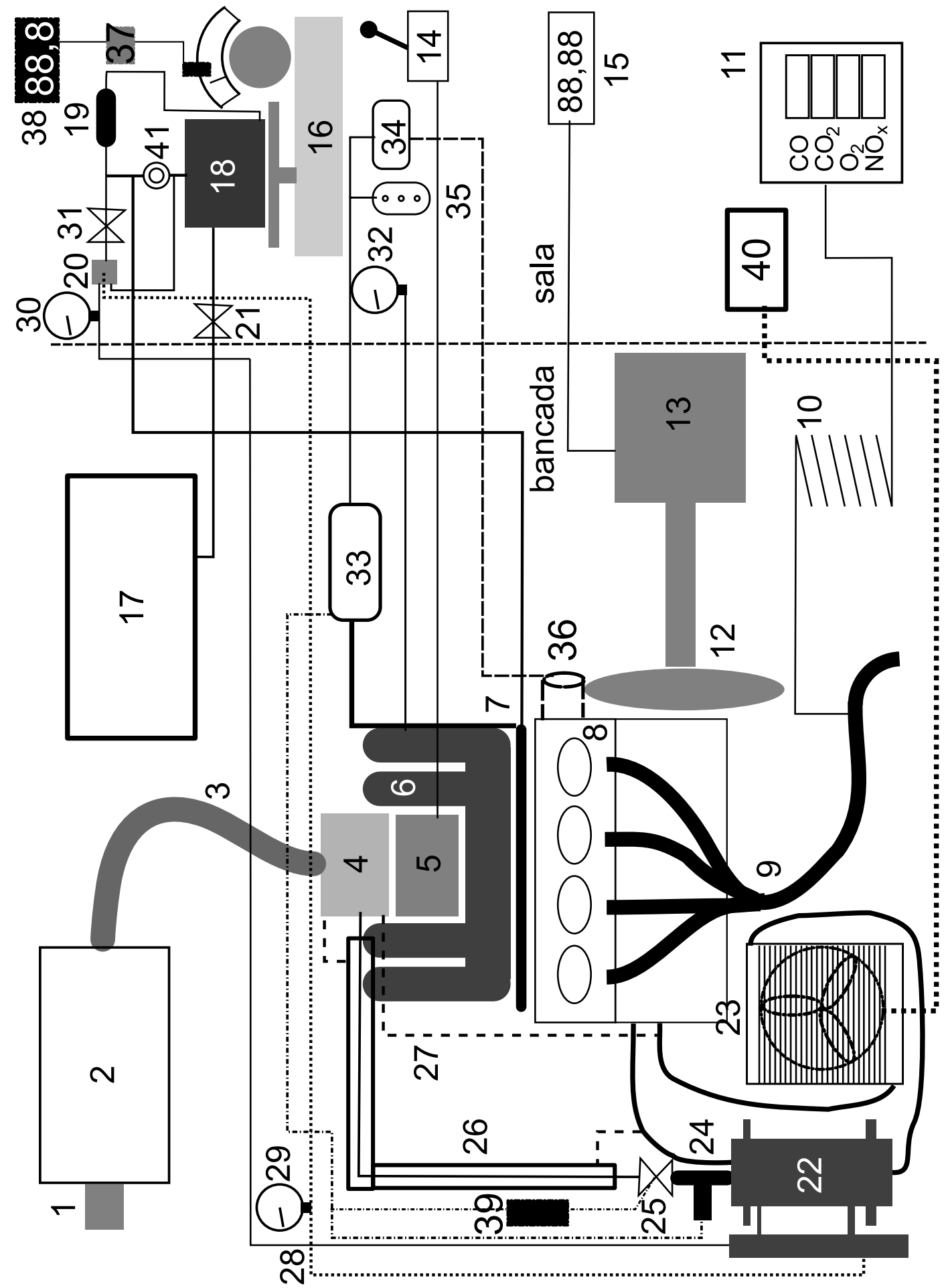

Figura 3.5: Disposição dos equipamentos. 


\section{Capítulo 4}

\section{Resultados experimentais}

\subsection{Sistema original de injeção}

Para efeito de comparação de resultados o motor foi ensaiado com seu sistema original de injeção eletrônica antes de se utilizar o álcool vaporizado. As tabelas 4.1, 4.2 e 4.3 a seguir fornecem os resultados sobre o funcionamento do motor nessa condição. A intenção é comparar consumo e emissões específicas para a mesma combinação torque-rotação. Dez regimes foram estudados, sendo nove formados pela combinação de três aberturas da válvula borobleta (25\%, $50 \%$ e 100\%)com três regimes de rotação (2000, 3000 e 4000 rpm); além da marcha-lenta.

Notou-se que com o acelerador totalmente aliviado o scanner Tecnomotor acusava abertura da borboleta de aceleração em $4^{\circ}$, enquanto a ECU Fueltech foi devidamente calibrada para marcar $0,00 \%$ nessa condição. Da mesma forma a abertura máxima era percebida como $82^{\circ} \mathrm{e} 100,00 \%$ pelos mesmos aparelhos, respectivamente. Para trabalhar com todas as medidas em porcentual da abertura máxima, as medidas realizadas em graus com a ECU original foram convertidas pela expressão

$$
\left(\frac{g-4}{78}\right) \times 100=\text { porcentual }
$$

Onde $g$ é a medida da abertura da borboleta de aceleração em graus.

Todas as tabelas foram elaboradas com base nos dados colhidos para o motor (Apêndice C) e calculadas em uma planilha eletrônica ODF (Open Document Format) pelo software Open Office versão 2.0.4. As fórmulas utilizadas estão descritas na seção B.2.

\section{2 Álcool vaporizado}

Para cada regime estudado, partiu-se na alimentação com etanol vaporizado de condição semelhante àquela determinada no sistema original de alimentação. O primeiro regime ensaiado em cada caso foi aquele com mesma abertura de borboleta de aceleração e mistura estequiométrica, 
Tabela 4.1: Produtos de combustão em base seca, com sistema de injeção original.

\begin{tabular}{|c|c|c|c|c|c|c|c|}
\hline $\begin{array}{c}\omega \\
(\mathrm{rpm})\end{array}$ & $\begin{array}{c}\text { Vazão total } \\
\text { PCBS (mol/h) }\end{array}$ & $\begin{array}{l}\mathrm{CO} \\
(\mathrm{g} / \mathrm{h})\end{array}$ & $\begin{array}{l}\text { THC } \\
(\mathrm{g} / \mathrm{h})\end{array}$ & $\begin{array}{l}\mathrm{NO}_{x} \\
(\mathrm{~g} / \mathrm{h})\end{array}$ & $\begin{array}{l}\mathrm{CO}_{2} \\
(\mathrm{~g} / \mathrm{h})\end{array}$ & $\begin{array}{c}\mathrm{O}_{2} \\
(\mathrm{~g} / \mathrm{h})\end{array}$ & $\begin{array}{l}\mathrm{N}_{2} \\
(\mathrm{~g} / \mathrm{h})\end{array}$ \\
\hline \multicolumn{8}{|c|}{ Marcha lenta } \\
\hline 8480 & 254 & 30 & 2 & 0 & 1589 & 76 & 6351 \\
\hline \multicolumn{8}{|c|}{ Borboleta a $25 \%$ (23 graus) } \\
\hline 2000 & $\overline{579}$ & 52 & 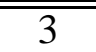 & 34 & 6467 & 128 & 25154 \\
\hline 3000 & 1156 & 110 & 13 & 67 & 7378 & 255 & 29158 \\
\hline 4000 & 1195 & 151 & 25 & 43 & 7469 & 310 & 29821 \\
\hline \multicolumn{8}{|c|}{ Borboleta a 50\% (45 graus) } \\
\hline$\overline{2000}$ & 1458 & $\overline{c 102}$ & 55 & 85 & 9107 & 387 & 36116 \\
\hline 3000 & 2315 & 194 & 43 & 136 & 14566 & 570 & 57598 \\
\hline 4000 & 3183 & 339 & 130 & 187 & 19745 & 866 & 78942 \\
\hline \multicolumn{8}{|c|}{ Abertura total da borboleta ( 82 graus) } \\
\hline$\overline{2000}$ & 1460 & 1275 & 51 & 44 & 8287 & 149 & 37248 \\
\hline 3000 & 2353 & 2214 & 64 & 54 & 13252 & 196 & 60069 \\
\hline 4000 & 3381 & 2329 & 60 & 128 & 19784 & 335 & 85624 \\
\hline
\end{tabular}

Tabela 4.2: Produção específica de alguns gases e consumo específico de combustível, com alimentação original de combustível.

\begin{tabular}{|c|c|c|c|c|c|c|}
\hline$\omega$ & \multicolumn{5}{|c|}{ Produção específica (g/kWh) } & \multirow{2}{*}{$\begin{array}{c}\text { Cons. específico } \\
\text { Etanol }\end{array}$} \\
\hline$(\mathrm{rpm})$ & $\mathrm{CO}$ & THC & $\mathrm{NO}_{x}$ & $\mathrm{CO}_{2}$ & $\mathrm{O}_{2}$ & \\
\hline \multicolumn{7}{|c|}{ Borboleta a 25\% (23 graus) } \\
\hline 2000 & 6,6 & 0,38 & $4 \overline{4,25}$ & 820 & 16,2 & 515,5 \\
\hline 3000 & 14,3 & 1,68 & 8,73 & 956 & 33,1 & 585,0 \\
\hline 4000 & 33,4 & 5,49 & 9,57 & 1657 & 68,7 & 1004,9 \\
\hline \multicolumn{7}{|c|}{ Borboleta a $50 \%$ (45 graus) } \\
\hline 2000 & 8,5 & 4,58 & 7,09 & 758 & 32,2 & 450,5 \\
\hline 3000 & 10,2 & 2,25 & 7,11 & 763 & 29,9 & 455,9 \\
\hline 4000 & 13,8 & 5,30 & 7,64 & 806 & 35,3 & 486,1 \\
\hline \multicolumn{7}{|c|}{ Abertura total da borboleta (82 graus) } \\
\hline 2000 & 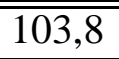 & $4,4,13$ & $3,3,56$ & 675 & 12,2 & 518,6 \\
\hline 3000 & 109,4 & 3,17 & 2,65 & 655 & 9,7 & 511,4 \\
\hline 4000 & 82,7 & 2,13 & 4,54 & 702 & 11,9 & 509,9 \\
\hline
\end{tabular}


Tabela 4.3: Demais parâmetros calculados, referentes ao funcionamento do motor com ECU original.

\begin{tabular}{|c|c|c|c|c|c|c|c|}
\hline $\begin{array}{c}\omega \\
(\mathrm{rpm})\end{array}$ & $\begin{array}{c}\text { Torque } \\
(\mathrm{Nm})\end{array}$ & $\begin{array}{c}\text { Potência } \\
\text { observada }(\mathrm{kW})\end{array}$ & $\begin{array}{c}\eta \\
(\%) \\
\end{array}$ & $\begin{array}{l}\text { Consumo } \\
\text { etanol }(\mathrm{g} / \mathrm{s})\end{array}$ & $\Lambda$ & $\bar{\lambda}$ & $\begin{array}{c}\text { MAP } \\
(\mathrm{mmHg})\end{array}$ \\
\hline \multicolumn{8}{|c|}{ Marcha lenta } \\
\hline 840 & - & - & - & 0,26 & 8,70 & 1,04 & 306,0 \\
\hline \multicolumn{8}{|c|}{ Borboleta a 25\% (23 graus) } \\
\hline 2000 & 37,7 & 7,89 & 28,0 & 1,13 & 8,07 & 0,97 & 513,5 \\
\hline 3000 & 24,6 & 7,72 & 24,7 & 1,25 & 8,42 & 1,01 & 383,5 \\
\hline 4000 & 10,8 & 4,51 & $\overline{14,4}$ & 12,6 & 8,58 & 1,03 & 253,5 \\
\hline \multicolumn{8}{|c|}{ Borboleta a 50\% (45 graus) } \\
\hline 2000 & 57,4 & 12,02 & 32,1 & 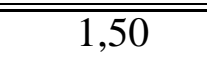 & 8,70 & 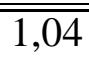 & 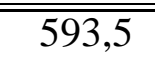 \\
\hline 3000 & 60,8 & 19,10 & 31,7 & 2,42 & 8,62 & 1,04 & 573,5 \\
\hline 4000 & 58,5 & 24,49 & 29,7 & 3,31 & 8,65 & 1,04 & 643,5 \\
\hline \multicolumn{8}{|c|}{ A Abertura total da borboleta (82 graus) } \\
\hline 2000 & 58,6 & 12,28 & 27,9 & 1,77 & 7,62 & 0,92 & 686,0 \\
\hline 3000 & 64,4 & 20,23 & 28,2 & 2,87 & 7,57 & 0,91 & 678,0 \\
\hline 4000 & 67,3 & 28,17 & 28,3 & 3,99 & 7,77 & 0,93 & 676,0 \\
\hline
\end{tabular}

com a preocupação de encontrar um ângulo de ignição que proporcionasse máximo torque. Em alguns casos excepcionais pôde-se influir nas emissões com mudanças nesse parâmetro. Nas tabelas C.4 e C.5 cada regime é caracterizado pelos parâmetros: rotação, abertura porcentual da borboleta de aceleração, razão normalizada ar-combustível calculada pelo analisador de gases e ângulo de ignição medido pela pistola estroboscópica.

Várias aberturas foram testadas, de forma a permitir uma maior taxa de admissão de ar, com o objetivo de operar o motor de forma mais eficiente e controlar determinadas emissões.

Não foi usual alterar a abertura da válvula gaveta (que dosa o combustível gasoso). Em alguns poucos casos foi necessário alterar a sua abertura entre regimes que seriam comparados com o mesmo regime de injeção original.

Foi observado que para a mesma abertura de válvula gaveta, regimes com maiores taxas de consumo de ar também levavam a maiores consumos de vapor de etanol, o que é condizente com a característica do Venturi de causar uma sucção maior do combustível com maior vazão de ar. Entretanto, a mistura ar-combustível ficou mais pobre à medida em que mais ar era admitido, conforme esperado. $\mathrm{O}$ aumento no consumo de combustível foi relativamente baixo. 
Tabela 4.4: Grandezas mecânicas e hidráulicas para os regimes operados com sistema de injeção de vapor de etanol.

\begin{tabular}{|c|c|c|c|c|c|c|c|c|c|c|c|c|c|c|c|}
\hline \multirow{3}{*}{$\begin{array}{c}\omega \\
(\mathrm{rpm})\end{array}$} & \multirow{3}{*}{$\begin{array}{l}|\phi| \\
(\%)\end{array}$} & \multirow[t]{3}{*}{$\lambda$} & \multirow{3}{*}{$\begin{array}{l}\text { Ignição } \\
{ }^{\circ} \text { APMS }\end{array}$} & \multirow{3}{*}{$\begin{array}{c}\tau \\
(\mathrm{Nm})\end{array}$} & \multirow{3}{*}{$\begin{array}{c}\mathrm{P} \\
(\mathrm{kW})\end{array}$} & \multirow{3}{*}{$\begin{array}{c}\eta \\
(\%)\end{array}$} & \multicolumn{2}{|l|}{ Pressão } & \multirow{3}{*}{$\begin{array}{c}\text { Consumo } \\
\text { etanol } \\
(\mathrm{g} / \mathrm{s})\end{array}$} & \multirow{2}{*}{\multicolumn{2}{|c|}{$\begin{array}{c}\text { Razão A/C } \\
\text { calculada }\end{array}$}} & \multirow{3}{*}{$\begin{array}{c}\text { Vazão } \mathrm{H}_{2} \mathrm{O} \\
\text { estimada } \\
(\mathrm{g} / \mathrm{s})\end{array}$} & \multicolumn{3}{|c|}{ Balanço de carbono $(\mathrm{g} / \mathrm{s})$} \\
\hline & & & & & & & \multirow{2}{*}{$\begin{array}{c}\text { MAP } \\
(\mathrm{mmHg})\end{array}$} & \multirow{2}{*}{$\begin{array}{c}\text { Caldeira } \\
(\mathrm{kPa})\end{array}$} & & & & & Entr. & Saída & dif. \\
\hline & & & & & & & & & & $\Lambda$ & $\lambda$ & & & & $(\%)$ \\
\hline 2000 & 24,25 & 1,00 & 21,4 & 36,77 & 7,70 & 28,2 & 493,6 & 151,6 & 1,10 & 8,16 & 0,98 & 296,9 & 0,53 & 0,48 & 8,89 \\
\hline 2000 & 26,25 & 1,01 & 19,8 & 37,66 & $\begin{array}{l}7,89 \\
\end{array}$ & 30,4 & 503,6 & 166,3 & 1,04 & 8,59 & 1,03 & 362,5 & 0,51 & 0,49 & 3,77 \\
\hline 2000 & 41,25 & 1,19 & 17,4 & 49,86 & 10,44 & 34,3 & 626,7 & 166,2 & 1,22 & 10,08 & 1,21 & 270,5 & 0,59 & 0,57 & 3,52 \\
\hline 2000 & 57,75 & 1,30 & 18,9 & 46,99 & 9,84 & 30,6 & 634,7 & 161,3 & 1,29 & 9,99 & 1,20 & 314,6 & 0,63 & 0,56 & 10,32 \\
\hline 2000 & 35,50 & 1,36 & 19,5 & 40,17 & 8,41 & 29,9 & 624,1 & 156,3 & 1,13 & 10,65 & 1,28 & 306,1 & 0,55 & 0,51 & 7,74 \\
\hline 2000 & 40,50 & 1,48 & 21,7 & 38,02 & 7,96 & 29,3 & 655,1 & 151,4 & 1,09 & 12,00 & 1,44 & 221,3 & 0,53 & 0,51 & 4,08 \\
\hline 2000 & 53,00 & 1,01 & 13,9 & 58,29 & 12,21 & 30,7 & 673,6 & 151,3 & 1,60 & 7,91 & 0,95 & 324,5 & 0,78 & 0,67 & 13,32 \\
\hline 2000 & 100,00 & 1,01 & 13,4 & 57,93 & 12,13 & 30,9 & 683,6 & 151,3 & 1,57 & 8,10 & 0,97 & 348,9 & 0,76 & 0,68 & 10,40 \\
\hline 3000 & 24,50 & 1,01 & 26,9 & 22,24 & 6,99 & 23,5 & 355,4 & 161,1 & 1,19 & 8,16 & $\overline{0,98}$ & 484,2 & 0,58 & 0,52 & 9,31 \\
\hline 3000 & 30,75 & 1,23 & 29,1 & 24,57 & 7,72 & 25,9 & 412,4 & 161,1 & 1,20 & 9,89 & 1,19 & 485,4 & 0,58 & 0,53 & 8,56 \\
\hline 3000 & 31,75 & 1,31 & 24,7 & 25,11 & 7,89 & 26,0 & 438,4 & 164,1 & 1,22 & 10,50 & 1,26 & 371,6 & 0,59 & 0,54 & 8,93 \\
\hline 3000 & 32,25 & 1,39 & 24,1 & 26,18 & 8,23 & 26,7 & 463,4 & 166,0 & 1,24 & 10,96 & 1,32 & 376,7 & 0,60 & 0,55 & 7,74 \\
\hline 3000 & 53,00 & 1,01 & 15,6 & 60,80 & 19,10 & 32,8 & 661,8 & 151,8 & 2,34 & 8,77 & 1,05 & 517,4 & 1,13 & 1,11 & 2,13 \\
\hline 3000 & 100,00 & 1,02 & 14,9 & 60,98 & 19,16 & 33,1 & 676,8 & 151,8 & 2,33 & 8,94 & 1,07 & 436,4 & 1,13 & 1,10 & 2,19 \\
\hline 3000 & 100,00 & 1,22 & 14,5 & 49,68 & 15,61 & 30,3 & 676,8 & 141,9 & 2,07 & 10,36 & 1,24 & 504,8 & 1,01 & 0,97 & 3,36 \\
\hline 3000 & 100,00 & 1,41 & 17,1 & 39,63 & 12,45 & 27,8 & 676,8 & 134,1 & 1,80 & 11,61 & 1,39 & 548,3 & 0,87 & 0,84 & 3,44 \\
\hline 4000 & 24,50 & 1,00 & 22,3 & 11,84 & 4,96 & 16,8 & 256,0 & 151,7 & 1,19 & 8,77 & 1,05 & 722,1 & 0,58 & 0,56 & 2,13 \\
\hline 4000 & 29,25 & 1,14 & 22,2 & 13,09 & 5,48 & 18,6 & 296,0 & 154,6 & 1,18 & 10,24 & 1,23 & 412,1 & 0,57 & 0,59 & $-3,01$ \\
\hline 4000 & 33,75 & 2,00 & 31,4 & 8,97 & 3,76 & 11,8 & 396,8 & 159,6 & 1,27 & 14,28 & 1,71 & 517,6 & 0,62 & 0,50 & 19,61 \\
\hline 4000 & 32,25 & 1,22 & 19,2 & 12,55 & 5,26 & 14,5 & 346,8 & 156,7 & 1,46 & 9,91 & 1,19 & 506,8 & 0,71 & 0,63 & 10,23 \\
\hline 2000 & 54,00 & 1,06 & 17,3 & 53,62 & 11,23 & 30,6 & 675,4 & 151,6 & 1,47 & 8,58 & 1,03 & 326,2 & 0,71 & 0,65 & 9,37 \\
\hline 4000 & 52,00 & 1,37 & 25,8 & 47,17 & 19,76 & 30,7 & 646,0 & 156,6 & 2,59 & 11,24 & 1,35 & 630,2 & 1,25 & 1,18 & 5,82 \\
\hline 4000 & 99,25 & 1,51 & 21,3 & 39,81 & 16,68 & 27,0 & 666,0 & 151,7 & 2,48 & 12,47 & 1,50 & 672,6 & 1,21 & 1,18 & 2,36 \\
\hline 4000 & 53,00 & 1,22 & 19,1 & 52,01 & 21,79 & 30,4 & 646,0 & 166,4 & 2,88 & 10,02 & 1,20 & 702,0 & 1,40 & 1,29 & 7,75 \\
\hline 4000 & 47,50 & 1,07 & 15,7 & 50,75 & 21,26 & 29,6 & 626,0 & 171,3 & 2,88 & 9,58 & 1,15 & 638,9 & 1,40 & 1,36 & 2,48 \\
\hline 4000 & 42,50 & 1,01 & 15,0 & 49,32 & 20,66 & 28,5 & 591,0 & 181,1 & 2,91 & 8,41 & 1,01 & 417,2 & 1,41 & 1,33 & 5,63 \\
\hline
\end{tabular}

Continua 
Conclusão

\begin{tabular}{|c|c|c|c|c|c|c|c|c|c|c|c|c|c|c|c|}
\hline \multirow{2}{*}{$\begin{array}{c}\omega \\
(\mathrm{rpm})\end{array}$} & \multirow{2}{*}{$\begin{array}{l}|\phi| \\
(\%)\end{array}$} & \multirow[t]{2}{*}{$\lambda$} & \multirow{2}{*}{$\begin{array}{l}\text { Ignição } \\
{ }^{\circ} \text { APMS }\end{array}$} & \multirow{2}{*}{$\begin{array}{c}\tau \\
(\mathrm{Nm})\end{array}$} & \multirow{2}{*}{$\begin{array}{c}\mathrm{P} \\
(\mathrm{kW})\end{array}$} & \multirow{2}{*}{$\begin{array}{c}\eta \\
(\%)\end{array}$} & \multicolumn{2}{|l|}{ Pressão } & \multirow{2}{*}{$\begin{array}{c}\text { Consumo } \\
\text { etanol } \\
(\mathrm{g} / \mathrm{s})\end{array}$} & \multirow{2}{*}{\multicolumn{2}{|c|}{$\begin{array}{c}\text { Razão A/C } \\
\text { calculada }\end{array}$}} & \multirow{2}{*}{$\begin{array}{c}\text { Vazão } \mathrm{H}_{2} \mathrm{O} \\
\text { estimada } \\
(\mathrm{g} / \mathrm{s})\end{array}$} & \multicolumn{3}{|c|}{ Balanço de carbono $(\mathrm{g} / \mathrm{s})$} \\
\hline & & & & & & & $\begin{array}{c}\text { MAP } \\
(\mathrm{mmHg})\end{array}$ & $\begin{array}{c}\text { Caldeira } \\
(\mathrm{kPa})\end{array}$ & & & & & Entr. & Saída & $\begin{array}{l}\text { dif. } \\
(\%)\end{array}$ \\
\hline 2000 & 60,75 & 1,11 & 8,5 & 45,91 & 9,62 & 28,6 & 675,8 & 146,7 & 1,35 & 9,76 & 1,17 & 366,2 & 0,66 & 0,67 & $-2,44$ \\
\hline 3000 & 55,75 & 1,31 & 23,0 & 49,68 & 15,61 & 31,3 & 665,8 & 141,8 & 2,00 & 10,81 & 1,30 & 488,0 & 0,97 & 0,93 & 4,31 \\
\hline 3000 & 100,00 & 1,24 & 20,0 & 52,19 & 16,40 & 32,9 & 675,8 & 146,7 & 2,00 & 10,78 & 1,29 & 488,4 & 0,97 & 0,98 & $-1,22$ \\
\hline 4000 & 67,00 & 1,47 & 30,1 & 43,40 & 18,18 & 30,7 & 665,8 & 151,6 & 2,38 & 12,86 & 1,54 & 526,3 & 1,15 & 1,17 & $-1,40$ \\
\hline $3000^{\star}$ & 100,00 & 1,00 & 17,8 & 65,46 & 20,56 & 32,3 & 685,4 & 166,3 & 2,56 & 8,41 & 1,01 & 2079,9 & 1,24 & 1,18 & 5,09 \\
\hline $2000^{\star}$ & 100,00 & 0,99 & 25,8 & 55,60 & 11,64 & 30,9 & 685,0 & 92,7 & 1,51 & 8,89 & 1,07 & - & 0,73 & 0,72 & 1,49 \\
\hline
\end{tabular}

$\star$ Regimes operados com injeção de combustível líquido (ECU Fueltech), para efeito de comparação.

$|\phi|$ Abertura da válvula borboleta. 


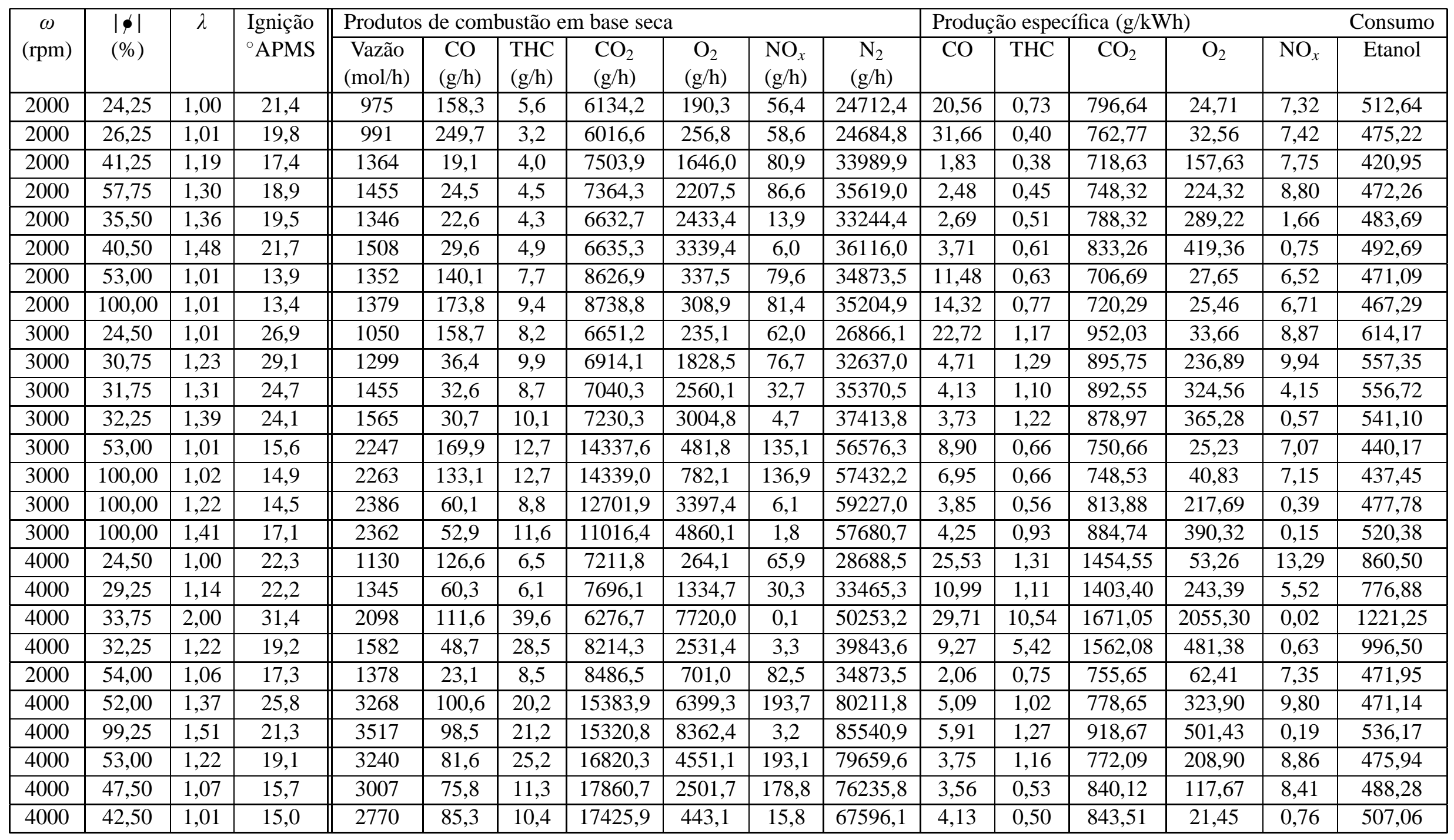

\section{Continua}


Conclusão

\begin{tabular}{|c|c|c|c|c|c|c|c|c|c|c|c|c|c|c|c|c|}
\hline \multirow{2}{*}{$\begin{array}{c}\omega \\
(\mathrm{rpm})\end{array}$} & \multirow{2}{*}{$\begin{array}{l}|\phi| \\
(\%)\end{array}$} & \multirow[t]{2}{*}{$\lambda$} & \multirow{2}{*}{$\begin{array}{l}\text { Ignição } \\
{ }^{\circ} \text { APMS }\end{array}$} & \multicolumn{7}{|c|}{ Produtos de combustão em base seca } & \multicolumn{5}{|c|}{ Produção específica (g/kWh) } & Consumo \\
\hline & & & & $\begin{array}{c}\text { Vazão } \\
(\mathrm{mol} / \mathrm{h})\end{array}$ & $\begin{array}{c}\mathrm{CO} \\
(\mathrm{g} / \mathrm{h})\end{array}$ & $\begin{array}{l}\text { THC } \\
(\mathrm{g} / \mathrm{h})\end{array}$ & $\begin{array}{l}\mathrm{CO}_{2} \\
(\mathrm{~g} / \mathrm{h})\end{array}$ & $\begin{array}{c}\mathrm{O}_{2} \\
(\mathrm{~g} / \mathrm{h})\end{array}$ & $\begin{array}{l}\mathrm{NO}_{x} \\
(\mathrm{~g} / \mathrm{h})\end{array}$ & $\begin{array}{c}\mathrm{N}_{2} \\
(\mathrm{~g} / \mathrm{h})\end{array}$ & $\mathrm{CO}$ & THC & $\mathrm{CO}_{2}$ & $\mathrm{O}_{2}$ & $\mathrm{NO}_{x}$ & Etanol \\
\hline 2000 & 60,75 & 1,11 & $\overline{8,5}$ & 1502 & 29,4 & 12,0 & 8792,1 & 956,7 & 86,7 & 36419,8 & 3,06 & 1,24 & 914,35 & 99,50 & $\overline{9,02}$ & 506,20 \\
\hline 2000 & 0,00 & & & 1486 & 33,3 & 12,9 & 8698,1 & 170,1 & 87,8 & 36861 & 3,40 & 1,31 & 887,25 & 119,35 & 8,96 & 500,29 \\
\hline 3000 & 75 & 1,31 & 23,0 & 2397 & 53,7 & 21,9 & 12127,7 & 4057,3 & 141,9 & 59779,2 & 3,44 & 1,41 & 777,08 & 259,97 & 9,09 & 461,89 \\
\hline 3000 & 0,00 & 1,24 & 20,0 & 2438 & 47,8 & 15,3 & 12874,7 & 3277,2 & 144,1 & 59641,2 & 2,91 & 0,93 & 785,26 & 199,88 & 8,79 & 440,03 \\
\hline 4000 & 67,00 & 1,47 & 30,1 & 3475 & 97,3 & 50,3 & 15135,9 & 8205,9 & 51,3 & 84353,6 & 5,35 & 2,76 & 832,58 & 451,38 & 2,82 & 470,36 \\
\hline 2000 & 100,00 & 0,86 & 19,6 & 1311 & 2562,9 & 2,6 & 6404,7 & 79,7 & 11,8 & 35315,3 & 220,11 & 0,23 & 550,05 & 6,85 & 1,01 & 586,89 \\
\hline 3000 & 100,00 & 0,95 & 15,8 & 2267 & 1301,3 & 14,4 & 13566,5 & 188,6 & 133,3 & 57183,7 & 66,75 & 0,74 & 695,92 & 9,68 & 6,84 & 455,97 \\
\hline $3000^{\star}$ & 100,00 & 1,00 & 17,8 & 2360 & 376,6 & 7,2 & 14950,8 & 339,8 & 137,8 & 59447,9 & 18,31 & 0,35 & 727,01 & 16,52 & 6,70 & 448,17 \\
\hline $2000^{\star}$ & 100,00 & 0,99 & 25,8 & 1480 & 66,3 & 47,2 & 9311,7 & 440,4 & 88,3 & 37137,7 & 5,69 & 4,05 & 799,70 & 37,82 & 7,58 & 467,73 \\
\hline
\end{tabular}

$\star$ Regimes operados com injeção de combustível líquido (ECU Fueltech), para efeito de comparação. 


\subsection{Discussão}

Observou-se através das janelas do gerador de vapor que o combustível adquiriu uma cor amarelada, apesar da ausência de cor característica do etanol hidratado fornecido. A análise de amostra de combustível, através da espectometria de absorção atômica, indicou a presença de $1 \mathrm{ppm}$ de cobre e $20 \mathrm{ppb}$ de ferro, provavelmente proveinentes do contato com esses metais no gerador de vapor.

Entre o tubo encamisado e o Venturi oco há um pedaço de mangueira plástica reforçada transparente, com aproximadamente $20 \mathrm{~mm}$ livres para observação do fluxo de combustível. Durante os ensaios dinamométricos não se notou a presença de líquido nesse local, indicando que o motor é alimentado com vapor saturado ou superaquecido. O nível do combustível na caldeira manteve-se num patamar seguro, formando bolhas que estouravam-se a aproximadamente $25 \mathrm{~mm}$ de altura em relação ao nível do combustível. Com o nível a aproximadamente $40 \mathrm{~mm}$ do topo da câmara destinada à vaporização do etanol, não houve risco de transporte de combustível líquido para o coletor de admissão.

Não se pode usar o diagrama pressão-entalpia do etanol (figura 3.2) para saber o estado do vapor porque sua pressão e temperatura foram medidas em locais diferentes (na caldeira e após a válvula gaveta, respectivamente).

Alguns regimes apresentam diferenças grosseiras no balanço entre taxa de carbono que entra e sai do motor, devido a vazamentos e imprecisões nos instrumentos de medição.

Detalhes construtuvos do gerador de vapor e de outros acessórios utilizados estão no Apêndice D.

\subsubsection{Marcha lenta}

Buscou-se uma marcha-lenta estável, através do regime de 920rpm, 0,00\% de abertura de borboleta, $\lambda=1,00$ e avanço de ignição de 6,5 graus APMS; com combustível vaporizado. Doravante os regimes serão caracterizados por esses quatro pararâmetros, colocados nessa ordem e entre parênteses, por exemplo $(920 / 0,00 / 1,00 / 6,5)$ para referir-se ao regime de marcha-lenta referido neste parágrafo. Não foi possível, porém, mantê-lo por muito tempo, devido a grandes oscilações na temperatura de entrada da água, cuja estabilidade é fundamental para manter o motor em regime permanente. Há apenas o registro das emissões, onde nota-se uma emissão muito maior de THC com combustível vaporizado (1168ppm contra 296ppm) e um índice menor de CO $(0,16 \%$ contra $0,42 \%)$. 


\subsubsection{Regimes intermediários}

Para o regime de 2000 rpm e abertura da borboleta de aceleração a $23^{\circ}(24,25 \%)$ buscou-se recuperar o torque original de $37,7 \mathrm{Nm}$. Os regimes estudados no etanol vaporizado para comparação com esse regime original, de $(2000 / 26,25 / 1,01 / 19,8)$ a $(2000 / 40,50 / 1,48 / 21,7)$, ofereceram torques e rendimentos maiores, enquanto o primeiro regime estudado $(2000 / 24,25 / 1,00 / 21,4)$ ofereceu o mesmo torque $(37,7 \mathrm{Nm})$ com praticamente o mesmo rendimento. O regime $(2000 / 41,25 /$ $1,19 / 17,4)$ foi o que ofereceu o máximo rendimento $(34,3 \%)$ entre todos os que foram realizados com etanol vaporizado. Um aumento de eficiência na faixa $1,1 \leq \lambda \leq 1,2$ é normal para qualquer sistema de injeção de combustível e vem acompanhado de maiores emissões de óxidos de nitrogênio. Neste caso foi possível uma redução mais intensa das emissões de $\mathrm{NO}_{x}$ com valores de $\lambda$ a partir de 1,35. De qualquer forma não foi possível diminuir as emissões de THC em relação à alimentação original em nenhum caso. Se houvesse uma queima mais eficiente o rendimento poderia ser ainda melhor.

Como o regime $(2000 / 41,25 / 1,19 / 17,4)$ oferece um torque muito maior que aquele que serve de base para operação com ECU original $(49,8 \mathrm{Nm}$ contra $37,7 \mathrm{Nm})$, foi feita sua comparação com outro regime também ensaiado com a ECU original, (2000/34,6/0,97/17,6), que fornece aproximadamente o mesmo torque $(50,04 \mathrm{Nm})$. O regime alimentado com etanol vaporizado foi mais eficiente $(34,3 \%$ contra $27,1 \%)$ e conseguiu boas reduções nas emissões de CO e THC, restando as emissões de $\mathrm{NO}_{x}$ no mesmo patamar.

Para comparar com o regime de 2000 rpm e abertura da borboleta de aceleração a $45^{\circ}(52,50 \%)$ foram realizados os ensaios (2000/53,00/1,01/13,9), (2000/54,00/1,06/17,3), (2000/60,75/1,11/ $8,5)$ e $(2000 / 100,00 / 1,11 / 11,0)$. No primeiro houve queda de eficiência de cerca de $4,3 \%$ e aumento no torque na casa dos $1,5 \%$. A diminuição nas emissões de $\mathrm{CO}$ e THC foi muito maior que a perda de eficiência, porém as emissões de $\mathrm{NO}_{x}$ foram maiores. Nos outros regimes observa-se as mesmas tendências, com exceção da queda de torque em todas elas. Nota-se que entre o terceiro e o quarto regime estudados (com aberturas de borboleta de 60,75\% e 100,00\% respectivamente) há pouca diferença no torque, na eficiência e nas emissões específicas; visto que a taxa de admissão de ar é praticamente a mesma no final do curso da borboleta.

Para o regime de $3000 \mathrm{rpm}$ e abertura da borboleta de aceleração a $23^{\circ}(24,25 \%)$ foram realizados os ensaios de $(3000 / 24,50 / 1,01 / 26,9)$ a $(3000 / 32,25 / 1,39 / 24,1)$. O segundo ensaio dessa série $(3000 / 30,75 / 1,23 / 29,1)$ obteve o mesmo torque do regime analisado com alimentação original. Nele, observou-se aumento de 4,9\% na eficiência, às custas de elevações nas emissões de $\mathrm{NO}_{x}$ e THC. O próximo regime $(3000 / 31,75 / 1,31 / 24,7)$ porporciona ligeira redução nas emissões de THC e reduções mais drásticas de $\mathrm{CO}$ e $\mathrm{NO}_{x}$, com aumento de torque de 2,2\% e eficiência 5,3\% acima da original. O quarto regime, com abertura da válvula borboleta 1,50\% 
maior (de 30,75\% parar 32,25\%), levou a maiores valores de torque e eficiência que os outros, emitindo porém maiores quantidades de THC por unidade de energia entregue $(1,22 \mathrm{~g} / \mathrm{kWh}$ contr $1,11 \mathrm{~g} / \mathrm{kWh}$ ). A partir dessa abertura de borboleta de aceleração o funcionamento do motor ficou instável sem aumento no consumo de combustível. Devido ao aumento da emissão de THC nessa faixa de excesso de ar pode-se presumir que a chama começa a ficar instável nesse regime à medida que a razão ar/combustível normalizada aproxima-se de 1,4.

Outra comparação foi feita entre os regimes (3000/32,25/1,39/24,1)(vaporizado) e (3000/28,20/ 0,97/17,6)(ECU original), que têm a mesma combinação torque-rotação. Com maior abertura de válvula borboleta e excesso de ar de $39 \%$ houve aumento na eficiência e redução nas emissões específicas de 76,4\% para CO, 80,9\% para THC e 94,1\% para $\mathrm{NO}_{x}$.

Para o regime de $3000 \mathrm{rpm}$ e abertura da borboleta de aceleração a 45\%(52,50\%) o regime alimentado com combustível vaporizado $(3000 / 53,00 / 1,01 / 15,6)$ apresentou o mesmo torque $(60,8 \mathrm{Nm})$ com aumento na eficiência de 3,5\%. As emissões específicas de $\mathrm{NO}_{x}$ subiram $15,7 \%$ (menos que em outros regimes vaporizados estequiométricos) enquanto aquelas formadas pode combustíveis queimados incompletamente foram reduzidas. No próximo regime estudado $(3000 / 100,00 / 1,22 / 14,5)$ houve redução de aproximadamente $68 \%$ nas emissões específicas de $\mathrm{CO}$ e THC e de 93,6\% para $\mathrm{NO}_{x}$. Houve redução de torque de 18,3\% com manutenção da eficiência. O terceiro regime avaliado nesse caso $(3000 / 100,00 / 1,41 / 17,1)$ apresentou uma ligeira alta de THC e CO em relação ao anteior, indicando deficiências na propagação da chama. Houve também queda de eficiência $(-7,9 \%)$ e de torque $(-34,8 \%)$.

O último regime dessa série $(3000 / 55,75 / 1,31 / 23,0)$ apresentou menores quedas de eficiência ($1,3 \%)$, a mesma redução de torque do regime $(3000 / 100,00 / 1,22 / 14,5)$ e emissões de $\mathrm{NO}_{x}$ maiores. Pelo torque muito diferente daquele verificado no regime de referência com ECU original, ambos os regimes de 3000rpm/49,7Nm podem ser comparados com o regime (3000/35,9/0,97/ $15,9)$ realizado com ECU original. O regime (3000/100,00/1,22/14,5) manteve o mesmo patamar de eficiência com acentuada redução de emissões específicas, enquanto o regime (3000/ $55,75 / 1,31 / 23,0$ ) conseguiu aumento de aproximadamente $1,0 \%$ em eficiência às custas de emissão específica de $\mathrm{NO}_{x}$ 18,2\% acima daquela verificada com a mesma combinação torquerotação e ECU original.

Para o regime de 4000 rpm e abertura da borboleta de aceleração a $23^{\circ}(24,25 \%)$ foram ensaiados os regimes de $(4000 / 24,50 / 1,00 / 22,3)$ a $(4000 / 32,25 / 1,22 / 19,2)$. O primeiro regime ofereceu aumento de $10,0 \%$ em torque e $16,7 \%$ em eficiência, com aumento de 38,7\% na emissão específica de $\mathrm{NO}_{x}$. Nota-se que mesmo com mistura estequiométrica obtém-se aumento de rendimento, devido principalmente à queima mais completa e à liberação de energia da oxidação de parte do nitrogênio. O segundo regime estudado, (4000/29,25/1,14/22,2), obteve ganhos de 
torque e eficiência mais significativos e redução nas três categorias de emissões acompanhadas. O último regime dessa série $(4000 / 32,25 / 1,22 / 19,2)$ teve eficiência semelhante ao regime operado com a ECU original e maior emissão específica de THC, indicando que a inflexão da curva que relaciona essa emissão e a razão ar-combustível acontece com valores diferentes de $\lambda$ em cada regime, visto que em outros regimes as emissões de THC voltavam a aumentar com excesso de ar na cada dos 40\%. O regime anterior $(4000 / 33,75 / 2,00 / 31,4)$ mostra que é possível operar o MAPV até como dobro da quantidade de ar estequiométrica, mesmo que às custas de falhas na propagação de chama que são denunciadas pela baixa eficiência e pela alta quantidade de THC emitidos.

Para o regime de 4000 rpm e abertura da borboleta de aceleração a $45^{\circ}(52,50 \%)$ o torque foi menor (entre $10 \%$ e $20 \%$ ) em todos os regimes com alimentação de etanol vaporizado avaliados, de $(4000 / 52,00 / 1,37 / 25,8)$ a $(4000 / 42,50 / 1,01 / 15,0)$. A eficiência, entretanto, foi maior em todos eles (até 8,5\%). Em todos os regimes houve redução na emissão específica de $\mathrm{CO}$ em mais de $73 \%$, enquanto a emissão específica de THC caiu mais de $40 \%$. A emissão específica de $\mathrm{NO}_{x}$ cai no regime (4000/67,00/1,47/30,1), mantendo-se alta nos outros onde o excesso de ar é menor. Para aproximar-se da condição estequiométrica foi necessário fechar a válvula borboleta, porque o gerador de calor não pôde fornecer etanol vaporizado a taxa superior a 3,0g/s. Foram realizados os ensaios $(4000 / 47,50 / 1,07 / 15,0)$ e $(4000 / 42,5 / 1,01 / 15,0)$, incluídos na análise anterior. O último regime citado oferece eficiência de $28,5 \%$, na mesma faixa do regime original estudado, porém com emissões específicas muito menores.

O regime (4000/53,00/1,22/19,1) deve ser comparado com o regime $(4000 / 41,1 / 1,00 / 1,27)$, correspondente à mesma combinação torque-rotação na ECU original. O regime alimentado com combustível vaporizado apresentou maior rendimento (30,4\% contra $29,3 \%)$ e menores emissões específicas de CO e THC. A emissão específica de $\mathrm{NO}_{x}$ subiu 13,9\%.

Ordenando-se os regimes de funcionamento em ordem decrescente de eficiência, observa-se que os regimes que tiram melhor proveito da energia contida no combstível são os de 3000rpm com $|\phi|$ acima de $50 \%$, ocorrendo com valores de $\lambda$ entre 0,95 (não é comum um regime de mistura rica apresentar bom rendimento) e 1,31. O máximo rendimento foi alcançado por um regime que não obedece a esse padrão, sendo um caso isolado. 


\section{Emissões}

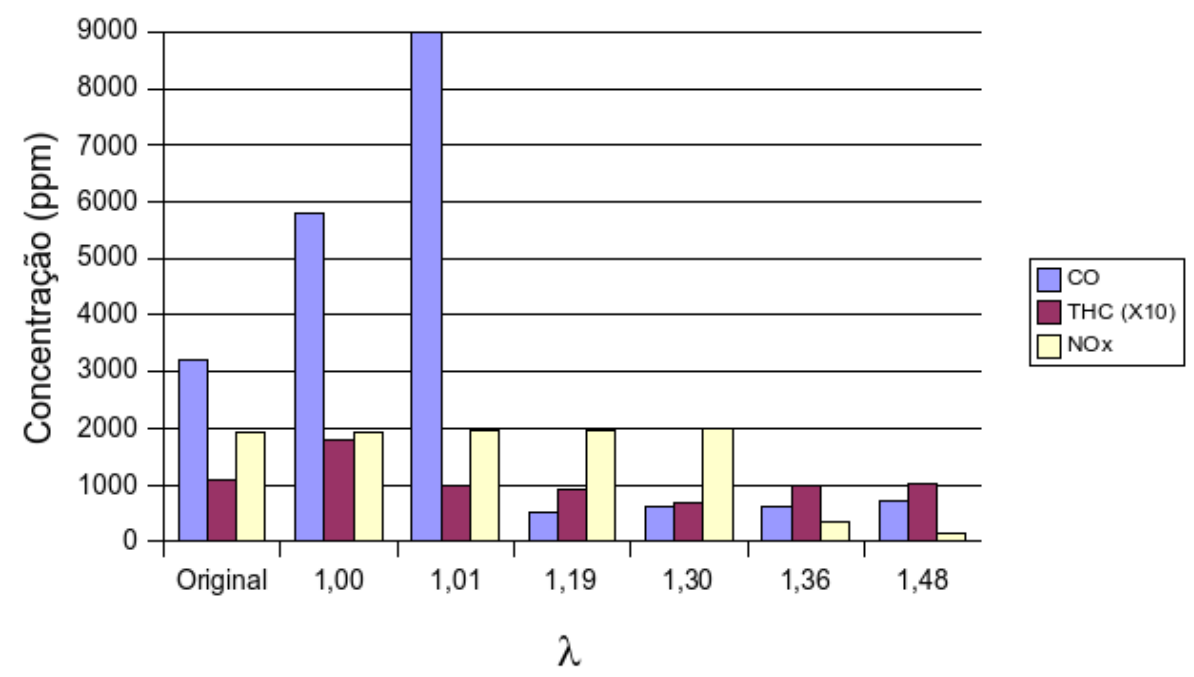

Figura 4.1: Emissões para regimes comparados com os de 2000rpm e 23\% de aceleração

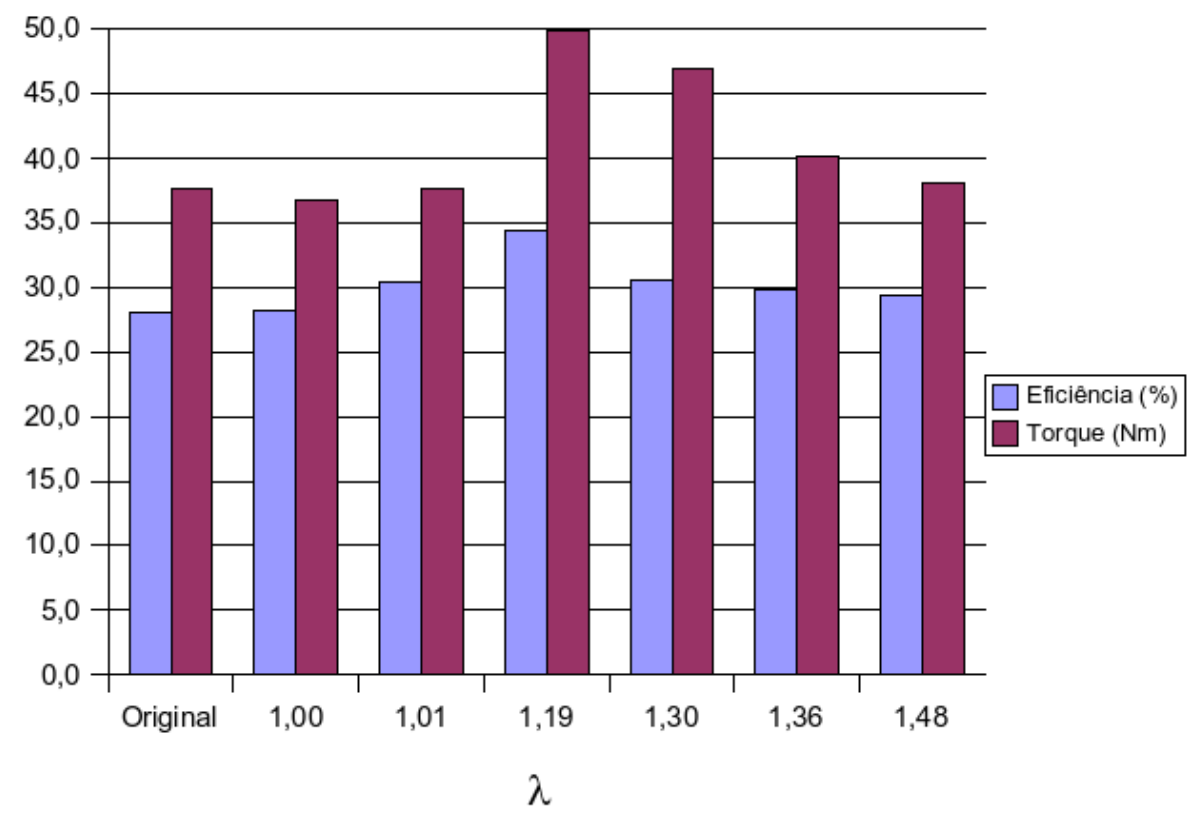

Figura 4.2: Torque e eficiência de regimes comparados com o de 2000rpm e 23\% de aceleração 


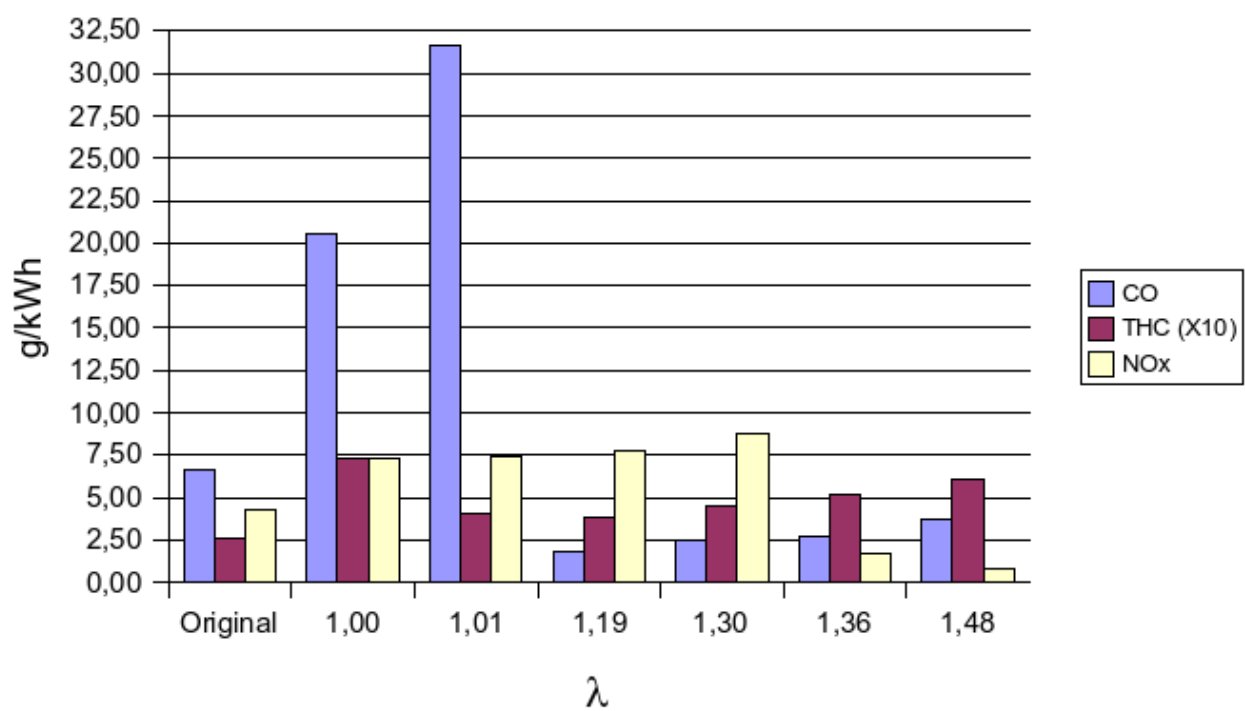

Figura 4.3: Emissões específicas para regimes comparados com o de 2000rpm e $23 \%$ de aceleração
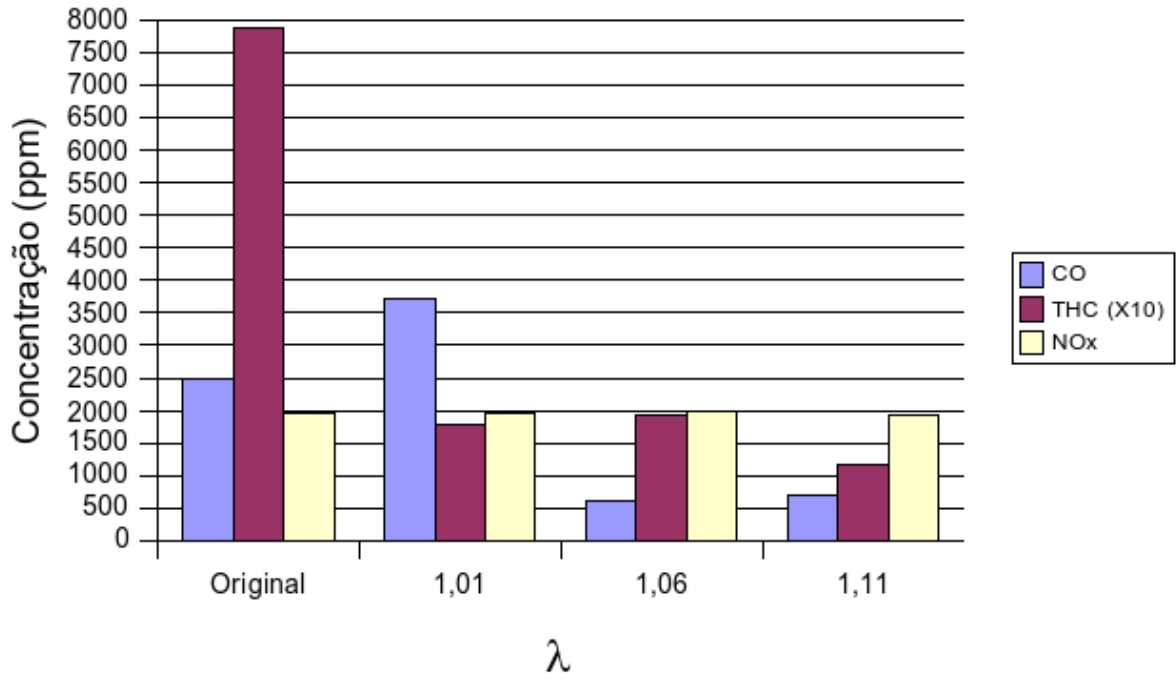

Figura 4.4: Emissões para regimes comparados com os de 2000rpm e 45\% de aceleração 


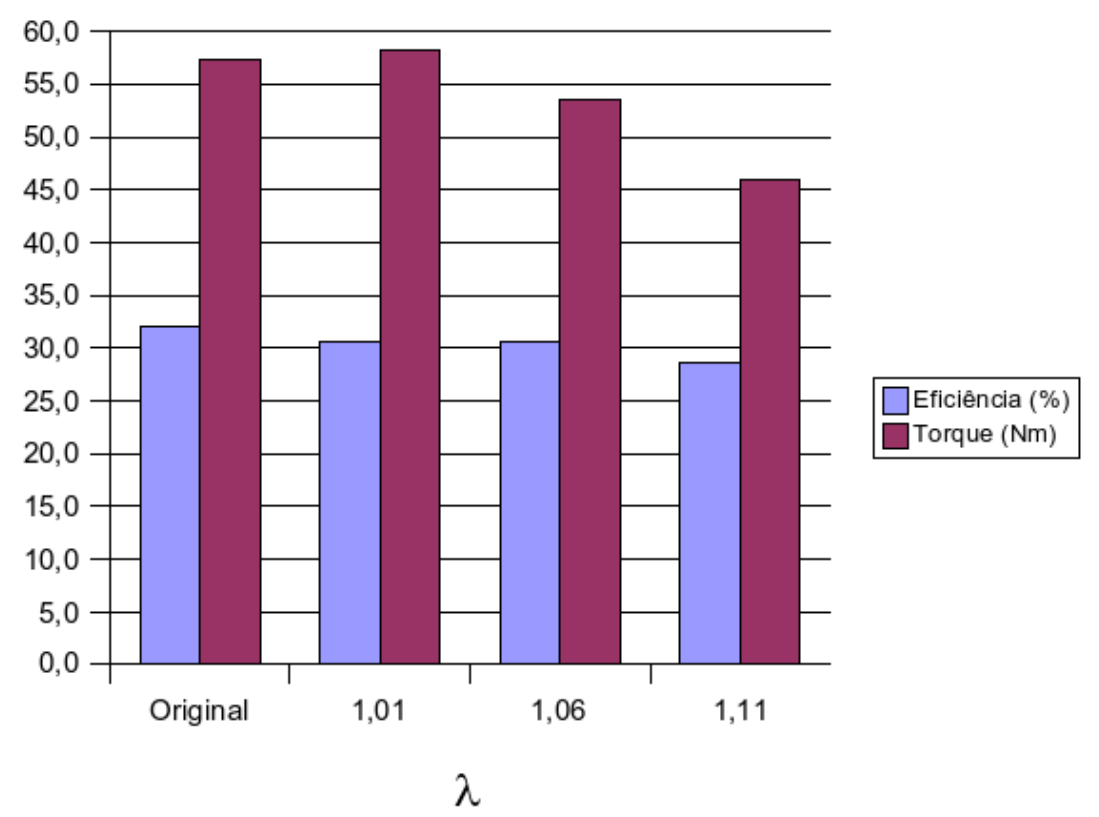

Figura 4.5: Torque e eficiência de regimes comparados com o de 2000rpm e 45\% de aceleração

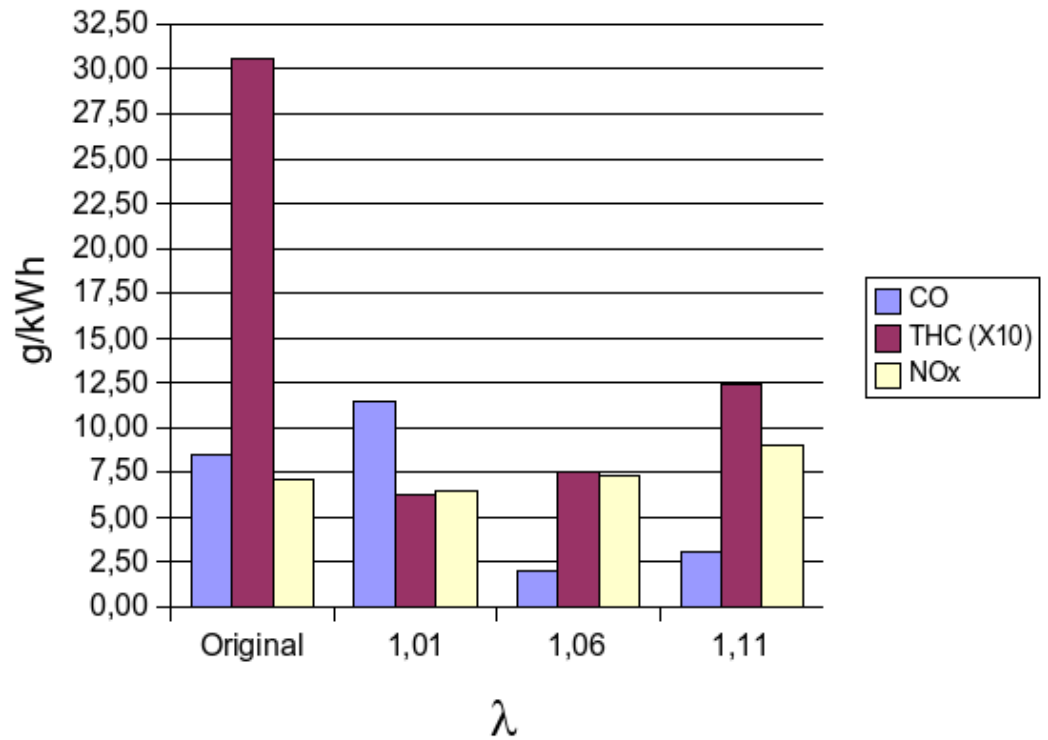

Figura 4.6: Emissões específicas para regimes comparados com o de $2000 \mathrm{rpm}$ e $45 \%$ de aceleração 


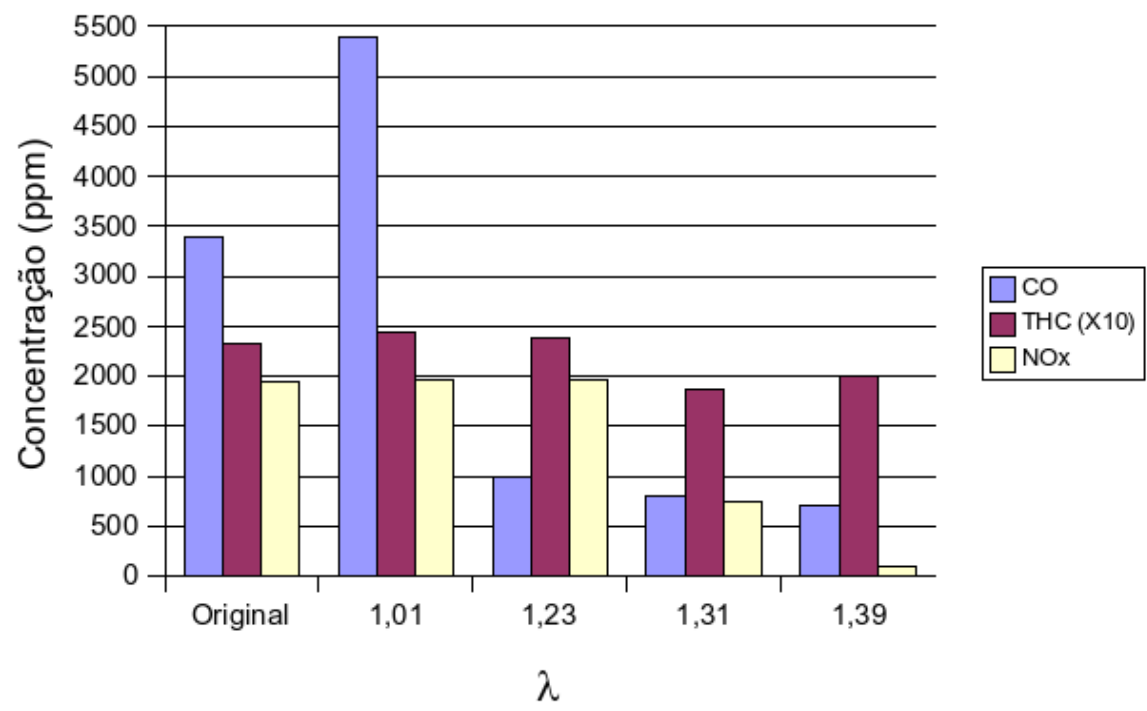

Figura 4.7: Emissões para regimes comparados com o de 3000rpm e 23\% de aceleração

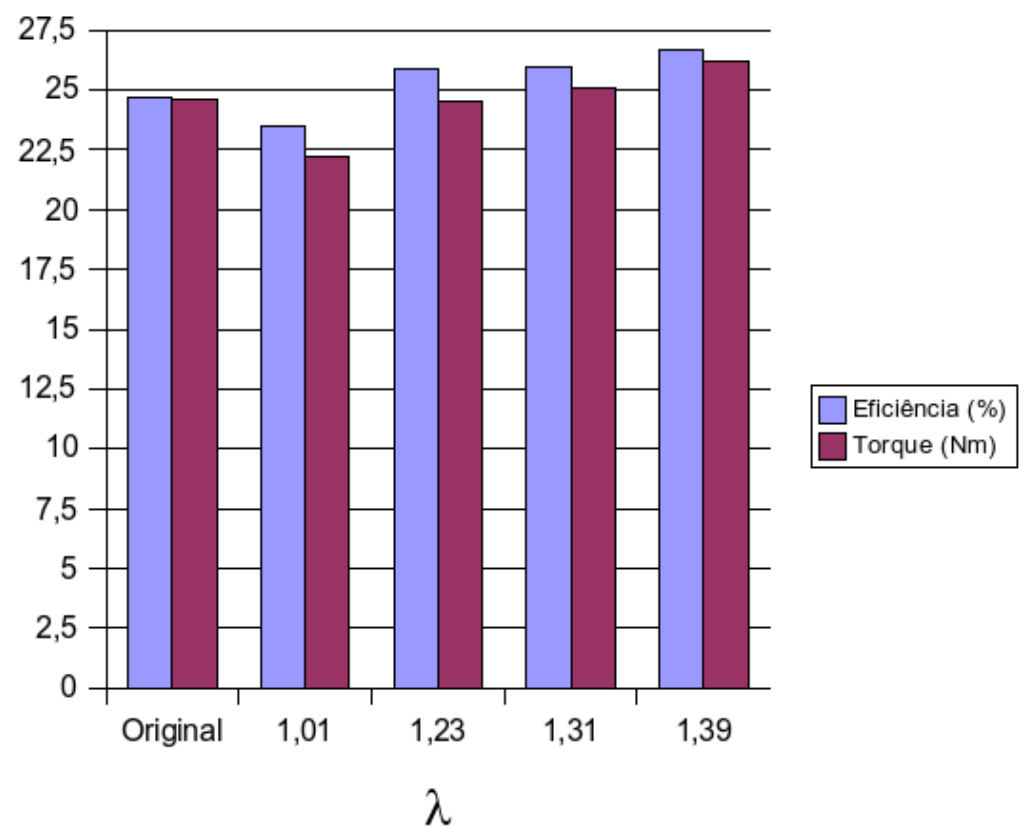

Figura 4.8: Torque e eficiência de regimes comparados com o de 3000rpm e $23 \%$ de aceleração 


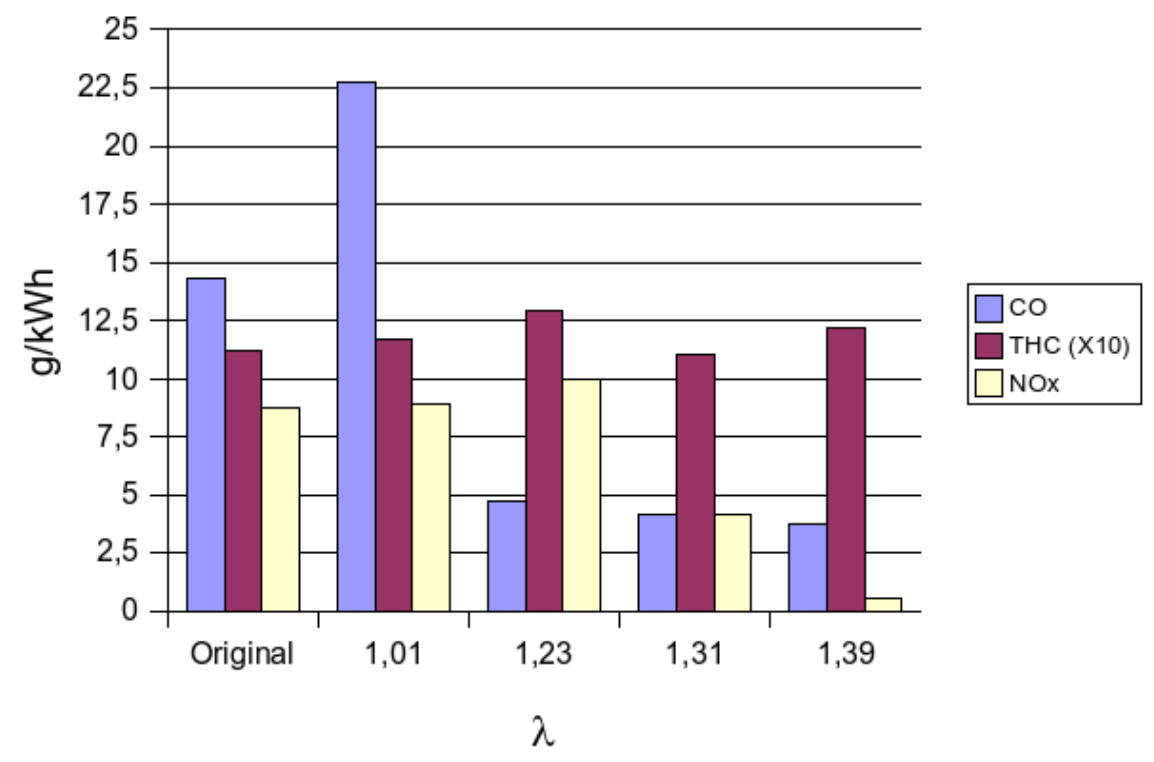

Figura 4.9: Emissões específicas para regimes comparados com o de 3000rpm e 23\% de aceleração

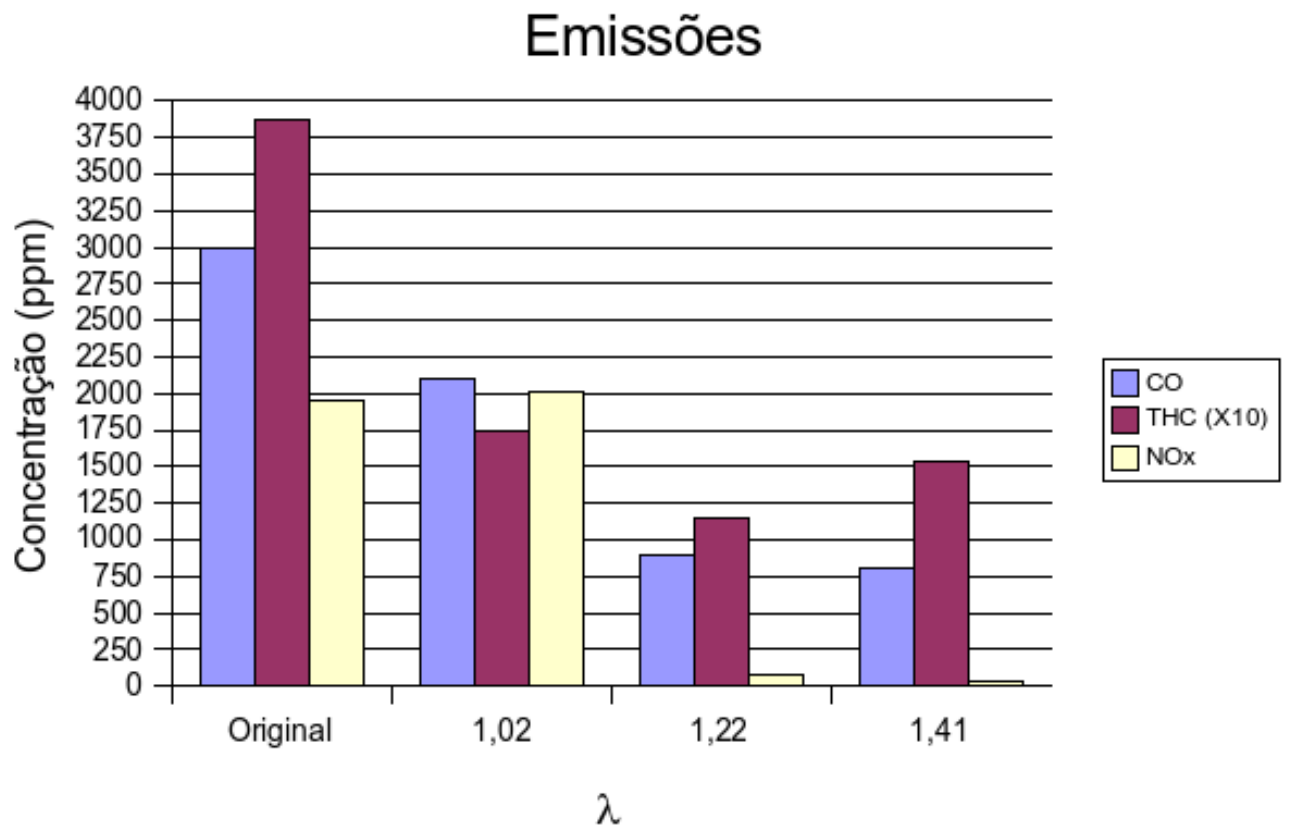

Figura 4.10: Emissões para regimes comparados com o de 3000rpm e 45\% de aceleração 


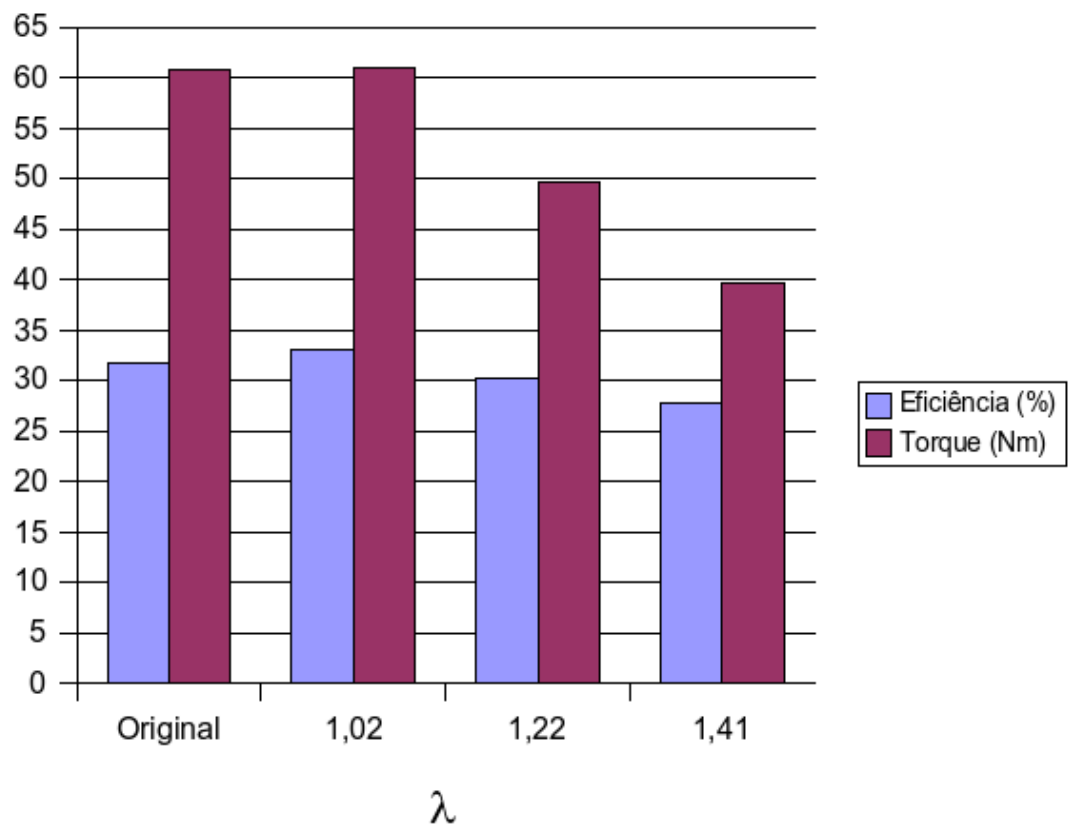

Figura 4.11: Torque e eficiência de regimes comparados com o de 3000rpm e 45\% de aceleração

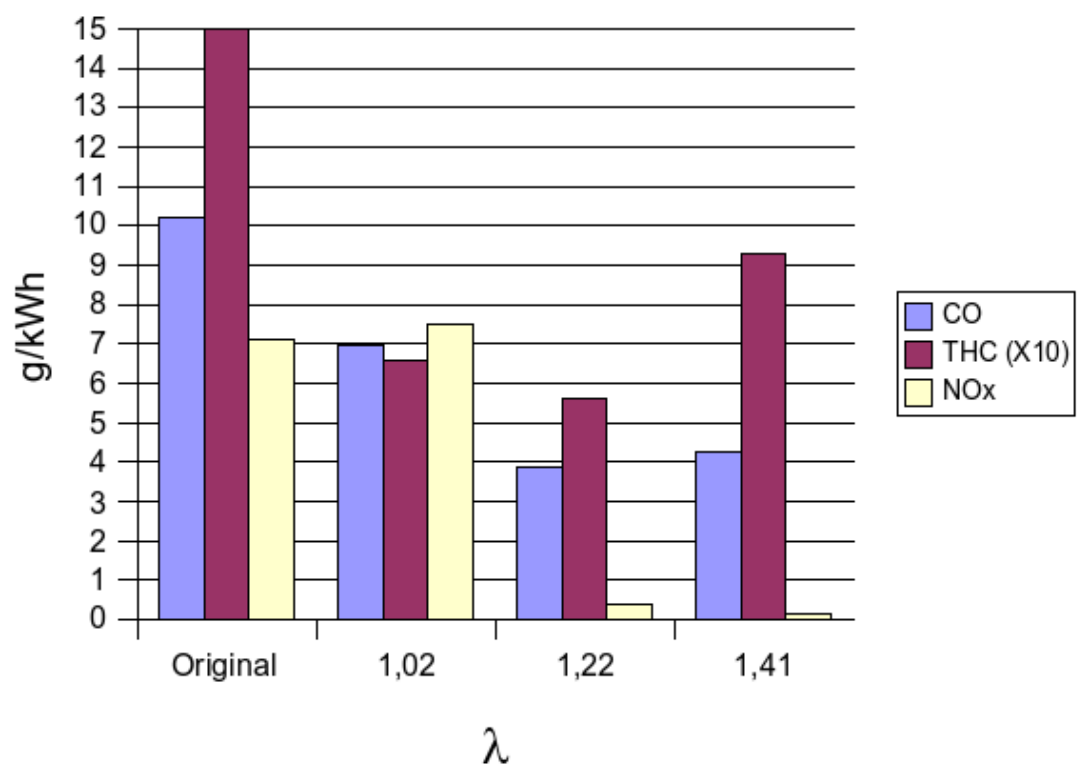

Figura 4.12: Emissões específicas para regimes comparados com o de 3000rpm e $45 \%$ de aceleração 


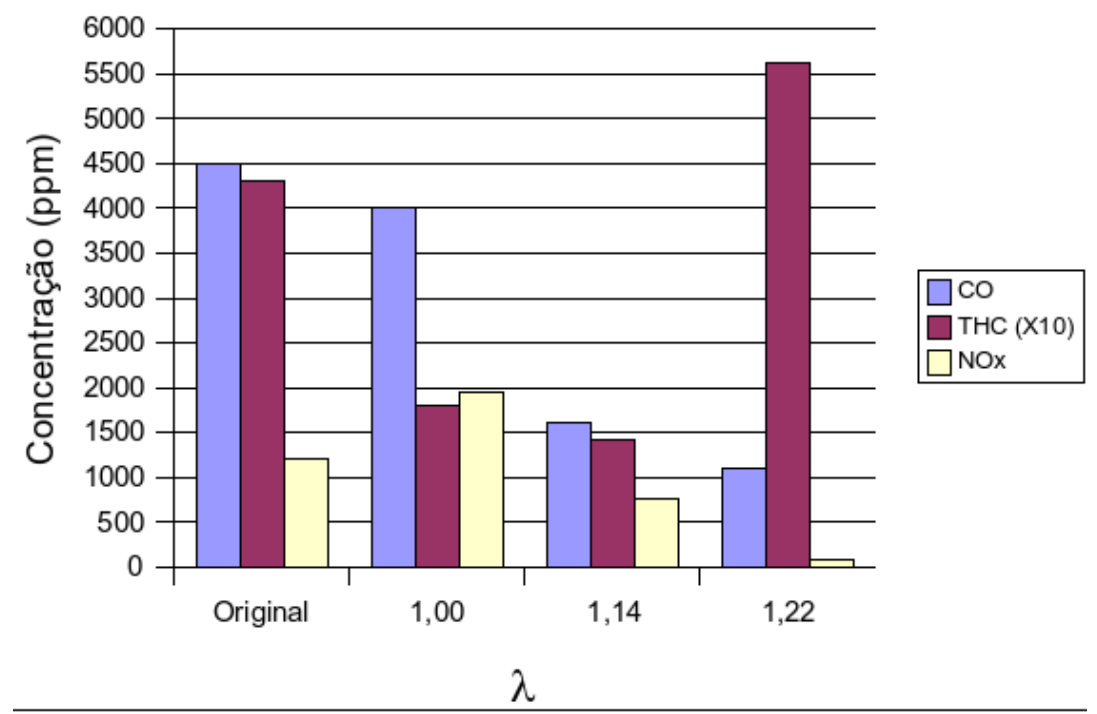

Figura 4.13: Emissões para regimes comparados com os de 4000rpm e 23\% de aceleração

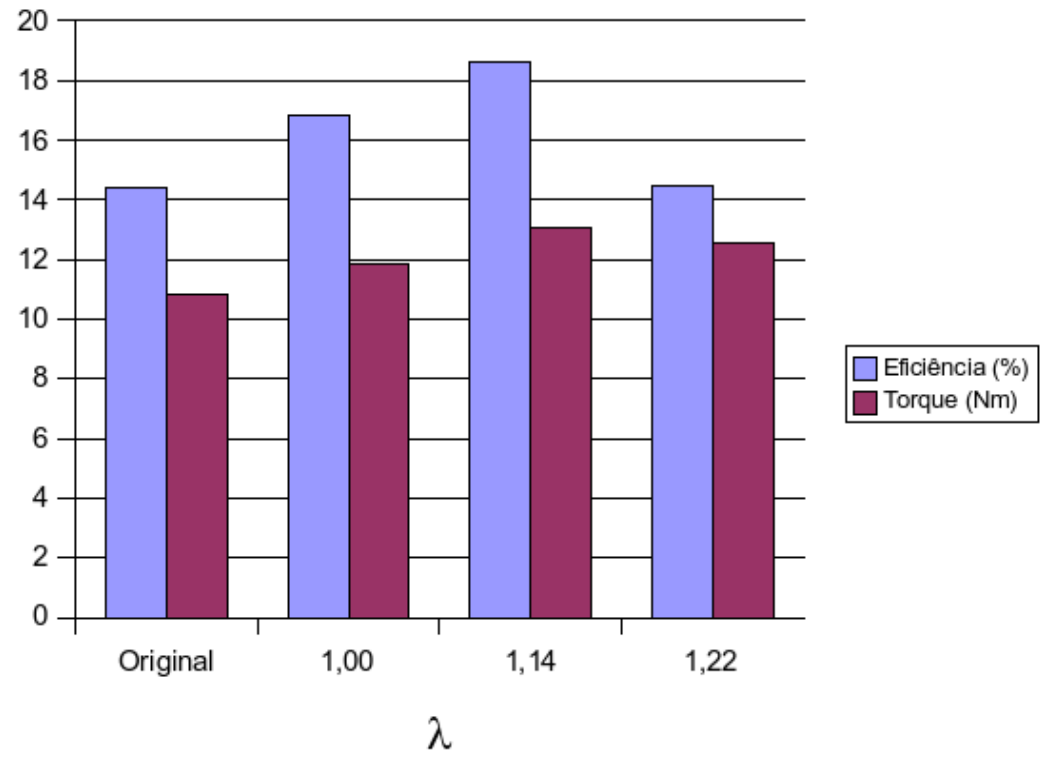

Figura 4.14: Torque e eficiência de regimes comparados com o de 4000rpm e $23 \%$ de aceleração 


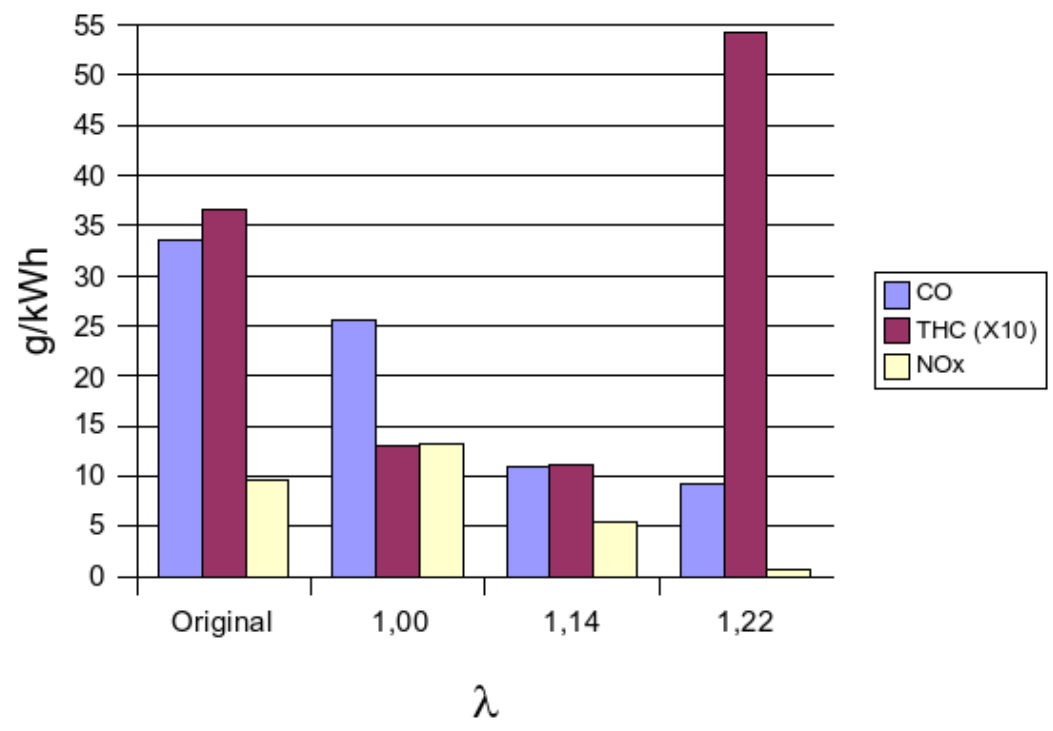

Figura 4.15: Emissões específicas para regimes comparados com o de 4000rpm e $23 \%$ de aceleração

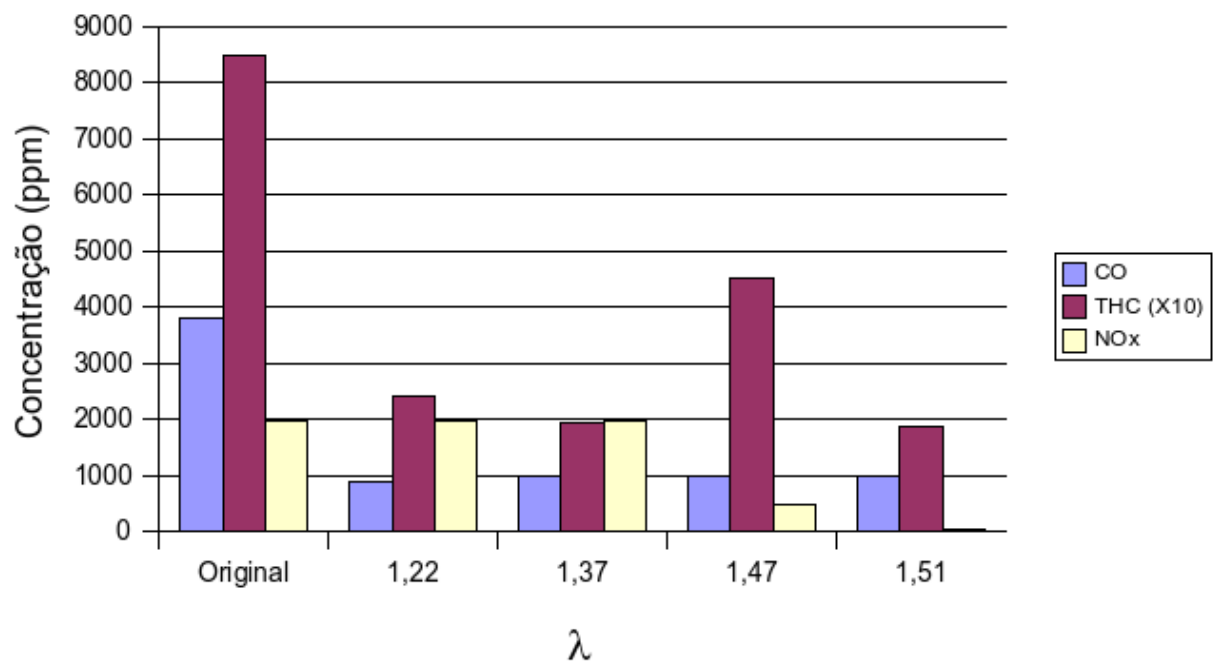

Figura 4.16: Emissões para regimes comparados com os de 4000rpm e 45\% de aceleração 


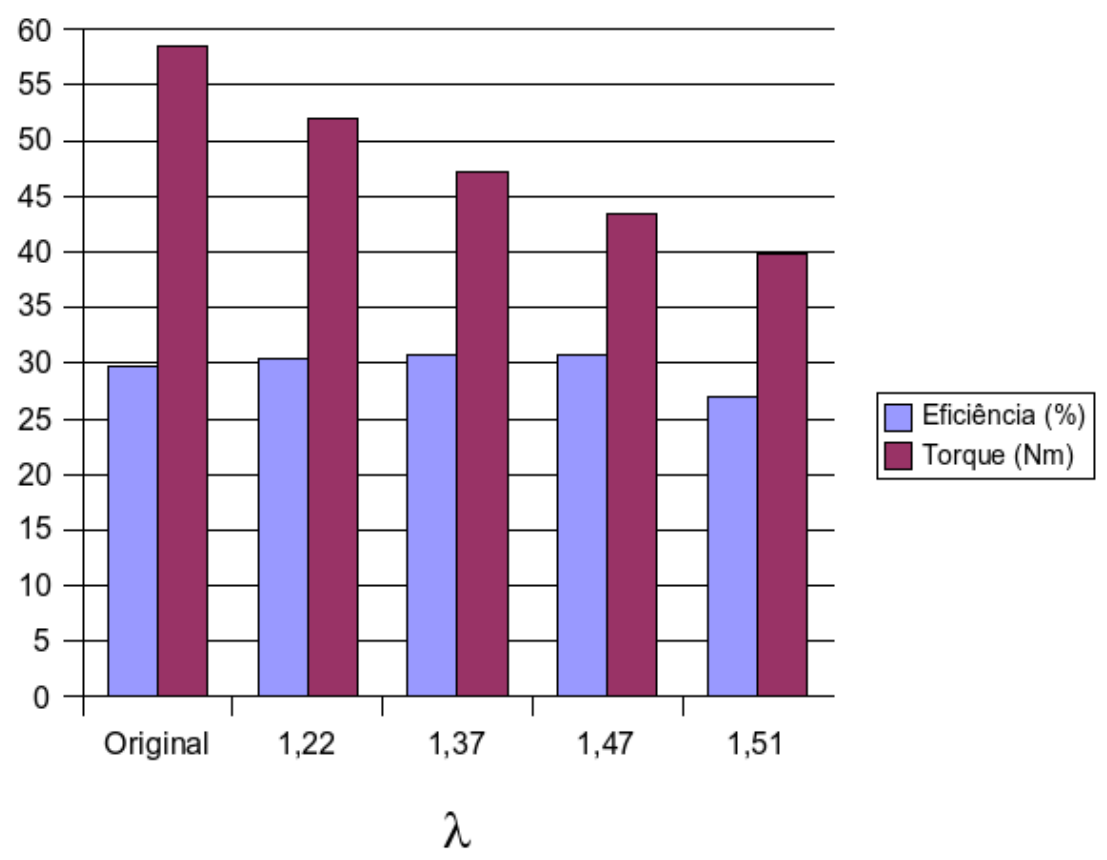

Figura 4.17: Torque e eficiência de regimes comparados com o de 4000rpm e 45\% de aceleração

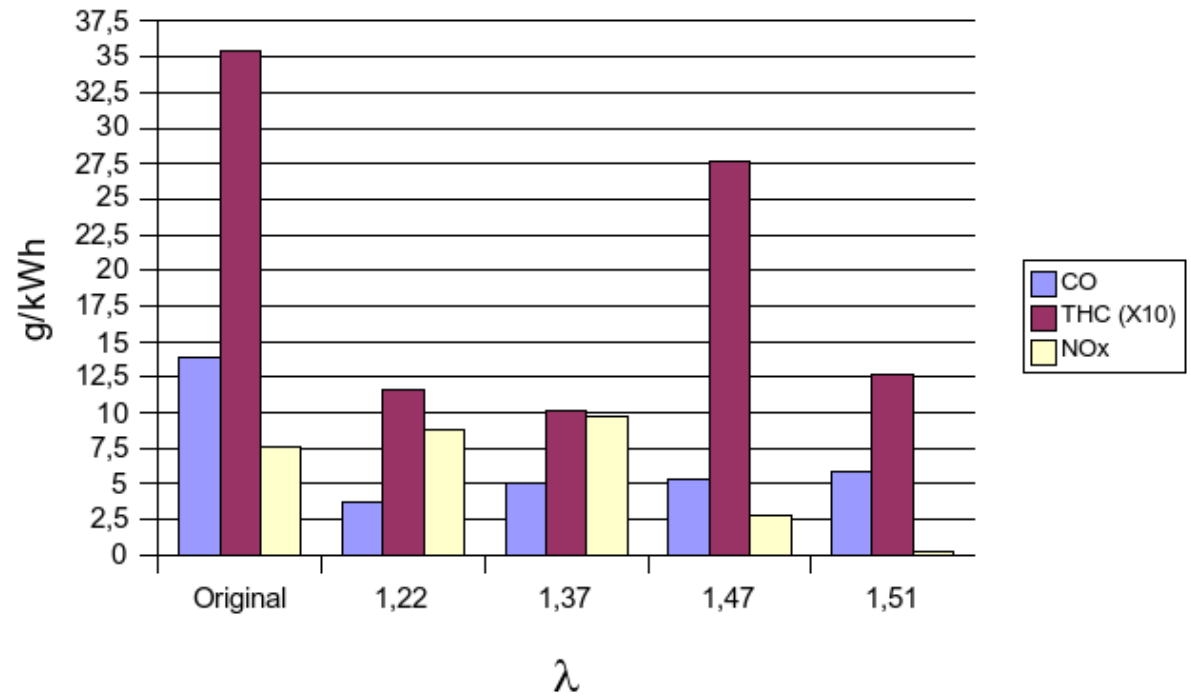

Figura 4.18: Emissões específicas para regimes comparados com o de 4000rpm e 45\% de aceleração 
A comparação entre os regimes de operação com combustível vaporizado e líquido em combinações próximas de torque e rotação geralmente oferece melhor rendimento nos regimes alimentados com vapor, especialmente quando se busca torque semelhante com maiores aberturas da borboleta de aceleração. Na maioria dos casos o aumento da eficiência deve-se à estabilidade de chama com misturas mais pobres que leva a menores perdas de carga através da válvula borboleta. Chegou-se a ter mais eficiência em regimes estequiométricos com vapor, ou seja, já se partia de eficiências maiores antes de se buscar o torque ou eficiência máximas com maiores aberturas para admissão de ar; o que indicia que parte do mérito deve-se à queima mais eficiente do combustível pré-vaporizado e misturado ao ar.

Em linhas gerais aumentos de eficiência levaram a maiores emissões específicas de $\mathrm{NO}_{x}$. Para se ter certeza de que elas assumem valores baixos é necessário ultrapassar os 35\% de excesso de ar. Conseguiu-se regimes com emissões abaixo da faixa entre 1900ppm e 2050ppm (que é a mesma observada com alimentação de combustível líquido) em outras faixas de excesso de ar, porém de forma irregular, sem um padrão estabalecido. Há ainda regimes com reduções drásticas de $\mathrm{NO}_{x}$ às custas de perda de rendimento. $\mathrm{O}$ ângulo de avanço da ignição mostrou influência na eficiência (maior com menores ângulos de queima) e nas emissões de $\mathrm{NO}_{x}$ (menores com atraso de ignição e menores picos de temperatura de chama). Isso foi percebido durante os ajustes em busca dos regimes que ofereceriam melhor torque, ou seja, não foram feitos ensaios com diversos ângulos mantendo-se as outras condições para avaliar esse efeito isoladamente. Poucos regimes conseguiram aumento de eficiência e redução nas três emissões avaliadas. Em alguns casos há redução de eficiência e redução muito maior nas emissões, ou ao menos redução brusca de $\mathrm{NO}_{x}$ que é a emissão mais difícil e de comportamento mais irregular. A falta do efeito refrigerante causado pela vaporização das bolhas de etanol líquido é uma das causas. Não há relação com o excesso de ar, com a temperatura medida no coletor de escape e nem com o tempo entre a ignição e o ponto morto superior.

Poucos regimes conseguiram reduzir as emissões específicas de $\mathrm{NO}_{x} \operatorname{com} \lambda<1$, 35. São eles 3000/100,00/1,22/14,5; 4000/32,25/1,22/19,2; 4000/29,25/1,14/22,2 e 4000/42,50/1,01/15,0. São regimes com várias faixas de torque, eficiência e consumo de ar, bem como elevadas temperaturas no coletor de escape. Para excesso de ar abaixo dos 35\%, outros regimes com 4000rpm apresentaram emissões de $\mathrm{NO}_{x}$ na faixa dos 2000ppm.

Um fator sabidamente favorável à diminuição dessa emissão é o atraso na ignição. Pares de regimes semelhantes em rotação, razão ar-combustível e consumo de ar (3000/100,00/1,22/14,5 e 3000/100,00/1,24/20,0; 4000/99,25/1,51/21,3 e 4000/67,00/1,47/30,1) apresentaram menores emissões de $\mathrm{NO}_{x}$ quando a ignição veio mais atrasada. A contrapartida é a queda no rendimento e no torque, conforme ilustrado na tabela ??. 
A emissão de CO é a mais fácil de conter, ficando abaixo de $0,11 \%$ em volume com um simples excesso de ar de 5\%. As emissões de THC ficam sob controle abaixo dos 300ppm (valores lidos pelo analisador de gases, sem correção), com poucas exceções, em misturas pobres. Essas leituras são mais baixas que aquelas observadas para o funcionamento com combustível líquido e ECU original, exceto para abertura de borboleta de $23^{\circ}$. Comparando-se regimes com alimentação líquida e vaporizada as emissões de THC caíram com menor facilidade. As emissões específicas, porém, aumentaram em muitos casos, mesmo naqueles com aumento de rendimento, o que indica que pode-se obter rendimentos melhores ainda buscando-se uma queima mais eficiente desses hidrocarbonetos não queimados. Quando a emissão de CO é baixa em conjunto com alta emissão de THC não há melhorias, pois o baixo índice de CO é resultado de condições pouco propícias para a oxidação de todo o combustível.

Pode-se supor que há extinção de chama em algumas regiões da câmara de combustão. De acordo com essa hipótese a chama queima o combustível com bom aproveitamento (baixo índice de $\mathrm{CO}$ ) por onde passa, e os THC vêm dos locais não alcançados por ela. O regime $\operatorname{com} \lambda=2,00$ apresenta uma tendência natural de aumento na concentração de THC com misturas muito pobres e falhas na combustão, da mesma forma que algumas séries de regimes com a mesma rotação apresentam aumento nessa emissão a partir de determinado ponto de excesso de ar onde ela é mínima.

\subsubsection{Regimes de máxima potência}

Como a ECU original é programada para enriquecer a mistura ar-combustível a partir de deteriminada abertura da borboleta de aceleração para fornecer máxima potência, também foram realizados ensaios com mistura estequiométrica/combustível líquido e com mistura rica/combustível vaporizado. Dessa forma pode-se fazer uma comparação mais justa entre tais regimes, tendo-se quatro combinações; evitando comparações injustas entre regimes com razões ar-combustível muito distantes, que levam a grandes disparidades em rendimento e emissões específicas.

A tabela 4.6 confronta esses dados para o regime de 2000rpm. Mesmo não sendo possível estabilizar o funcionamento do motor com combustível vaporizado na mesma relação ar-combustível programada na ECU original $(\lambda=0,92)$, nota-se que a diminuição do torque fornecido é pequena frente à economia proporcionada quando o motor opera com mistura estequiométrica e combustível vaporizado. Também ocorreram drásticas reduções nas emissões específicas de CO e THC. O aumento nas emissões de $\mathrm{NO}_{x}$ é esperado devido à falta do efeito refrigerante causado pela admissão de etanol líqiudo no cilindro, tanto com combuustível vaporizado quanto com combustível líquido em menor quantidade. O consumo de ar também diminui de 13,49g/s (en- 
saios de D’Ávila [23]) para 12,75 g/s quando se passa a usar combustível vaporizado, devido ao espaço ocupado por ele nos dutos de admissão.

A mesma comparação foi realizada a $3000 \mathrm{rpm}$ e está na tabela 4.7. Também foi observada ligeira diminuição no consumo de ar devido ao espaço ocupado pelo vapor de etanol. Nesse regime porém foi possível diminuir apenas as emissões específicas de CO comparando regimes estequiométricos, enquanto nos regimes ricos o etanol vaporizado tem apenas as emissões específicas de $\mathrm{NO}_{x}$ elevadas.

Como a válvula borboleta já está totalmente aberta nota-se que não há aumento de eficiência quando se empobrece a relação ar-combustível, ao menos nos valores estudados. Os regimes pobres com etanol vaporizado entretanto apresentaram menores índices de emissões.

O último regime a ser avaliado, 4000rpm e WOT, não pôde ter um equivalente com etanol vaporizado. Um dos fatores foi a limitada capacidade de fornecimento de vapor pela caldeira, que não se deve a falta de área de troca de calor mas sim a perdas de carga entre a saída do vapor e seu transporte até a válvula gaveta que dosa a vazão de combustível gasoso. Durante eses regimes de consumo de vapor da ordem de $3,0 \mathrm{~g} / \mathrm{s}$, a pressão no trocador não caiu, o que indicaria deficiência na capacidade de continiar produzindo vapor à taxa requisitada. Isso é um indicador da influência da perda de carga na saída de vapor que não foi estimada na fase de projeto do equipamento.

Dessa forma não se conseguiu operar o motor com menos de $50 \%$ de excesso de ar na condição de 4000rpm/WOT. Esse regime não possui uma faixa de avanço de ignição que permita operálo sem detonação porém com torque. Quando atrasava-se o ângulo de ignição para evitar detonação tinha-se uma espécie de marcha-lenta a 4000rpm, onde o motor não foi capaz de fornecer torque algum.

Tentou-se estabilizar a temperatura da água na entrada da caldeira em valores maiores que os $96^{\circ} \mathrm{C}$ previstos incialmente, para obter maiores pressões que permitissem fornecer maior vazão de combustível com as perdas de carga existentes. Até os $98^{\circ} \mathrm{C}$ isso pôde ser feito com relativa tranquilidade, acima desse valor a temperatura da água ficou instável e passou a oscilar de forma irregular, ultrapassando os $100^{\circ} \mathrm{C}$, limite estabelecido para funcionar o motor com segurança.

\subsection{Aquecimento transiente}

Um parâmetro importante num MAPV é o tempo necessário para aquecer os componentes do sistema de vaporização de combustível de forma a minimizar o intervalo necessário para que a comutação líquido-vapor seja feita. Foram avaliados o tempo de aquecimento da água do sistema de arrefecimento com e sem a válvula temostática instalada. Essa válvula fica fechada 
nos primeiros minutos de funcionamento do motor, impedindo que a água circule por todo o sistema, ficando restrita ao bloco do motor. Ao atingir determinada temperatura ela se abre permitindo que essa água circule pelo radiador e, no caso, pela caldeira produtora de vapor.

Foram realizados dois ensaios de aquecimento, pela manhã, em dias consecutivos, para começar com todo o motor a temperatura ambiente. O primeiro ensaio foi feito com a válvula termostática instalada, e o outro com esse componente retirado. Em ambos os casos a pressão na caideira foi monitorada, encerrando-se o ensaio quando atingia-se $0,5 \mathrm{kgf} / \mathrm{cm}^{2}$, pressão considerada satisfatória para o fornecimento de vapor para o motor. O sistema de aquisição de temperaturas foi configurado para registrar as temperaturas da água do sistema de arrefecimento e na saída da caldeira, bem como a do óleo lubrificante, a cada 5 segundos.

Em ambos os ensaios o aquecimento foi realizado com o motor sob carga. A válvula que liga a caldeira à válvula gaveta ficou aberta desde o início, de forma a permitir a passagem de vapor em pequenas quantidades à medida em que a caldeira se aquecia. A ECU programável permita uma modalidade de ajuste rápido do mapa de ignição que aumenta ou diminui todos os seus pontos com um único comando, o que permite alterar a quantidade de combustível líquido injemaneiraforma a injeção de combustível líquido pòde dar espaço à admissão de combustível gasoso de forma gradual. Quando o display da ECU programável mostrava "Ajuste rápido: Todo mapa -99\%"sabia-se que o motor estava operando quase que exclusivamente com combustível vaporizado, bastando comutar a chave do kit GNV para que se pudesse controlar a vazão de combustível através da válvula gaveta. Nos dois casos torque fornecido variou de forma irregular, porém com tendência crescente, à medida que o motor se aquecia.

A figura 4.19, refrente ao aquecimento com válvula termostática, mostra a evolução das referidas temperaturas ao longo do tempo. O motor foi operado nas seguintes condições: $\omega=3000 \mathrm{rpm}$, $\mathrm{TBS}=22,0^{\circ} \mathrm{C}, \mathrm{TBU}=19,0^{\circ} \mathrm{C}, \mathrm{p}_{a b s}=695,8 \mathrm{mmHg}, \dot{m}_{a r}=8,69 \mathrm{~g} / \mathrm{s},|\phi|=16,00 \%$. Aos $250 \mathrm{~s}$ de funcionamento foi colocada a carga através do dinamômetro, aos 780s a pressão na caldeira começou a ficar acima da atmosférica, aos 825 s foi necessário abrir a borboleta para $|\phi|=36,75 \%$ para um controle rápido da razão ar-combustível, aos $885 \mathrm{~s}$ a ventoinha foi ligada e aos $905 \mathrm{~s}$ foi realizada a comutação para gás no kit GNV.

Nota-se que a temperatura da água na entrada da caldeira continua igual à ambiente até os $285 \mathrm{~s}$, quando começa a subir vertiginosamente até uma tendência de estabilização aos 550s quando volta a subir. A temperatura da água na saída da caldeira tem uma diferença considerável em relação à de entrada até 750s, o que indica que indica que nesse período o combustível está recebendo calor sensível até atingir uma temperatura própria à vaporização. A evolução das temperaturas da água e do óleo lubrificante para aquecimento sem a presença da válvula termostática está ilustrada na figura 4.20. As condições de funcionamento foram: $\omega=3000 \mathrm{rpm}$, 
Tabela 4.6: Medidas de desempenho a 2000rpm e WOT com diversas combinações de razão ar-combustível e alimentação.

\begin{tabular}{|c|c|c|c|c|}
\hline & $\begin{array}{c}\text { Líquido rico } \\
(\lambda=0,92)\end{array}$ & $\begin{array}{c}\text { Líquido } \\
\text { estequiométrico }\end{array}$ & $\begin{array}{c}\text { Vapor rico } \\
(\lambda=0,86)\end{array}$ & $\begin{array}{c}\text { Vapor } \\
\text { estequiométrico }\end{array}$ \\
\hline$\tau$ & 58,6 & 55,6 & 55,6 & 57,9 \\
\hline$\eta(\%)$ & 27,9 & 30,9 & 24,6 & 30,9 \\
\hline$\dot{m}_{\text {etanol }}$ & 1,77 & 1,51 & 1,90 & 1,57 \\
\hline$\dot{m}_{a r}$ & 13,49 & 13,45 & 12,79 & 12,75 \\
\hline $\mathrm{CO}(\mathrm{g} / \mathrm{kWh})$ & 104,02 & 5,69 & 220,11 & 14,32 \\
\hline $\mathrm{THC}(\mathrm{g} / \mathrm{kWh})$ & 2,76 & 4,05 & $0,23^{\S}$ & 0,77 \\
\hline $\mathrm{NO}_{x}(\mathrm{~g} / \mathrm{kWh})$ & 3,56 & 7,58 & 6,85 & 6,71 \\
\hline
\end{tabular}

$\S$ Valor acusado pelo instrumento de medida fora do esperado, porém mantido.

Tabela 4.7: Medidas de desempenho a 3000rpm e WOT com diversas combinações de razão ar-combustível e alimentação.

\begin{tabular}{|c|c|c|c|c|c|c|}
\hline & Líquido rico & Líquido & Vapor rico & Vapor & \multicolumn{2}{|c|}{ Vapor pobre } \\
\cline { 6 - 8 } & $(\lambda=0,91)$ & esteq. & $(\lambda=0,95)$ & esteq. & $\lambda=1,2$ & $\lambda=1,4$ \\
\hline$\tau$ & 64,4 & 65,46 & 62,05 & 60,98 & 49,68 & 39,63 \\
\hline$\eta(\%)$ & 28,2 & 32,3 & 31,07 & 33,1 & 30,3 & 27,8 \\
\hline$\dot{m}_{\text {etanol }}$ & 2,87 & 2,56 & 2,47 & 2,33 & 2,07 & 1,80 \\
\hline$\dot{m}_{\text {ar }}$ & 21,76 & 21,53 & 20,71 & 20,8 & 21,45 & 20,89 \\
\hline $\mathrm{CO}(\mathrm{g} / \mathrm{kWh})$ & 109,6 & 18,31 & 66,75 & 6,95 & 3,85 & 4,25 \\
\hline $\mathrm{THC}(\mathrm{g} / \mathrm{kWh})$ & 2,12 & 0,35 & 0,74 & 0,66 & 0,56 & 0,93 \\
\hline $\mathrm{NO}_{x}(\mathrm{~g} / \mathrm{kWh})$ & 2,65 & 6,70 & 6,84 & 7,15 & 0,36 & 0,15 \\
\hline
\end{tabular}

$\mathrm{TBS}=25,0^{\circ} \mathrm{C}, \mathrm{TBU}=22,5^{\circ} \mathrm{C}, \dot{m}_{a r}=8,50 \mathrm{~g} / \mathrm{s},|\phi|=16,00 \%$. A carga foi imposta ao motor antes dos 60 s de funcionamento e o torque fornecido cresceu monotoincamente de $6,6 \mathrm{Nm}$ até $12,5 \mathrm{Nm}$ quando fez-se a comutação para alimentaçao gasosa. Aos 707s de funcionamento a ventoinha foi ligada e a alimentação foi comutada aos 720s. Percebe-se que as temperaturas da água evoluem de forma praticamente linear, mantendo a diferença entre entrada e saída praticamente constantes.

Aos 580s a pressão de vapor na caldeira começa a subir e já está em $0,55 \mathrm{kgf} / \mathrm{cm}^{2}$ aos $695 \mathrm{~s}$, tempos menores que aqueles observados para o aquecimento com válvula termostática.

Em ambos os casos a temperatura do óleo lubrificante aumenta de forma semelhante, estabilizando-se na casa dos $85^{\circ} \mathrm{C}$. Após alguns minutos de funcionamento com a água aquecida ela volta a se elevar até ficar na casa dos $110^{\circ} \mathrm{C}$, atingindo picos de $120^{\circ} \mathrm{C}$. A evolução da pressão na caldeira dos ensaios de aquecimento transiente está ilustrada na figura 4.21. Nota-se que sem válvula termostática (linha clara) a pressão atinge um nível satisfatório em menos de 700s, enquanto o aquecimento com válvula termostática demora 780s para começar o aumento de 


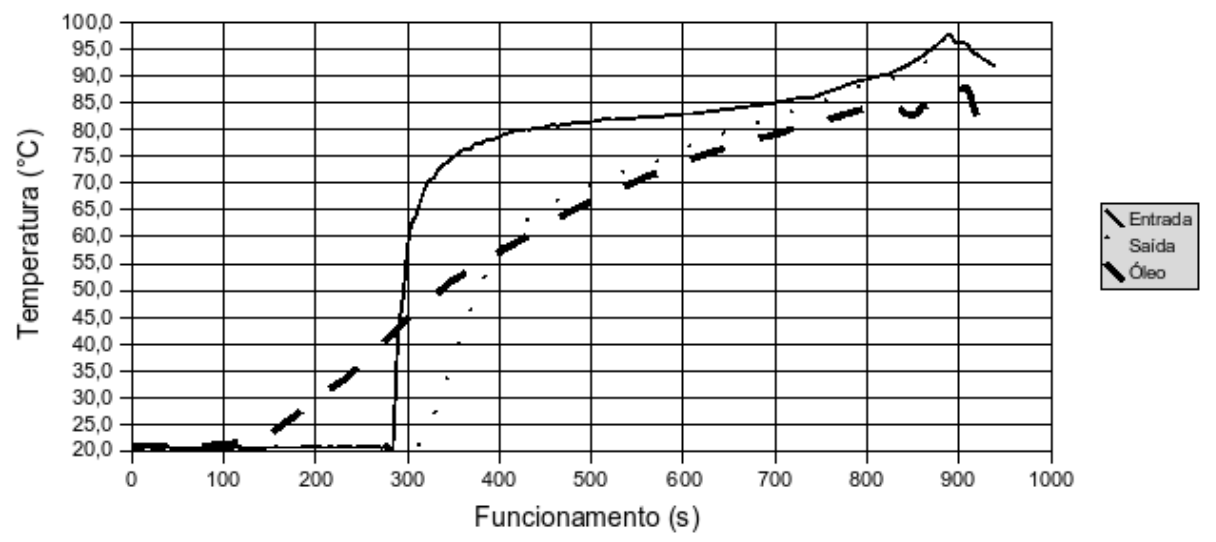

Figura 4.19: Aquecimento da água e do óleo lubrificante, com a válvula termostática instalada.

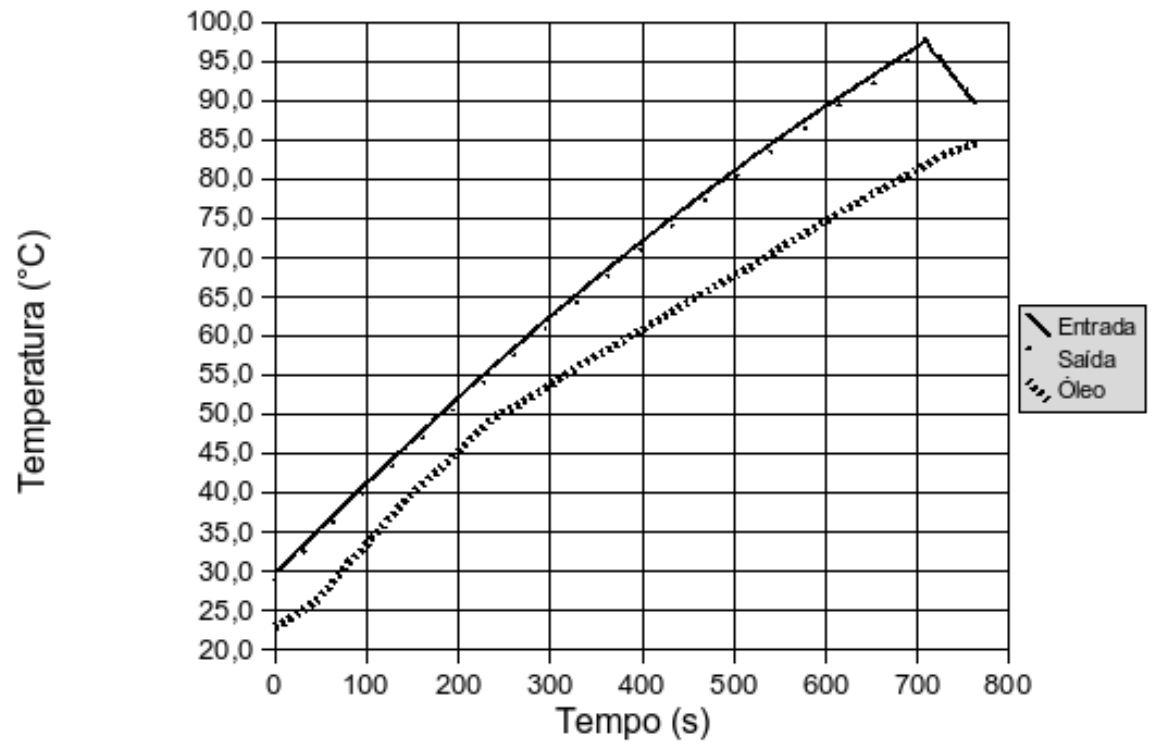

Figura 4.20: Aquecimento da água e do óleo lubrificante, sem a válvula termostática instalada. 


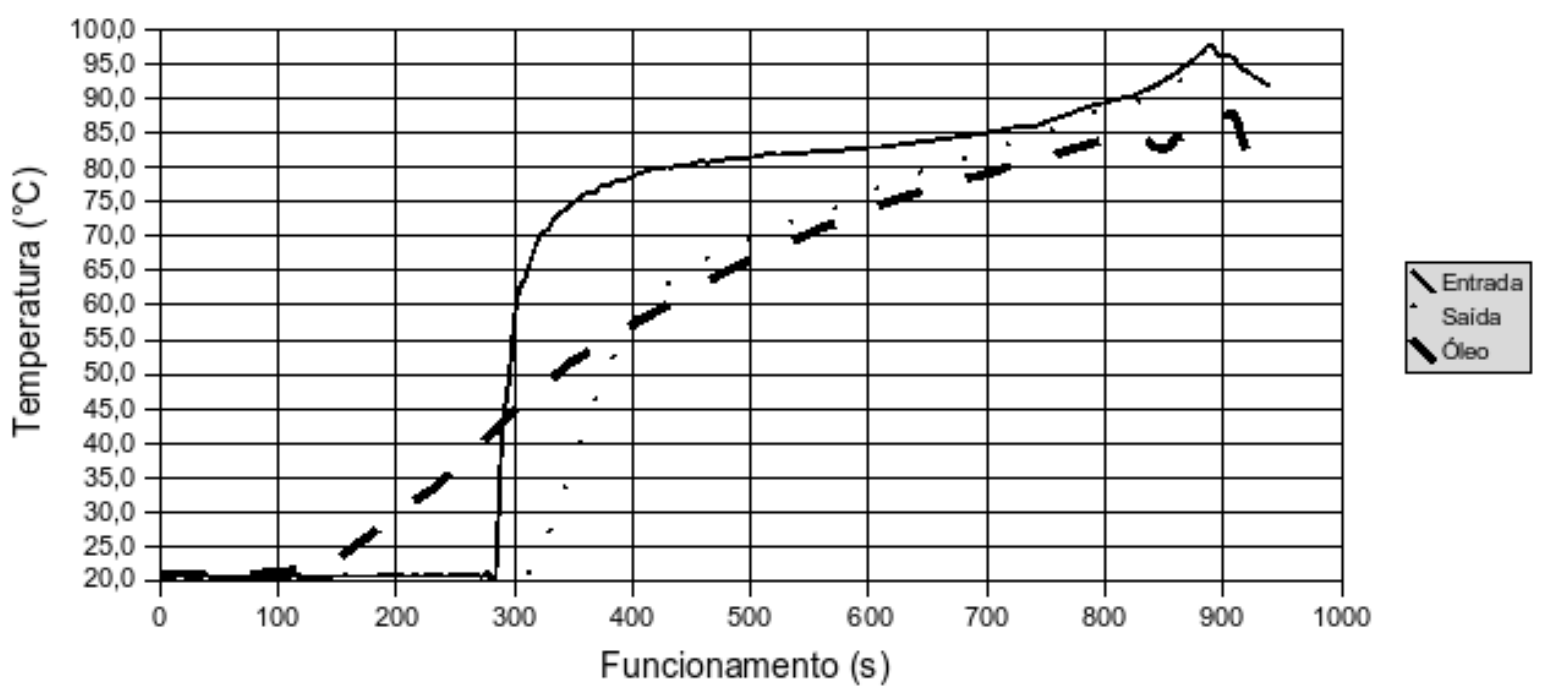

Figura 4.21: Evolução da pressão do etanol na caldeira, com e sem válvula termostática.

pressão e aproximadamente 920s para produzir vapor à pressão necessária. 


\section{Capítulo 5}

\section{Conclusões}

Na maioria dos regimes estudados o MAPV mostrou potencial para melhoria na eficiência, ou seja, produzir em determinada velocidade angular o mesmo torque com menor consumo de combustível. Em regimes permanentes foram encontrados pontos de melhor eficiência e/ou níveis de emissões mais satisfatórios que aqueles realizados como o módulo de injeção eletrônica original, restando desenvolver maneiras de operá-lo em regimes transientes com estabilidade e desempenho. Por enquanto o sucesso em regimes permanentes permite usá-lo em aplicações estacionárias (onde não houver disponibilidade de gás natural, que no atacado é uma commodity mais barata por unidade de energia fornecida) ou mesmo em veículos híbridos (que têm um motor elétrico e outro a combustão interna) que operem com seu motor a combustão sempre próximo ao regime de máxima eficiência.

Um veículo com MAPV preparado para condições reais de uso pode ser submetido aos testespadrão de emissões para verificar se atende às exigências legais de emissões. Os testes em bancada não são suficientes para essa questão. Caso seja possível reduzir apenas uma categoria de poluente, como combustível parcialmente queimado ou óxidos de nitrogênio, ou ainda reduzir todas elas; pode-se propor um conversor catalítico que não seja de três vias e realize apenas a tarefa de oxidar ou reduzir, ou desenvolver um conversor catalítico de três vias que cause menores perdas de carga, contribuindo para mehorias no rendimento do motor.

O torque pretendido foi conseguido nos regimes com alimentação de combustível vaporizado com maiores aberturas da borboleta de aceleração na maioria dos casos, o que não prejudicou o torque em máxima aceleração. Portanto, regimes intermediários que vão até o torque máximo para cada rotação podem ser realizados com ajustes na injeção de combustível, que podem levar a regimes com pouco excesso de ar para restabelecer o torque original.

O sistema usado para alimentação, de injeção indireta monoponto, não é favorável à operação com grandes taxas de admissão de ar nem com valores altos de excesso do mesmo. O vapor de combustível, por ter densidade muito menor que a do combustível líquido, ocupa espaço que deveria ser do ar de admissão, impedindo que parte dele adentre os cilindros. da mesma forma 
a mistura homogênea formada e pré-misturada ao longo dos dutos de admissão, com excesso de ar, é um convite a irregularidades na chama. Há a vantagem colateral de atingir-se menores temperaturas de chama e menores emissões de óxidos de nitrogênio com esse tipo de mistura inflamável, desde que o efeito da diluição do combustível compense a falta do efeito refrigerante devido à reitrada de calor latente para a evaporação do combustível líquido.

Os avanços de ignição (e conseqüentemente os tempos de combustão) que fornecerem valores aceitáveis de rendimento e emissões não foram menores com etanol vaporizado na maioria dos regimes estudados. Dessa forma presume-se que a combustão foi mais lenta nesses regimes, o que é de se esperar em misturas mais diluídas.

Chegou-se a operar o MAPV com $100 \%$ de excesso de ar $(\lambda=2,00)$, porém com valores desfavoráveis de eficiência e emissões de CO e THC. Não se pode ainda operar esse motor com a borboleta aberta em todos os regimes, como se fosse um motor ciclo Diesel. O que se pode fazer é trabalhar com aberturas da borboleta de aceleração maiores que aquelas que forneceriam a mesma combinação torque-rotação em alguns regimes. Não se sabe ainda como proceder em regimes com aberturas menores que $24 \%$ e em regimes de marcha-lenta. 


\section{Capítulo 6}

\section{Sugestões para trabalhos futuros}

Para melhorar a viabilidade técnica e econômica do MAPV, pode-se trabalhar as seguintes alternativas:

- Estudar evaporação do etanol com a variação de diversos parâmetros como: superfícies, materiais, superaquecimento de parede, e geometria do trocador de calor [44]. Tais estudos permitirão a construção de geradores de vapor mais compactos e seguros (por transportar menores quantidades de combustível a alta temperatura), que poderão atender a motores nas mais diversas faixas de potência.

- Considerar a influência das vibrações causadas pelo motor sobre a ebulição do combustível, com o mesmo objetivo do item anterior.

- Desenvolver algoritmo para controlar abertura da borboleta de acordo com o torque pretendido de forma conveniente (drive by wire).

- Usar dispositivos como Supercharger para melhorar o rendimento volumétrico, sempre prejudicado com injeção indireta de combustível gasoso.

- Operar um evaporador com o calor disponível no óleo lubrificante, que trabalha em temperaturas maiores (entre $120^{\circ} \mathrm{C}$ e $140^{\circ} \mathrm{C}$ ), ou temperatura mais elevada da água de arrefecimento, para produzir etanol vaporizado a presssões maiores. Pressões absolutas mais elevadas, entre $200 \mathrm{kPa}$ e $300 \mathrm{kPa}$ (figura 3.2) poderiam ser atingidas, permitindo o uso de bicos injetores projetados para combustíveis gasosos como GNV, GLP ou hidrogênio, eliminando a necessidade de dispositivo de sucção utilizado neste trabalho e trazendo a possibilidade de injeção direta e carga estratificada.

- Elevar a temperatura de trabalho da a água do arrefecimento com o uso de aditivos, o que também permitiria a geração de vapor a pressão apropriada para o uso de bicos injetores de gás. 
- Usar reguladores de pressão para fornecer combustível a pressão constante, ao invés de controlar a temperatura da água. Dessa forma a diferença de pressão através da válvula com motor de passo ou dos bicos injetores não está sujeita à temperatura do óleo ou da água do arrefecimento. Válvulas usadas para gás natural ou GLP podem ser utilizadas desde que as devidas regulagens e adaptações sejam feitas. Para operar com etanol vaporizado essas válvulas precisam ter eventuais partes em alumínio substituídas por latão, usar membranas de aço inoxidável ou de borrachas nitrílicas, além de receber nova calibração para as faixas de pressão em que vão funcionar. Deve-se tomar cuidado com a menor vazão másssica nominal com etanol vaporizado, causada pela maior viscosidade desse combustível.

- Buscar maneiras seguras e energeticamente viáveis para reduzir o tempo de aquecimento do combustível, para que um veículo possa usá-lo na forma vaporizada durante mais tempo.

- Estudar o uso de etanol vaporizado em motores com pistões rotativos (Wankel). Desvantagens que esses motores têm devido ao formato de suas câmaras de combustão podem ser sublimadas com o uso de combustível na forma gasosa, como a condensação do mesmo nas paredes e frestas da câmara de combustão ou ainda problemas na velocidade de propagação da chama. Burley [55] apud Dulger [56] já conseguiu diminuir as emissões de HC num motor Wankel usando metano como combustível.

- Analisar a durabilidade do óleo lubrificante num MAPV. Sabe-se que o etanol - e principalmente o etanol vaporizado - diminuem a deterioração do lubrificante, pela sua menor afinidade química e menor disposição a formar depósitos nas câmaras de combustão. Falta, porém, resultados quantitativos.

- Desenvolver formatos de câmara de combustão otimizados para queima de etanol vaporizado.

- Estudar o uso de conversores catalíticos adequados à realidade do MAPV. Etapas futuras de seu desenvolvimento podem levar a emissões menores porém ainda superiores às regulamentadas, que poderiam ser convertidas com catalisadores que causam menor perda de carga se houver um nível seguro que essas emissões não atinjam. Pode-se ainda chegar a um ponto em que se diminua apenas óxidos de nitrogênio ou apenas combustíveis parcialmente queimados, tornando desnecessário um dos catalisadores (redução ou oxidação) no caso do modelo de três vias. 
- Usar 2,5-dimetilfurano na alimentação de um MCI para avaliar a possibilidade de usar esse combustível na forma vaporizada. Devido às suas diferenças em relação ao etanol, deve-se buscar novos parâmetros para viabilizar seu uso em motores de combustão interna e num gerador de vapor. Valores ótimos de taxa de compressão, razão ar-combustível e momento de ignição devem ser buscados, bem como os níveis de temperatura e emissões de poluentes que se pode atingir.

- Realizar testes dinâmicos de dirigibilidade, em autódromos ou nas ruas, com o MAPV instalado num veículo ao invés de estar no dinamômetro de bancada.

- O desenvolvimento de trocadores de calor mais compactos e o uso do óleo lubrificante como fonte de calor podem ajudar no desenvolvimento de MAPVs adequados à realidade das motocicletas, visando reduzir a poluição atualmente causda por elas. 


\section{Referências Bibliográficas}

[1] MAGALHÃES, M. Missões estrangeiras para o Álcool. In: Jornal Cana. 137. ed. Ribeirão Preto-SP: Procana Informações e Eventos, 2005. p. 16-17.

[2] ASSOCIAÇÃO NACIONAL DOS FABRICANTES DE VEÍCULOS AUTOMOTORES. Anuário Estatístico da Indústria Automotiva Brasileira. São Paulo-SP, 2003.

[3] NASCIMENTO, D.; PINTO, R. Logística para exportar Álcool. In: Revista Idea News. 54. ed. Ribeirão Preto-SP: Idea News Comunicações, 2005. p. 8-14.

[4] INTERGOVERNAMENTAL PANEL ON CLIMATE CHANGE. Climate Change 2007: The physical science basis. Geneva, (Suíça), 2007. Summary for Policymakers. Disponível em: <http://www.ipcc.ch/SPM2feb07.pdf>. Acesso em: 05 mar. 2007.

[5] MELlo Jr., A. G. Petróleo... até quando? 200-. Disponível em: $<$ http://meusite.mackenzie.com.br/mellojr/Petroleo/petroleo.htm>. Acesso em: 31 ago. 2005.

[6] CARVALHO, L. C. C. Etanol: Impactos econômicos no brasil. São Paulo-SP: Única, 1999.

[7] ROMÁN-LESHKOV, Y. et al. Production of dimethylfuran for liquid fuels from biomassderived carbohydrates. Nature, v. 447, n. 7147, p. 982-986, 2007.

[8] INSTITUTO DO MEIO AMBIENTE E DOS RECURSOS NATURAIS RENOVÁVEIS. Programa para controle de emissões veiculares. Brasília-DF, 2005. Disponível em: $<$ www.ibama.gov.br>. Acesso em: 7 set. 2005.

[9] ASSOCIAÇÃO BRASILEIRA DOS FABRICANTES DE MOTOCOCLETAS CICLOMOTORES MOTONETAS BICICLETAS E SIMILARES. Motociclos: Produção 2004. São Paulo-SP, 2005. Disponível em: < http://www.abraciclo.com.br/prod04.html>. Acesso em: 7 set. 2005.

[10] CONSELHO NACIONAL DE MEIO AMBIENTE. Resolução 297, de 26 de fevereiro de 2002. Brasília-DF, 2002. Disponível em: 
<http://www.ibama.gov.br/proconve/ArquivosUpload/5resolucao_297-02_-_promot.pdf>. Acesso em: 30 ago. 2005.

[11] CONSELHO NACIONAL DE MEIO AMBIENTE. Resolução 342 de 25 de fevereiro de 2003. Brasília-DF, 2003. Disponível em: $<$ http://www.ibama.gov.br/proconve/ArquivosUpload/0resolucao_342-03_-_promotcomplementar.pdf >. Acesso em: 30 ago. 2005.

[12] BRANDT Y. WANG, J. W. G. E. P. Dynaminc modeling of a three-way catalyst for sparkignition engine exhaust emission control. IEEE Transactions on Control Systems Technology, v. 8 , n. 5 , p. 767-776, 2000.

[13] MARTINS, K. C. R. Estudo da aplicação de conversores catalíticos platina paládio com auxiliar no processo de controle das emissões automotivas. Dissertação (Mestrado) — Escola de Engenharia de São Carlos-USP, São Carlos-SP, 2003.

[14] NATIONAL SCIENCE AND TECHNOLOGY COUNCIL. Interagency assesment on oxygenated fuels. Washington-DC, 1997. Disponível em: $<$ http://www.epa.gov/otaq/regs/fuels/ostpexec.pdf>. Acesso em: 31 ago. 2005.

[15] ESTADOS UNIDOS DA AMÉRICA. Clean Air Act. Washington-DC, 1990. Disponível em: <http://www.epa.gov/oar/caa/caa.txt>. Acesso em: 10 set. 2005.

[16] POULOPOULOS, S. G. et al. Regulated and unregulated emissions from an internal combustion engine operating on ethanol-containing fuels. Atmospheric Environment, n. 35, p. 4399-4406, 2001.

[17] PAU, F. S. Análise experimental dos fenômenos e da emissão de gases em motores de combustão interna utilizando misturas de etanol e gasolina como combustível. Tese (Doutorado) — Escola de Engenharia de São Carlos-USP, São Carlos-SP, 2003.

[18] HOCHGREB, S. Combustion-related emissions in spark-ignited engines. In: .Handbook of air pollution from internal combustion engines. San Diego-CA: Academic Press, 1998. p. 119-164.

[19] CELERE, S. W. Desempenho de motores de ignição por centelha com álcool etílico préevaporado. Tese (Doutorado) — Escola de Engenharia de São Carlos-USP, São Carlos-SP, 1981.

[20] VENANZI, D. Contribuição técnica ao emprego de álcool etílico em motores de ciclo Otto. Tese (Doutorado) - Escola de Engenharia de São Carlos-USP, São Carlos-SP, 1972. 
[21] BERGMAN, H. H. A highly efficient alcohol vapor aspirating spark-ignition engine with heat recovery. SAE paper 821190, p. 77-88, 1982.

[22] D’AVILA, M. T. Estudo de um motor de combustão interna, do ciclo Otto, movido a etanol pré-vaporizado. Dissertação (Mestrado) — Escola de Engenharia de São Carlos-USP, São Carlos-SP, 1994.

[23] D'AVILA, M. T. Estudo de um motor regenerativo, do ciclo Otto, movido a etanol prévaporizado. Tese (Doutorado) — Escola de Engenharia de São Carlos-USP, São Carlos-SP, 2003.

[24] SHER, E. (Org.). Handbook of air pollution from internal combustion engines: Pollutant formation control. San Diego-CA: Academic Press, 1998.

[25] WARNATZ, J. Combustion: physical and chemical fundmentals, modeling and simulation, experiments, pollutant formation. 3. ed. New York: Springer, 2001.

[26] HARRINGTON, J. A.; SHISHU, R. C. A single-cylinder engine study of the effects of fuel type, fuel stoichiometry and hydrogen-to-carbon ratio on $\mathrm{CO}, \mathrm{NO}$ and $\mathrm{HC}$ exhaust emissions. SAE paper 730476, 1973.

[27] FERGUSON, C. R. Internal Combustion Engines: applied thermosciences. New York: John Wiley \& sons, 1986.

[28] HOHSHO, Y. et al. Characteristics of response of carbureted spark ignition engines under transient conditions. Bulletin of Japanese Society of Mechanical Engineeers, n. 242, p. 1725$1732,1985$.

[29] COOPER, C. D.; ALlEY, F. C. Air Pollution Control. New York: Waveland Press Inc., 1994.

[30] da SILVA, J. A. Estudo dos processos de admissão e exaustão utilizando ensaio experimental e simulação de um motor de combustão interna a etanol aspirado e turboalimentado. Tese (Doutorado) — Escola de Engenharia de São Carlos-USP, São Carlos-SP, 2004.

[31] SONHO Possível. In: REVISTA Duas Rodas. 318. ed. Rio de Janeiro-RJ: Sisal, 2003. p. $46-48$.

[32] SOUZA, S. G. Um estudo sobre a evolução das câmaras se combustão dos motores do ciclo Otto a gasolina e sua aplicação ao etanol hidratado como combustível alternativo. Dissertação (Mestrado) — Escola de Engenharia de S. Carlos-USP, São Carlos-SP, 2004. 
[33] FEITOSA, M. V. Estudo da partida a frio em motores movidos a etanol. Tese (Mestrado) — Escola de Engenharia de S. Carlos-USP, São Carlos-SP, 1998.

[34] SATO, T. et al. Countermeasures against the icing problem on the ATREX precooler. Acta Astronautica, n. 54, p. 671-686, 2004.

[35] GUTHEIL, E. Numerical analysis of the autoignition of methanol, ethanol, n-heptane and n-octane sprays with detailed chemistry. Combustion Science and Technology, v. 105, p. $265-278,1985$.

[36] WIKIPEDIA, THE FREE ENCYCLOPEDIA. Methane. [S.1.], 2006. Disponível em: $<$ http://en.wikipedia.org/wiki/Methane>. Acesso em: 04 dez. 2006.

[37] TAYLOR, C. F. Análise dos Motores de Combustão Interna. 2. ed. São Paulo-SP: Edgard Blücher Ltda., 1988. Tradução de Mauro Omeu Cardoso Amorelli.

[38] PETRÓLEO BRASILEIRO S/A. Dúvidas: Gasolina comum. Rio de Janeiro-RJ, 2005. Disponível em: <www.br.com.br/portalbr/calandra.nsf>. Acesso em: 19 set. 2005.

[39] STRAHLE, W. C. An Introduction to Combustion. Longhorn-PA: Gordon and Breach Science Publishers, 1993.

[40] KANURY, A. M. Introduction to combustion phenomena: For fire, incineration pollution and energy applications. Yverdom (Suíça): Gordon and Breach Science, 1992.

[41] KAZAKOV, A. et al. Detailed modeling of an isolated, ethanol droplet combustion under microgravity conditions. Combustion and Flame, n. 134, p. 301-314, 2003.

[42] INCROPERA, F. P.; DEWITT, D. P. Fundamentos da Transferência de Calor e de Massa. 4. ed. Rio de Janeiro-RJ: Livros Técnicos e Científicos Editora, 1998.

[43] KREITH, F. Princípios da Transmissão de Calor. São Paulo-SP: Edgard Blücher Ltda., 1973.

[44] THOME, J. R. Enhanced Boiling Heat Transfer. New York: Hemisphere Publishing Corp., 1990.

[45] NUKIYAMA, S. The maximum and minimum values of heat transmitted from metal to boiling water under atmospheric pressure. Journal of Japanese Society of Mechanical Engineering, n. 37, p. 367, 1934. 
[46] VOLKSWAGEN DO BRASIL LTDA. Gol Special: Manual de operações. 11. ed. São Bernardo do Campo-SP: [s.n.], 2002.

[47] LEE, Y. H.; KIM, D. H.; S, H. C. An experimental investigation on the experimental critical heat flux enhancement by mechanical vibration in vertical round tube. Nuclear Engineering and Design, n. 229, p. 47-58, 2004.

[48] PORTO, R. M. Hidráulica Básica. 3. ed. São Carlos-SP: EESC, 2004.

[49] CONSELHO NACIONAL DE MEIO AMBIENTE. Resolução 315 de 29 de outubro de 2002. Brasília-DF, 2002. Disponível em: $<$ http://www.ibama.gov.br/proconve/ArquivosUpload/6resolucao_315-02__novas_etapas.pdf $>$. Acesso em: 8 set. 2005.

[50] ROSE, J. W.; COOPER, J. R. Techinical Data on Fuel. 7. ed. Londres, 1977. Revisado para unidades SI.

[51] HEWITT, G. F. Heat Exchanger Design Handbook: Physical properties. Washington-DC: Hemisphere Publishing Corporation, 1983.

[52] CHEMICAL RUBBER COMPANY. CRC Handbook of Chemistry and Physics: A readyreference book of chemical and physical data. Boca Raton-FL: CRC Press Inc., 1985.

[53] ANDERSON Jr., J. Modern compressible flow with historical perspective. 3. ed. Singapore: McGraw Hill, 2003.

[54] REID, R. C.; SMITH, J. M. Thermodynamic properties of etyhl alcohol. Chemical Engineering Processes, v. 47, n. 8, 1951.

[55] BURLEY, R. J.; MELOENEY, M. R.; STARK, T. L. Source of hydrocarbon emissions on rotary engines. SAE paper 780419, 1978.

[56] DULGER, M. Pollution from rotary internal combustion engines. In: Handbook of air pollution from internal combustion engines. San Diego-CA: Academic Press, 1998. p. 171-188. 


\section{Apêndice A}

\section{Glossário}

APMS: Antes do Ponto Morto Superior.

Superaquecimento de parede: Diferença de temperatura entre a superfície transmissora de calor a um fluido em ebulição e a temperatura de saturação do mesmo.

Golpe de ariete: Choque de líquido que indesejado em tubulações destinadas tanto a líquidos como a gases. Pode danificar seriamente seus componentes.

Título de vapor: Em uma substância que passa por evaporação (ou condensação) a pressão constante, é a razão entre a massa que está na forma gasosa e a massa total.

Vapor flash: Vapor formado instantaneamente quando um líquido saturado expande-se. À mesma entalpia específica corresponde um título maior para uma pressão menor que aquela anterior à expansão.

Mistura estequiométrica: Mistura (no caso entre ar e combustível) na porporção teoricamente correta para que não sobre reagentes após o término da reação. Na prática sobra um pouco de reagentes e produtos mesmo nessa condição.

Mistura rica: Mistura que contém razão ar/combustível menor (ou maior relação combustível/ar) que a definida na condição estequiométrica.

Mistura pobre: $\mathrm{O}$ oposto de mistura rica.

Desnaturante: Substância adicionada ao etanol carburante para tornar seu odor e sabor desagradáveis, para evitar que seja usado como bebida.

Centralina: Módulo de injeção eletrônica.

MAP: Manifold Air Pressure, ou pressão no coletor de admissão. 
PMS: Ponto Morto Superior, o nível mais elevado que o pistão atinge em seu movimento alternativo.

TPS: Throttle Position Sensor, ou sensor de posição da borboleta de aceleração.

WOT: Wide Open Throttle, ou abertura total da borboleta de aceleração.

Poder Calorífico Inferior: Energia fornecida pela queima do combustível considerando que o vapor d'água formado não se condensa.

Poder Calorífico Superior: Energia fornecida pela queima do combustível quando atinge-se condições propícias para a condensação do vapor d'água formado. A diferença entre os poderes caloríficos superior e inferior é o calor latente de condensação da água formada. 


\section{Apêndice B}

\section{Fórmulas utilizadas}

\section{B.1 Polinômio interpolador}

A pressão de vapor de etanol e a densidade do vapor saturado em função da temperatura foram calculadas sempre que necessário com ajuda de um polinômio interpolador de Lagrange para argumentos igualmente espaçados. A tabela B.1 traz valores de pressão absoluta de vapor na saturação e densidade de vapor saturado, na faixa de temperaturas de $-3^{\circ} \mathrm{C}$ até $127^{\circ} \mathrm{C}$ (270K a 400K), com intervalos de 10K. A igualdade de espaçamento dos argumentos (no caso a temperatura) permite uma mudança de variável na forma

$$
u=\frac{T-T_{0}}{h}
$$

Onde $\mathrm{T}_{0}$ é a menor temperatura da tabela e $h$ é o espaçamento não-nulo entre os valores dados. $\mathrm{O}$ valor interpolado das propriedades desejadas fica definido por

$$
P\left(T_{0}+u h\right)=\sum_{k=0}^{n} f_{k} \frac{(u-0)(u-1) \ldots[u-(k-1)][u-(k+1)] \ldots(u-n)}{(k-0)(k-1) \ldots[k-(k-1)][k-(k+1)] \ldots(k-n)}
$$

Onde $f_{k}$ é o valor tabelado de pressão de vapor ou de densidade para cada temperatura dada e $n$ vale 13 .

Tais cálculos foram implementados em uma planilha eletrônica do OpenOffice, versão 2.0.3. Há a célula para entrada com o valor de temperatura, uma intermediária que calcula o valor do parâmetro $u$ (variável que substitui a temperatura), uma coluna para os polinômios $\Lambda_{k}=$ $\frac{\prod_{j} u-j}{\prod_{j} k-j}, j \neq k$ e outra para armazenar os produtos $f_{k} \Lambda_{k}$ usados na interpolação do valor de ambas as propriedades.

Uma ilustração da tabela utilizada está na figura B.1. 


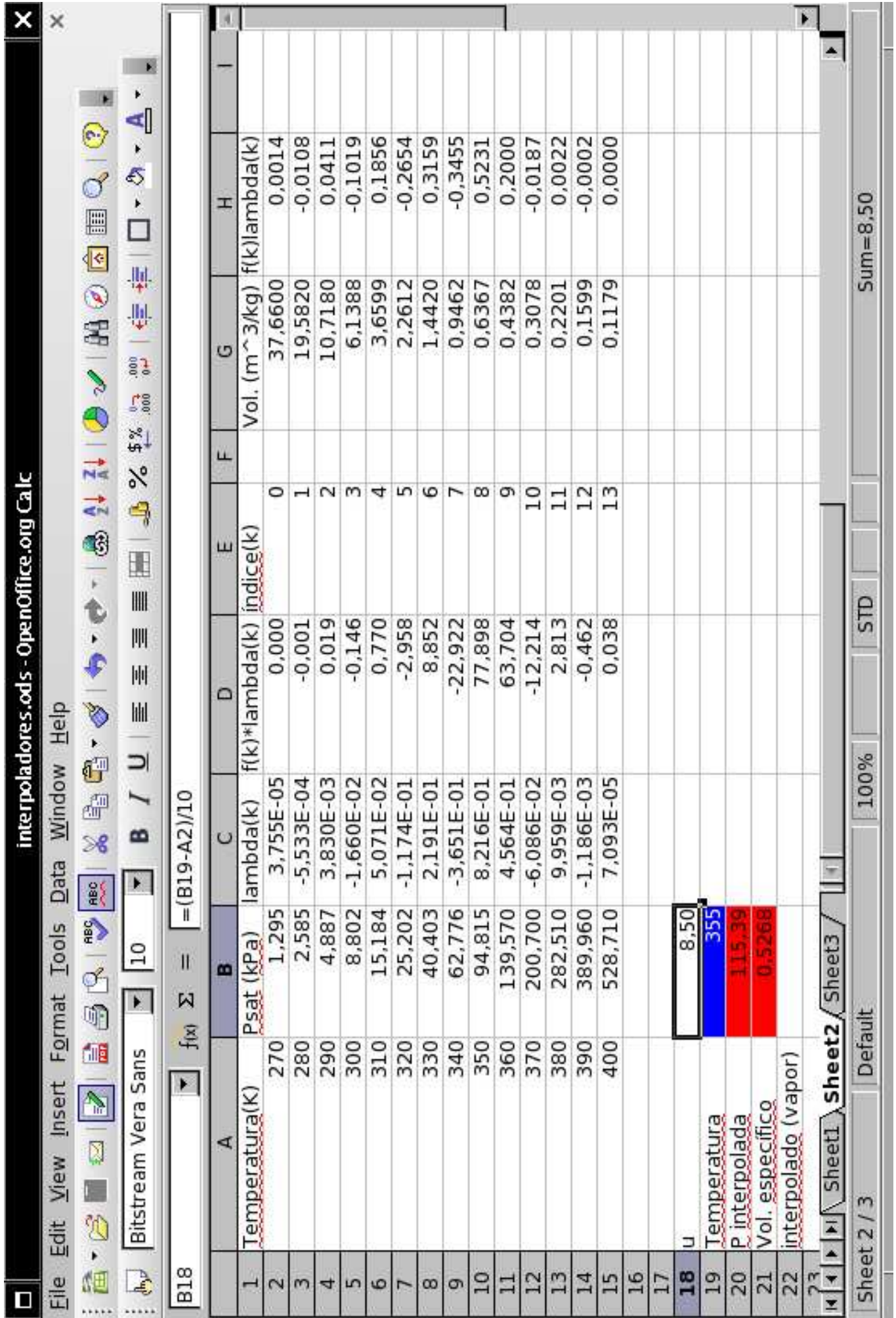

Figura B.1: Planilha eletrônica usada para interpolação de propriedades do etanol saturado. 
Tabela B.1: Pressão de vapor do etanol em função da temperatura.

\begin{tabular}{|c|c|c|}
\hline Temperatura $\left({ }^{\circ} \mathrm{C}\right)$ & Pressão de vapor $(\mathrm{Pa})$ & Dens. de vapor saturado $\left(\mathrm{kg} / \mathrm{m}^{3}\right)$ \\
\hline-3 & 1295 & 0,027 \\
\hline 7 & 2585 & 0,051 \\
\hline 17 & 4887 & 0,093 \\
\hline 27 & 8802 & 0,163 \\
\hline 37 & 15184 & 0,273 \\
\hline 47 & 25202 & 0,442 \\
\hline 57 & 40403 & 0,693 \\
\hline 67 & 62776 & 1,057 \\
\hline 77 & 94815 & 1,571 \\
\hline 87 & 139570 & 2,282 \\
\hline 97 & 200700 & 3,249 \\
\hline 107 & 281570 & 4,543 \\
\hline 117 & 389960 & 6,254 \\
\hline 127 & 528710 & 8,482 \\
\hline
\end{tabular}

Fonte: [50]

\section{B.2 Cálculo das emissões e demais parâmetros referentes ao funcionamento do motor}

Nesta seção são descritas as fórmulas usadas nos cálculos das grandezas apresentadas nas tabelas 4.1 e 4.2 .

Com um peso de 4,030kg sobre a balança da célula de carga, que está a uma distância de $975 \mathrm{~mm}$ (torque de 3,929 kgfm), o medidor acusa um valor de 18,8. Portanto o valor de 1,0kgf.m corresponde a $\frac{18,8}{3,929}=4,784$ no visor da célula de carga, restando a conversão para Newton-metro com a multiplicação pela aceleração da gravidade.

$$
\tau=\frac{\text { (célula de carga) }}{4,784} \times 9,81
$$

Potência: usando fatores de conversão de rpm para rad/s e de Watt para quilowatt temos

$$
P=\frac{\pi \tau \omega}{30000}
$$

Eficiência termodinâmica: usou-se o fator 100 para conversão para porcentual.

$$
\eta=\frac{100 \times P}{\dot{m}_{\text {etanol }} \times \mathrm{PCI}}
$$

Pressão absoluta no coletor de admissão:

$$
\mathrm{MAP}=p_{a b s}-\text { vácuo }_{a d m}
$$


Pressão na caldeira: usou-se fatores de conversão entre os valores lidos nos manômetros em $\mathrm{kgf} / \mathrm{cm}^{2}$ ou $\mathrm{mmHg}$ para a unidade pretendida que é $\mathrm{kPa}$, necessária às verificações de temperatura de saturação.

$$
p_{a b s, \text { cald }}=\frac{p_{a b s} \times 101,325}{760}+p_{\text {cald }} \times 98,1
$$

Consumo médio de etanol: dividiu-se 100 pela média dos tempos para consumo de $100 \mathrm{~g}$ de combustível.

$$
\dot{m}_{\text {etanol }}=\frac{500}{M 1+M 2+M 3+M 4+M 5}
$$

Onde M1 ... M5 são as 5 medidas de tempo de consumo realizadas. Em alguns regimes muito instáveis nos quais não houve tempo hábil para realizar 5 medidas, o numerador 500 foi substituído por 400 ou 300 caso o número de medidas possíveis fosse quatro ou três, respectivamente.

A razão ar/combustível foi calculada para efeito de comparação com os valores fornecidos pelo analisador de gases. Para a razão ar/combustível temos:

$$
\Lambda=\frac{\dot{m}_{a r}}{\dot{m}_{\text {etanol }}}
$$

A razão ar/combustível normalizada pelo seu valor estequiométrico para etanol hidratado é definida por:

$$
\lambda=\frac{\Lambda}{8,33}
$$

Vazão total de produtos de combustão em base seca: deve-se deduzir as três moléculas de vapor d'água geradas na queima de cada molécula de etanol (desprezando-se ineficiências na queima) e transformar a vazão de $\mathrm{g} / \mathrm{s}$ (numerador) para mol/s de acordo com uma massa molar média ponderada das emissões (denominador). Por não haver medição de vazão de gases na saída admite-se que é a mesma de entrada (despreza-se blowby), que é a entrada de massa seca calculada no numerador da equação B.11. Observa-se que o gás nitrogênio $\left(\mathrm{N}_{2}\right)$ não participa dos cálculos.

$$
\mathrm{PCBS}=\frac{\overbrace{\dot{m}_{\text {etanol }} \times(1-0,07)}^{\text {fração anidra }}+0,21 \times \dot{m}_{a r} \frac{M M_{O 2}}{M M_{\text {ar }}}-\overbrace{\left(3 \dot{m}_{\text {etanol }} \frac{M M_{\text {água }}}{M M_{\text {etanol }}}\right)}^{\text {água condensada }}}{\frac{\% C O_{2} \times M M_{C O 2}}{100}+\frac{\% C O \times M M_{C O}}{100}+\frac{p p m C H_{4} \times M M_{C H 4}}{10^{6}}+\frac{\% O_{2} \times M M_{O 2}}{100}+\frac{p p m N O_{x} \times M M_{N O}}{10^{6}}}
$$

Produção de $\mathrm{CO}$ em g/h:

$$
\dot{m}_{C O}=\mathrm{PCBS} \times \frac{\% C O}{100} \times M M_{C O}
$$

Produção de hidrocarbonetos (THC), $\mathrm{CO}_{2}, \mathrm{O}_{2}$, óxidos de nitrogênio $\left(\mathrm{NO}_{x}\right)$; respectivamente, em g/h:

$$
\dot{m}_{T H C}=\mathrm{PCBS} \times \frac{p p m T H C}{10^{6}} \times M M_{C H 4}
$$


Produção de em g/h:

$$
\dot{m}_{C O 2}=\mathrm{PCBS} \times \frac{\% C O 2}{100} \times M M_{C O 2}
$$

Produção de em g/h:

$$
\dot{m}_{O 2}=\mathrm{PCBS} \times \frac{\% O 2}{100} \times M M_{O 2}
$$

Considerando-se que o aparelho de medição çê moléculas de NO:

$$
\dot{m}_{N O_{x}}=\mathrm{PCBS} \times \frac{p p m N O}{10^{6}} \times M M_{N O}
$$

$\mathrm{N}_{2}$ que sai "praticamente ileso", desprezando a pequena parcela que é usada na conversão para NO:

$$
N_{2, \text { circulante }}=\frac{\text { PCBS }}{M M_{a r}} \times 0,79 \times 3600 \times M M_{N 2}
$$

Deve-se tomar o cuidado de não confundir "ar" com "Ar". O primeiro, grafado com letra minúscula, refere-se ao ar atmosférico, enquanto aquele grafado com A maiúsculo refere-se ao gás argônio, presente na atmosfera porém condierado com parte dos $79 \%$ de $\mathrm{N}_{2}$ nos presentes cálculos.

As emissões específicas, ou seja, relacionadas à energia mecânica entregue pelo motor, foram calculadas dividindo-se sua taxa de produção $(\mathrm{g} / \mathrm{h})$ pela potência desenvolvida $(\mathrm{kW})$, obtendo-se a produção específica em $\mathrm{g} / \mathrm{kWh}$ para cada emissão.

$$
\dot{m}_{i, e s p}=\frac{\dot{m}_{i}}{P}
$$

Onde $i$ pode ser qualquer uma das emissões e $\dot{m}_{i}$ representa qualquer emissão descrita das fórmulas B.12 s B.16.

da mesma forma, o consumo específico de etanol é definido por:

$$
\dot{m}_{\text {etanol,esp }}=\frac{\dot{m}_{\text {etanol }}}{P}
$$

A estimativa de vazão de água pelo sistema de arrefecimento foi feita, para auxiliar o entendimento dos fenômenos de transmissão de calor e de perda de cerga na água da caldeira. Trata-se de uma estimativa grosseira, pois as temperaturas medidas e a taxa de produção de vapor de etanol não foram muito estáveis.

$$
\dot{m}_{\mathrm{H} 2 \mathrm{O}, \text { arref }}=\frac{h_{\mathrm{lv}, \mathrm{etanol}} \times \dot{m}_{\mathrm{etanol}}}{c_{p, \mathrm{H} 2 \mathrm{O}} \times\left(T_{\mathrm{ent}, \mathrm{rad}}-T_{\text {sai,rad }}\right)}
$$

O índice $\mathrm{rad}$ refere-se ao radiador.

Para investigar as influências nas emissões de $\mathrm{NO}_{x}$ foi calculado o tempo entre a ignição e o momento em que o pistão atinge o PMS. Esse tempo (em milissegundos) leva em conta o 
tempo para o virabrequim realizar uma volta (inverso do número de voltas dadas num segundo, multiplicado por 1000) e a fração de volta correspondente ao ângulo de avanço da ignição.

$$
t_{\text {ign-PMS }}=\frac{60}{0,001 \omega} \times \frac{{ }^{\circ} A P M S}{360^{\circ}}=\frac{{ }^{\circ} \mathrm{APMS}}{0,006 \omega}
$$




\section{Apêndice C}

\section{Dados coletados}

\section{C.1 Aquecimento do motor}

A tabela C. 1 contém os dados coletados pelo sistema de aquisição de temperaturas, além da pressão observada na caleira durante os ensaios de aquecimento transiente (seção 4.4).

Tabela C.1: Ensaios de aquecimento transiente.

\begin{tabular}{|c|c|c|c|c|c|c|c|c|c|}
\hline \multirow{2}{*}{$\begin{array}{l}\text { Tempo de } \\
\text { trabalho } \\
\text { (s) }\end{array}$} & \multicolumn{4}{|c|}{ Com válvula termostética } & \multicolumn{4}{|c|}{ Sem válvula termostática } & \multirow[t]{2}{*}{ Obs.: } \\
\hline & $\begin{array}{c}\text { Entrada } \\
\left({ }^{\circ} \mathrm{C}\right)\end{array}$ & $\begin{array}{c}\text { Saída } \\
\left({ }^{\circ} \mathrm{C}\right)\end{array}$ & $\begin{array}{l}\text { Óleo } \\
\left({ }^{\circ} \mathrm{C}\right)\end{array}$ & $\begin{array}{c}\text { Pressão } \\
\left(\mathrm{kgf} / \mathrm{cm}^{2}\right)\end{array}$ & $\begin{array}{c}\text { Entrada } \\
\left({ }^{\circ} \mathrm{C}\right)\end{array}$ & $\begin{array}{c}\text { Saída } \\
\left({ }^{\circ} \mathrm{C}\right)\end{array}$ & $\begin{array}{l}\text { Óleo } \\
\left({ }^{\circ} \mathrm{C}\right)\end{array}$ & $\begin{array}{c}\text { Pressão } \\
\left(\mathrm{kgf} / \mathrm{cm}^{2}\right)\end{array}$ & \\
\hline 0 & 20,4 & 20,5 & 20,8 & 0,00 & 29,7 & 28,6 & 22,8 & 0,00 & $\operatorname{Inj}=2,56 \mathrm{~ms}(\mathrm{c})$ \\
\hline 5 & 20,4 & 20,5 & 20,8 & & 30,1 & 29,1 & 23,0 & & $2,39 \mathrm{~ms}(\mathrm{~s})$ \\
\hline 10 & 20,5 & 20,5 & 20,8 & & 30,7 & 29,8 & 23,3 & & \\
\hline 15 & 20,5 & 20,5 & 20,8 & & 31,2 & 30,4 & 23,7 & & \\
\hline 20 & 20,5 & 20,5 & 20,8 & & 31,8 & 31,0 & 24,2 & & \\
\hline 25 & 20,4 & 20,5 & 20,8 & & 32,5 & 31,6 & 24,5 & & \\
\hline 30 & 20,4 & 20,5 & 20,8 & & 33,0 & 32,1 & 24,9 & & \\
\hline 35 & 20,5 & 20,5 & 20,8 & & 33,6 & 32,7 & 25,3 & & \\
\hline 40 & 20,5 & 20,5 & 20,8 & & 34,2 & 33,3 & 25,6 & & \\
\hline 45 & 20,5 & 20,5 & 20,8 & & 34,8 & 33,9 & 26,1 & & \\
\hline 50 & 20,4 & 20,5 & 20,8 & & 35,4 & 34,5 & 26,7 & & \\
\hline 55 & 20,5 & 20,5 & 20,8 & & 36,0 & 35,0 & 27,2 & & \\
\hline 60 & 20,5 & 20,5 & 20,8 & & 36,5 & 35,6 & 27,9 & & célula=3,7(s) \\
\hline 65 & 20,4 & 20,5 & 20,8 & & 37,1 & 36,2 & 28,8 & & \\
\hline 70 & 20,5 & 20,5 & 20,8 & & 37,7 & 36,8 & 29,5 & & \\
\hline 75 & 20,4 & 20,5 & 20,8 & & 38,3 & 37,3 & 30,2 & & \\
\hline 80 & 20,4 & 20,5 & 20,9 & & 38,8 & 37,9 & 30,9 & & \\
\hline 85 & 20,4 & 20,5 & 20,9 & & 39,4 & 38,5 & 31,5 & & \\
\hline 90 & 20,4 & 20,5 & 20,9 & & 40,0 & 39,0 & 32,0 & & \\
\hline 95 & 20,5 & 20,5 & 20,9 & & 40,5 & 39,6 & 32,6 & & \\
\hline 100 & 20,5 & 20,5 & 21,0 & & 41,1 & 40,2 & 33,3 & & \\
\hline 105 & 20,5 & 20,5 & 21,1 & & 41,6 & 40,7 & 33,9 & & \\
\hline 110 & 20,5 & 20,5 & 21,2 & & 42,1 & 41,2 & 34,4 & & \\
\hline 115 & 20,5 & 20,5 & 21,3 & & 42,7 & 41,8 & 35,1 & & \\
\hline
\end{tabular}

Continua 
Continuação

\begin{tabular}{|c|c|c|c|c|c|c|c|}
\hline 120 & 20,4 & 20,5 & 21,4 & 43,3 & 42,3 & 36,0 & \\
\hline 125 & 20,5 & 20,5 & 21,5 & 43,8 & 42,9 & 36,6 & \\
\hline 130 & 20,5 & 20,5 & 21,7 & 44,4 & 43,4 & 37,2 & \\
\hline 135 & 20,5 & 20,5 & 21,8 & 44,9 & 44,0 & 37,9 & \\
\hline 140 & 20,5 & 20,5 & 22,1 & 45,4 & 44,5 & 38,6 & \\
\hline 145 & 20,5 & 20,5 & 22,4 & 46,0 & 45,0 & 39,3 & \\
\hline 150 & 20,5 & 20,5 & 22,9 & 46,5 & 45,6 & 39,8 & $2,82 \mathrm{~ms}(\mathrm{c})$ \\
\hline 155 & 20,5 & 20,5 & 23,5 & 47,1 & 46,1 & 40,4 & $\mathrm{c}=4,6(\mathrm{c})$ \\
\hline 160 & 20,5 & 20,5 & 24,1 & 47,6 & 46,7 & 40,9 & $\mathrm{c}=5,3(\mathrm{~s})$ \\
\hline 165 & 20,5 & 20,5 & 24,8 & 48,2 & 47,2 & 41,3 & \\
\hline 170 & 20,5 & 20,5 & 25,5 & 48,7 & 47,7 & 41,8 & \\
\hline 175 & 20,5 & 20,6 & 26,0 & 49,3 & 48,3 & 42,3 & \\
\hline 180 & 20,5 & 20,5 & 26,6 & 49,8 & 48,8 & 42,9 & \\
\hline 185 & 20,5 & 20,5 & 27,3 & 50,3 & 49,4 & 43,5 & \\
\hline 190 & 20,5 & 20,6 & 28,1 & 50,9 & 49,9 & 44,0 & \\
\hline 195 & 20,5 & 20,6 & 28,7 & 51,4 & 50,5 & 44,6 & $2,49 \mathrm{~ms}(\mathrm{c})$ \\
\hline 200 & 20,5 & 20,6 & 29,3 & 52,0 & 51,0 & 45,1 & $\mathrm{c}=4,6(\mathrm{c})$ \\
\hline 205 & 20,5 & 20,6 & 30,1 & 52,5 & 51,5 & 45,6 & \\
\hline 210 & 20,5 & 20,6 & 30,8 & 53,1 & 52,1 & 46,2 & \\
\hline 215 & 20,5 & 20,5 & 31,3 & 53,6 & 52,6 & 46,9 & \\
\hline 220 & 20,5 & 20,5 & 31,8 & 54,1 & 53,1 & 47,5 & \\
\hline 225 & 20,5 & 20,5 & 32,4 & 54,6 & 53,6 & 48,0 & \\
\hline 230 & 20,5 & 20,6 & 32,9 & 55,1 & 54,1 & 48,5 & \\
\hline 235 & 20,5 & 20,6 & 33,5 & 55,7 & 54,7 & 49,1 & \\
\hline 240 & 20,5 & 20,6 & 34,4 & 56,2 & 55,2 & 49,5 & \\
\hline 245 & 20,5 & 20,6 & 35,4 & 56,7 & 55,7 & 49,9 & \\
\hline 250 & 20,5 & 20,6 & 36,4 & 57,2 & 56,3 & 50,2 & $\mathrm{c}=5,9(\mathrm{~s})$ \\
\hline 255 & 20,5 & 20,6 & 37,3 & 57,7 & 56,8 & 50,5 & \\
\hline 260 & 20,5 & 20,6 & 38,0 & 58,2 & 57,3 & 50,7 & \\
\hline 265 & 20,5 & 20,6 & 38,6 & 58,7 & 57,8 & 51,0 & \\
\hline 270 & 20,6 & 20,5 & 39,3 & 59,2 & 58,3 & 51,4 & $\mathrm{c}=5,8(\mathrm{c})$ \\
\hline 275 & 20,6 & 20,5 & 40,1 & 59,7 & 58,8 & 51,8 & \\
\hline 280 & 20,7 & 20,5 & 40,9 & 60,3 & 59,3 & 52,2 & \\
\hline 285 & 20,6 & 20,5 & 41,7 & 60,8 & 59,8 & 52,5 & \\
\hline 290 & 39,4 & 20,5 & 42,6 & 61,3 & 60,3 & 52,8 & \\
\hline 295 & 47,2 & 20,5 & 43,6 & 61,8 & 60,8 & 53,2 & \\
\hline 300 & 56,0 & 20,5 & 44,4 & 62,3 & 61,3 & 53,5 & $\mathrm{c}=6,1(\mathrm{~s})$ \\
\hline 305 & 61,9 & 20,6 & 45,2 & 62,8 & 61,8 & 53,9 & \\
\hline 310 & 63,8 & 20,8 & 46,0 & 63,3 & 62,3 & 54,4 & \\
\hline 315 & 66,4 & 21,3 & 46,7 & 63,7 & 62,7 & 54,7 & \\
\hline 320 & 68,9 & 22,4 & 47,3 & 64,2 & 63,2 & 55,1 & \\
\hline 325 & 70,3 & 24,4 & 47,9 & 64,7 & 63,8 & 55,5 & \\
\hline 330 & 70,9 & 26,6 & 48,7 & 65,2 & 64,2 & 55,9 & $\mathrm{c}=6,8(\mathrm{c})$ \\
\hline 335 & 72,5 & 29,2 & 49,5 & 65,7 & 64,7 & 56,3 & \\
\hline 340 & 73,3 & 31,7 & 50,3 & 66,2 & 65,2 & 56,6 & \\
\hline 345 & 73,8 & 33,8 & 51,1 & 66,7 & 65,7 & 56,9 & \\
\hline 350 & 74,6 & 36,0 & 51,6 & 67,1 & 66,2 & 57,3 & \\
\hline
\end{tabular}

Continua 
Continuação

\begin{tabular}{|c|c|c|c|c|c|c|c|c|}
\hline 355 & 75,2 & 38,9 & 52,1 & 67,6 & 66,6 & 57,6 & & \\
\hline 360 & 75,9 & 41,9 & 52,7 & 68,1 & 67,1 & 57,9 & & \\
\hline 365 & 76,1 & 44,4 & 53,2 & 68,6 & 67,6 & 58,2 & & \\
\hline 370 & 76,4 & 46,4 & 53,8 & 69,1 & 68,1 & 58,5 & & $\mathrm{c}=6,4(\mathrm{~s})$ \\
\hline 375 & 77,3 & 48,6 & 54,4 & 69,5 & 68,6 & 58,9 & & \\
\hline 380 & 77,2 & 50,7 & 54,8 & 70,0 & 69,1 & 59,2 & & \\
\hline 385 & 77,7 & 52,5 & 55,4 & 70,5 & 69,5 & 59,6 & & \\
\hline 390 & 77,9 & 54,2 & 55,9 & 71,0 & 69,9 & 60,0 & & $\mathrm{c}=7,0(\mathrm{c})$ \\
\hline 395 & 78,1 & 55,8 & 56,4 & 71,4 & 70,4 & 60,3 & & \\
\hline 400 & 78,5 & 57,1 & 56,9 & 71,8 & 70,9 & 60,6 & & \\
\hline 405 & 78,8 & 58,3 & 57,3 & 72,3 & 71,3 & 61,0 & & \\
\hline$\overline{410}$ & 79,2 & 59,4 & 57,9 & $\overline{72,8}$ & 71,8 & 61,4 & & \\
\hline 415 & 79,4 & 60,4 & 58,3 & 73,2 & 72,3 & 61,6 & & \\
\hline$\overline{420}$ & 79,6 & 61,2 & 58,8 & 73,7 & 72,7 & 61,9 & & \\
\hline 425 & 79,7 & 62,0 & 59,3 & 74,2 & 73,2 & 62,3 & & \\
\hline 430 & 79,9 & 62,8 & 59,8 & 74,6 & 73,6 & 62,7 & & \\
\hline 435 & 79,9 & 63,4 & 60,3 & $\overline{75,0}$ & 74,1 & 63,0 & & \\
\hline 440 & 80,2 & 64,0 & 60,8 & 75,5 & 74,6 & 63,4 & & \\
\hline 445 & 80,0 & 64,7 & 61,3 & 76,0 & 75,0 & 63,8 & & \\
\hline 450 & 80,3 & 65,4 & $\begin{array}{ll}61,8 \\
\end{array}$ & 76,3 & 75,4 & 64,1 & & \\
\hline 455 & 80,6 & 65,9 & 62,2 & 76,9 & 75,9 & 64,5 & & \\
\hline 460 & 80,7 & 66,3 & 62,7 & 77,3 & 76,4 & 64,8 & & \\
\hline 465 & 80,6 & 66,8 & 63,3 & 77,7 & 76,8 & 65,1 & & \\
\hline 470 & 80,9 & 67,3 & 63,8 & 78,2 & 77,3 & 65,5 & & $\mathrm{c}=7,4(\mathrm{c})$ \\
\hline 475 & 80,7 & 67,7 & 64,3 & 78,6 & 77,7 & 65,8 & & \\
\hline 480 & 81,1 & 68,1 & 64,7 & 79,1 & 78,1 & 66,2 & & \\
\hline 485 & 81,0 & 68,5 & 65,1 & 79,5 & 78,5 & 66,5 & & \\
\hline 490 & 81,2 & 68,9 & 65,6 & 79,9 & 79,0 & 66,8 & & \\
\hline 495 & 81,2 & 69,2 & 65,9 & 80,4 & 79,4 & 67,2 & & \\
\hline 500 & 81,2 & 69,6 & 66,3 & 80,8 & 79,8 & 67,5 & & \\
\hline 505 & 81,4 & 70,0 & 66,7 & 81,2 & 80,3 & 67,8 & & \\
\hline 510 & 81,6 & 70,3 & 67,1 & 81,7 & 80,8 & 68,1 & & \\
\hline 515 & 81,8 & 70,6 & 67,5 & 82,1 & 81,2 & 68,4 & & \\
\hline 520 & 81,8 & 70,8 & 67,9 & 82,6 & 81,6 & 68,8 & & $\mathrm{c}=7,2(\mathrm{~s})$ \\
\hline 525 & 81,7 & 71,2 & 68,3 & 83,0 & 82,0 & 69,1 & & \\
\hline 530 & 81,7 & 71,5 & 68,7 & 83,4 & 82,5 & 69,4 & & \\
\hline 535 & 81,8 & 71,8 & 69,1 & 83,8 & 82,8 & 69,8 & & \\
\hline 540 & 82,0 & 72,1 & 69,5 & 84,2 & 83,2 & 70,2 & & \\
\hline 545 & 81,9 & 72,4 & 69,8 & 84,7 & 83,6 & 70,6 & & \\
\hline$\overline{550}$ & 82,0 & 72,6 & 70,2 & 85,1 & 84,0 & 71,0 & & \\
\hline 555 & 82,1 & 72,8 & 70,6 & 85,5 & 84,5 & 71,4 & & \\
\hline 560 & 82,1 & 73,1 & 71,0 & 85,9 & 84,9 & 71,7 & & \\
\hline 565 & 82,2 & 73,4 & 71,3 & 86,3 & 85,3 & 72,0 & & \\
\hline 570 & 82,3 & 73,8 & 71,6 & 86,8 & 85,7 & 72,4 & & \\
\hline 575 & 82,2 & 74,1 & 71,8 & 87,1 & 86,1 & 72,7 & & \\
\hline 580 & 82,4 & 74,5 & 72,1 & 87,5 & 86,5 & 73,0 & 0,05 & $\mathrm{c}=7,2(\mathrm{~s})$ \\
\hline 585 & 82,5 & 74,9 & 72,5 & 87,9 & 86,9 & 73,4 & & \\
\hline
\end{tabular}

Continua 
Continuação

\begin{tabular}{|c|c|c|c|c|c|c|c|c|c|}
\hline 590 & 82,6 & 75,3 & 72,9 & & 88,3 & 87,3 & 73,7 & & \\
\hline 595 & 82,6 & 75,6 & 73,3 & & 88,7 & 87,7 & 74,1 & & \\
\hline 600 & 82,7 & 75,9 & 73,5 & & 89,1 & 88,0 & $\overline{74,4}$ & 0,10 & $1,51 \mathrm{~ms}(\mathrm{~s})$ \\
\hline 605 & 82,8 & 76,4 & 73,9 & & 89,4 & 88,5 & 74,7 & & $\mathrm{c}=6,5(\mathrm{~s})$ \\
\hline 610 & 82,8 & 76,9 & 74,3 & & 89,8 & 88,9 & 75,0 & & \\
\hline 615 & 82,9 & 77,3 & 74,6 & & 90,2 & 89,3 & 75,4 & & \\
\hline 620 & 83,0 & 77,7 & 74,9 & & 90,6 & 89,7 & 75,8 & 0,15 & \\
\hline 625 & 83,1 & 78,0 & 75,2 & & 91,0 & 90,0 & 76,1 & & $\mathrm{c}=6,8(\mathrm{~s})$ \\
\hline 630 & 83,3 & 78,4 & 75,5 & & 91,3 & $\overline{90,4}$ & 76,4 & & \\
\hline 635 & 83,3 & 78,7 & 75,8 & & 91,8 & 90,8 & 76,8 & & \\
\hline 640 & 83,4 & 79,0 & 76,0 & & 92,1 & 91,1 & 77,1 & 0,20 & $\mathrm{c}=7,0(\mathrm{~s})$ \\
\hline 645 & 83,5 & 79,3 & 76,3 & & 92,5 & 91,5 & 77,5 & & \\
\hline 650 & 83,6 & 79,5 & 76,6 & & 92,9 & 91,9 & 77,8 & & \\
\hline 655 & 83,7 & 79,8 & 76,8 & & 93,3 & 92,2 & 78,2 & & \\
\hline 660 & 83,9 & 80,1 & 77,0 & & 93,7 & 92,6 & 78,5 & 0,30 & $\mathrm{c}=7,2(\mathrm{~s})$ \\
\hline 665 & 84,0 & 80,4 & 77,2 & & 94,0 & 93,0 & 78,8 & & $c=7,6(c)$ \\
\hline 670 & 84,1 & 80,6 & 77,5 & & 94,5 & 93,3 & 79,2 & & \\
\hline 675 & 84,2 & 80,9 & 77,7 & & 94,8 & 93,7 & 79,4 & & \\
\hline 680 & 84,3 & 81,1 & 78,0 & & 95,1 & 94,1 & 79,7 & 0,45 & $1,26 \mathrm{~ms}(\mathrm{~s})$ \\
\hline 685 & 84,4 & 81,3 & 78,3 & & 95,6 & 94,5 & 80,0 & & $\mathrm{c}=6,9(\mathrm{~s})$ \\
\hline 690 & 84,6 & 81,6 & 78,5 & & 95,9 & 94,9 & 80,4 & & \\
\hline 695 & 84,7 & 81,9 & 78,6 & & 96,3 & 95,2 & 80,7 & 0,55 & $\mathrm{c}=7,0(\mathrm{~s})$ \\
\hline 700 & 84,8 & 82,2 & 78,9 & & 96,7 & 95,6 & 81,0 & 0,55 & \\
\hline 705 & 85,0 & 82,5 & 79,1 & & 97,1 & 96,0 & 81,3 & 0,55 & ligou ventoinha(s) \\
\hline 710 & 85,2 & 82,8 & 79,4 & & $\overline{97,6}$ & 96,4 & 81,7 & 0,55 & $\mathrm{c}=7,8(\mathrm{c})$ \\
\hline 715 & 85,3 & 83,1 & 79,7 & & 96,5 & 96,7 & 82,0 & 0,55 & \\
\hline 720 & 85,5 & 83,4 & 80,0 & & 95,7 & 96,3 & 82,4 & 0,55 & \\
\hline 725 & 85,7 & 83,7 & 80,3 & & 95,3 & 95,5 & 82,7 & 0,55 & \\
\hline 730 & 85,7 & 84,1 & 80,7 & & $\overline{94,5}$ & 94,9 & 83,0 & 0,55 & \\
\hline 735 & 85,8 & 84,3 & 80,8 & & 93,7 & 94,3 & 83,3 & 0,55 & \\
\hline 740 & 85,8 & 84,6 & 81,0 & & 92,9 & 93,5 & 83,5 & 0,55 & \\
\hline 745 & 86,0 & 84,7 & 81,2 & & 92,2 & 92,8 & 83,6 & 0,55 & \\
\hline 750 & 86,4 & 85,0 & 81,4 & & 91,4 & 92,0 & 83,8 & 0,55 & $1,29 \mathrm{~ms}(\mathrm{c})$ \\
\hline 755 & 86,7 & 85,3 & 81,6 & & 90,7 & 91,3 & 84,0 & 0,55 & $\mathrm{c}=6,8(\mathrm{c})$ \\
\hline 760 & 87,0 & 85,7 & 81,8 & & 90,1 & 90,6 & 84,2 & 0,55 & \\
\hline 765 & 87,2 & 86,1 & 82,0 & & 89,4 & 90,0 & 84,3 & 0,55 & \\
\hline 770 & 87,6 & 86,4 & 82,3 & & & & & & \\
\hline 775 & 87,9 & 86,7 & 82,6 & & & & & & \\
\hline 780 & 88,3 & 87,0 & 82,8 & 0,05 & & & & & $\mathrm{c}=4,9(\mathrm{c})$ \\
\hline 785 & 88,6 & 87,4 & 83,1 & & & & & & \\
\hline 790 & 88,8 & 87,7 & 83,4 & & & & & & \\
\hline 795 & 89,1 & 88,0 & 83,5 & & & & & & \\
\hline 800 & 89,2 & 88,2 & 83,6 & 0,15 & & & & & $0,26 \mathrm{~ms}(\mathrm{c})$ \\
\hline 805 & 89,5 & 88,4 & 83,8 & & & & & & $\mathrm{c}=1,0(\mathrm{c})$ \\
\hline 810 & 89,7 & 88,6 & 83,9 & & & & & & \\
\hline 815 & 89,9 & 88,9 & 83,9 & & & & & & \\
\hline 820 & 90,0 & 89,0 & 84,0 & & & & & & \\
\hline
\end{tabular}

Continua 
Conclusão

\begin{tabular}{|l|l|l|l|l||l|l|l|l|l|}
\hline 825 & 90,3 & 89,2 & 84,0 & 0,20 & & & & & $|\boldsymbol{\phi}|=36,75 \%(\mathrm{c})$ \\
\hline 830 & 90,7 & 89,4 & 84,1 & & & & & & $\mathrm{c}=21,0(\mathrm{c})$ \\
\hline 835 & 91,1 & 89,7 & 83,9 & & & & & & \\
\hline 840 & 91,4 & 90,1 & 83,1 & & & & & & $\mathrm{c}=4,6(\mathrm{c})$ \\
\hline 845 & 91,9 & 90,5 & 82,7 & & & & & & \\
\hline 850 & 92,4 & 90,9 & 82,6 & & & & & & \\
\hline 855 & 93,0 & 91,4 & 82,9 & & & & & & \\
\hline 860 & 93,5 & 91,9 & 84,0 & 0,35 & & & & & \\
\hline 865 & 94,1 & 92,4 & 84,3 & & & & & & $\mathrm{c}=24,9(\mathrm{c})$ \\
\hline 870 & 94,7 & 92,9 & 84,8 & & & & & & \\
\hline 875 & 95,4 & 93,5 & 85,5 & & & & & & \\
\hline 880 & 96,1 & 94,1 & 86,0 & & & & & & \\
\hline 885 & 96,9 & 94,9 & 86,4 & 0,45 & & & & & ligou ventoinha \\
\hline 890 & 97,7 & 95,6 & 86,7 & & & & & & $\mathrm{c}=28,8(\mathrm{c})$ \\
\hline 895 & 96,6 & 96,1 & 87,0 & & & & & & \\
\hline 900 & 96,2 & 95,9 & 87,3 & & & & & & \\
\hline 905 & 96,0 & 95,4 & 87,5 & & & & & & comutação \\
\hline 910 & 95,7 & 95,1 & 87,5 & & & & & & $\mathrm{c}=12,7(\mathrm{c})$ \\
\hline 915 & 94,4 & 94,7 & 85,3 & & & & & & \\
\hline 920 & 93,9 & 94,0 & 82,5 & 0,50 & & & & & \\
\hline 925 & 93,3 & 93,3 & 81,6 & 0,50 & & & & & \\
\hline 930 & 92,8 & 92,7 & 81,5 & 0,50 & & & & & \\
\hline 935 & 92,2 & 92,2 & 81,6 & 0,50 & & & & & \\
\hline 940 & 91,7 & 91,7 & 82,0 & 0,50 & & & & & \\
\hline
\end{tabular}

\section{C.2 Ensaios dinamométricos}

Antes de se realizar os ensaios com o sistema de fornecimento de vapor o motor foi ensaiado com sua ECU original, para efeito de comparação. Os resultados das medições de consumo de combustível estão na tabela C.3, enquanto as demais medidas estão na tabela C.2.

Para o funcionamento dom álcool vaporizado, as medidas de consumo estão nas tabelas C.4 e C.5. 
Tabela C.2: Dados colhidos em ECU original (exceto consumo).

\begin{tabular}{|c|c|c|c|c|c|c|c|c|c|c|c|c|c|c|c|c|}
\hline \multirow{2}{*}{$\begin{array}{c}\omega \\
(\mathrm{rpm})\end{array}$} & \multirow{2}{*}{$\begin{array}{l}\mathrm{CO} \\
(\%)\end{array}$} & \multirow{2}{*}{$\begin{array}{l}\text { THC } \\
(\mathrm{ppm})\end{array}$} & \multirow{2}{*}{$\begin{array}{l}\mathrm{NO}_{x} \\
(\mathrm{ppm})\end{array}$} & \multirow{2}{*}{$\begin{array}{l}\mathrm{CO}_{2} \\
(\%)\end{array}$} & \multirow{2}{*}{$\begin{array}{l}\mathrm{O}_{2} \\
(\%)\end{array}$} & \multirow{2}{*}{$\begin{array}{l}\text { Pulso } \\
\text { inj.(ms) }\end{array}$} & \multirow{2}{*}{$\begin{array}{l}\text { Ignição } \\
{ }^{\circ} \text { APMS }\end{array}$} & \multicolumn{4}{|c|}{ Temperaturas $\left({ }^{\circ} \mathrm{C}\right)$} & \multirow{2}{*}{$\begin{array}{c}\text { Consumo } \\
\operatorname{ar}(\mathrm{g} / \mathrm{s})\end{array}$} & \multicolumn{3}{|c|}{ Pressão/vácuo (mm coluna) } & \multirow{2}{*}{$\begin{array}{l}\text { Célula } \\
\text { de carga }\end{array}$} \\
\hline & & & & & & & & Adm. & Escape & TBS & TBU & & Adm.(Hg) & Esc. $\left(\mathrm{H}_{2} \mathrm{O}\right)$ & Abs.(Hg) & \\
\hline 840 & 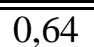 & 349 & 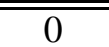 & $\overline{12,5}$ & 2,69 & 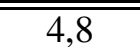 & 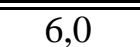 & 45,3 & 195,8 & 22,0 & 20,0 & 2,40 & 350 & 15 & (696,0 & (20,0 \\
\hline 2000 & 0,32 & 109 & 1933 & 25,4 & 0,69 & $\overline{7,4}$ & 18,7 & 92,8 & 312,5 & 21,0 & 19,0 & 9,11 & 180 & 120 & 693,5 & 21,0 \\
\hline 3000 & 0,34 & 233 & 1942 & 14,5 & 0,69 & 5,6 & 18,6 & 51,6 & 259,4 & 21,0 & 19,0 & 10,56 & 310 & 75 & 693,5 & 13,7 \\
\hline 4000 & 0,45 & 431 & 1203 & 14,2 & 0,81 & 4,1 & 22,1 & 51,4 & 290,6 & 21,0 & 19,0 & 10,80 & 440 & 85 & 693,5 & 6,0 \\
\hline 3000 & 0,30 & 387 & 1956 & 14,3 & 0,77 & 10,7 & 14,2 & 57,6 & 423,5 & 21,0 & 19,0 & 208,6 & 120 & 350 & 693,5 & 33,9 \\
\hline 4000 & 0,38 & 849 & 2961 & 14,1 & 0,85 & 11,1 & 13,7 & 49,5 & 424,0 & 21,0 & 19,0 & 28,59 & 50 & 665 & 693,5 & 32,6 \\
\hline \multicolumn{17}{|c|}{ WOT (82 graus) } \\
\hline 2000 & 3,12 & 724 & 997 & 12,9 & 0,32 & 11,7 & 15,8 & 50,1 & 293,4 & 22,0 & 20,0 & 13,49 & 10 & 190 & 696,0 & 32,7 \\
\hline 3000 & 3,36 & 568 & 758 & 12,8 & 0,26 & 12,6 & 14,0 & 48,3 & 694,0 & 22,0 & 20,0 & 21,76 & 18 & 260 & 696,0 & 35,9 \\
\hline 4000 & 2,46 & 370 & 1262 & 12,3 & 0,31 & 13,0 & 13,6 & 49,5 & 398,3 & 22,0 & 20,0 & 31,01 & 20 & 350 & 696,0 & 37,5 \\
\hline
\end{tabular}


Tabela C.3: Consumo de combustível com ECU original.

\begin{tabular}{|c|c|c|c|}
\hline & $2000 \mathrm{rpm}$ & $3000 \mathrm{rpm}$ & $4000 \mathrm{rpm}$ \\
\hline & 87,8 & 79,1 & 80,7 \\
$\left(23^{\circ}\right)$ & 87,8 & 78,7 & 82,1 \\
& 91,4 & 79,9 & 79,9 \\
& 87,4 & 80,0 & 77,8 \\
& 88,3 & 80,9 & 76,9 \\
\hline \hline Média & 88,54 & 79,72 & 79,48 \\
\hline \hline & 66,9 & 42,3 & 30,5 \\
$\left(45^{\circ}\right)$ & 66,2 & 40,8 & 30,5 \\
& 66,0 & 41,7 & 29,7 \\
& 66,1 & 41,1 & 30,0 \\
\hline \hline Média & 67,2 & 40,8 & 30,5 \\
\hline \hline & 66,48 & 41,34 & 30,24 \\
Máxima & 56,9 & 34,8 & 24,7 \\
$\left(82^{\circ}\right)$ & 56,0 & 34,8 & 25,2 \\
& 56,7 & 34,6 & 24,8 \\
& 56,3 & 35,0 & 25,2 \\
& 56,52 & 34,80 & 25,4 \\
\hline \hline Média & 382,6 & & \\
\hline \hline & 378,4 & & \\
Marcha lenta & 373,3 & & \\
$(840 r p m)$ & 373,1 & & \\
& 384,4 & & \\
\hline \hline Média & 378,36 & & \\
\hline & & & \\
\hline
\end{tabular}


Tabela C.4: Medidas de pressão, consumo de combustível e de ar em diversos regimes de operação com combustível vaporizado.

\begin{tabular}{|c|c|c|c|c|c|c|c|c|c|c|c|c|c|c|}
\hline \multirow{2}{*}{$\begin{array}{c}\omega \\
(\mathrm{rpm})\end{array}$} & \multirow{2}{*}{$\begin{array}{l}|\phi| \\
(\%)\end{array}$} & \multirow[t]{2}{*}{$\lambda$} & \multirow{2}{*}{$\begin{array}{l}\text { Ignição } \\
{ }^{\circ} \text { APMS }\end{array}$} & \multicolumn{4}{|l|}{ Pressão } & \multicolumn{5}{|c|}{ Consumo de etanol $(\mathrm{s} / 100 \mathrm{~g})$ - medidas } & \multirow{2}{*}{$\begin{array}{l}\text { Consumo de } \\
\operatorname{ar}(\mathrm{g} / \mathrm{s})\end{array}$} & \multirow{2}{*}{$\begin{array}{c}\text { Célula de } \\
\text { carga }\end{array}$} \\
\hline & & & & $\mathrm{Adm}^{\diamond}$ & Escape $^{\dagger}$ & Absoluta & Caldeira $^{\S}$ & 1 & 2 & 3 & 4 & 5 & & \\
\hline 2000 & 24,25 & 1,00 & 21,4 & 202 & 70 & 695,6 & 0,60 & 89,3 & 90,4 & 91,7 & 92,7 & 91,9 & 8,95 & 20,5 \\
\hline 2000 & 26,25 & 1,01 & 19,8 & 192 & 70 & & 0,75 & 94,0 & 103,3 & 102,2 & 92,9 & 87,8 & 8,94 & 21,0 \\
\hline 2000 & 41,25 & 1,19 & 17,4 & 68 & 130 & 694,7 & 0,75 & 84,4 & 78,6 & 87,9 & 78,2 & 80,4 & 12,31 & 27,8 \\
\hline 2000 & 57,75 & 1,30 & 18,9 & 20 & 131 & 694,7 & 0,70 & $\overline{79,1}$ & 78,4 & 74,9 & 77,8 & $\overline{77,1}$ & 12,90 & 26,2 \\
\hline 2000 & 35,50 & 1,36 & 19,5 & 70 & 85 & 694,1 & 0,65 & 92,0 & 87,9 & 87,4 & 86,6 & 88,4 & 12,04 & 22,4 \\
\hline 2000 & 40,50 & 1,48 & 21,7 & 39 & 175 & & 0,60 & 90,7 & 94,6 & 90,3 & 91,3 & 91,9 & 13,8 & 21,2 \\
\hline 2000 & 53,00 & 1,01 & 13,9 & 20 & 185 & $\begin{array}{l}693,6 \\
\end{array}$ & 0,60 & 64,2 & 62,4 & 62,5 & 61,8 & 62,1 & 12,63 & 32,5 \\
\hline 2000 & 100,00 & 1,01 & 13,4 & 10 & 190 & & 0,60 & 64,1 & 63,2 & 63,9 & 63,3 & 63,5 & 12,75 & 32,3 \\
\hline 3000 & 24,50 & 1,01 & 26,9 & 338 & 145 & $\begin{array}{l}693,4 \\
\end{array}$ & 0,70 & 83,2 & 84,2 & 83,3 & 83,9 & 84,9 & 9,73 & 12,4 \\
\hline 3000 & 30,75 & 1,23 & 29,1 & 281 & 150 & & 0,70 & 84,8 & 84,0 & 83,5 & 83,4 & 82,7 & 11,82 & 13,7 \\
\hline 3000 & 31,75 & 1,31 & 24,7 & 255 & 15 & & 0,73 & 82,6 & 80,8 & 81,7 & 82,4 & 83,0 & 12,81 & 14,0 \\
\hline 3000 & 32,35 & 1,39 & 24,1 & 230 & 180 & & 0,75 & 81,8 & 80,4 & 82,2 & 79,6 & 80,4 & 13,55 & 14,6 \\
\hline 3000 & 53,00 & 1,01 & 15,6 & 35 & 340 & $\begin{array}{l}696,8 \\
\end{array}$ & 0,60 & 43,6 & 43,3 & 43,7 & 41,7 & 41,8 & 20,49 & 33,9 \\
\hline 3000 & 100,00 & 1,02 & 14,9 & 20 & 345 & 696,8 & 0,60 & 41,8 & 44,6 & 42,0 & 43,0 & 43,4 & 20,80 & 34,0 \\
\hline 3000 & 100,00 & 1,22 & 14,5 & 20 & 345 & 696,8 & 0,50 & 48,2 & 48,5 & 48,5 & 46,0 & 50,2 & 21,45 & 27,7 \\
\hline 3000 & 100,00 & 1,41 & 17,1 & 20 & 340 & & 0,42 & 53,4 & 55,1 & 56,5 & 55,2 & 57,6 & 20,89 & 22,1 \\
\hline 4000 & 24,50 & 1,00 & 22,3 & 440 & 114 & $\begin{array}{l}696,0 \\
\end{array}$ & 0,60 & 85,6 & 81,9 & 88,1 & 84,4 & 81,9 & 10,39 & 6,6 \\
\hline 4000 & 29,25 & 1,12 & 22,2 & 400 & 125 & & 0,63 & 82,8 & 84,7 & 83,4 & 87,9 & 83,7 & 12,2 & 7,3 \\
\hline 4000 & 33,75 & 2,00 & 31,4 & 300 & 160 & & 0,68 & 79,5 & 76,1 & 76,3 & 80,8 & 79,7 & 18,20 & 5,0 \\
\hline 4000 & 32,25 & 1,22 & 19,2 & 350 & 165 & & 0,65 & 69,2 & 73,2 & 66,0 & 68,5 & 66,6 & 14,43 & 7,0 \\
\hline 2000 & 54,00 & 1,06 & 17,3 & 20 & 345 & 695,4 & 0,60 & 64,3 & 63,1 & 67,3 & 71,0 & 73,9 & 12,63 & 29,9 \\
\hline 4000 & 52,00 & 1,37 & 25,8 & 50 & 500 & 696,0 & 0,65 & 46,3 & 39,2 & 34,6 & 34,6 & - & 29,05 & 26,3 \\
\hline 4000 & 99,25 & 1,51 & 21,3 & 30 & 520 & & 0,60 & 39,5 & 41,1 & 41,1 & 40,4 & 39,2 & 30,98 & 22,2 \\
\hline 4000 & $\begin{array}{l}53,00 \\
\end{array}$ & 1,22 & 19,1 & 50 & 530 & & 0,75 & $\begin{array}{l}32,3 \\
\end{array}$ & 33,8 & 34,0 & 36,2 & 37,3 & 28,85 & 29,0 \\
\hline 4000 & 47,50 & 1,08 & 15,7 & 70 & 510 & & 0,80 & 35,0 & 34,7 & 34,5 & 35,1 & 34,1 & 27,61 & 28,3 \\
\hline 4000 & 42,50 & 1,01 & 15,0 & 105 & 500 & & 0,90 & 33,8 & 35,3 & 34,0 & - & - & - & 27,5 \\
\hline
\end{tabular}

Continua 
Conclusão

\begin{tabular}{|c|c|c|c|c|c|c|c|c|c|c|c|c|c|c|}
\hline \multirow{2}{*}{$\begin{array}{c}\omega \\
(\mathrm{rpm})\end{array}$} & \multirow{2}{*}{$\begin{array}{l}|\phi| \\
(\%)\end{array}$} & \multirow[t]{2}{*}{$\lambda$} & \multirow{2}{*}{$\begin{array}{l}\text { Ignição } \\
{ }^{\circ} \mathrm{APMS}\end{array}$} & \multicolumn{4}{|c|}{ Pressão } & \multicolumn{5}{|c|}{ Consumo de etanol $(\mathrm{s} / 100 \mathrm{~g})$ - medidas } & \multirow{2}{*}{$\begin{array}{l}\text { Consumo de } \\
\operatorname{ar}(\mathrm{g} / \mathrm{s})\end{array}$} & \multirow{2}{*}{$\begin{array}{c}\text { Célula de } \\
\text { carga }\end{array}$} \\
\hline & & & & Adm. ${ }^{\diamond}$ & Escape $^{\dagger}$ & Absoluta $^{\ddagger}$ & Caldeira $^{\S}$ & 1 & 2 & 3 & 4 & 5 & & \\
\hline 2000 & 60,75 & 1,11 & 8,5 & 20 & 267 & 695,8 & 0,55 & 13,19 & 25,6 & 73,7 & 73,0 & 77,7 & 70,6 & 74,8 \\
\hline 2000 & 100,00 & 1,11 & 11,0 & 10 & 255 & 695,8 & 0,55 & 13,35 & 26,1 & $\overline{72,0}$ & 72,7 & 76,7 & $\overline{73,1}$ & 72,5 \\
\hline 3000 & 55,75 & 1,31 & 23,0 & 30 & 335 & 695,8 & 0,50 & 21,65 & 27,7 & 47,4 & 47,2 & 48,6 & 54,5 & 52,0 \\
\hline 3000 & 100,00 & 1,24 & 20,0 & 20 & 335 & 695,8 & 0,55 & 21,60 & 29,1 & 49,3 & 51,6 & 49,0 & 50,8 & 48,8 \\
\hline 4000 & 67,00 & 1,47 & 30,1 & 30 & 252 & 695,8 & 0,60 & 30,55 & 24,2 & 42,1 & 42,1 & 43,4 & 40,6 & 42,3 \\
\hline 2000 & 100,00 & 0,86 & 19,6 & 10 & 275 & $\begin{array}{l}695,8 \\
\end{array}$ & 0,45 & 12,79 & 31,0 & 52,1 & 53,1 & 53,1 & 53,4 & 51,7 \\
\hline 3000 & 100,00 & 0,95 & 15,8 & 20 & 365 & 695,4 & 0,67 & 20,71 & 34,6 & 41,2 & 40,8 & 40,5 & 40,0 & 40,0 \\
\hline $3000^{\star}$ & 100,00 & 1,00 & 17,8 & 10 & 150 & 695,4 & 0,75 & 21,53 & 36,5 & 39,2 & 39,2 & 39,7 & 38,4 & 38,8 \\
\hline 920 & 0,00 & 1,00 & 6,5 & & & & & & 0,0 & & & & & \\
\hline $2000^{\star}$ & 100,00 & 0,99 & 25,8 & 10 & 84 & 695,0 & - & 66,6 & 66,0 & 65,7 & - & - & 13,45 & 31,0 \\
\hline
\end{tabular}

$\diamond$ Vácuo em relação à pressão atmosférica, em mmHg.

$\dagger$ Pressão acima da atmosférica, em $\mathrm{mmH}_{2} \mathrm{O}$.

\$ Pressão barométrica, em mmHg.

$\S$ Pressão acima da atmosférica, em Kgf $/ \mathrm{mm}^{2}$.

$\star$ Funcionamento com etanol líquido para comparação justa entre regimes rico e estequiométrico. 
Tabela C.5: Medidas de temperatura e emissões para diversos regimes, operando com etanol vaporizado.

\begin{tabular}{|c|c|c|c|c|c|c|c|c|c|c|c|c|c|c|c|c|c|}
\hline \multirow{2}{*}{$\begin{array}{c}\omega \\
(\mathrm{rpm})\end{array}$} & \multirow{2}{*}{$\begin{array}{l}|\phi| \\
(\%)\end{array}$} & \multirow[t]{2}{*}{$\lambda$} & \multirow{2}{*}{$\begin{array}{l}\text { Ignição } \\
{ }^{\circ} \text { APMS }\end{array}$} & \multirow{2}{*}{$\begin{array}{l}\mathrm{CO} \\
(\%)\end{array}$} & \multirow{2}{*}{$\begin{array}{l}\text { THC } \\
\text { (ppm) }\end{array}$} & \multirow{2}{*}{$\begin{array}{l}\mathrm{CO}_{2} \\
(\%)\end{array}$} & \multirow{2}{*}{$\begin{array}{c}\mathrm{O}_{2} \\
(\%)\end{array}$} & \multirow{2}{*}{$\begin{array}{c}\mathrm{NO}_{x} \\
\text { (ppm) }\end{array}$} & \multicolumn{7}{|c|}{ Temperaturas $\left({ }^{\circ} \mathrm{C}\right)$} & \multicolumn{2}{|c|}{ Caldeira } \\
\hline & & & & & & & & & Adm. & Escape & TBS & TBU & Vap. etanol & Óleo & Venturi & Ent. & Saída \\
\hline 2000 & 24,25 & 1,00 & 21,4 & 0,58 & 180 & 14,3 & 0,61 & 1927 & 54,2 & 554,7 & 24,0 & $\begin{array}{l}9,0 \\
\end{array}$ & 80,1 & 97,1 & 24,9 & 94,0 & 93,1 \\
\hline 2000 & 26,25 & 1,01 & 19,8 & 0,90 & 100 & 13,8 & 0,81 & 1970 & 55,2 & 555,0 & 26,5 & 20,5 & 78,7 & 95,9 & 26,2 & 94,0 & 93,3 \\
\hline 2000 & 41,25 & 1,19 & 17,4 & 0,05 & 92 & 12,5 & 3,77 & 1977 & 57,8 & 542,2 & & & 78,9 & 99,5 & 27,6 & 94,1 & 93,0 \\
\hline 2000 & 57,75 & 1,30 & 18,9 & 0,06 & 96 & 11,5 & 4,74 & 1984 & & 525,5 & 27,5 & 21,5 & 79,4 & 99,9 & 27,4 & 94,0 & $\overline{93,0}$ \\
\hline 2000 & 35,50 & 1,36 & 19,5 & 0,06 & 100 & 11,2 & 5,65 & 345 & 54,8 & 532,4 & 207,0 & 20,0 & 78,8 & 97,2 & 25,8 & 94,2 & 93,3 \\
\hline 2000 & 40,50 & 1,48 & 21,7 & 0,07 & 101 & 10,0 & 6,92 & 132 & 58,1 & 523,5 & & & 78,4 & 98,2 & 28,1 & 93,5 & 92,3 \\
\hline 2000 & 53,00 & 1,01 & 13,9 & 0,37 & 178 & 14,6 & 0,78 & 1962 & 58,9 & 592,1 & 31,5 & 23,0 & 78,0 & 100,7 & 29,8 & 94,2 & 93,0 \\
\hline 2000 & 100,00 & 1,01 & 13,4 & 0,45 & 212 & 14,4 & 0,70 & 1968 & 60,5 & 581,7 & 32,5 & 24,0 & $\overline{77,2}$ & 100,1 & 30,1 & 94,1 & 93,0 \\
\hline 3000 & 24,50 & 1,01 & 26,9 & 0,54 & 24 & 14,4 & 0,70 & 1968 & $\begin{array}{l}58,8 \\
\end{array}$ & 617,8 & 32,5 & 24,5 & 76,7 & 104,4 & 30,7 & 93,9 & 93,3 \\
\hline 3000 & 30,75 & 1,23 & 29,1 & 0,10 & 239 & 12,1 & 4,40 & 1969 & 56,7 & 560,7 & & & 76,7 & 105,3 & 28,9 & 93,8 & 93,2 \\
\hline 3000 & 31,75 & 1,31 & 24,7 & 0,08 & 186 & 11,0 & 5,50 & 750 & 56,1 & 574,0 & 31,5 & 24,0 & 77,0 & 103,8 & 28,6 & 94,1 & 93,3 \\
\hline 3000 & 32,25 & 1,39 & 24,2 & 0,07 & 201 & 10,5 & 6,00 & 100 & 57,9 & 573,2 & & & 75,9 & 103,2 & 29,1 & 93,9 & 93,1 \\
\hline 3000 & 53,00 & 1,01 & 15,6 & 0,27 & 176 & 14,5 & 0,67 & 2004 & 63,8 & 682,7 & 33,0 & 22,5 & 80,1 & 107,1 & 33,7 & 94,1 & 93,0 \\
\hline 3000 & 100,00 & 1,02 & 14,9 & 0,21 & 175 & 14,4 & 1,08 & 2017 & 64,4 & 688,2 & & & 80,0 & 106,9 & 34,4 & 93,8 & 92,5 \\
\hline 3000 & 100,00 & 1,22 & 14,5 & 0,09 & 115 & 12,1 & 4,45 & 85 & 63,6 & $\begin{array}{l}664,0 \\
\end{array}$ & 33,0 & 22,5 & 78,5 & 105,3 & 33,7 & 91,1 & 90,1 \\
\hline 3000 & 100,00 & 1,41 & 17,1 & 0,08 & 154 & 10,6 & 6,43 & 26 & 63,3 & 399,3 & & & 79,3 & 104,4 & 39,6 & 90,6 & 89,8 \\
\hline 4000 & 24,50 & 1,00 & 22,3 & 0,40 & 180 & 14,5 & 0,73 & 1943 & 57,3 & 734,4 & 32,5 & 25,0 & 80,6 & 109,4 & 31,6 & 93,9 & 93,5 \\
\hline 4000 & 29,25 & 1,14 & 22,2 & 0,16 & 142 & 13,0 & 3,10 & 750 & 58,8 & 710,5 & 33,5 & 27,0 & 81,2 & 110,6 & 32,6 & 94,2 & 93,5 \\
\hline 4000 & 33,75 & 2,00 & 31,4 & 0,19 & 590 & 6,8 & 11,5 & 1 & 54,9 & 515,1 & 29,0 & 24,0 & 82,3 & 109,2 & 29,5 & 95,4 & 94,8 \\
\hline 4000 & 32,25 & 1,22 & 19,2 & 0,11 & 563 & 11,8 & 5,0 & 70 & 59,7 & 752,9 & & & 81,2 & 120,0 & 34,5 & 94,6 & 93,9 \\
\hline 2000 & 54,00 & 1,06 & 17,3 & 0,06 & 192 & 14,0 & 1,59 & 1997 & 66,1 & 252,8 & 35,0 & 27,0 & 82,3 & 105,3 & 34,1 & 94,4 & 93,3 \\
\hline 4000 & 52,00 & 1,37 & 25,8 & 0,11 & 193 & 10,7 & 6,12 & 1976 & 65,6 & 541,4 & 39,0 & 27,0 & 84,5 & 116,3 & 38,8 & 97,0 & 96,0 \\
\hline 4000 & 99,25 & 1,51 & 21,3 & 0,10 & 188 & 9,9 & 7,43 & 30 & 68,9 & 555,7 & & & 80,1 & 112,9 & 39,5 & 96,5 & 95,6 \\
\hline 4000 & 52,00 & 1,22 & 19,1 & 0,09 & 243 & 11,8 & 4,39 & 1987 & 71,0 & 567,0 & & & 81,5 & 112,5 & 39,4 & 97,5 & 9,65 \\
\hline 4000 & 48,50 & 1,07 & 15,7 & 0,09 & 117 & 13,5 & 2,60 & 1982 & 70,0 & 611,2 & & & 81,9 & 119,4 & 41,2 & 99,0 & 97,9 \\
\hline 4000 & 42,50 & 1,01 & 15,0 & 0,11 & 117 & 14,3 & 0,50 & 190 & 70,4 & 622,5 & 40,0 & 27,0 & 82,3 & 120,0 & 42,2 & 99,0 & 7,3 \\
\hline
\end{tabular}

Continua 
Conclusão

\begin{tabular}{|c|c|c|c|c|c|c|c|c|c|c|c|c|c|c|c|c|c|}
\hline \multirow{2}{*}{$\begin{array}{c}\omega \\
\text { (rpm) }\end{array}$} & \multirow{2}{*}{$\begin{array}{l}|\boldsymbol{\phi}| \\
(\%)\end{array}$} & \multirow[t]{2}{*}{$\lambda$} & \multirow{2}{*}{$\begin{array}{l}\text { Ignição } \\
{ }^{\circ} \text { APMS }\end{array}$} & \multirow{2}{*}{$\begin{array}{l}\mathrm{CO} \\
(\%)\end{array}$} & \multirow{2}{*}{$\begin{array}{c}\text { THC } \\
(\mathrm{ppm})\end{array}$} & \multirow{2}{*}{$\begin{array}{l}\mathrm{CO}_{2} \\
(\%)\end{array}$} & \multirow{2}{*}{$\begin{array}{c}\mathrm{O}_{2} \\
(\%)\end{array}$} & \multirow{2}{*}{$\begin{array}{l}\mathrm{NO}_{x} \\
(\mathrm{ppm})\end{array}$} & \multicolumn{7}{|c|}{ Temperaturas $\left({ }^{\circ} \mathrm{C}\right)$} & \multicolumn{2}{|c|}{ Caldeira } \\
\hline & & & & & & & & & Adm. & Escape & TBS & TBU & Vap. etanol & Óleo & Venturi & Ent. & Saída \\
\hline 2000 & 60,75 & 1,11 & 8,5 & 0,07 & 249 & 13,3 & 1,99 & 1924 & 61,6 & & 22,0 & 19,0 & 81,6 & 101,2 & 33,0 & 93,9 & 93,0 \\
\hline 2000 & 100,00 & $\overline{1,11}$ & 11,0 & 0,08 & 271 & 13,3 & 2,46 & 1969 & 61,9 & & 22,0 & 19,0 & 81,7 & 100,5 & 32,2 & 93,4 & 92,5 \\
\hline 3000 & 55,75 & 1,31 & 23,0 & 0,08 & 286 & 11,5 & 5,29 & 1973 & 61,4 & & 22,0 & 19,0 & 82,0 & 107,5 & 31,7 & 92,9 & 91,9 \\
\hline 3000 & 100,00 & 1,24 & 20,0 & 0,07 & 196 & 12,0 & 4,20 & 1970 & 61,7 & & 22,0 & 19,0 & 82,2 & 107,8 & 31,9 & 94,0 & 93,0 \\
\hline 4000 & 67,00 & 1,47 & 30,1 & 0,10 & 452 & 9,9 & 7,38 & 492 & 63,8 & & 22,0 & 19,0 & 84,3 & 115,2 & 31,8 & 96,4 & 95,3 \\
\hline 2000 & 100,00 & 0,86 & 19,6 & 6,98 & 63 & 11,1 & 0,19 & 300 & 57,6 & & 22,0 & 19,0 & 80,8 & 96,9 & 28,8 & 96,9 & 93,9 \\
\hline 3000 & 100,00 & 0,95 & 15,8 & 2,05 & 198 & 13,6 & 0,26 & 1960 & 62,9 & & 32,0 & 22,5 & 83,4 & 109,9 & 33,5 & 98,1 & 96,9 \\
\hline 3000 & 100,00 & 1,00 & 17,8 & 0,57 & 95 & 14,4 & 0,45 & 1946 & 59,8 & & 32,0 & 22,5 & 84,1 & 107,4 & 29,9 & 90,6 & 90,3 \\
\hline 920 & 0,00 & 1,00 & 6,5 & 0,16 & 1168 & 14,2 & 1,16 & 0 & 58,2 & & 32,0 & 22,5 & & & & & \\
\hline $3000^{\star}$ & 100,00 & 1,00 & 17,8 & 0,57 & 95 & 14,4 & 0,45 & 1946 & 59,8 & & 32,0 & 22,5 & 84,1 & 107,4 & 29,9 & 90,6 & 90,3 \\
\hline $2000^{\star}$ & 100,00 & 0,99 & 25,8 & 0,16 & 997 & 14,3 & 0,93 & 1989 & 54,0 & 549,2 & 32,0 & 21,0 & - & 80,0 & 34,3 & - & - \\
\hline
\end{tabular}

$\star$ Funcionamento com etanol líquido para comparação justa entre regimes rico e estequiométrico. 
Tabela C.6: Ensaios adicionais com ECU original, para comparação de combinações torque-rotação.

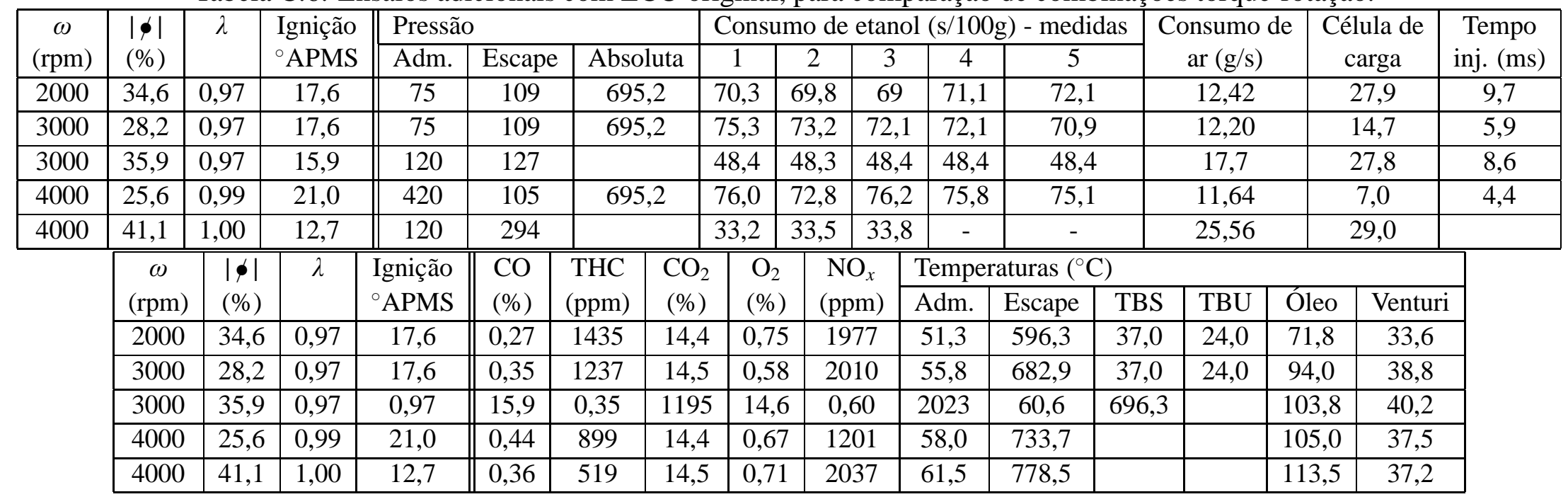

As unidades e referências para medidas de pressão são as mesmas da tabela C.4. 


\title{
Apêndice D
}

\section{Desenhos técnicos}

\begin{abstract}
A seguir são apresentados os desenhos dos conjuntos que foram construídos para permitir a operação do MAPV. As peças apresentam-se como foram fabricadas e não necessariamente como deveriam ser. Tais diferenças devem-se a imprevistos, mudanças no projeto que apresentaramse necessárias durante a fabricação, modo de produção artesanal e disponibilidade de materiais. Os conjuntos mecânicos são: Gerador de vapor; bóia da cuba do gerador; dispositivo de sucção ou Venturi; tubo encamisado e adaptação na válvula com motor de passo.
\end{abstract}





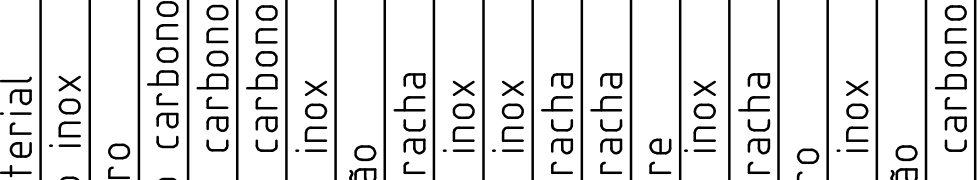

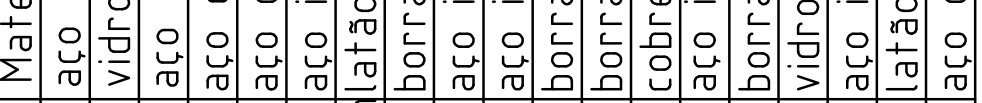

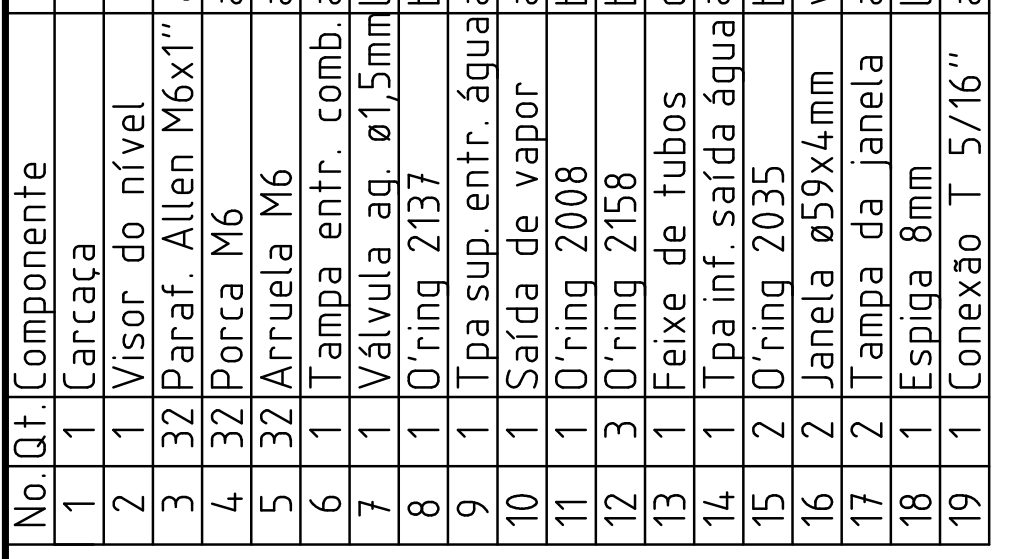

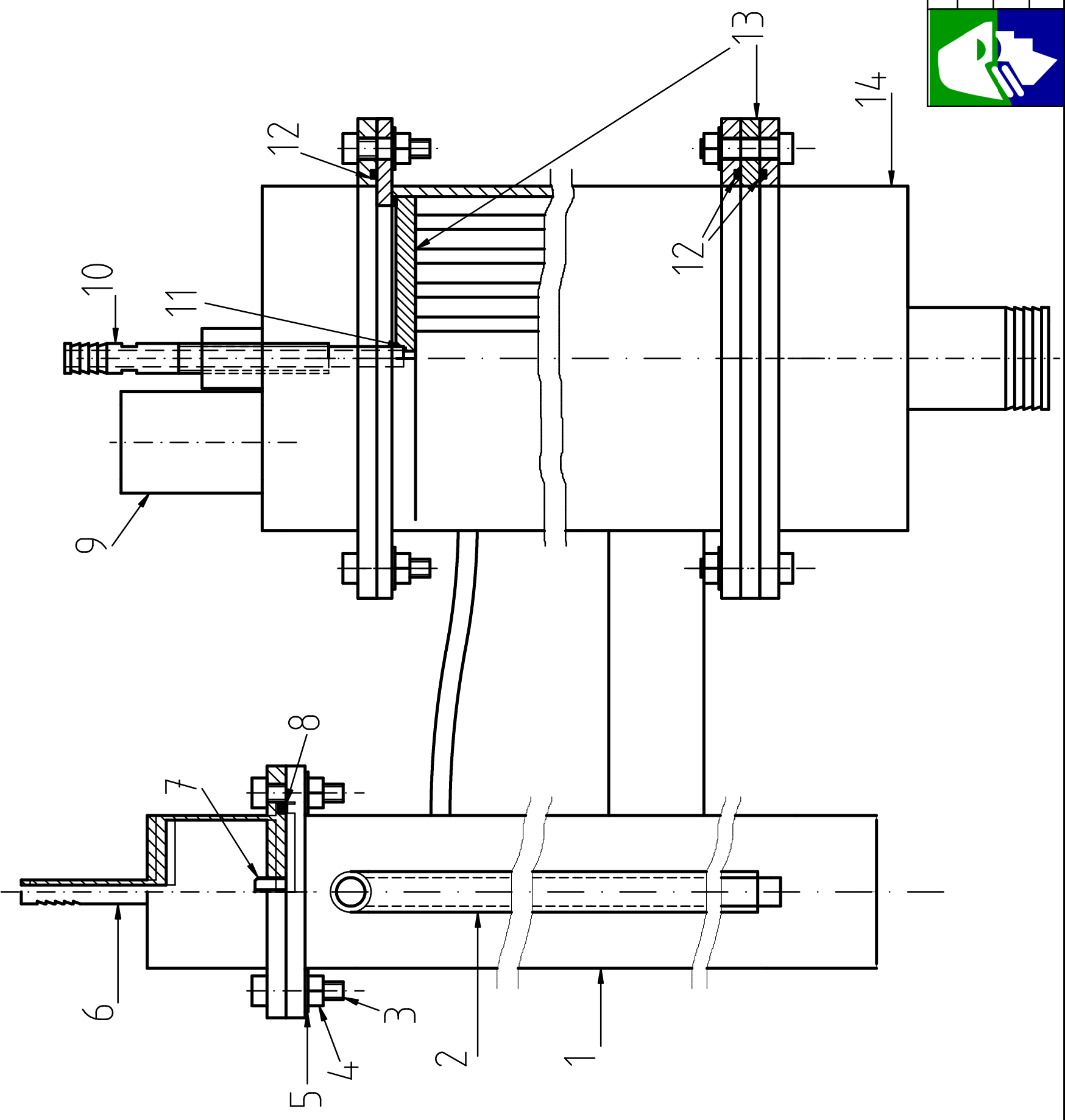




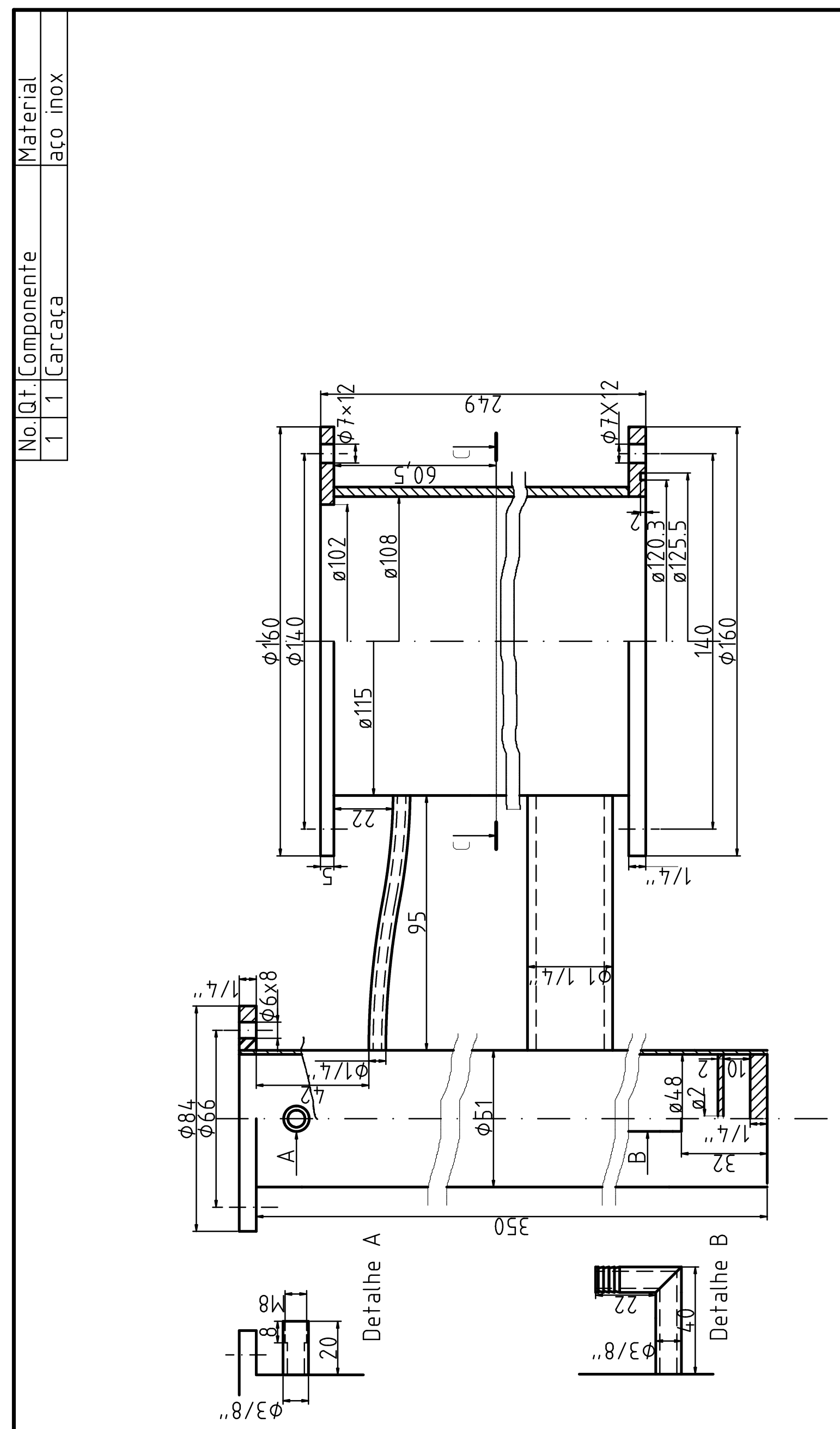


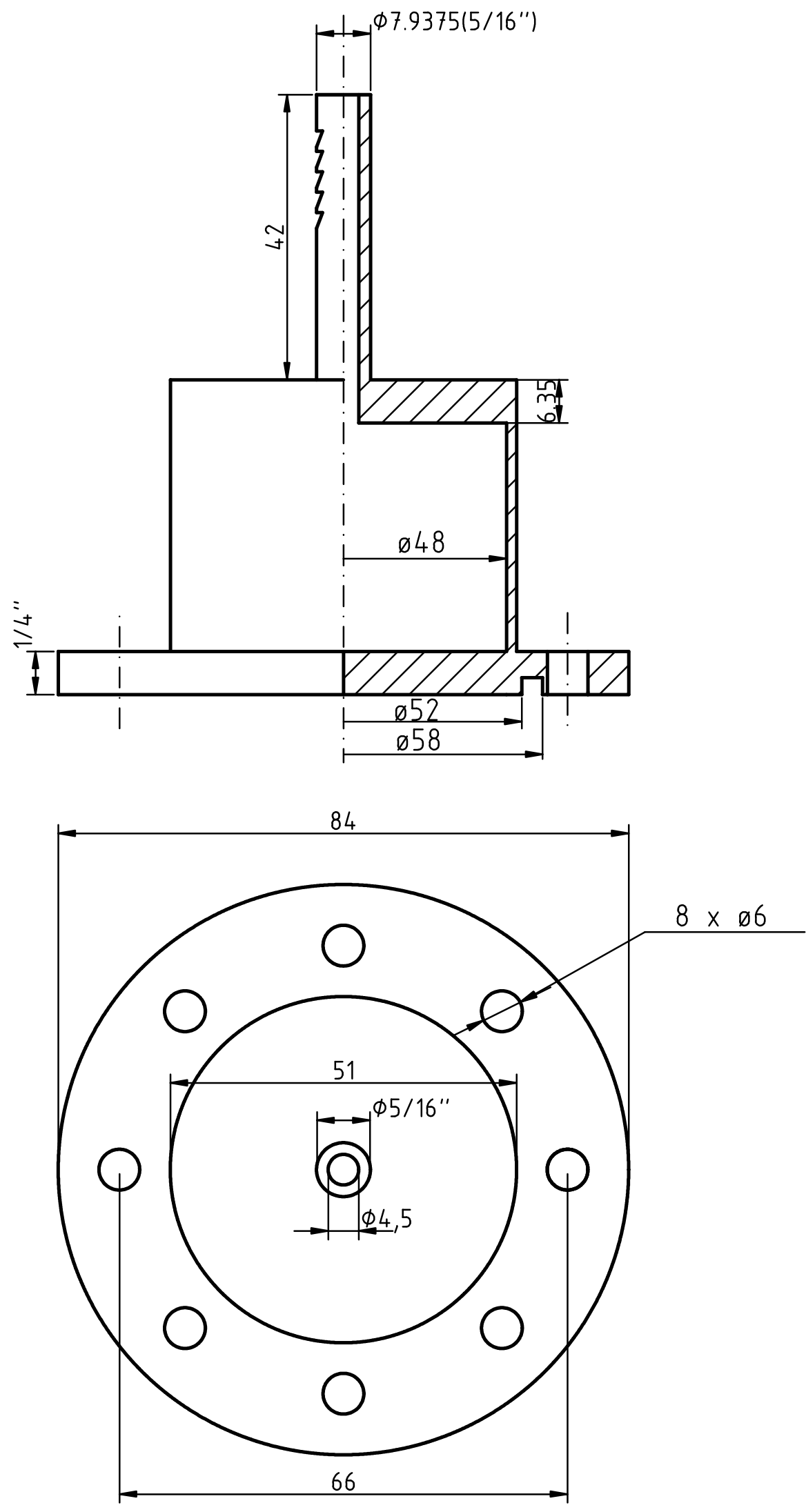

Projeto MAPV

Gerador de vapor (Componente)

Autor: Francisco José Alves 



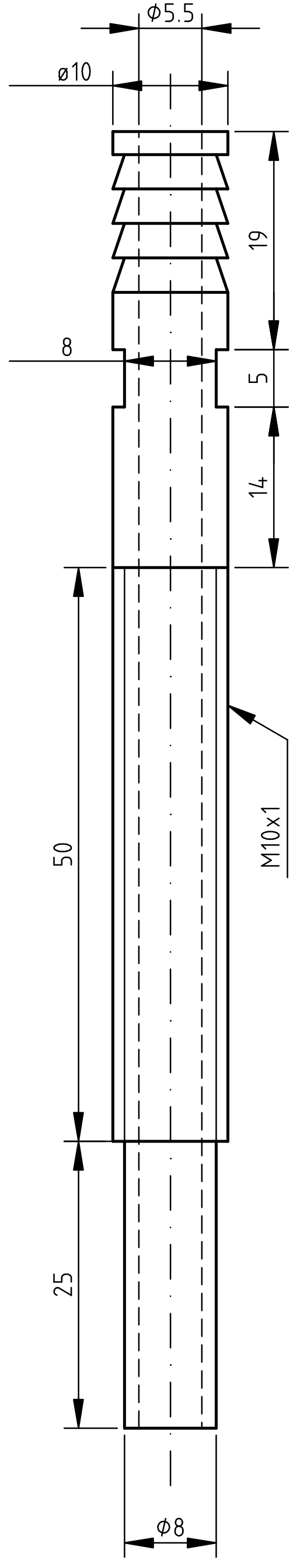





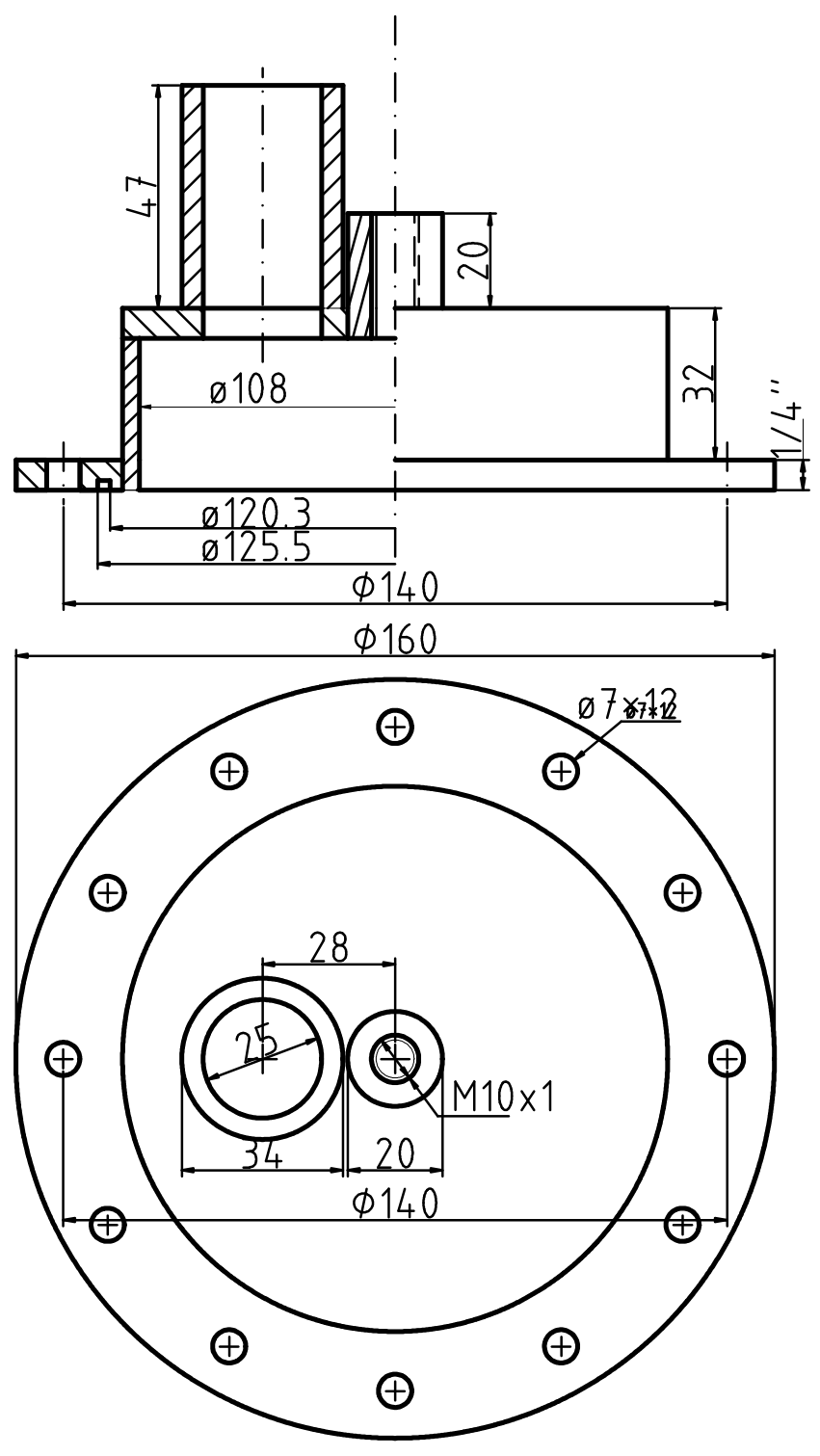

Projeto MAPV

Conjunto 


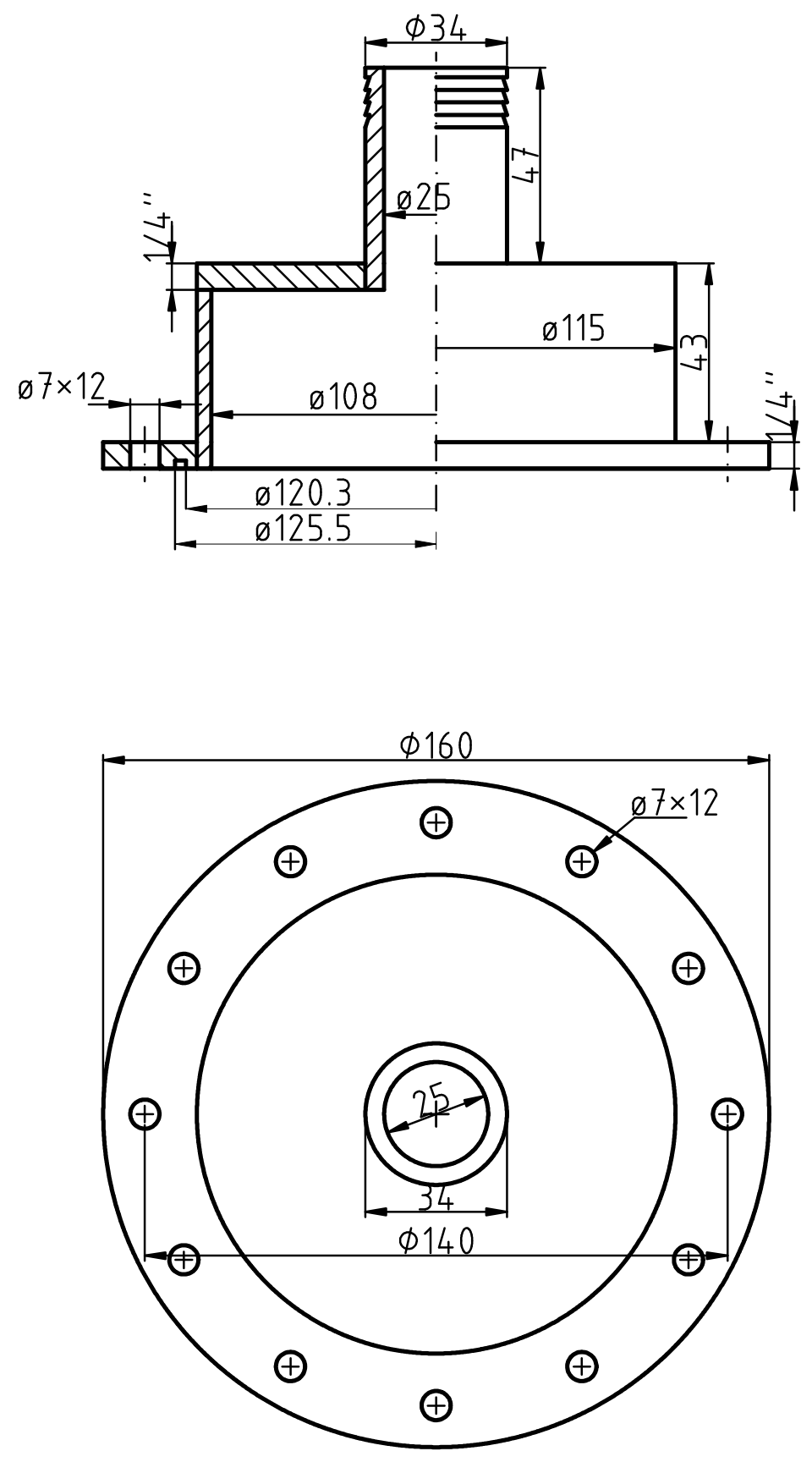



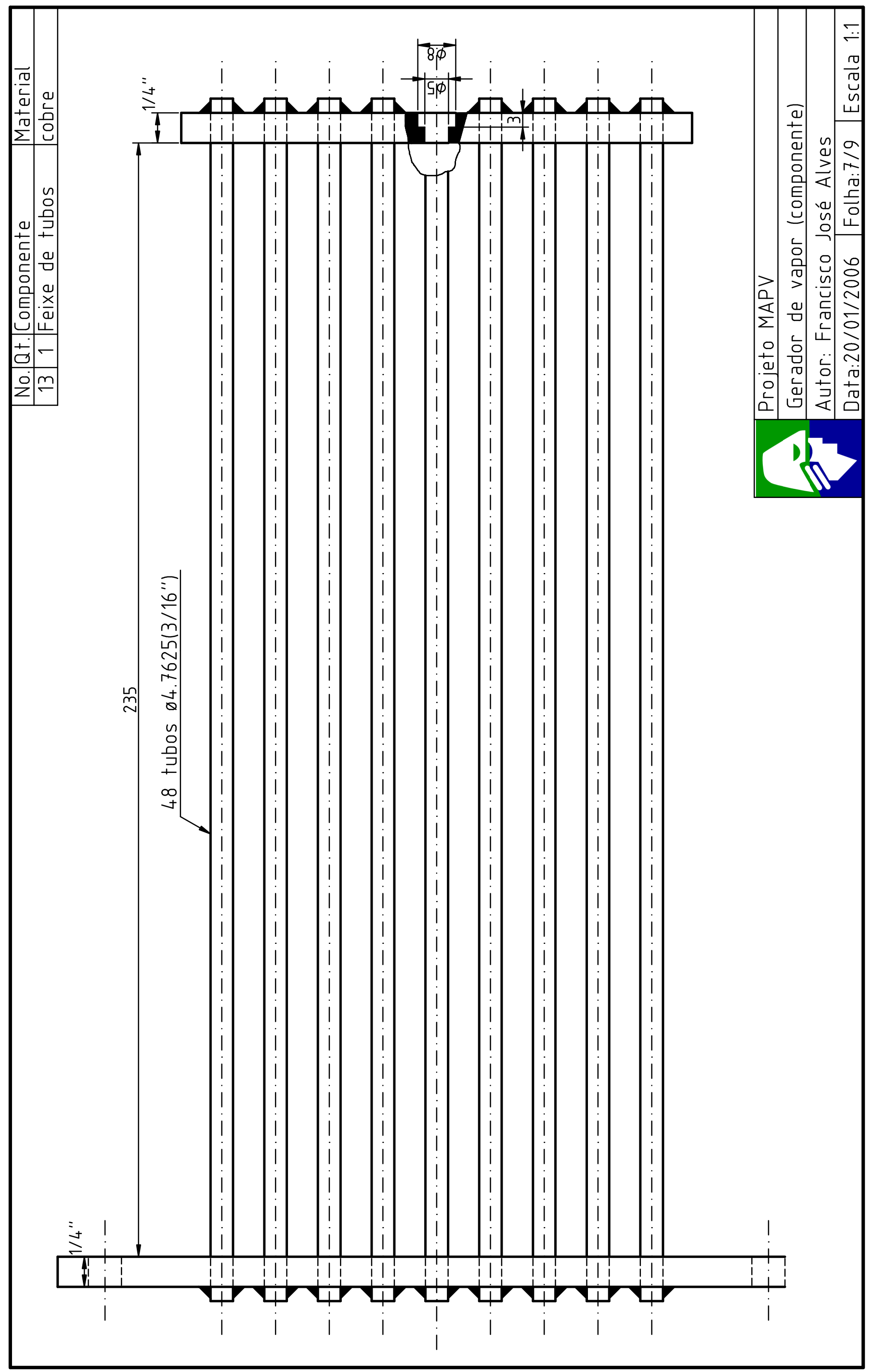





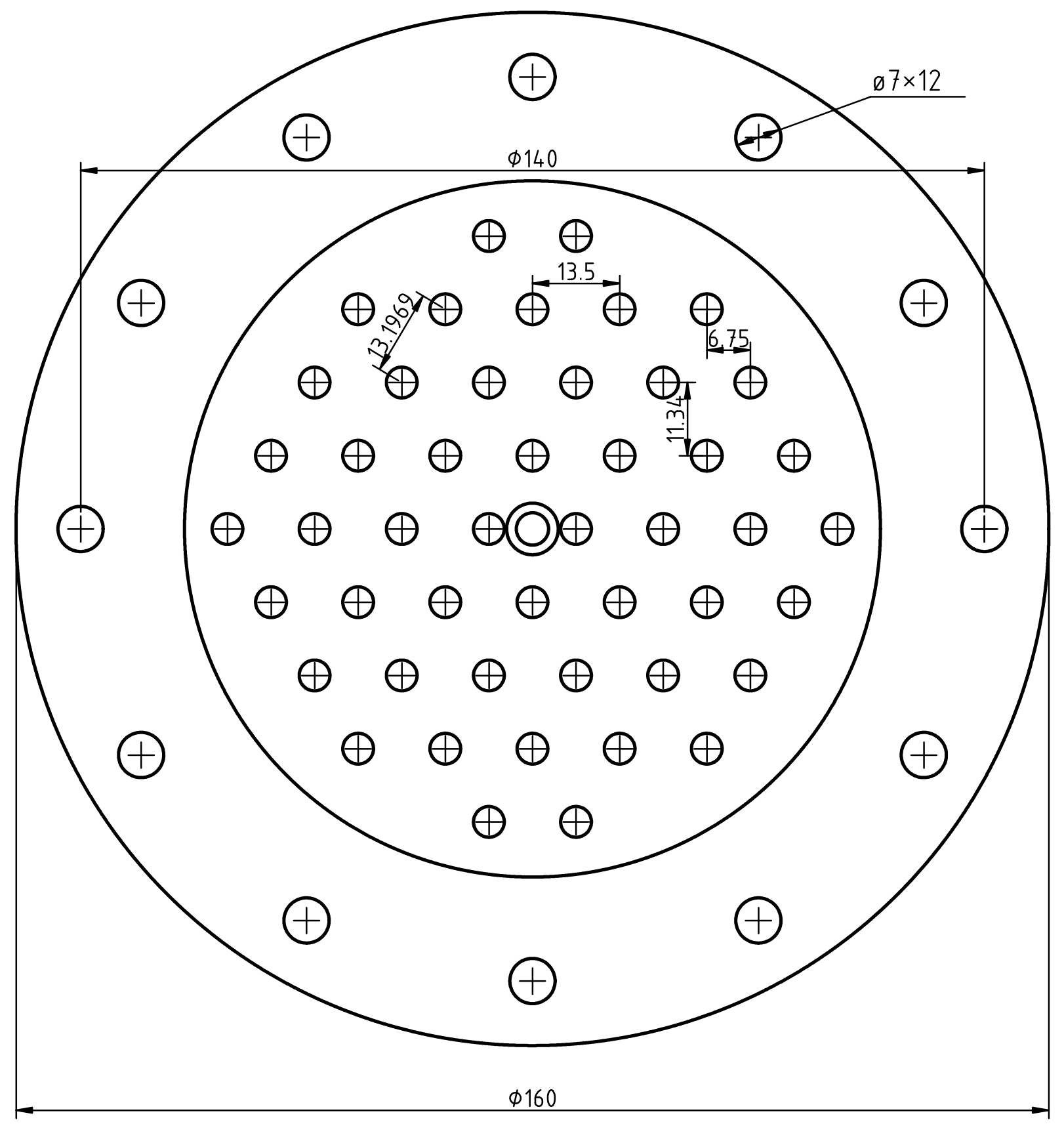

Projeto MAPV

Conjunto 



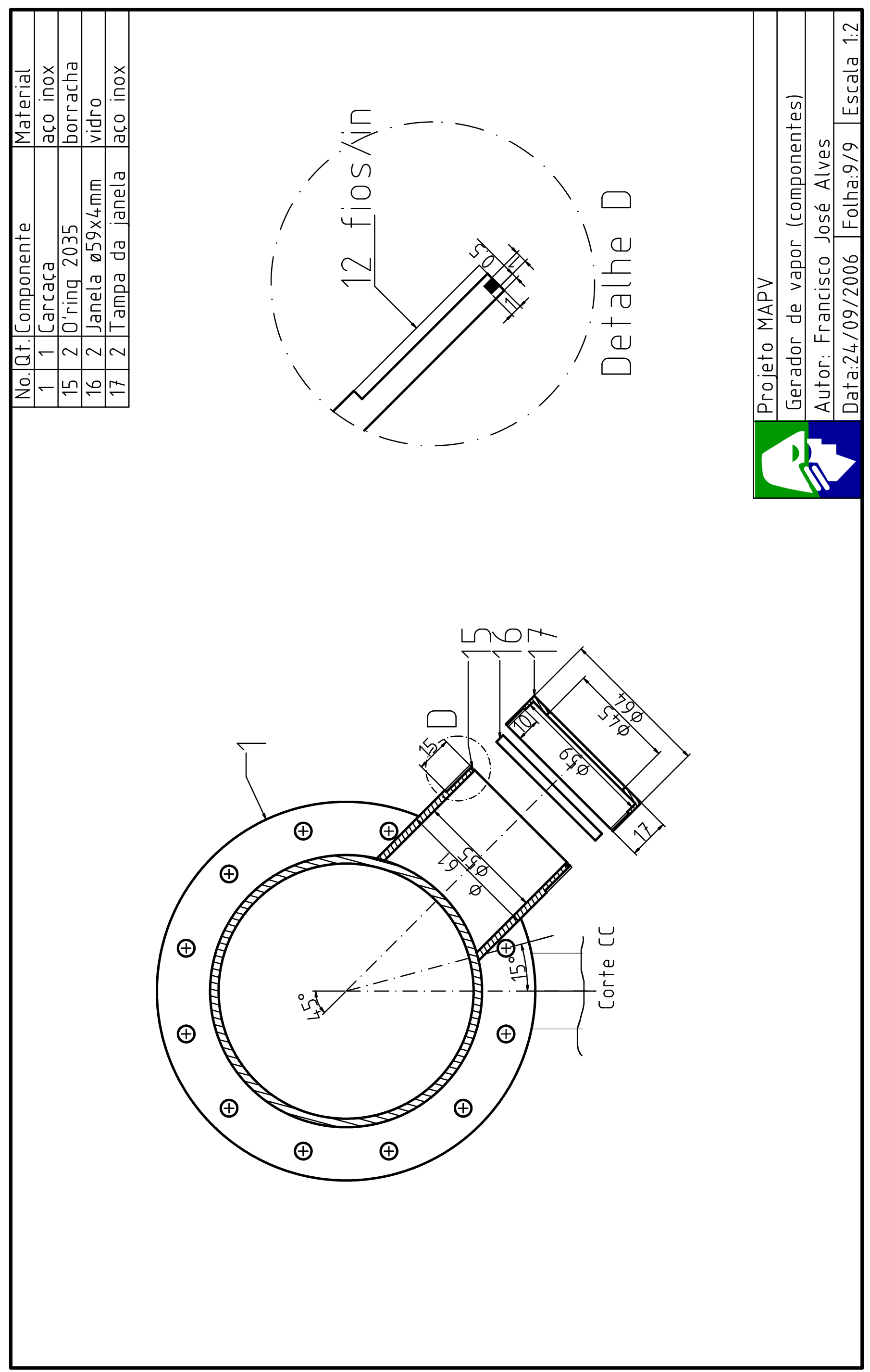





\begin{tabular}{|c|c|l|l|}
\hline No. & Q†. & Componente & Material \\
\hline 1 & 1 & Tampa & nylon \\
\hline 2 & 1 & O'ring 2028 & borracha \\
\hline 3 & 1 & Cогро & nylon \\
\hline 4 & 1 & Guia & aço inox \\
\hline
\end{tabular}
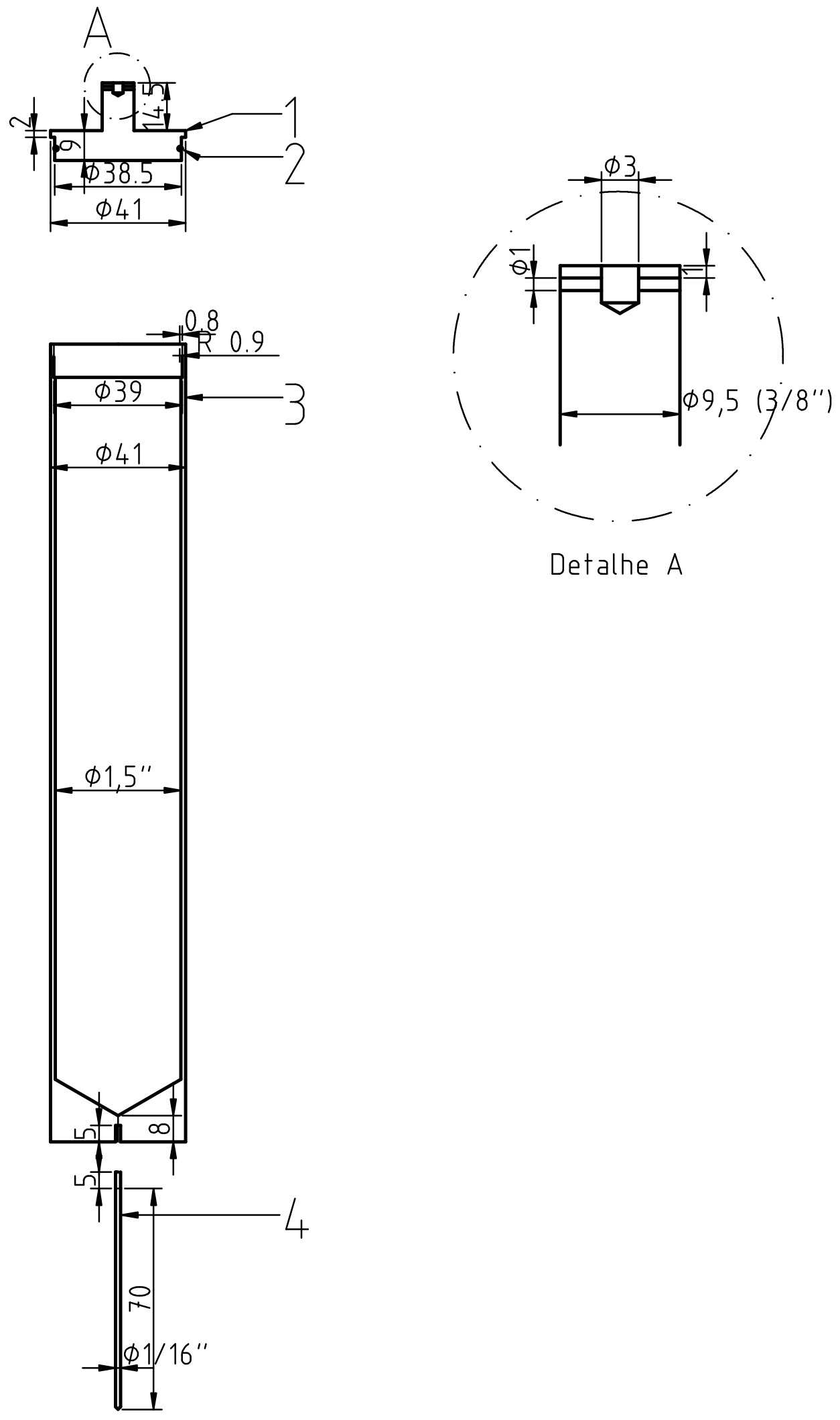

Projeto MAPV

Bóia do gerador de vapor (Conjunto) 



\begin{tabular}{|c|c|l|l|}
\hline No. & Q†. & Componente & Material \\
\hline 1 & 1 & Mang. 2"X30mm & borracha \\
\hline 2 & 1 & O'ring 2137 & borгacha \\
\hline 3 & 1 & O'ring 2139 & borracha \\
\hline 4 & 1 & Bloco & Latão \\
\hline 5 & 1 & Bocal & Latão \\
\hline 6 & 4 & Barra roscada M6 & aço carbono \\
\hline 7 & 8 & Porca M6 & aço carbono \\
\hline 8 & 4 & Arruela M6 & aço carbono \\
\hline 9 & 1 & Corpo de borboleta & $?$ \\
\hline
\end{tabular}

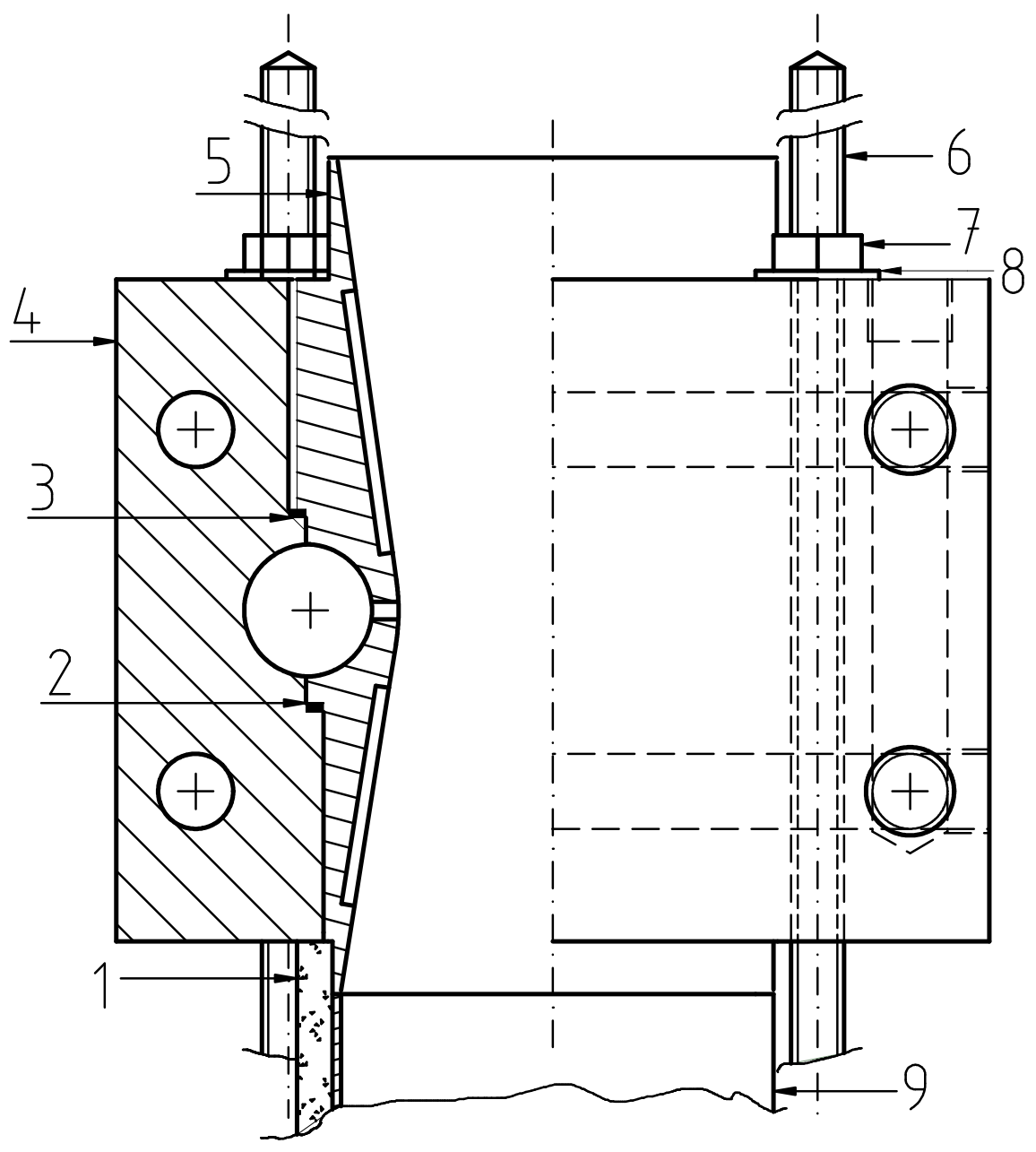





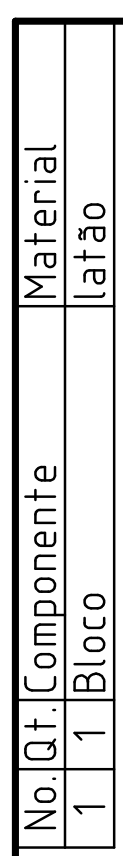

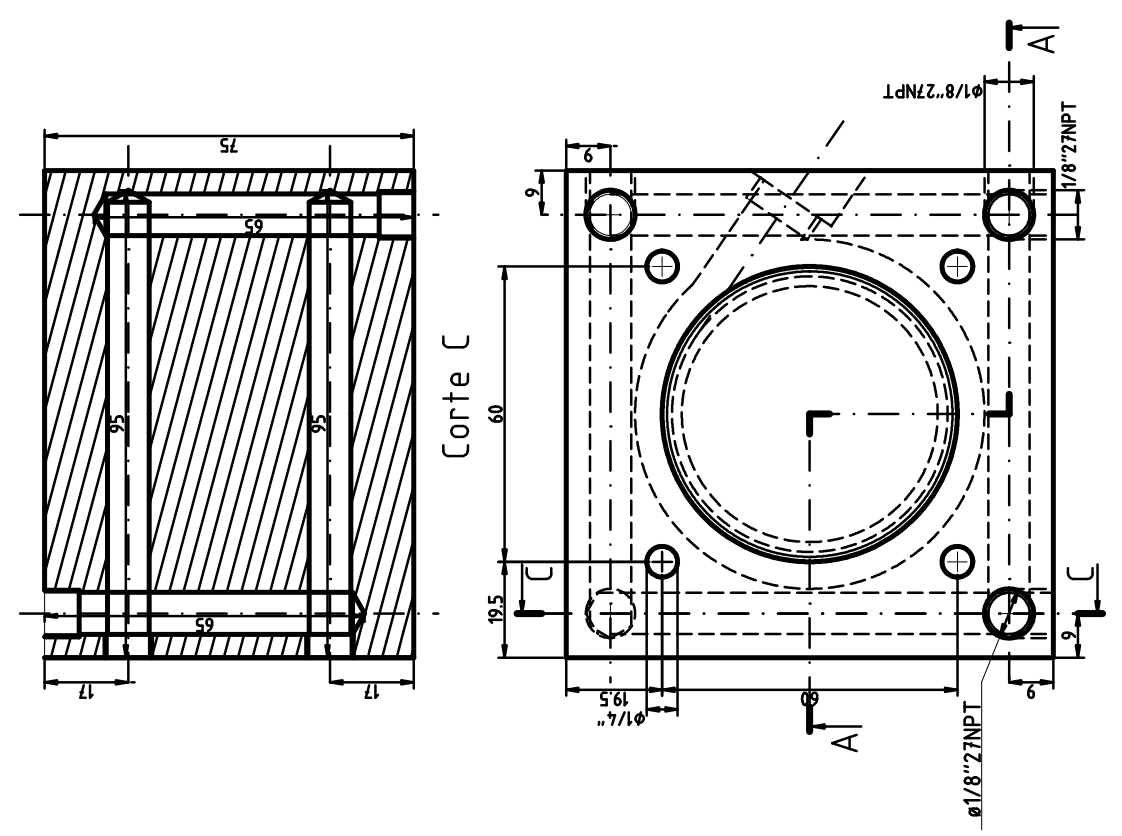

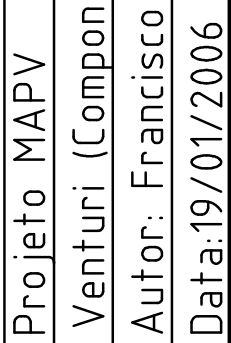

10
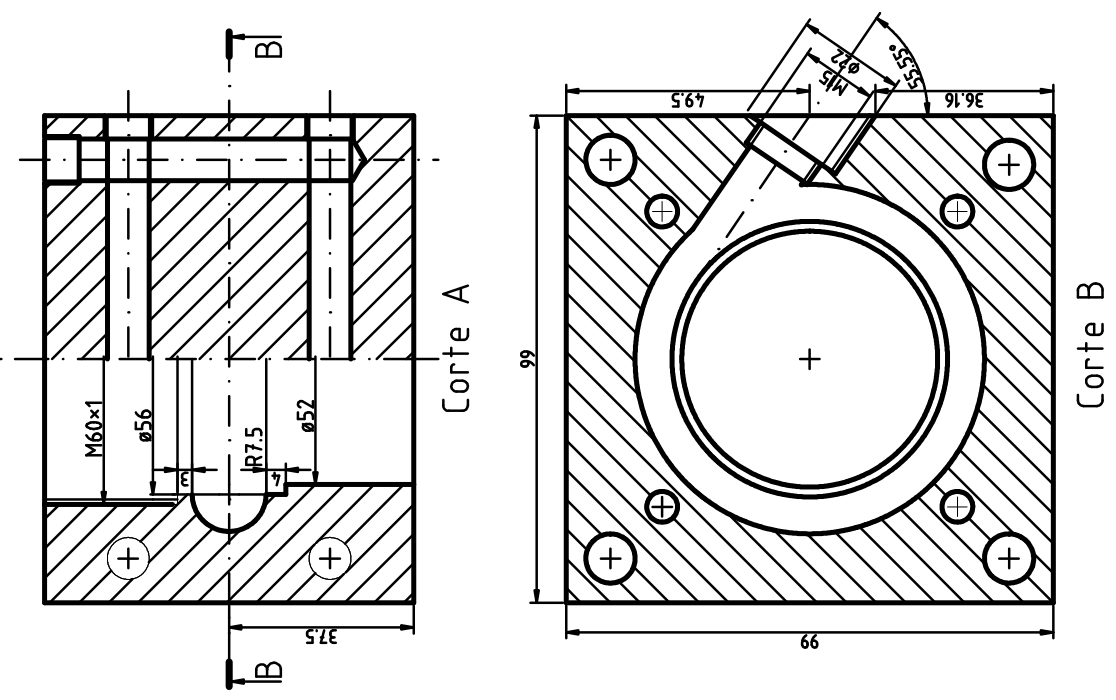



\begin{tabular}{|c|c|l|l|}
\hline No. & Qt. & Componente & Material \\
\hline 1 & 1 & Bocal & latão \\
\hline
\end{tabular}

Preencher com borracha

de silicone não-acético

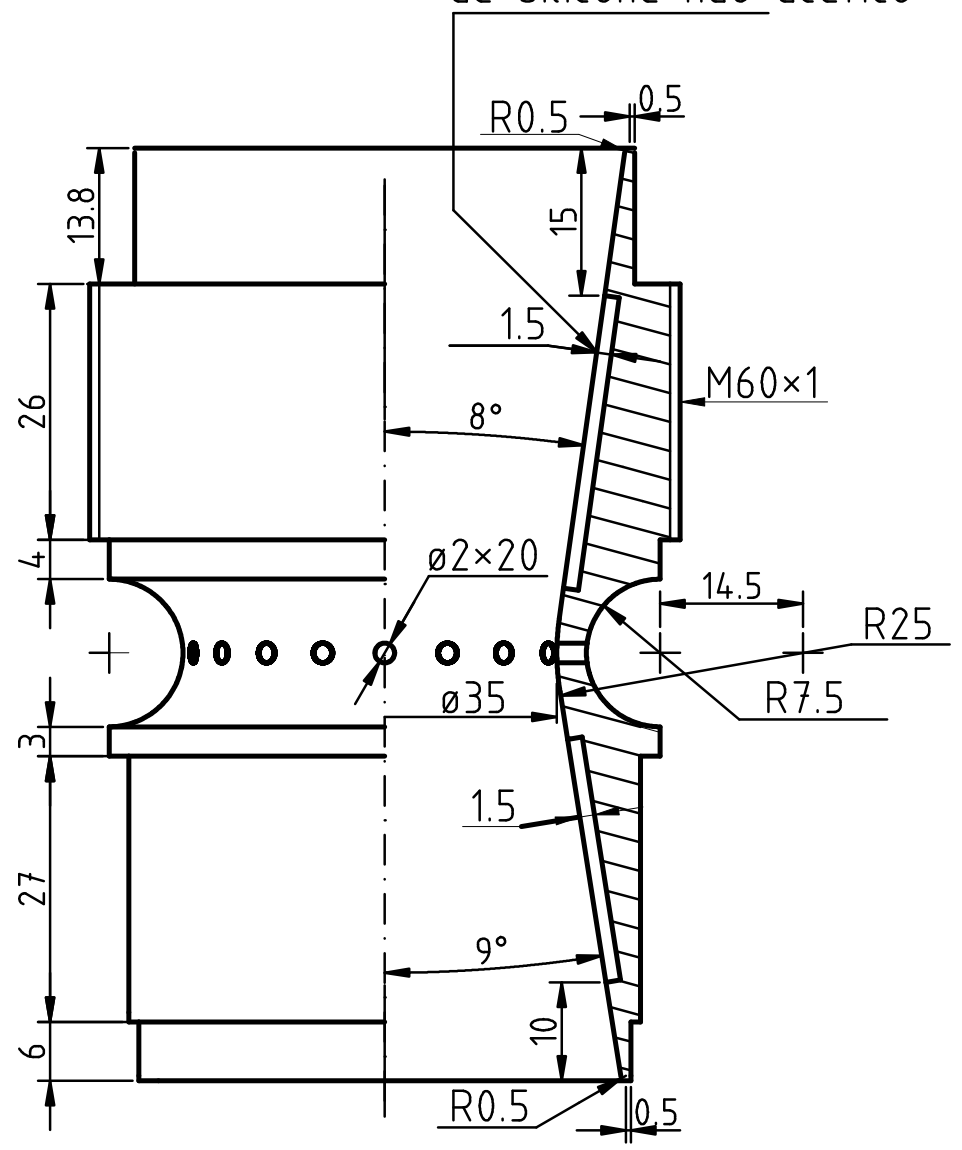

Projeto MAPV

Venturi (Componente)

Autor: Francisco José Alves

Data:19/01/2006 Folha:3/3 $\quad$ Escala 1:1 



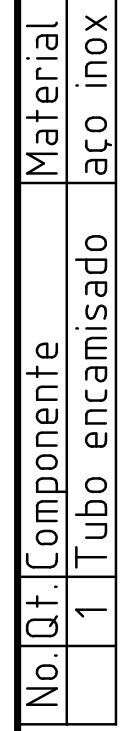
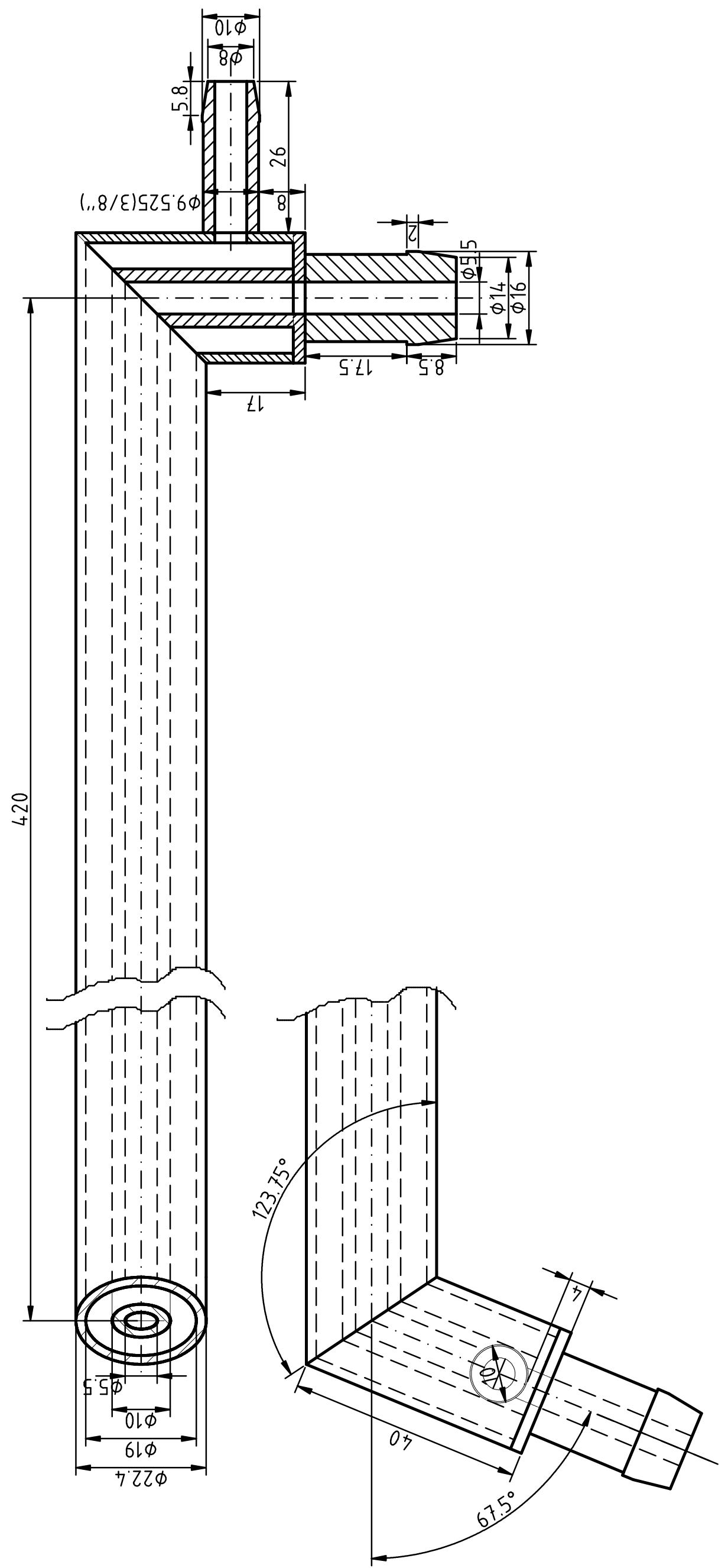



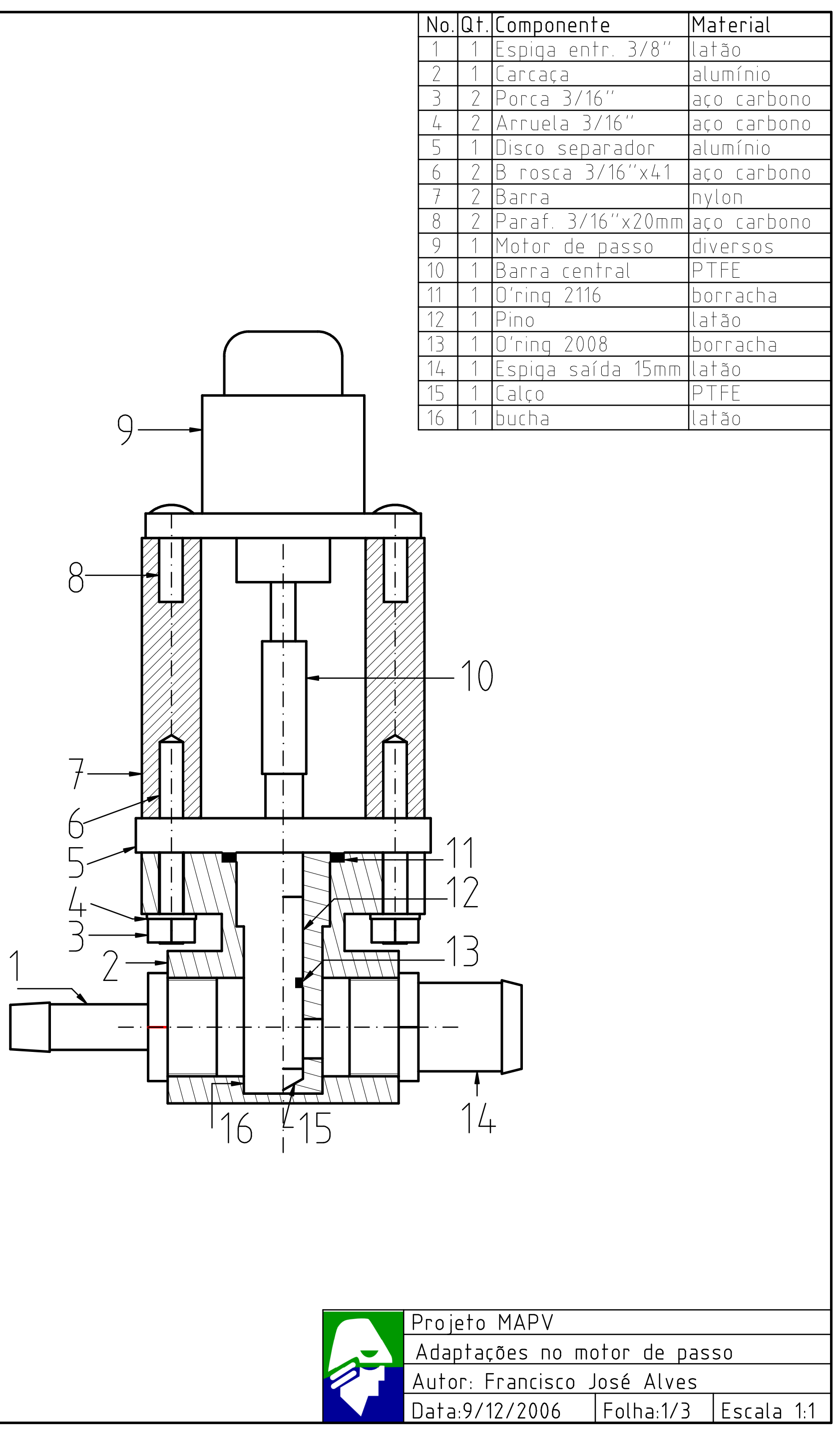





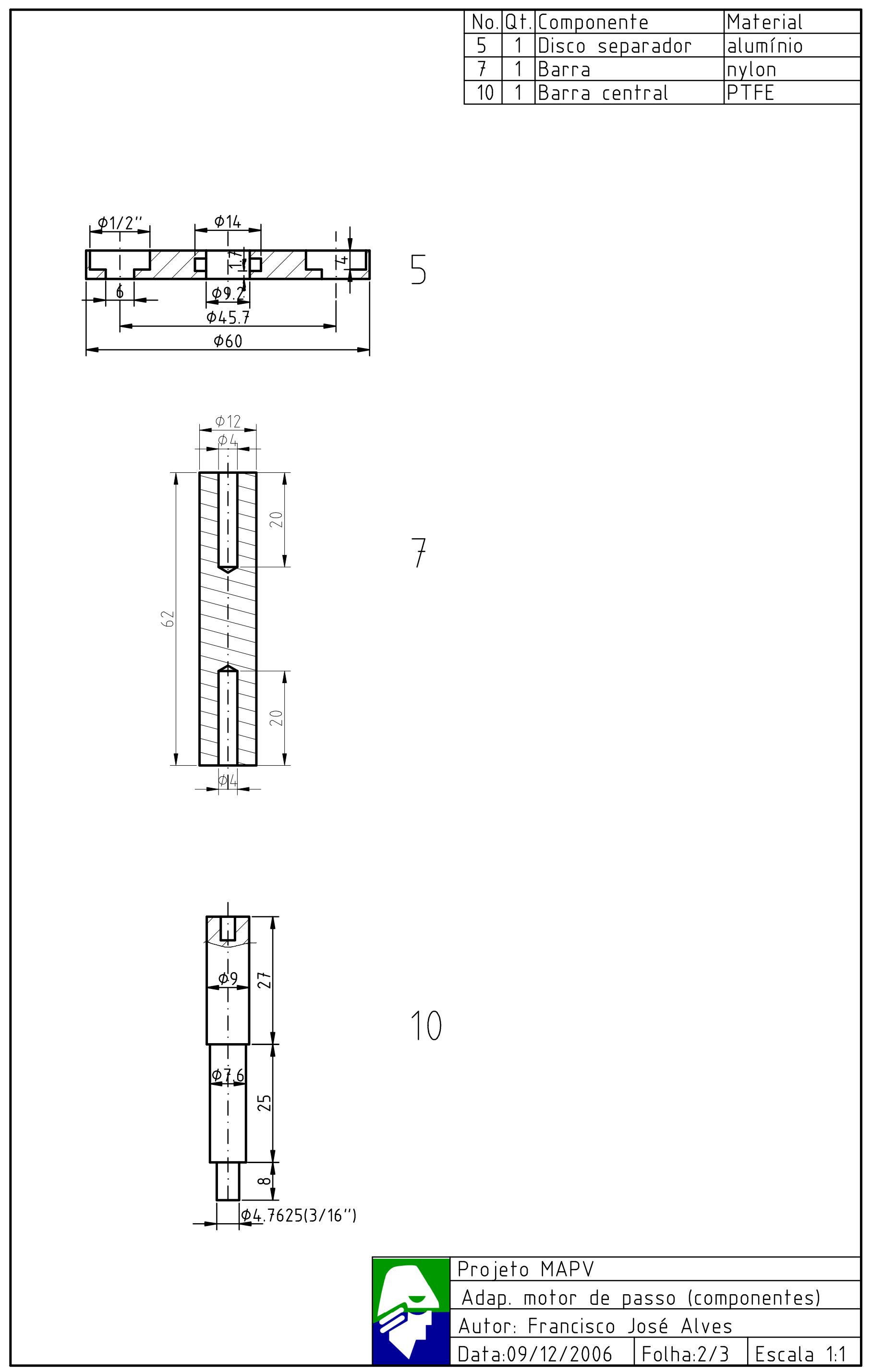





\begin{tabular}{|r|c|l|l|}
\hline No. & Qt. & Componente & Material \\
\hline 12 & 1 & Pino & latão \\
\hline 13 & 1 & O'ring 2008 & borracha \\
\hline 15 & 1 & Calço & PTFE \\
\hline 16 & 1 & Bucha & latão \\
\hline
\end{tabular}
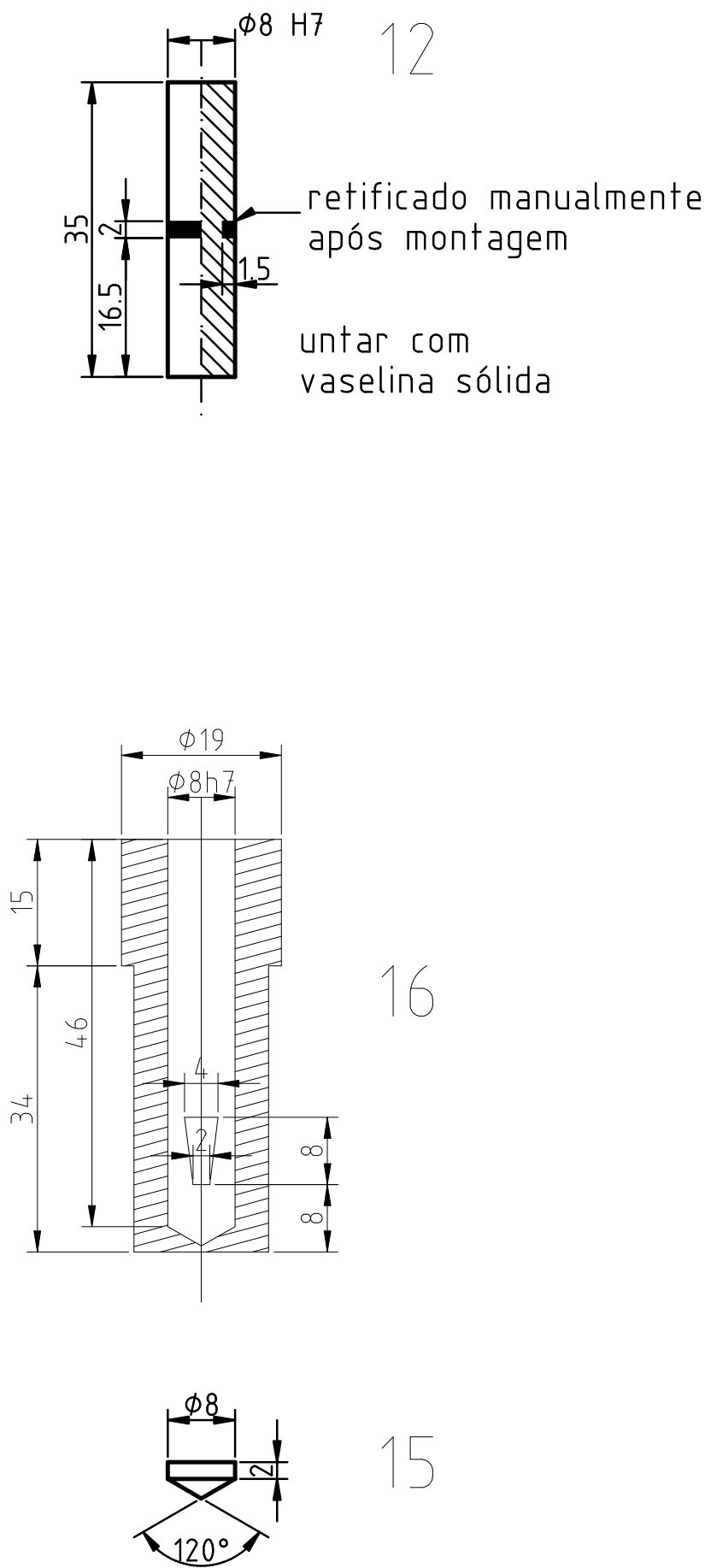

Projeto MAPV

Adap. motor de passo (componentes) 